DEPARTMENT OF THE INTERIOR

ALBERT B. FALL, Secretary

UNited States Geological SURVey George OTIS SMith, Director

\title{
Bulletin 727
}

\section{POTASH IN THE GREENSANDS OF NEW JERSEY}

BY

GEORGE ROGERS MANSFIELD

Work done in cooperation with the Department of Conservation and Development of New Jersey

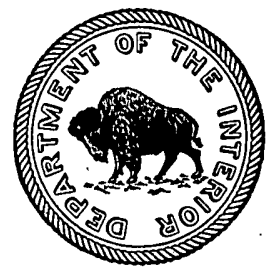

WASHINGTON

GOVERNMENT PRINTING OFFICE

1922 
ADDITIONAL COPIES

OF THIS PUBLICATION MAY BE PROCURED FROM THE SUPERINTENDENT OF DOCUMENTS GOVERNMENT PRINTING OFFICB WASHINGTON, D. C.

AT

50 CENTS PER COPY 


\section{CONTENTS.}

Page.

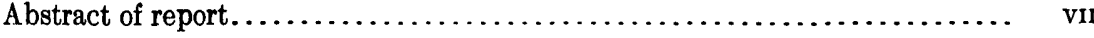

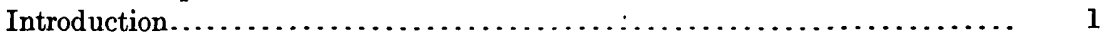

Purpose and scope of investigation........................... 1

Acknowledgments...................................... 2

Location of deposits....................................... 4

Transportation facilities.................................... 4

General features of the deposits............................... 5

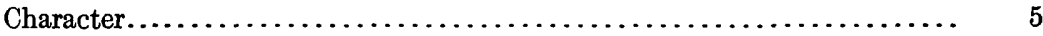

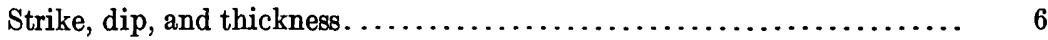

Local names.............................................. 6

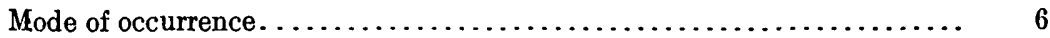

Glauconite-bearing and associated formations....................... 7

Age and general sequence.................................... 7

Raritan formation........................................ 8

Magothy formation........................................... 8

Merchantville clay........................................ 8

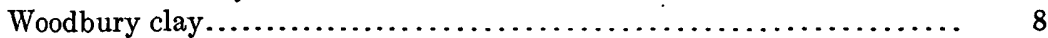

Englishtown sand.......................................... 9

Marshalltown formation. .................................... 9

Wenonah and Mount Laurel sands.......................... 9

Navesink marl........................................ 10

Redbank sand, including Tinton sand member................ 10

Hornerstown marl........................................ 11

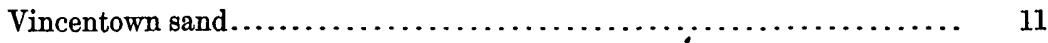

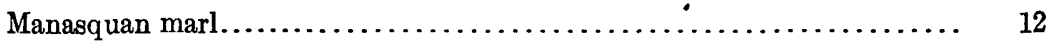

Tertiary and Quaternary formations........................... 12

Commercially important formations........................... 12

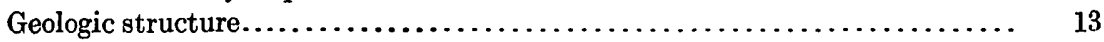

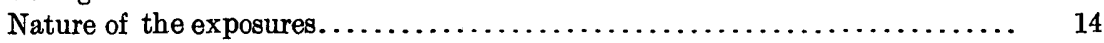

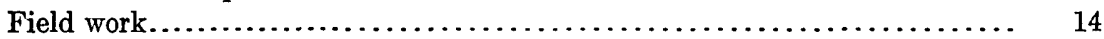

Selection of areas for drilling $\ldots \ldots \ldots \ldots \ldots \ldots \ldots \ldots \ldots \ldots \ldots \ldots \ldots, 14$

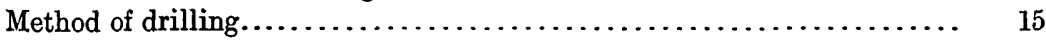

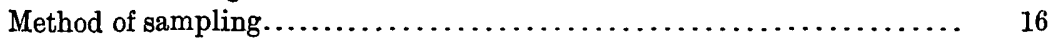

Disadvantages of wet method................................ 18

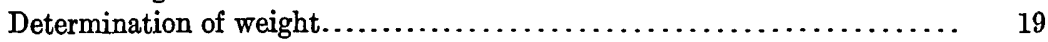

Collection of well data.................................... 20

Other field data.............................................. 20

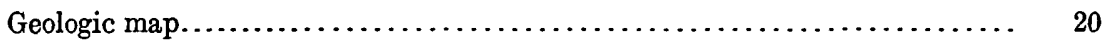

Results of field work. ....................................... 21

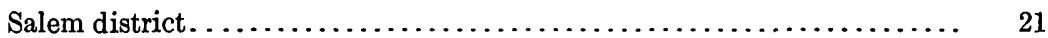

Selection and location of sites................................ 21

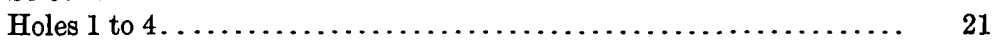

Well data. . . . . . . . . . . . . . . . . .

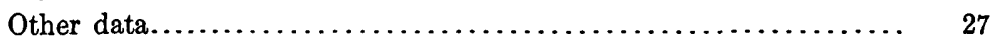

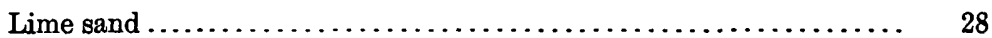

Estimates of tonnage and value........................... 29

Utilization of the deposits................................ 29 
Results of field work-Continued. $\quad$ Page.

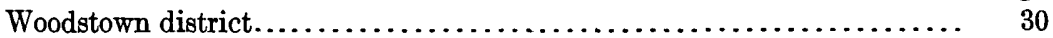

Selection and location of sites........................ 30

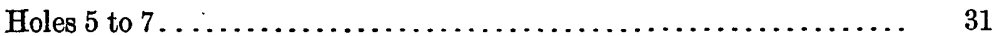

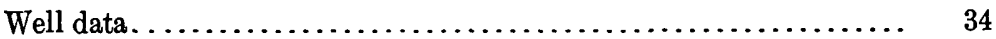

Other data $\ldots \ldots \ldots \ldots \ldots \ldots \ldots \ldots \ldots \ldots \ldots \ldots \ldots \ldots \ldots \ldots \ldots \ldots \ldots$

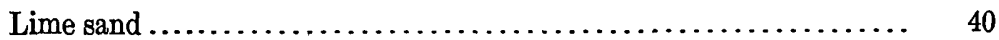

Estimates of tonnage and value $\ldots \ldots \ldots \ldots \ldots \ldots \ldots \ldots \ldots \ldots \ldots, 40$

Utilization of the deposits............................ 41

Mullica Hill................................... 41

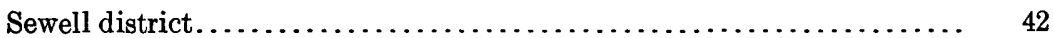

Edwards Run.................................... 42

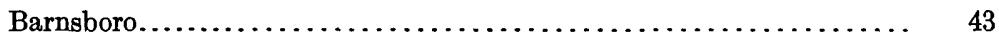

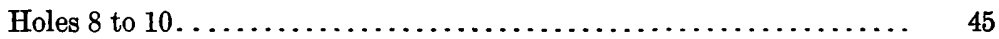

Borings of West Jersey Marl \& Transportation Co ............... 51

Sewell marl pit.................................... 51

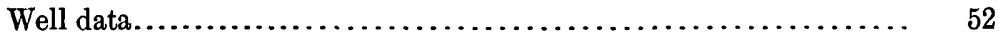

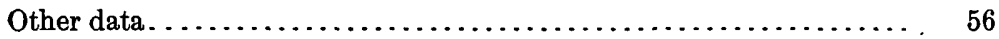

Lime sand $\ldots \ldots \ldots \ldots \ldots \ldots \ldots \ldots \ldots \ldots \ldots \ldots \ldots \ldots \ldots \ldots \ldots \ldots \ldots$

Estimates of tonnage and value...................... 57

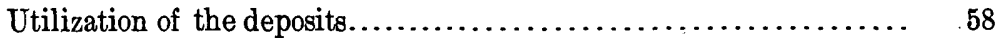

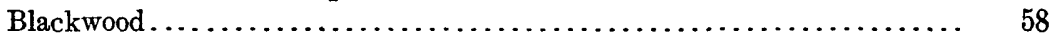

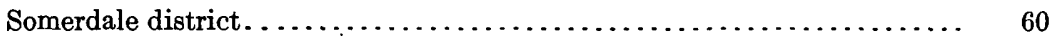

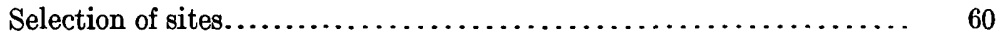

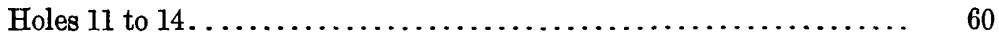

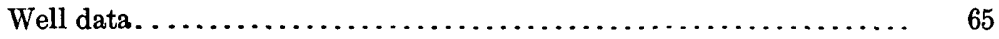

Other data. . . . . . . .

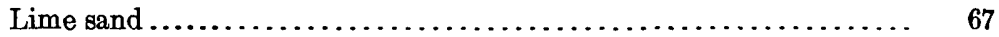

Estimates of tonnage and value $\ldots \ldots \ldots \ldots \ldots \ldots \ldots \ldots \ldots \ldots \ldots \ldots$

Utilization of the deposits. . . . . . . . . . . . . . . . . . 67

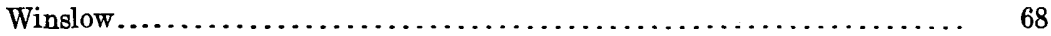

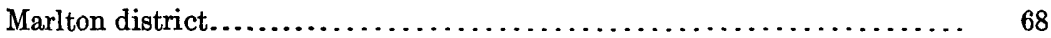

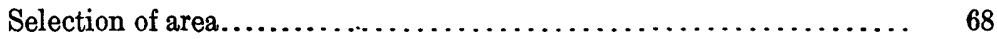

Holes 15 and $16 \ldots \ldots \ldots \ldots \ldots \ldots \ldots \ldots \ldots \ldots \ldots \ldots \ldots \ldots \ldots \ldots$

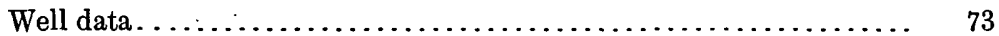

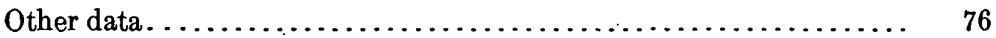

Atlantic Potash Co.'s pit. . . . . . . . . . . . . . 76

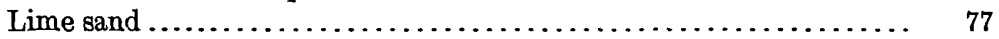

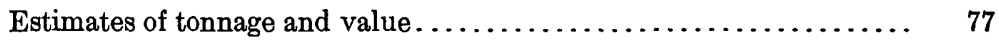

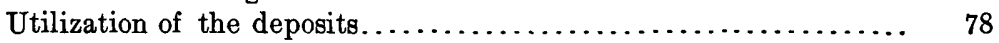

Medford district. . . . . . . . . . . . . . . .

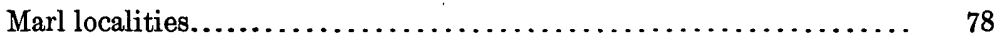

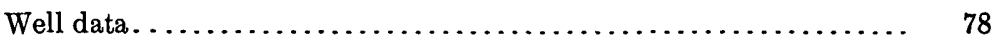

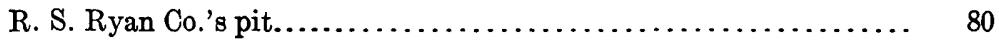

Lime sand $\ldots \ldots \ldots \ldots \ldots \ldots \ldots \ldots \ldots \ldots \ldots \ldots \ldots \ldots \ldots \ldots \ldots \ldots \ldots$

Vincentown.$\ldots \ldots \ldots \ldots \ldots \ldots \ldots \ldots \ldots \ldots \ldots \ldots \ldots \ldots \ldots \ldots \ldots \ldots \ldots \ldots$

Well data $\ldots \ldots \ldots \ldots \ldots \ldots \ldots \ldots \ldots \ldots \ldots \ldots \ldots \ldots \ldots \ldots \ldots \ldots \ldots \ldots$

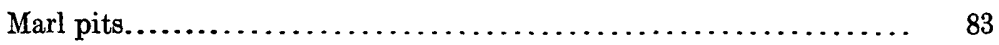

Lime sand $\ldots \ldots \ldots \ldots \ldots \ldots \ldots \ldots \ldots \ldots \ldots \ldots \ldots \ldots \ldots \ldots \ldots \ldots$

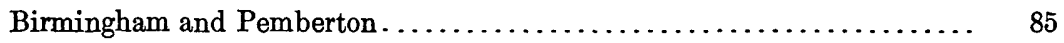

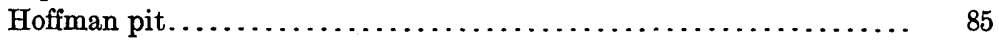

Pits of Norcross \& Edmunds Co........................ 86

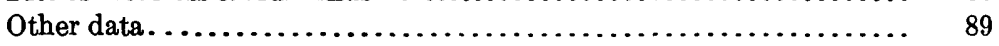

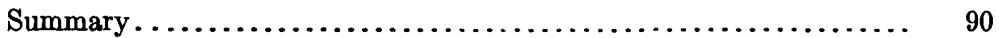


Results of field work-Continued.

Other areas............................................... 90

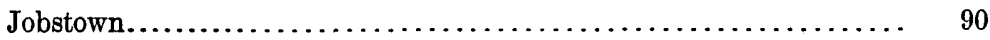

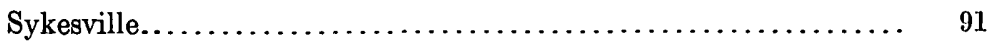

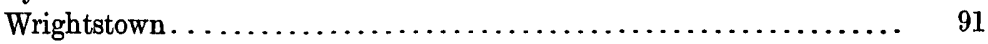

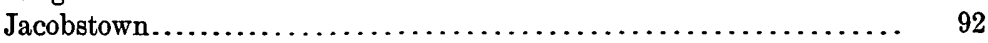

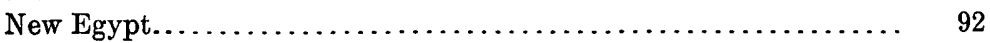

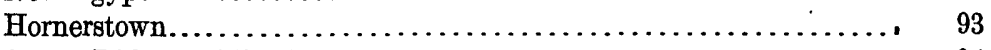

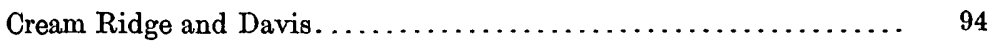

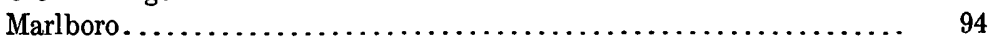

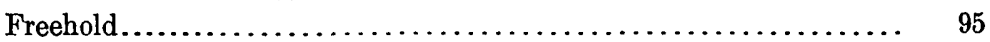

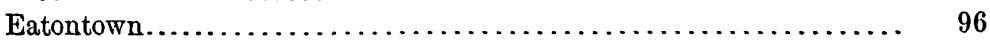

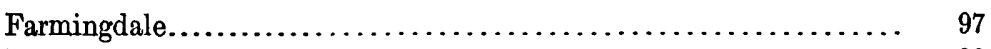

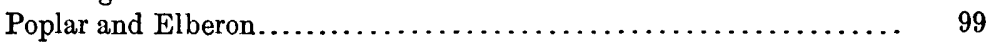

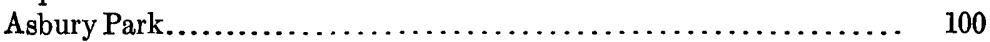

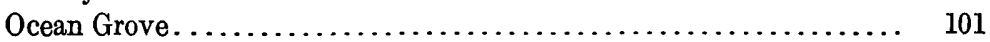

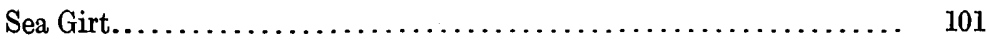

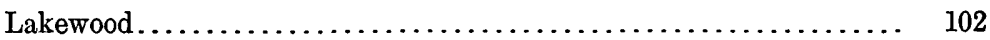

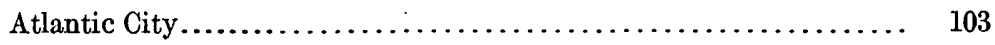

Summary of field data and estimates $\ldots \ldots \ldots \ldots \ldots \ldots \ldots \ldots \ldots \ldots \ldots, 103$

General estimates for entire marl belt.......................... 106

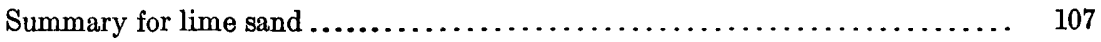

Commercial development.................................... 107

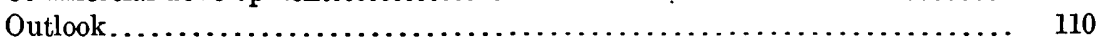

Availability of potash in greensand $\ldots \ldots \ldots \ldots \ldots \ldots \ldots \ldots \ldots \ldots \ldots \ldots, 113$

Earlier views on agricultural value............................ 115

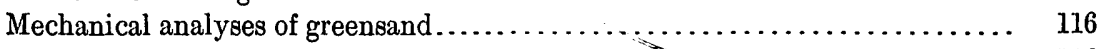

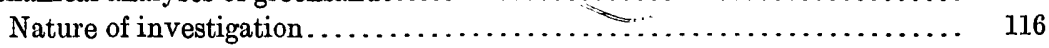

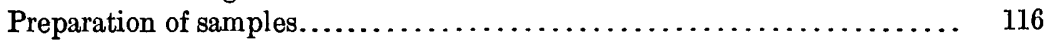

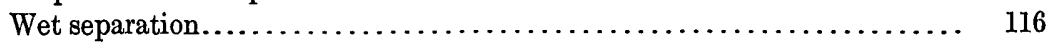

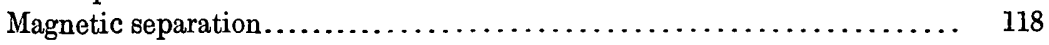

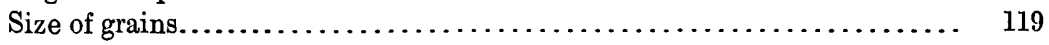

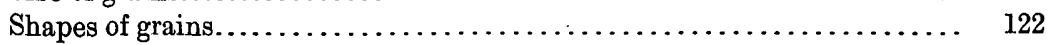

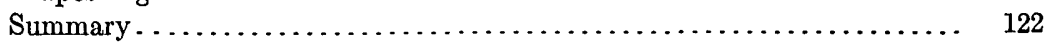

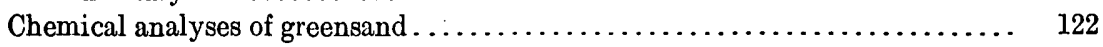

Character and number of analyses........................... 122

Composition of greensand ................................. 123

Composition of products of wet separation...................... 125

Potash content of the fines.................................. 125

Composition of glauconite................................... 127

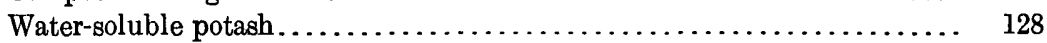

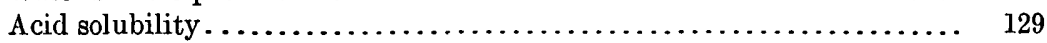

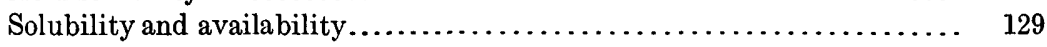

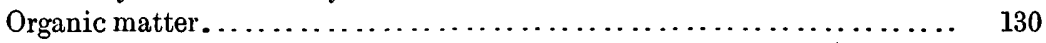

Phosphoric acid and lime................................ 130

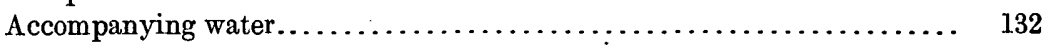

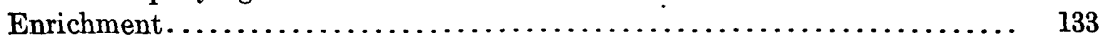

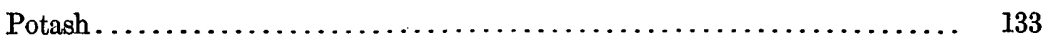

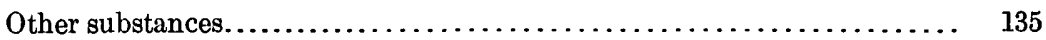

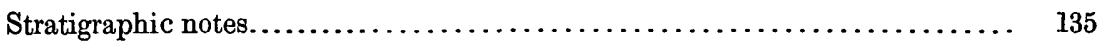

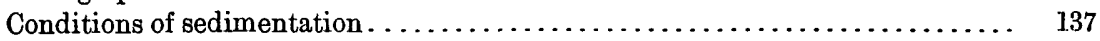

Nature and origin of glauconite.............................. 138

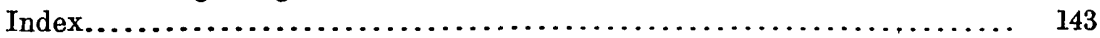




\section{ILLUSTRATIONS.}

Page.

Plate I. Geologic map of New Jersey greensand beds, Salem to Blackwood. In pocket.

II. Geologic map of New Jersey greensand beds, Laurel Springs to Cream Ridge.................................. In pocket.

III. Geologic map of New Jersey greensand beds, Imlaystown to Sandy

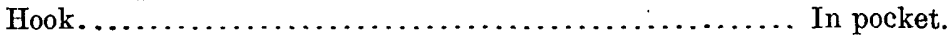

IV. Photomicrographs of glauconite. ......................... $\quad 6$

V. $A$, Generalized cross section of Cretaceous and Tertiary formations southeast of Trenton; $B$, Section southeastward from Camden.....

VI. $A$, General view of William Hoffman's marl pit; $B$, Shell bed at Mullica Hill.......................................

VII. $A$, Drilling operations at Woodstown; $B$, Sampling trough in use at Elmwood Road..................................... 16

VIII. $A$, Pit of Atlantic Potash Corporation near Marlton; $B$, Sewell marl

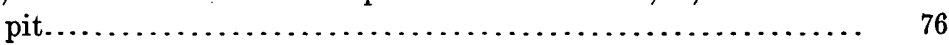

IX. $A$, Exposure at R. S. Ryan Co.'s marl pit; $B$, William Hoffman's marl pit, detailed view; $C$, Farmingdale marl pit; $D$, Potash plant of the R. S. Ryan Co. at Reeves station................ 80

X. Stratigraphic comparisons of borings...................... 134

Fiqure 1. Geologic index map of New Jersey ........................ 3

2. Sketch map of part of the Salem district................... 21

3. Sketch map of part of the Woodstown district................ 30

4. Map of the property of the West Jersey Marl \& Transportation Co. and adjoining property near Sewell station................ 46

5. Sketch map of part of the Somerdale district ............... 60

6. Sketch map of part of the Marlton district. ................. 69

$\mathbf{\nabla}$ 


\section{ABSTRACT OF REPORT.}

The greensand marl belt of New Jersey extends across the State from the vicinity of Sandy Hook at the northeast to Delaware River near Salem at the southwest, a distance of about 100 miles. It is crossed at many places by railroads and by streams that flow into Delaware River.

The potash in the greensand marl occurs chiefly in the mineral glauconite, which is essentially a hydrous silicate of ferric iron and potassium. Nearly all the Cretaceous formations contain glauconite, but only three contain sufficient amounts to be considered commercially important, though in some others it is locally abundant. These three are the Navesink (the lowermost), Hornerstown, and Manasquan marls, which are described respectively as 25 to 40,30 , and 25 feet thick. The marl beds, which form part of the Coastal Plain strata, strike about N. $55^{\circ} \mathrm{E}$. and dip about 33 feet to the mile southeast, but there are some variations. The gently inclined and poorly consolidated beds that compose the marl are beveled by erosion and covered to a greater or less extent by later deposits.

Five type areas were explored by borings and made the basis of specific estimates. These were at Salem and Woodstown, in Salem County; Sewell, in Gloucester County; Somerdale, in Camden County; and Elmwood Road, in Burlington County. The data gathered from borings were supplemented by well data, both published and unpublished, and by field data on file in the office of the State department of conservation and development.

It is conservatively estimated that the New Jersey greensands contain $256,953,000$ short tons of potash $\left(\mathrm{K}_{2} \mathrm{O}\right)$ that could be mined by open-pit methods. At the rate of importation for the five years preceding the World War, including 1914, this quantity could supply the needs of the United States for nearly 1,000 years. Should it ever become practicable to use underground methods of mining, the available quantity of potash would be enormously increased.

The lime sand in probable commercial thickness is exposed or has been recognized in wells as far north as Wrightstown.

Four companies have undertaken to produce or utilize the potash from New Jersey greensand. Small quantities of potash have been produced and marketed by some of these companies, but none are now producing. The potash industry of the United States was dealt a 
severe blow by the conditions arising after the armistice was declared. It seems probable, however, that some of the large developments will survive. Whether or not greensand may have a place in the American potash industry will depend on how well the greensand operators may be able to compete not only with German producers but also with American producers of potash from other sources.

Recent experiments indicate that the potash in greensand is promptly available to meet the needs of many and perhaps most farm crops.

Composite samples, so prepared as to represent the principal beds of commercial thickness at each of the localities drilled, were washed and the residues magnetically separated and sized. A variety of determinations upon original or prepared samples were also made in the chemical laboratory of the United States Geological Survey. The results of these separations and determinations are discussed both in their relation to the recovery of potash from greensand and in their bearing on the origin of glauconite. 


\title{
POTASH IN THE GREENSANDS OF NEW JERSEY.
}

\author{
By George Rogers Mansfield.
}

INTRODUCTION.

\section{PURPOSE AND SCOPE OF INVESTIGATION.}

The work on which this report is based was begun in the fall of 1918 as a part of the systematic search for potash conducted by the United States Geological Survey since 1910.

The New Jersey greensand marls have long been known to contain small amounts of potash, lime, and phosphate. For more than 100 years they were dug and marketed as fertilizer, and in the late sixties the annual amount so used aggregated nearly $1,000,000$ tons. ${ }^{1}$ With the introduction of prepared fertilizers the marl industry died away, but small amounts of greensand are still dug and used here and there.

It has been considered impracticable to extract commercially the potash from greensand because of the relatively insoluble character of the mineral in which the potash is locked up. Of late years, however, there has been considerable experimentation in processes of extracting potash from silicate minerals, and the New Jersey greensands, which are silicates, have attracted attention because of their accessibility, abundance, and relative ease of mining. The scarcity of potash resulting from the shutting out of German supplies during the World War gave impetus to these experiments and permitted hope of the establishment of a potash industry in the United States in which the New Jersey greensands might be an important factor.

Much general information about the greensands was available through the published reports of the Geological Survey of New Jersey and of the United States Geological Survey and from other sources. The greensand beds had been mapped and described in considerable detail. There was, however, little specific knowledge regarding the quantity, thickness, and character of the deposit and the accompanying overburden at any particular place. The purpose of the work, therefore, was to procure data sufficient to permit estimates of the tonnage of potash in certain areas that are 
favorably situated for commercial enterprise, and to determine the nature and thickness of the overburden in those areas.

The investigation was begun at the instance of the United States Geological Survey, but the New Jersey Department of Conservation and Development cooperated in it, with the understanding that the cost of the work should be divided as nearly equally as possible between the State and the Federal Survey. The money actually expended in field work amounted to $\$ 2,884$, of which the State paid $\$ 1,550$ and the Survey $\$ 1,334$. The Survey, however, furnished the time of the field geologist and the numerous chemical analyses and assumed the other expenses incidental to the preparation and publication of the report.

\section{ACKNOWLEDGMENTS.}

The writer desires to express his thanks to Dr. Henry B. Kümmel, State geologist, and his staff for much helpful information and for the use of unpublished data, including field notes, manuscript maps, and well records. Several days were spent at his office in the study of this material. Dr. Kümmel accompanied the writer on several trips to different parts of the marl belt, one of which was made possible by the kindness of Prof. Gilbert Van Ingen, of Princeton University, who gave his time and the use of his automobile. Dr. M. W. Twitchell, assistant State geologist, went over some 500 cards in search of analyses that might bear on potash exploration, hunted out numerous well records, and kindly permitted the use of his unpublished manuscript on the water resources of the State.

The numerous analyses embodied in this report were made in the laboratories of the Geological Survey, mostly by R. K. Bailey, though some were made by Chase Palmer and E. T. Erickson. George Steiger, chief chemist, made many helpful suggestions, and W. B. Hicks, of the laboratory staff, visited parts of the field with the writer. E. S. Larsen, jr., examined a number of thin sections and made helpful suggestions. Hoyt S. Gale, geologist in charge of the potash investigations of the Survey, Mr. Hicks, and Miss M. R. Nourse have contributed valuable suggestions and criticism.

The writer is indebted to the following persons for permission to drill on their land: Messrs. Louis A. Fogg, T. R. Miller, and Lucius Hires, of Salem; Mr. Isaac K. Lippincott, of Woodstown; Mr. J. C. Voorhies, of Woodbury, secretary of the West Jersey Marl \& Transportation Co. (owner of property at Sewell); Mr. Thomas McMichael, of Somerdale (Laurel Springs post office); Mr. Alfonso Fusco, of Elmwood Road; Dr. E. W. Taylor, of Germantown, Pa. (owner of property near Vincentown); Dr. J. Clifford Haines, of Vincentown; the Norcross \& Edmunds Co., of Birmingham; Mr. W. G. Taylor, of Pemberton; Mr. Alfred Cox, of Juliustown; and Miss Rebecca 


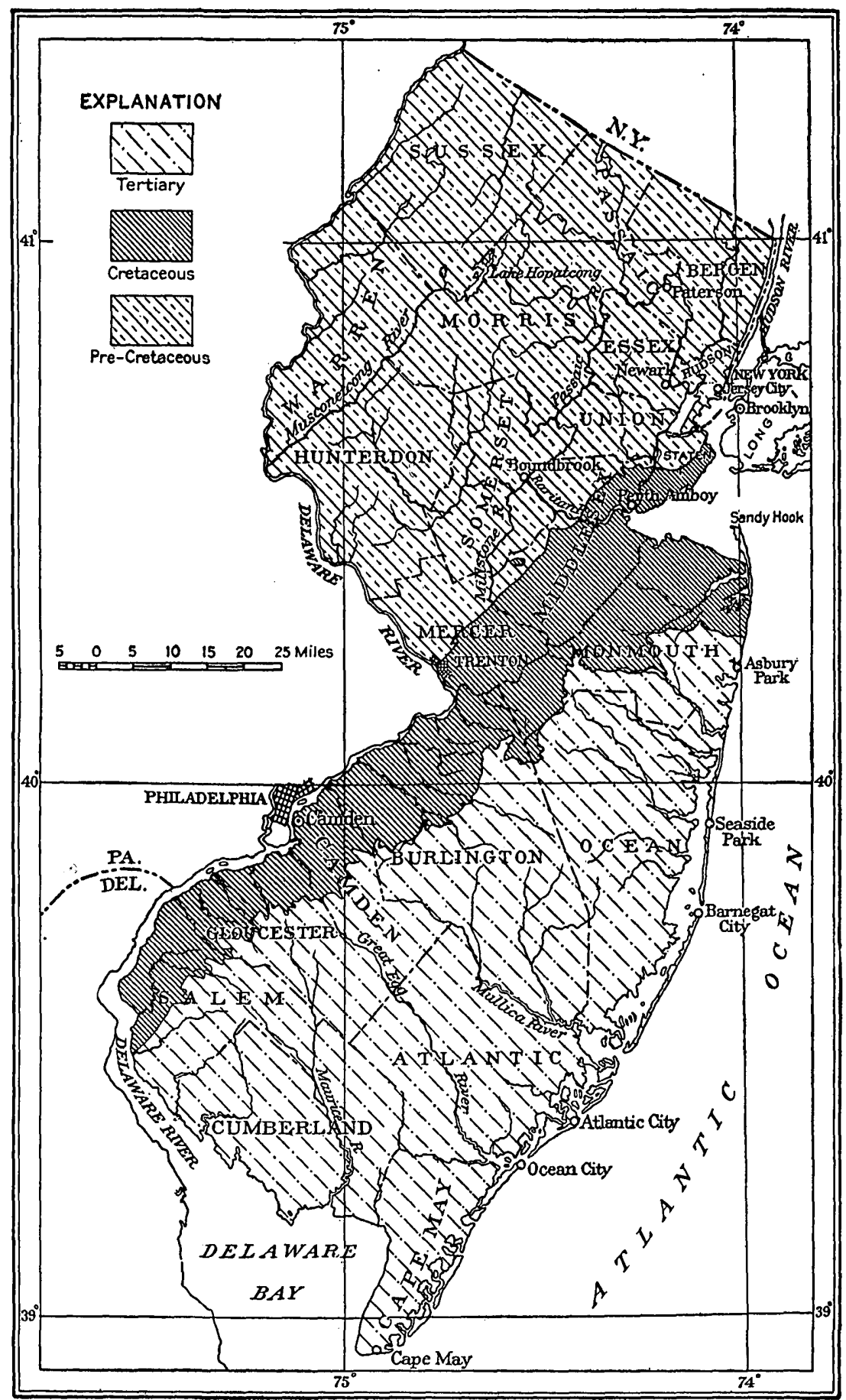

Fiaure 1.-Geologic index map of New Jersey, showing the general distribution of the pre-Cretaceous, Cretaceous, and post-Cretsceous formations. 
Hopkins, of Hornerstown. Unfortunately time was not sufficient for drilling at all these places. Mr. William T. Hoffman, of Birmingham, furnished useful information.

Messrs. Oren Conover and Chalkley Haines, of Woodstown, and William B. Cooper, A. G. Dunphey, and Samuel R. Cooper, of Marlton, furnished local well data. Messrs. C. C. Holladay, of Harmersville, John L. North, of Sewell, and S. J. Taylor, of Mount Holly, contributed well data and helpful field suggestions.

To the officials of the R. S. Ryan Co. the writer is indebted for numerous courtesies, especially to Mr. F. Tschirner, who conducted him through the plant at Reeves station while it was in operation and permitted the collection of specimens and other data on the company's property. Mr. George F. Von Kolnitz kindly furnished data regarding the process and plans of the Atlantic Potash Corporation. Messrs. T. C. Meadows, general manager, and George Hafer, engineer of the Eastern Potash Corporation, furnished valuable information and courteously arranged for an inspection of the corporation's experimental plant at Jones Point, N. Y. Mr. David L. Frank, vice president of the Coplay Cement Manufacturing Co., of Coplay, $\mathrm{Pa}$, was kind enough to explain the company's experience in the use of greensand.

The personal kindnesses extended to the writer by the residents at different places during the progress of the work are too numerous to mention individually but are gratefully appreciated.

\section{LOCATION OF DEPOSITS.}

The greensand-marl belt extends across the State of New Jersey from the vicinity of Sandy Hook, at the northeast, to Delaware River near Salem at the southwest, a distance of nearly 100 miles. It lies along the southeastern border of the broad strip of Cretaceous deposits shown on the index map (fig. 1). The width of the belt ranges from nearly 14 miles in Monmouth County, at the northeast, to 1 mile or less in parts of Gloucester County, toward the southwest. The detailed distribution of the greensand marl is shown in Plates I to III (in pocket), compiled from unpublished maps prepared by G. N. Knapp, formerly of the New Jersey Geological Survey.

\section{TRANSPORTATION FACILITIES.}

The railroads that connect the seashore resorts along the coast of New Jersey with New York, Philadelphia, and other cities (see fig. 1) cross the marl belt at a number of places and could supply suitable transportation for potash and other products that might be derived from the greensand. The marl belt is also crossed by numerous streams which flow into Delaware River, some of which, such as Mantua, Rancocas, and Crosswicks creeks, are large enough to be utilized, at least in part, for transportation. Companies pro- 
posing to establish plants for utilizing greensand would do well to consider the possibilities of water transportation in their estimates of cost.

\section{GENERAL FEATURES OF THE DEPOSITS.}

\section{CHARACTER}

The potash occurs chiefly in the mineral glauconite, which constitutes the green grains of the so-called marl. The term "marl" as used in New Jersey includes a variety of materials. Thus we have greensand or glauconitic marl, clay marl, sand marl, and lime sand or lime-sand marl. Ordinarily greensand is implied when the term is used, but one or more of the other types is frequently included, especially in well records, so that it is difficult or impossible to make any detailed stratigraphic interpretation of many of these records.

The greensand beds are in general unconsolidated deposits consisting of variable proportions of glauconite grains, clay, quartz, and a variety of small fragments of other minerals. A more detailed description of these constituents and their relative proportions is given in the sections on mechanical analyses of greensand, chemical analyses, and nature and origin of glauconite. (See pp. 116-133, 138-142.)

The glauconite imparts a greenish color to beds in which it occurs, and beds consisting largely of dark-green or black glauconite appear nearly black when freshly opened. The claylike constituents, where abundant, impart color to the beds. Thus some are light green, but others are dark green, drab, or chocolate-brown, although in each bed the glauconite grains are generally dark-green or nearly black. Likewise where quartz grains are abundant the beds have a color resembling that of a mixture of pepper and salt. There is much similarity of appearance between masses of the black phase of the greensand and masses of disintegrated material from beds of black or brown oolitic phosphate rock in the Idaho field.

The glauconite grains range in size from less than one one-hundredth to more than one-twentieth of an inch. Some of the larger grains resemble casts of shells of Foraminifera. Many appear to be more or less irregular aggregates of small rounded masses, and others seem to be small nodules irregularly cracked and recemented. The smaller sizes are worn and have evidently been transported to their present positions from neighboring or other sources. (See PI. IV.) Clay with grains of glauconite forms nodules and casts of shells. Nodules containing more or less pyrite are present here and there, and locally tiny grains of pyrite occur. Nodules of phosphate of lime are also present.

Marine shells and other marine fossils representing a considerable fauna have been found in the greensand beds. The shells are scat- 
tered to some extent through the mass of the greensand, but there are two beds in which they are very abundant and which serve as horizon markers. These are respectively the Belemnitella-bearing bed, at the base of the Navesink marl, and the Terebratula-bearing bed, at the top of the Hornerstown marl. These formations are described on pages 10 and 11 .

The bedding of the greensand, so far as observed, seems relatively uniform and free from cross-bedding, though locally streaks of differently colored clay occur in a single set of beds. For example, at Sewell, where greensand is dug, the upper 2 feet of chocolate-colored material at the top of the so-called chocolate marl is streaked with green material of similar texture. At Somerdale a bed of drab material about 18 feet thick shows more or less streaking of gray and green throughout.

\section{STRIKE, DIP, AND THICKNESS.}

According to previous reports the average strike of the greensand beds is about N. $55^{\circ} \mathrm{E}$. The dip is estimated by Knapp at 33 feet to the mile, with some variations, for a distance of 15 miles back from the outcrop; at greater distances it apparently steepens. The gentle inclination of the beds and the erosion they have suffered cause them to wedge out along the northwest margin of the marl belt. The thickness therefore ranges from a few inches along the northwest margin to nearly 50 feet in places along the southeast margin. Variations in thickness along the strike are due to local erosion or to differences in conditions of deposition.

\section{LOCAL NAMES.}

The greensand beds at some localities show sufficient variation in color and constituents to give rise to useful local names. Thus at Sewell three types are recognized-gray or bank marl, green marl, and chocolate marl. These names are applied to beds of commercial thickness, which are traceable through a considerable area. At Somerdale a small deposit consisting chiefly of quartz grains, iron oxide, clay, and a little glauconite is called red marl.

\section{MODE OF OCCURRENCE.}

The marl belt is part of the New Jersey Coastal Plain, which in turn is in the northern part of the great Coastal Plain that extends along the Atlantic and Gulf seaboards. Glauconite deposits occur in greater or less abundance in other parts of this plain and indeed in some of the older geologic formations not now associated with coastal plains, notably in the Cambrian sandstones of parts of the West and Southwest. According to present knowledge, however, the glauconite beds of New Jersey are probably richer in potash than those elsewhere. 


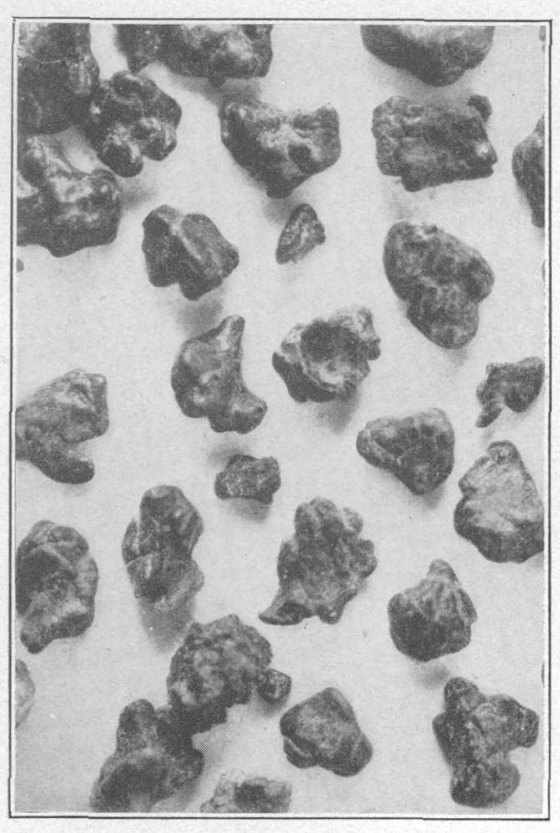

$A$

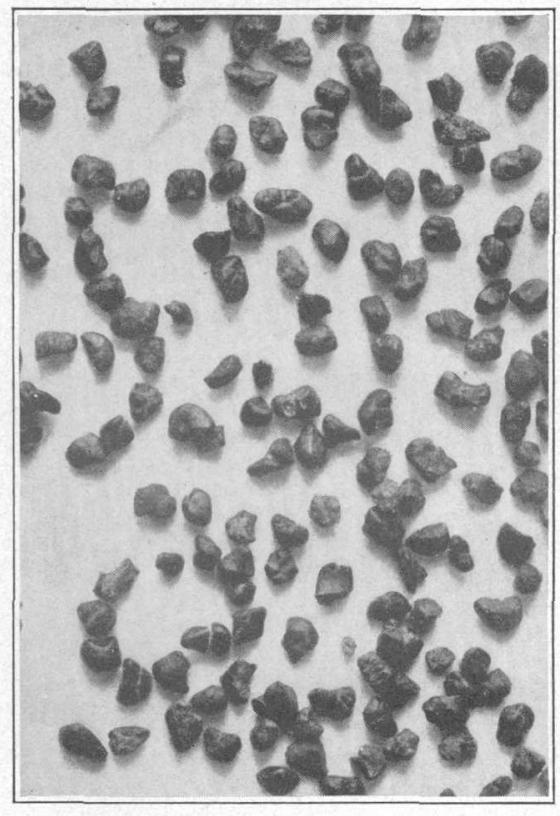

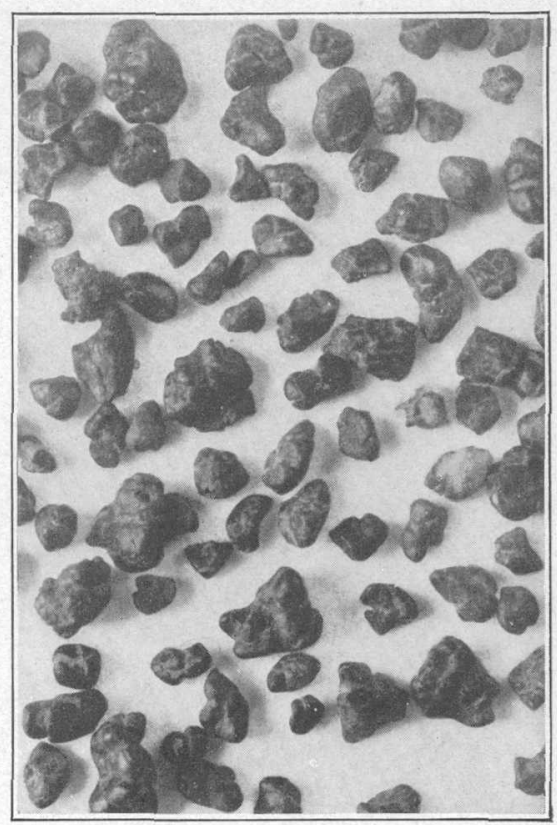

$B$

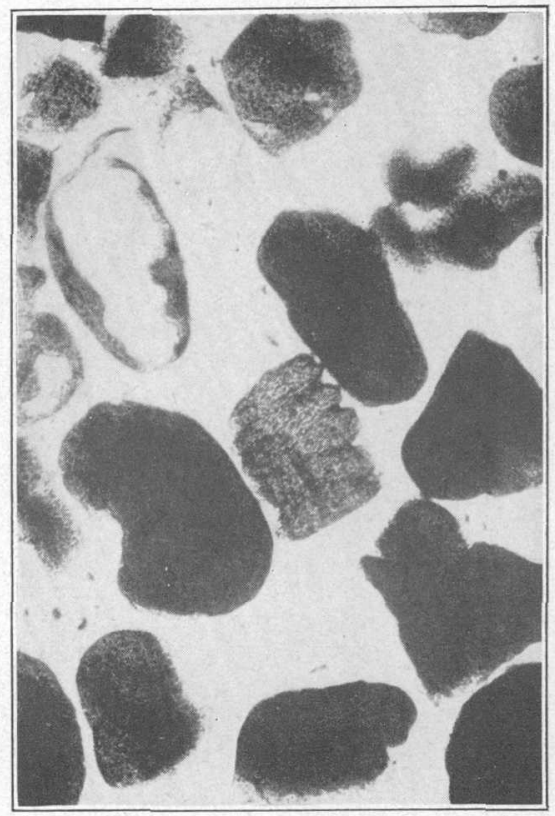

$D$

MICROPHOTOGRAPHS OF GLAUCONITE.

$A$, Grains between $1 / 10$ and $1 / 20$ inch in diameter, the maximum size, $\times 10$, showing characteristic shapes; $B$, grains between $1 / 20$ and $1 / 40$ inch, $\times 10$, shapes similar to those in A but more worn; $C$, grains between $1 / 40$ and $1 / 60$ inch, $\times 10$, shapes similar to those in $A$ and $B$ but considerably more worn; $D$, thin section of glauconite grains between $1 / 40$ and $1 / 60$ inch, $\times 50$, showing the flaky to granular structure of the glauconite and in the center a supposed crystal with rude cleavage. 
The Coastal Plain in New Jersey has long been cited as an example of the belted type, with inner lowland, in-facing slope, out-facing slope, and outer lowland, caused by the erosion of gently dipping strata of somewhat unequal degrees of coherence or hardness and by the development of drainage upon those strata. The marl beds lie near or at the top of the in-facing slope and thus relatively near Delaware River, which occupies much of the inner lowland, and their drainage in general flows toward that lowland, producing the favorable conditions for water transportation previously noted.

\section{GLAUCONITE-BEARING AND ASSOCLATED FORMATIONS.}

Age and general sequence.-The glauconite beds of New Jersey, with one exception, are of Cretaceous age. Glauconite occurs locally, however, in some of the overlying Tertiary and Quaternary beds as a result of the erosion and redeposition of Cretaceous material. At some places, as for example, at Somerdale, about 9 miles southeast of Camden, these reworked glauconite beds overlie beds of Cretaceous greensand and may readily be mistaken for them. Closer inspection of the reworked material reveals pebbles scattered through its mass and usually a more or less well-defined layer of pebbles at its base. The Cretaceous formations are described below and are shown with the overlying Tertiary formations in the accompanying table. ${ }^{2}$

Cretaceous and later formations in Coastal Plain region of New Jersey.

\begin{tabular}{|c|c|c|c|}
\hline System. & Series. & Formation. & $\begin{array}{l}\text { Thick- } \\
\text { ness } \\
\text { (feet). }\end{array}$ \\
\hline \multirow[b]{2}{*}{ Quaternary. } & Recent. & Beach sand and gravel, marsh deposits, and alluvium. & \\
\hline & Pleistocene. & 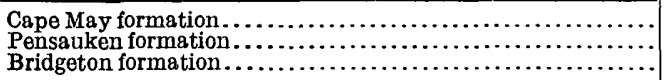 & $\begin{array}{l}0-20 \\
0-20 \\
0-30\end{array}$ \\
\hline \multirow{4}{*}{ Tertiary. } & Pliocene (?). & 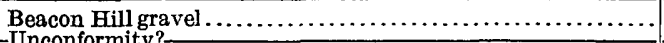 & \\
\hline & Miocene (?). & 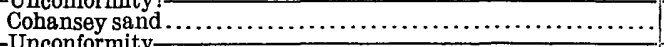 & $100-250$ \\
\hline & Miocene. & 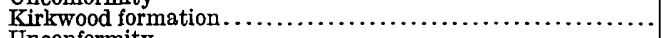 & 100 \\
\hline & Eocene. & -Unconformity & 11 \\
\hline Cretaceous. & $\begin{array}{l}\text { Upper Creta- } \\
\text { ceous. }\end{array}$ & 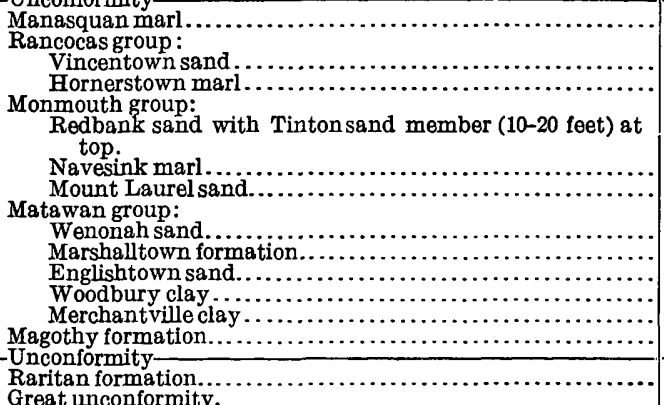 & $\begin{array}{r}25 \\
25-70 \\
30 \\
0-10 \\
25-40 \\
5-60 \\
20-35 \\
30-35 \\
20-100 \\
50 \\
60 \\
25-175 \\
150-250\end{array}$ \\
\hline
\end{tabular}

2 Tableand descriptions compiled chiefly from New Jersey Geol. Survey Bull. 14,1915; U. S. Geol. Survey Geol. Atlas, Philadelphia folio (No. 162), 1909, and Trenton folio (No. 167), 1909. 
Raritan formation.- The beds of the Raritan formation are of continental origin and extremely variable, consisting chiefly of lightcolored sands and clays. Some of the clays are highly refractory. Clays are more abundant in the lower half of the formation and sands in the upper half. Some of the sands are water-bearing. As the surface on which the beds were laid down was irregular the thickness of the formation is variable, ranging from 150 to 250 feet at the outcrop but increasing toward the southeast to more than 500 feet, as shown by well borings. Its dip is somewhat steeper than that of the marl beds, ranging from 40 to 50 feet to the mile toward the southeast. Animal remains are scarce, but plant remains are numerous, and some of the genera and species are closely related to modern forms. The formation rests in places on Triassic rocks, but from the vicinity of Trenton southward it rests on ancient crystalline rocks of Paleozoic or pre-Paleozoic age.

Magothy formation.-The Magothy formation is partly of continental and partly of marine origin and includes beds of sand and clay, some of which are utilized, with glauconite beds toward the top. On the shores of Raritan Bay the formation is 175 feet thick, but its thickness diminishes toward the southwest and along Delaware River is only 25 to 30 feet. Plant remains of a somewhat more recent aspect than those of the Raritan are numerous, and 43 species of marine fossils have been recognized. The Magothy lies unconformably upon the Raritan, but the discordance is not great and probably indicates only a slight land movement. The Raritan and Magothy formations are the chief sources of clay in the great center of the industry about the lower Raritan River and Raritan Bay.

Merchantville clay.-The Merchantville formation is a black glauconitic, micaceous clay about 60 feet thick, which is generally greasy in appearance and of massive structure and weathers to an indurated brown earth. It is conformable with the beds both above and below and contains numerous marine fossils, the most characteristic species of which are rare or absent in adjacent strata. The Merchantville clay represents the lower part of the "Crosswicks clay" of Clark, forms the base of the "Clay-Marl-series" of Cook, and is the lowest of the five formations composing the Matawan group of New Jersey. In Maryland the Matawan deposits are not subdivided and are called the Matawan formation. The Merchantville clay is utilized with the overlying Woodbury clay in the manufacture of brick and freproofing material along the south shore of Raritan Bay in Monmouth County, in southern Middlesex and Mercer counties, and in western Burlington and Camden counties.

Woodbury clay.-The Woodbury clay is a black nonglauconitic jointed clay about 50 feet thick which weathers to a light chocolate color and when dry breaks into innumerable blocks, many of them showing 
curved surfaces of fracture. Some 95 species of marine fossils have been recognized, and these are more closely related to the Magothy species than to those of the underlying Merchantville. The beds are conformable with those above and below. They represent the upper part of the "Crosswicks clay" of Clark and are part of Cook's "Clay-Marl series." The formation is one of the five formations of the Matawan group.

Englishtown sand.-The Englishtown is a conspicuous bed of white or yellow quartz sand, slightly micaceous and sparingly glauconitic. Locally it has been cemented in part by iron oxide into massive stone. South of Woodbury, in Gloucester County, it contains local beds of clay that are utilized for making brick. In Monmouth County and to some extent farther south the Englishtown sand is an important water-bearing bed. It decreases in thickness from 100 feet near Atlantic Highlands to less than 20 feet in the southern part of the State. It represents the lower part of the "Hazlet sands" of Clark and forms part of Cook's "Clay-Marl series." It was formerly called the "Columbus sand" and is one of the formations of the Matawan group. It is not known to contain fossils.

Marshalltown formation.-The Marshalltown formation ranges from a black sandy clay to a clayey greensand marl. Locally it contains many fossils, its characteristic species being in part recurrent forms from the Merchantville and in part forms that occur in a higher formation, though absent or inconspicuous in immediately succeeding beds. The formation is 30 to 35 feet thick. It is a portion of the "laminated sands" that formed the upper part of the "Clay-Marl series" of Cook, although in the southwestern part of the State he referred these beds to the Navesink marl. It was included in Clark's "Hazlet sands" and is one of the formations of the Matawan group. In parts of Burlington and Camden counties beds of clay in the Marshalltown formation are used for the manufacture of brick. The greensand of the formation is locally abundant and has been dug for fertilizer.

Wenonah and Mount Laurel sands.-Above the Marshalltown formation there is a considerable thickness of sand regarding which there has been some difference of opinion. The terms Wenonah and Mount Laurel have both been applied to it in whole or in part. The sand is of rather uniform character, though the lower part (Wenonah) is generally a fine micaceous sand, and the upper part (Mount Laurel) is coarser and contains considerable glauconite. These sands contain considerable water in the southern and central parts of the State, where they are about 80 feet thick, but toward the northeast they decrease both in thickness and in permeability. 
The fossils of the Wenonah are largely recurrent from the Woodbury, and the same forms recur higher in the Redbank. The fossils of the Mount Laurel are identical with those of the Navesink and are closely allied to those of the Marshalltown. A noteworthy form that occurs in the Mount Laurel and extends into the basal bed of the Navesink is the pencil-shaped Belemnitella americana. The combined thickness of the Wenonah and Mount Laurel formations is 40 to 80 feet. The Mount Laurel is very thin at Atlantic Highlands, where it was called "Sand-marl" by Cook, but increases much in thickness toward the southwest. The Wenonah sand is the highest formation of the Matawan group; the Mount Laurel is the basal formation of the overlying Monmouth group.

Navesink marl.-The Navesink marl consists of greensand marl mixed with varying amounts of quartz sand and fine earth containing much calcium carbonate in a powdery state. Where purest the marl has a dark-green to bluish-black color. The upper part of the bed contains progressively less greensand and is more clayey. The fauna is large, comprising 121 species, according to Weller, and is allied with that of the Marshalltown and Merchantville beds; the characteristic forms of the Magothy, Woodbury, and Wenonah are absent. The basal bed of the Navesink at many localities, as at Mullica Hill, is a shell bed several feet thick (see Pl. VI, $B$ ), in which, as in the Mount Laurel sand, the pencil-shaped Belemnitella americana is conspicuous. Another characteristic feature of this bed is the occurrence of smoothed or polished gravel grains, chiefly quartz, about one-eighth of an inch in diameter, for which Knapp suggested the name "rice gravel." The formation has a maximum thickness of about 40 feet, which diminishes southward to 25 feet or less. It corresponds in general to Cook's "Lower marl," although some beds referred by him to the "Lower marl" have proved to be Marshalltown. It rests conformably upon the beds below and grades upward into the Redbank sand or, where that is absent, into the Hornerstown marl. The Navesink is the middle formation of the Monmouth group. In Maryland the Monmouth deposits are not subdivided and are called Monmouth formation. The Navesink marl has been extensively dug for fertilizer throughout much of the marl belt.

Redbank sand, including Tinton sand member.-The Redbank beds consist for the most part of fairly coarse yellow and reddish-brown quartz sand, locally indurated by the infiltration of iron oxide. The lower beds are in many places somewhat clayey, and the fossils of the Redbank have been found mostly in the clayey layers. The fauna is a recurrence of Magothy, Woodbury, and Wenonah forms and differs in important respects from the Navesink fauna below. The Redbank sand has a maximum thickness of 100 feet in the north- 
ern part of the Coastal Plain, where it is a valuable water-bearing formation, but thins out southwestward and disappears in the vicinity of Skyesville, in the northern part of Burlington County. It is the "Red sand" of Cook and earlier writers but does not include certain sands in the southern part of the State that were erroneously correlated by Cook with the "Red sand" of Monmouth County. With the Tinton sand member at the top it is the uppermost formation of the Monmouth group. The Tinton member consists of a bed of green indurated clayey and sandy glauconitic marl 10 to 20 feet thick in Monmouth County. Its fauna is more closely allied to that of the Navesink than to that of the Redbank and is characterized by large numbers of crustacean claws. It is Cook's "indurated green earth," regarded by him as part of the "Red sand."

Hornerstown marl.-The Hornerstown marl is a bed of glauconite with clay and sand, having a total thickness of 30 feet or less. It does not differ much in appearance from the Navesink, although where unweathered it may have a greener tinge. Its fauna, though meager, is different in essential characteristics from the fauna of all the underlying formations. A shell bed 4 to 7 feet thick at the top of the formation is a conspicuous feature at many localities. The brachiopod Terebratula harlani, which occurs in great numbers in the upper part of the shell bed, is perhaps the most distinctive fossil. At the north the formation rests with apparent conformity on the Tinton. Where that is absent it lies on the Redbank, and farther south, owing to the disappearance of the Redbank, it is continuous with the Navesink and not generally distinguished from it. It is conformably overlain by the Vincentown sand except where overlapped by Tertiary formations. It is the "Middle marl" of Cook and the "Sewell marl" of Clark and forms the lower formation of the Rancocas group, the Vincentown sand being the upper formation. In Maryland the Rancocas deposits are not divided and are called the Rancocas formation. The Hornerstown marl has been extensively dug and used as a fertilizer.

Vincentown sand.-The Vincentown sand presents two phases(1) a calcareous or lime sand, more or less indurated and largely a mass of broken bryozoan, echinoid, coral, and other calcareous remains; (2) a glauconitic quartz sand. The two occur in alternating layers, although the lime sand is more common in the basal portion, particularly to the south, and the quartz sand predominates in Monmouth County. The fauna of the siliceous phase contains elements of the Hornerstown fauna in association with forms characteristic of the calcareous phase. The thickness of the formation ranges from 25 to 70 feet, but numerous well borings have shown that it thickens down the dip-that is, toward the southeast-as do most of the other formations. It rests conformably upon the Horners- 
town marl and is overlain conformably by the Manasquan marl or overlapped by Tertiary beds. The Vincentown sand includes the "lime sand" and "yellow sand" of Cook, the former of which was included by him as a part of the Hornerstown ("Middle") marl, and is the upper formation of the Rancocas group. The formation contains much water throughout the length of the New Jersey Coastal Plain. The more calcareous beds have been used locally for building stone and for burning.

Manasquan marl.-The lower 13 to 17 feet of the Manasquan marl is, like the Hornerstown and Navesink marls, composed largely of glauconite together with sand and clay and has a green or greenishgray color. The upper 8 to 12 feet is made up of very fine sand mixed with greenish-white clay. Piles of this material look like heaps of ashes, whence the name "ash marl." Fossils are not abundant or well preserved. The thickness of the formation is about 25 feet. It corresponds to the "green" and "ash" marls of Cook's "Upper marl bed" and is the youngest of the Cretaceous formations exposed in New Jersey. It rests conformably on the Vincentown and at most exposures is succeeded unconformably by Tertiary or Quaternary deposits, although locally it is overlain by a bluish marl of Eocene age (Shark River marl) without apparent unconformity. The Manasquan marl has been dug and extensively used as fertilizer.

Tertiary and Quaternary formations.-Aside from the local deposits of reworked material already mentioned the Shark River marl (Eocene) is the only post-Cretaceous formation that carries significant amounts of glauconite. The Shark River marl crops out only in a few small areas near Long Branch and Farmingdale, in Monmouth County. Its maximum thickness is only 11 feet, and though apparently conformable upon the Manasquan it is believed from well borings to overlap the Cretaceous. It has little commercial importance.

The succeeding formations are sufficiently described for the purposes of this report in the table on page 7 . They constitute much of the overburden to be encountered in exploitation of the marl.

Commercially important formations.-Although most of the Cretaceous formations above the Raritan contain glauconite, only the Navesink, Hornerstown, and Manasquan marls are sufficiently glauconitic to be of commercial importance. These formations, together with the intervening Redbank, Tinton, and Vincentown sands and Shark River marl; are shown in detail on the accompanying maps (Pls. I-III, in pocket). The full development of the intervening sands in Monmouth County explains the great breadth of the marl belt in that county.

Southwest of Sykesville, in the northern part of Burlington County, the disappearance of the Redbank sand causes the Hornerstown and 


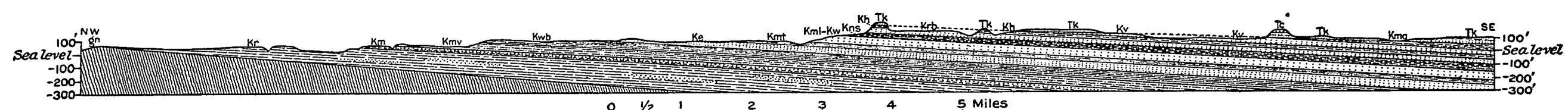

A. GENERALIZED CRoss SECTION OF THE CRETACEOUS AND TERTIARY DEPosits SOUTHEAST OF TRENTON.

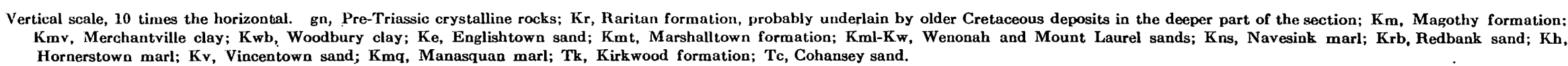

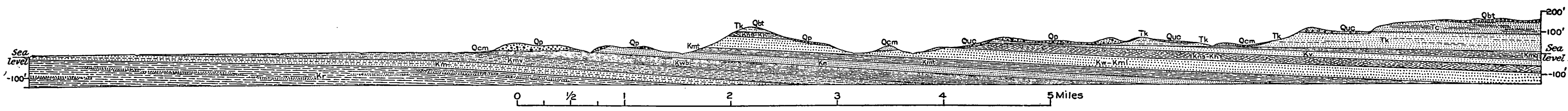

B. SECTION SOUTHEASTWARD FROM CAMDEN, SHOWING SEQUENCE, RELATION, AND STRUCTURE OF CRETACEOUS, TERTIARY, AND QUATERNARY STRATA.

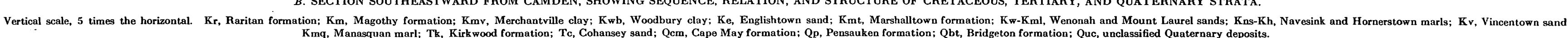


Navesink marls to merge in a single formation in which both faunas may be recognized, but the respective parts of the formation are not clearly differentiated. Similarly the Manasquan marl practically disappears at a point about 4 miles southwest of Medford, in Burlington County. It has been recognized about 8 miles farther southwest in a small exposure near Clementon, in Camden County, and in Swedes Run, Salem County. Thus southwest of the vicinity of Marlton, in Burlington County, the marl belt practically includes only the combined bed of Navesink and Hornerstown and the Vincentown sand, which in that portion of the belt is locally very calcareous.

\section{GEOLOGIC STRUCTURE.}

The geologic structure of the New Jersey Coastal Plain, as shown in Plate V, is that of a series of gently inclined layers of poorly consolidated rock which have been beveled by erosion and many of which have been covered to a greater or less extent by later deposits. These layers of rock may be regarded as in large measure continuous throughout much of the Coastal Plain. Northwest of the area of its outcrop any particular bed is absent, but southeast of that area its depth increases regularly in the direction of the dip.

An idea more or less current in the marl region is that the marl along streams is of better quality than that in places between streams. Consideration of the structure as above outlined should show that a stream bears much the same relation to a marl bed as a carpenter's gouge or saw would to a board that was being shaped or cut. The tool might disclose differences in the grain or quality of the wood in the board but would have no part in producing those differences.

The analogy between the marl and the board is not complete, however, because ground water percolates through the marl at many localities and might be thought capable of removing fine particles, especially beneath stream beds, where underflow may be presumed to be relatively strong. Without a definite knowledge of the amount and distribution of the pore space of the marl in place it is impossible to deny that some removal of fine particles and consequent enrichment of remaining coarser material may be effected by ground water. On the other hand, the marl generally is compact, and the motion of ground water through it must be slow. The more clayey portions of the marl are in many places so tenacious that small dislodged masses of it successfully resist agitation in water for periods of several minutes. The differences noted in the marl are more probably to be ascribed, like the grain of the wood in the board, to original structure. If better marl has been found along streams than elsewhere the reason is probably because it is more abundantly exposed in stream valleys than elsewhere and 
hence has been more commonly dug along the valleys. Further reference to enrichment is made on pages 133-135.

The gentle dip of the marl beds, previously noted, makes the area of their outcrop relatively broad and its outline intricate where crossed by streams. (See Pls. I-III, in pocket.)

\section{NATURE OF THE EXPOSURES.}

In fields and in roads the greensand gives a greenish color to the soil. In such places, however, the marl is likely to be mingled with other material. Locally it has proved to be redeposited marl, sand, and gravel of Quaternary age.

In the days when Cook wrote his general report on the geology of New Jersey, published in 1868, the marl business was flourishing, marl pits were open and shipping was in progress at many points all along the marl belt. With the introduction of prepared fertilizers and the decline of the marl industry most of the pits were abandoned and given over to water, swamps, and vegetation. The sides or banks have slumped and are now overgrown with brush and trees, some of which have trunks 3 to 6 inches in diameter, as in the large pit 2 miles northeast of Richwood, in Gloucester County (locality 44 , Pl. I).

At a few pits, notably at Sewell and Birmingham, digging is in progress or has been recently. These pits give excellent exposures of portions of the beds but do not afford complete sections. Plate VI, $A$, shows some of the recent diggings and gives an idea of the present condition of one of the larger of the old pits. (See also Pl. IX, p. 80.) Exposures in road cuts give only partial sections and are seldom fresh. The same statement is true regarding stream valleys, except that the shell beds are locally well exposed in such places and thus furnish definite information about the position of the top or bottom of a bed. Plate VI, $B$, shows the shell bed at the base of the Navesink as exposed at Mullica Hill, in Gloucester County.

Quaternary beds overlie the greensand deposits in greater or less thickness almost everywhere and are locally difficult to distinguish from them. Tertiary beds are also present as part of the overburden in many places, as at Sewell. Complete sections of fresh material can be had only by boring. For this work doubtless the auger would suffice at many localities, but at others closely packed gravel and pebbles, loose wet greensand, heavy shell beds, or firmly cemented layers offer obstacles that only the drill can overcome.

\section{FIELD WORK.}

Selection of sites for drilling.-Preliminary trips, begun near Imlaystown, in the southwestern part of Monmouth County, and continued southwestward throughout much of the marl belt, soon 


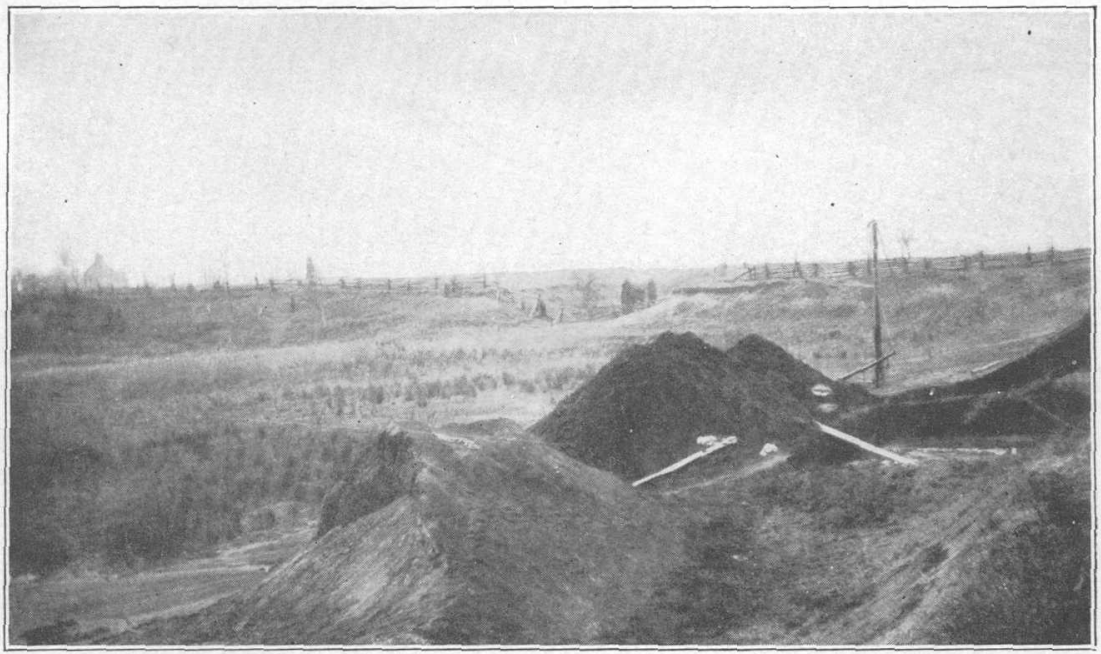

A. GENERAL VIEW OF WILLIAM HOFFMAN'S MARL PIT AT BIRMINGHAM, BURLINGTON COUNTY, N. J.

About three-fourths of a mile northwest of station. Shows recent digging at the north end and, in the distance, the old west bank of the pit.

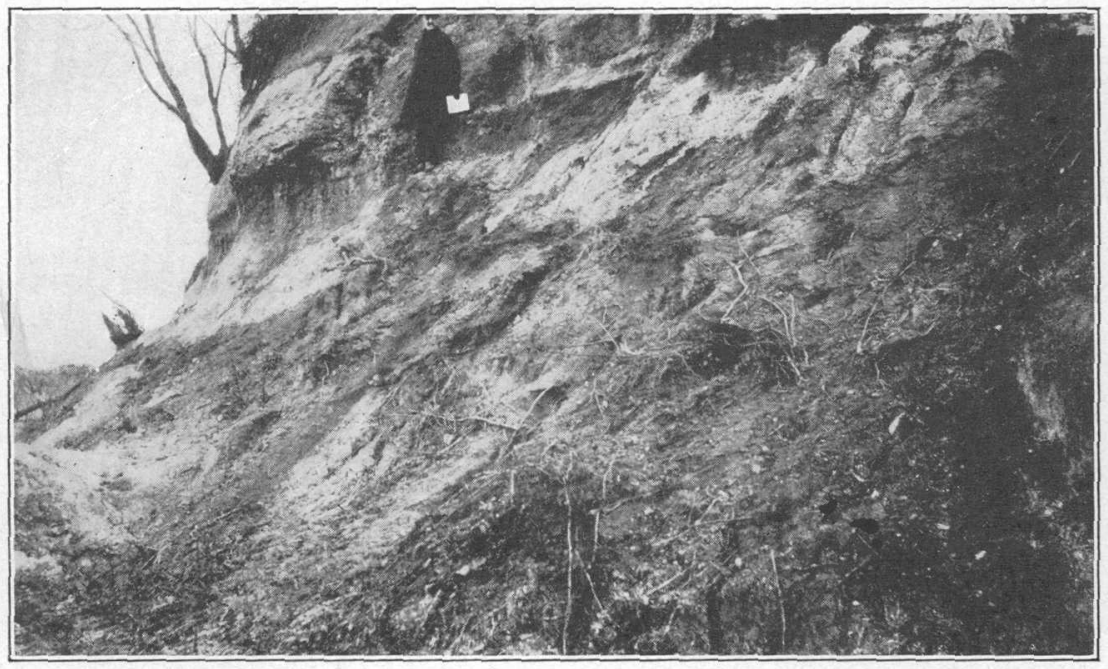

B. SHELL BED AT THE BASE OF THE NAVESINK MARL AT MULLICA HILL, GLOUCESTER COUNTY, N. J., JUST EAST OF STATION. 
demonstrated the need for drilling. Bids were invited, and the contract was let to Samuel J. Taylor, of Mount Holly.

In the selection of sites for drilling five requisites were considered. (1) The sites must be so spaced as to represent a considerable portion of the marl belt; (2) each site must be located in a tract large enough and flat enough for the establishment of a plant and the opening of pits; (3) the probable overburden should not exceed 10 to 15 feet; (4) the site must be along the southeast edge of the outcrop belt in order that the maximum thickness of the marl might be available; (5) the site must be near suitable means of transportation. On the basis of these requisities preliminary sites and alternates were selected by study of the map. These sites were then visited and the surrounding country inspected before final decision was made. The ownership of the land was then determined, and permission for drilling was obtained.

In such manner sites were selected at Salem and Woodstown, in Salem County; Sewell, in Gloucester County; Somerdale, in Camden County; Elmwood Road, in Burlington County; and other places which it was found impracticable to utilize. At each site a square containing $2 \frac{1}{2}$ acres was selected. Holes were sunk at each end of one side and a third hole for a check at the end or middle of the opposite side. At Salem and at Somerdale a fourth hole was sunk outside the square, but at Elmwood Road only two holes were sunk, the contract having expired before the third hole could be started. During the period November 20, 1918, to March 13, 1919, 16 holes were drilled under the contract. These were all in the combined Hornerstown and Navesink marls. In addition, through the courtesy of Mr. A. J. Mullen, superintendent of the Norcross \& Edmunds Co.'s plant at Birmingham and Pemberton, men and tools were furnished for sinking three holes in the Manasquan marl on the property of that company. The distances between drilling sites range from 8 to $12 \frac{1}{2}$ miles.

The holes were sunk generally into or through the marl. They ranged in depth from 9 to 70 feet and averaged 37 feet. Of the 16 holes bored under contract 12 afforded complete sections from the surface through the marl beds. Observations were made on the character and thickness of the materials penetrated, and about 140 samples were collected for analysis. Numerous well records were also gathered.

After the drilling was completed a trip with the State geologist into parts of Monmouth County gave opportunity for brief inspection of additional portions of the marl belt.

Method of drilling.-Considerable variation was found in the character and behavior of the overburden and of the marl in regard to drilling at the different sites and in the different holes at the same 
site. Equipment and methods that worked well at one hole would be unsatisfactory at another. Thus at almost every hole a certain amount of experimentation was necessary to facilitate the work.

For two of the holes at Salem and for the first hole at Woodstown a light outfit, consisting of a 10-horsepower engine, winch, and tripod composed of 20 -foot lengths of $1 \frac{1}{4}$-inch pipe, was employed. Three-inch casing was used, and the drill bit and sand bucket were operated with ropes. Water filled the holes within a few feet of the surface. The marl had comparatively little binder, so that it could be removed only as sludge in the sand bucket. It was therefore necessary to follow the drill closely with the casing. For two of the holes at Salem a Cyclone drill of standard pattern was used. At Woodstown the tripod of the light outfit was replaced by a wooden derrick built into a portable rig, on which the engine and winch were also mounted (see Pl. VII, $A$ ), and this rig with modifications was used throughout the rest of the contract work.

In some of the holes where conditions were favorable the marl was removed directly with an auger. In some of the holes also a cylindrical tube was attached to the drill bar and driven down to obtain a core. This method proved on the whole unsatisfactory. There was more or less interchange from rope to rod tools and back again. The most rapid progress was made by the use of the drill bit and sand bucket attached to light rods and operated by hand by two men. On the Norcross \& Edmunds property an 8-inch posthole auger with overlapping blades, one of which could be raised for removing the load, was used. This was operated by two men.

Method of sampling.-In sampling, as in drilling, the varying conditions at succeeding holes required more or less experimentation at each hole, and improvements in method came as experience with the material to be sampled grew. The aim was to procure fair average samples of all material from the top of the marl to the bottom and to have the samples represent uniform intervals, so far as was practicable. Uniformity of interval was prevented to a considerable degree by the conditions of the work. For example, where a 5 -foot sample was intended a change of material might come within 1 foot and thus necessitate starting a new sample. Again, a change in the type of tool, as from auger to drill, or the close of work for the day before the desired depth had been reached would make advisable the beginning of a new sample.

At holes 6 and 7 at Woodstown, where a given bed seemed uniform, single augerfuls or bailings, taken at uniform intervals or after a noted change in the character of the marl, were considered representative samples. This method saved time but was discontinued in favor of the continuous-sample method. 


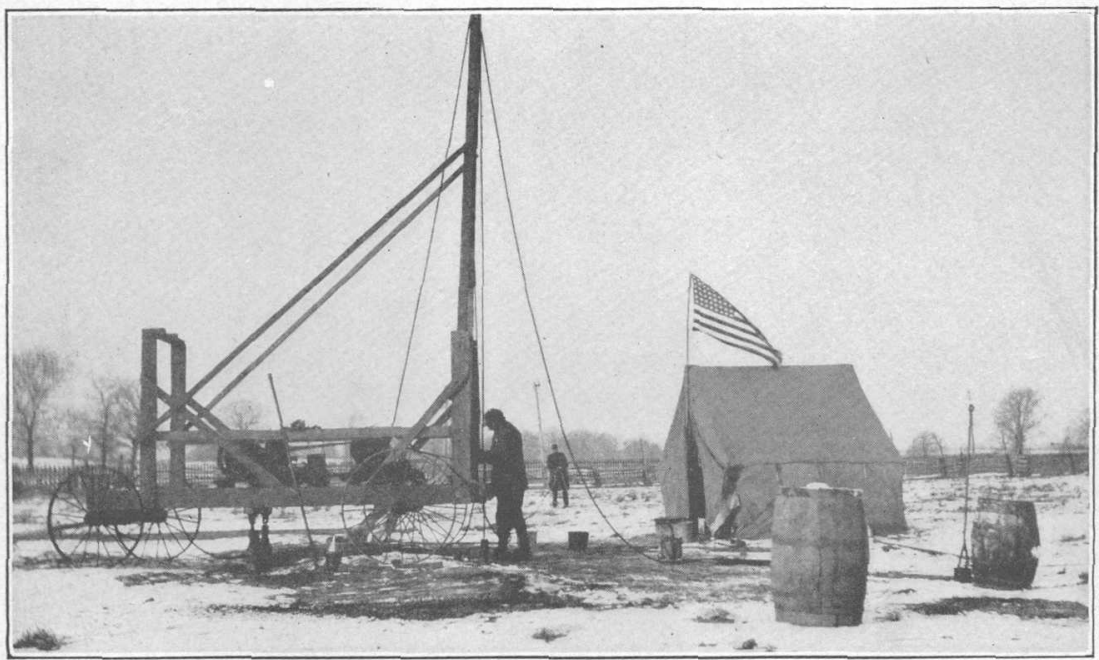

A. DRILLING OUTFIT AND OPERATIONS AT WOODSTOWN, SALEM COUNTY, N. J

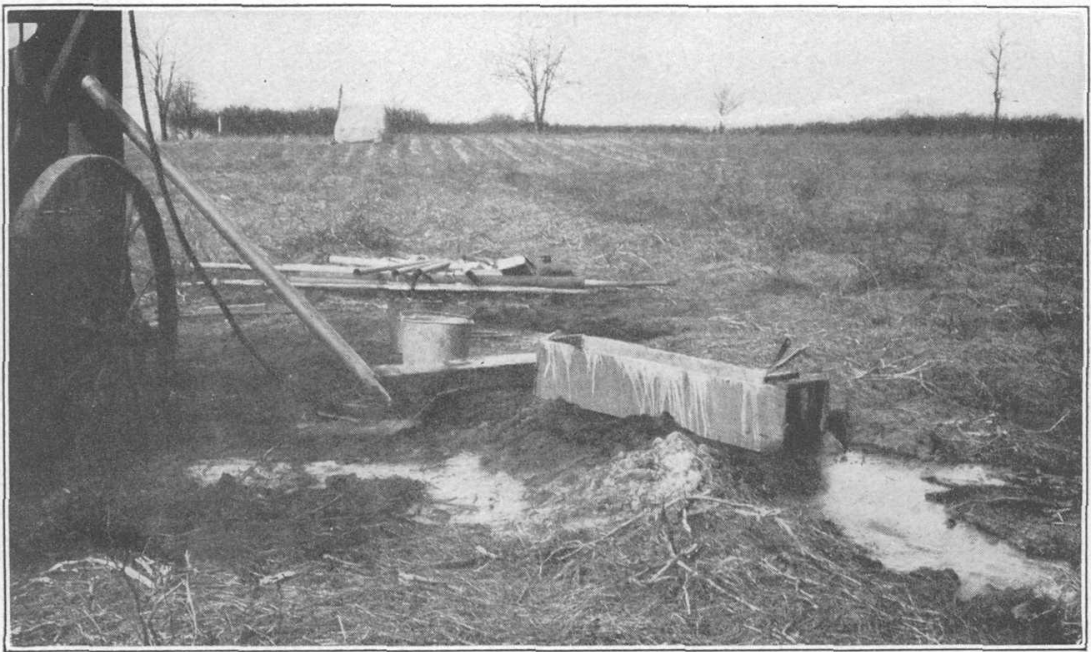

B. SAMPLING TROUGH IN USE AT ELMWOOD ROAD, BURLINGTON COUNTY, N. J. 
So much water was present in most of the holes that the auger was generally ineffective at depths greater than 10 to 25 feet. The cylindrical bit with vertical slit for cleaning was effective in a few places, but where the material was incoherent it could not be brought to the surface. The more tenacious beds were penetrated only with difficulty by the cylinder, and the removal of material from it was very slow. The most expeditious method was drilling and sludging with the sand bucket, care being taken to case off beds that would be likely to modify the sample. Several samples taken by the auger or cylinder were taken in duplicate by the sludge method as a check.

Some experimentation was necessary in handling the material collected for samples. At hole 1, at Salem, the sludge was strained on cheesecloth spread over a perforated bucket or on screens on the ground. There was some loss of the claylike fines, but the lower layers of the sludge served as a filter for overlying layers, so that the loss of fines was thereby reduced. The remaining moist material, with a texture of somewhat clayey sand, was kneaded on oilcloth or canvas and divided six to eight times to duplicate samples weighing about $1 \frac{1}{2}$ pounds.

At hole 3, at Salem, the sludge was collected in barrels and allowed to settle over night, the water being then siphoned off. The remaining material was too wet to divide on canvas. It was therefc:e thoroughly mixed in the barrels and divided by discarding alternate bucketfuls until duplicates weighing about $1 \frac{1}{2}$ pounds were obtained. This method also involved some loss of fines because of the slow settling of the claylike portion and the difficulty of siphoning without stirring the light fines.

At Woodstown two especially constructed boxes, each fitted with a set of three screens, were employed. The solid material from the collecting barrel was spread on cheesecloth on the screens in the hope that it would filter the clayey water of the sample, which was then poured into the boxes. The operation was not successful. Either no water would pass through, or if it did the colloidal matter passed through with it. The collecting and filtering operations, both at Salem and at Woodstown, were seriously hampered by freezing. Filtering was abandoned, and the plan of dividing the solid and liquid portions separately and proportionally was tried, the end products of each division being combined for the final sample, which was then dried in pans over oil stoves, care being taken to avoid overheating and oxidation of the glauconite. It was feasible to collect some of the samples at Woodstown by means of the auger and the core tool. These samples were mixed and divided on canvas and dried on oil stoves.

At Sewell it was also possible to collect some of the samples without sludging, but that method proved necessary for many of them. 
The labor of mixing and dividing large quantities of marl was obviated by using a trough with an end gate for collecting the sludge, as shown in Plate VII, $B$. The sludge in the trough was mixed thoroughly, and a sufficient quantity ladled out to provide duplicate samples, one of which was dried as above described and the other preserved in a 4-ounce wide-mouthed bottle. If more than one troughful was required for a given sample, proportionate amounts were preserved from each troughful and were mixed and divided for the final sample. This method was used at the other localities whenever sludging was necessary, care being taken to keep the sludge as thick as possible and to operate the sand bucket so as to take only material from the bottom of the.hole.

Disadvantages of wet method.-The main disadvantage of the wet method of collecting marl samples is that by loosening the marl some of the finer constituents are mingled with water, and the relative proportions of coarse and fine materials are thereby slightly altered. The coarse constituents of the marl are relatively heavy and settle rapidly to the bottom of the trough, so that it is frequently difficult to get a uniform mixture. There is danger, too, of intermixture of material from farther up the hole, but this may be obviated to a considerable degree by suitable casing.

As shown on pages 125-126, the finer constituents of the marl contain potash in amounts varying from place to place and in different beds at the same place. Where the potash content of the fines of a given sample is less than that of the sample as a whole a loss of fines in collection would mean some enrichment of the sample, or an undue amount of fines collected would mean a corresponding impoverishment of the sample.

Three pairs of samples, one of each pair taken by the auger or core tool and the other by the wet method, at hole 8, at Sewell, show that the wet samples ran lower in total potash than the others by amounts ranging from 0.07 to 0.35 per cent, the average difference, weighted according to the thicknesses represented by the samples, being 0.285 per cent. As similar methods were followed at succeeding holes it seems probable that these figures show the order of discrepancy between the wet and auger or core-tool methods.

The lithologic character and potash content of the samples from Salem and Woodstown are comparable to similar features of samples from other holes, so that there appears to have been no undue enrichment or impoverishment of the samples from those localities on account of fines.

The potash was determined throughout this investigation by the method outlined by Hicks and Bailey. ${ }^{3}$

${ }^{3}$ Hicks, W. B., and Bailey, R. K., Methods of analysis of greensand: U. S. Geol. Survey Bull. 660, pp. 51-58, 1918. 
Determination of weight.-The density and moisture content as well as the potash content were determined for several samples of greensand, as shown in the accompanying table.

Potash, moisture, and density determinations for selected samples of New Jersey greensand.

[R. K. Bailey, analyst.]

\begin{tabular}{|c|c|c|c|c|}
\hline $\begin{array}{c}\text { Field } \\
\text { No. }\end{array}$ & Locality. & $\mathrm{K}_{2} \mathrm{O}$ & $\begin{array}{c}\mathrm{H}_{2} \mathrm{O} \\
\text { at about } \\
100^{\circ} \mathrm{C} .\end{array}$ & Density. \\
\hline $\begin{array}{r}M-7 \\
M-9 \\
M-10 \\
M-63 \\
K \\
\mathbf{R}\end{array}$ & 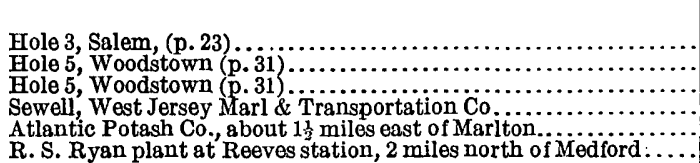 & $\begin{array}{r}\text { Per cent. } \\
6.14 \\
6.48 \\
7.56 \\
7.80 \\
7.63 \\
6.25\end{array}$ & \begin{tabular}{r|} 
Per cent. \\
a 18.48 \\
23.97 \\
24.45 \\
20.50 \\
14.20 \\
17.38
\end{tabular} & \begin{tabular}{r}
$\ldots \ldots \ldots .$. \\
\hdashline 2.958 \\
2,925 \\
3.063
\end{tabular} \\
\hline
\end{tabular}

$a$ Sample damaged before reaching laboratory and contents transferred to bottle; hence $\mathrm{H}_{2} \mathrm{O}$ content may be lower than that of actual sample.

Samples M-7, M-9, and M-10 were collected with the idea of finding how much water the greensand would retain when saturated. They were collected in an excess of water and forwarded to the laboratory in sealed cans. Before analysis they were placed in containers which would prevent evaporation but permit the excess water to drain away. The analyses show that marl taken directly from the pit and loaded without drying in wagons or freight cars, as was done by one company, may contain from 18.5 to nearly 25 per cent of water.

Sample M-63 was collected from a fresh stock pile gathered for shipment at a pit about three-quarters of a mile S. $70^{\circ}$ E. from Sewell station and had been taken from the pit only a few moments before collection. It is a mixture of gray and dark-green marl.

Sample $\mathrm{K}$ was taken from a depth of 20 to 32 inches in the top of a. stock pile that was probably less than a year old. It consisted of a mixture of green and brown marl judged in the field to be of excellent quality.

Sample $R$ came from a freshy opened bed about 10 feet below the surface. It was black marl of apparently good quality.

Four determinations of the weight per cubic foot of greensand as taken from the ground were made in the field by weighing the material used to fill evenly, a measured box of convenient size. A sample of the same material in each lot was preserved for the determination of moisture. The average weight of the material as taken from the ground according to these measurements was about 93 pounds to the cubic foot, or about 2,500 pounds to the cubic yard. The average weight of the dried material calculated from the moisture percentages in the above table was about 79.5 pounds to the cubic foot. A fifth determination of dried residues from several samples obtained at hole 6, Woodstown, gave 81.8 pounds to the cubic foot, but some of these residues had been exposed to the air for several days after 
drying. The average weight of the five dried samples was about 80 pounds to the cubic foot, or 2,160 pounds to the cubic yard.

The figures given above are probably fairly accurate for the weight of the better material as ordinarily handled. Estimates of tonnage, however, are concerned with marl in the ground, which is presumably much more compact than marl removed to stock piles. According to the density determinations given in the table the weight of dry greensand, if massive and compact, would range from 182.7 to 191.4 pounds to the cubic foot and would average about 186 pounds to the cubic foot, or more than 5,000 pounds to the cubic yard. The marl in the ground, being unconsolidated, is probably much less compact than the degree required by this figure. Its actual weight doubtless lies between the two extremes given and for the purposes of estimate may be assumed to be their mean, 133 pounds to the cubic foot or about 3,580 pounds to the cubic yard. The voids, or open spaces due to lack of consolidation, would represent on this assumption 28 per cent of the mass of the marl.

Collection of well data.-During the progress of field work several well drillers were interviewed and farms on which wells had been sunk were visited. The well records at the office of the State geologist at Trenton were searched for data bearing on the districts explored. Published accounts were also reviewed with the hope of extending the inferences based on the drilling.

Other field data.-The field notes of the State geologist and his staff were kindly placed at the disposal of the writer and have been utilized to supplement the information gained by drilling.

\section{GEOLOGIC MAP.}

The geologic map as prepared by Knapp on the scale of 1 inch to the mile $(1: 63,360)$ has been adjusted to the somewhat larger base of the U. S. Geological Survey $(1: 62,500)$.' (See Pls. I-III.) The map does not show Quaternary deposits, and as these are widely distributed throughout the area, it shows the actual surface conditions at comparatively few places. It is valuable, however, in showing the general breadth and outline of the areas in which the marl beds may be presumed to be within reach of the surface and may serve as a useful basis for tonnage estimates for any selected area. In its preparation Knapp visited all available exposures and made frequent tests with the auger. The map may be regarded as generally accurate. One or two slight modifications in it have been made as a result of the writer's observations. At a few other places surface examination suggested further modifications; but without opportunity for the detailed work necessary for revision it was thought best to leave the map unchanged. It is therefore presented essentially as drawn by Knapp but without delineation of the formations preceding the Navesink or succeeding the Shark River. 
All localities discussed are referred so far as practicable to the maps (Pls. I-III), consecutive numbers being employed in order of reference. The locations of many of the wells are not accurately given in the available descriptions. The positions of such wells are indicated on the maps with a query (?).

\section{RESULTS OF FIELD WORK.}

SALEM DISTRICT.

\section{SELECTION AND LOCATION OF SITES.}

Published accounts give little information about greensand marl near Salem, but the geologic map of the State shows both the combined Hornerstown and Navesink marls and the Vincentown sand occupying broad areas near Salem and passing southwestward to Delaware River. Salem has railroad facilities and, through Salem Creek and its tributary Fenwick Creek, excellent means of water transportation. It was therefore decided to make Salem the starting point in the investigation.

The selected drilling sites lay on opposite sides of Walnut Street, about three-quarters of a mile S. $23^{\circ} \mathrm{W}$. from the courthouse, on the farms of Louis Fogg and T. R. Miller. A supplementary hole was started in a field belonging to Lucius Hires, about a quarter of a mile north of the other sites.

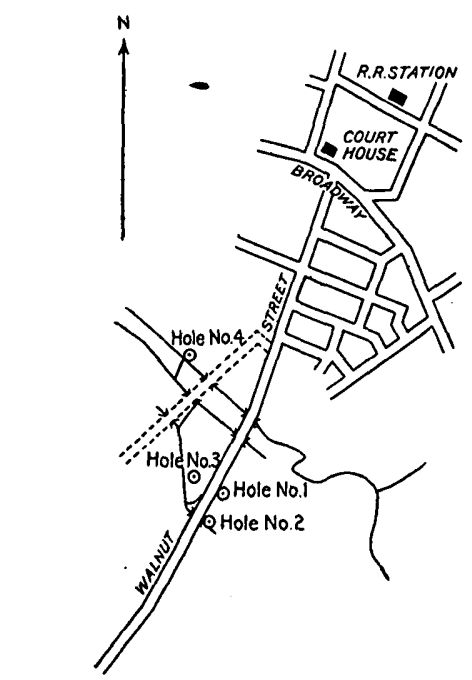

HOLES 1 TO 4.

The overburden at hole 1 proved so thick, 25 feet, that commercial development

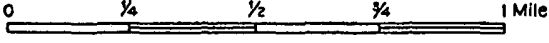

FIGURE 2.-Sketch map of part of the Salem district, showing the location of holes 1-4.

seemed unlikely. It was therefore determined merely to check the thickness and character of the overburden at the other holes in that vicinity and to confirm the character of the marl at one other locality. Thus at hole 2 only the overburden was penetrated; at hole 3 , the overburden and 16 feet of marl, enough to show the presence of marl in commercial quantity and quality. At hole 4 the drill stuck in gravel at a depth of about 9 feet. Work was discontinued because of the thickness of the overburden in holes 1 to 3 and the reported thickness of overburden in wells in the vicinity. The positions of the four holes are shown in figure 2 ; their records follow. 


\section{Records of holes in Salem district.}

Locality 1, hole 1 .

[Farm of Louis Fogg, Walnut Street, Salem, about three-quarters of a mile S. $23^{\circ}$ W. of courthouse. Elevation of surface, about 2 feet. S. J. Taylor, driller. Analysts: Chase Palmer(M-1 to M-4), R. K. Bailey $(\mathrm{M}-\mathbf{5})$.

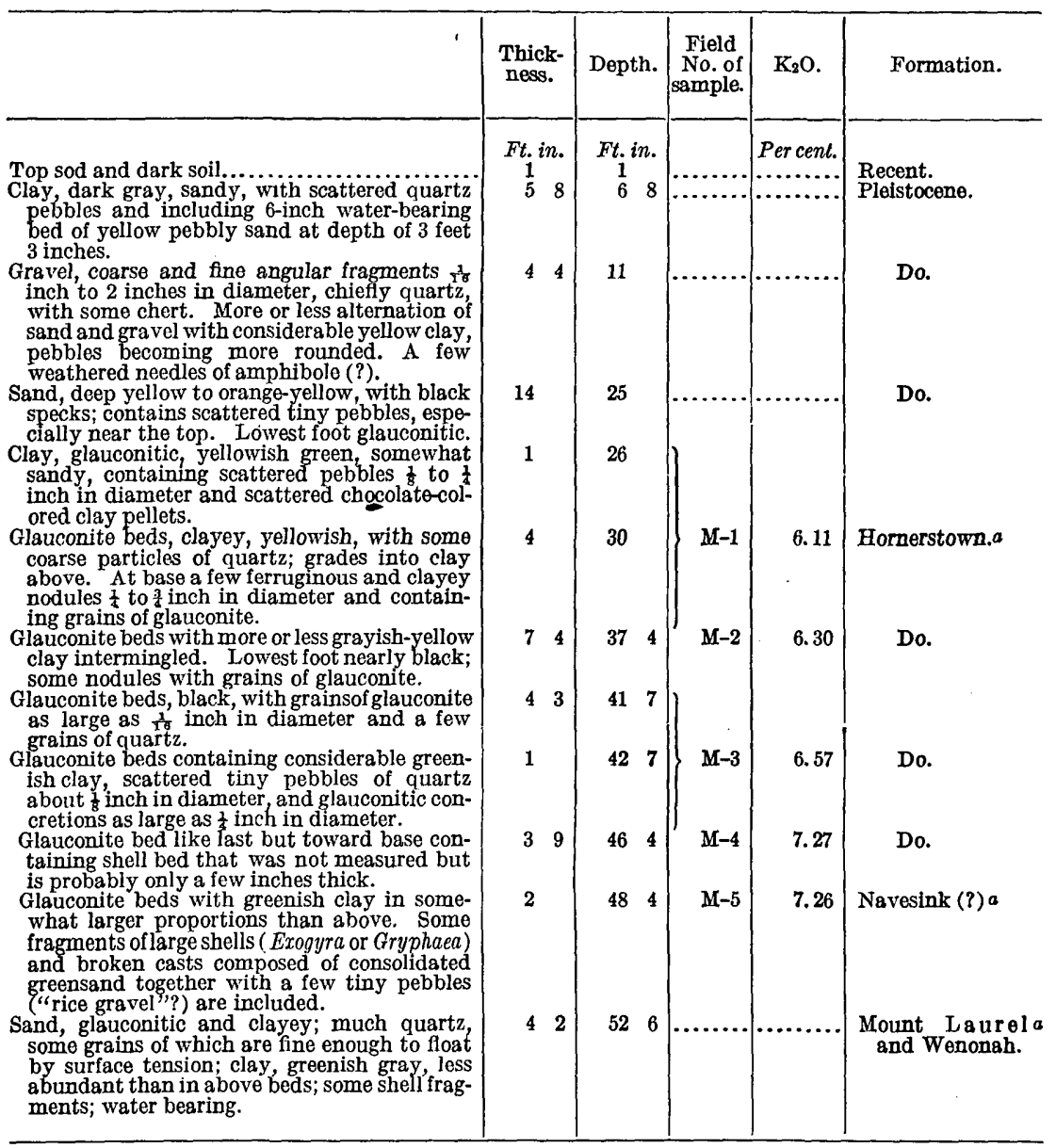

a For the use of these names in this and subsequent records see stratigraphic notes, pp. 135-137.

Locality 2, hole 2 .

[Same general locality as hole 1,310 feet S. $42^{\circ} 3^{\prime}$ W. from it. Surface elevation, about 2 feet. C. C. Holladay, driller.]

\begin{tabular}{|c|c|c|c|}
\hline & $\begin{array}{l}\text { Thick- } \\
\text { ness. }\end{array}$ & Depth. & Formation. \\
\hline 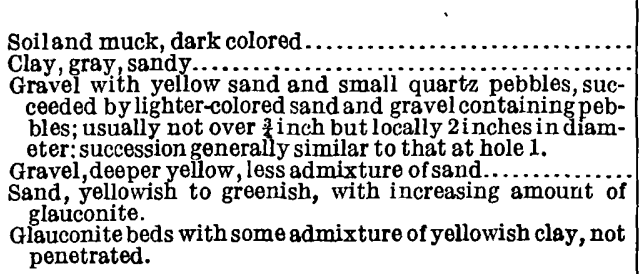 & $\begin{array}{cc}F t . i n . \\
1 & \\
6 & 3 \\
8 & 9 \\
& \\
& \\
8 & 8 \\
& 9\end{array}$ & $\begin{array}{cc}F t . i n . \\
\frac{1}{7} & 3 \\
16 & \end{array}$ & $\begin{array}{l}\text { Recent. } \\
\text { Pleistocene. } \\
\text { Do. } \\
\text { Do. } \\
\text { Vincentown (?). }\end{array}$ \\
\hline
\end{tabular}


Locality 3 , hole 3 .

[Meadow belonging to T. R. Miller, on Walnut Street, about three-quarters of a mile south of courthouse at Salem and 330 feet N. $38^{\circ}$ W. from hole 1 . Surface elevation, about 2 feet. C. C. Holladay, driller. Analyst, R. K. Bailey.]

Top soil and black muck

Clay, bluish gray, very smooth and soft, not gritty like that below soil in holes 1 and 2 .

Clay, brown, peaty, with pieces of twigs and bark.

Gravel, grayish, containing small quartz pebbles and. a pebble of greenstone 2 inches in diameter; becomes yellowish and finer textured with grains of glauconite in the lower part.

Glauconite beds, containing some yellowish clay.

Glauconite bed, at first coarse, then finer, with considerable clay.

Glauconite beds with considerable green clay and scattered grains of quartz as large as $\frac{1}{8}$ inch in diameter;lumps of green clay containing glauconite grains indicate more clayey layer at base.

Glauconite bed like those above; not penetrated

\begin{tabular}{|c|c|c|c|c|}
\hline $\begin{array}{l}\text { Thick- } \\
\text { ness. }\end{array}$ & Depth. & $\begin{array}{c}\text { Field } \\
\text { No. of } \\
\text { sample. }\end{array}$ & $\mathrm{K}_{2} \mathrm{O}$. & Formation. \\
\hline $\begin{array}{c}\text { Ft. in. } \\
2 \\
7\end{array}$ & $\begin{array}{c}F t \text {. in. } \\
2 \\
9\end{array}$ & & \begin{tabular}{l} 
Pcr cent. \\
\hdashline$\ldots$ \\
\hdashline
\end{tabular} & $\begin{array}{l}\text { Recent (?). } \\
\text { Do. }\end{array}$ \\
\hline 7 & 16 & & & Do. \\
\hline 5 & 21 & & $\ldots$ & Pleistocene. \\
\hline 5 & 26 & & . & \\
\hline 5 & 31 & $M-7$ & 6.14 & Hornerstown. \\
\hline 56 & 366 & $\mathrm{M}-8$ & 7.72 & Do. \\
\hline 6 & 37 & & & Do. \\
\hline
\end{tabular}

Locality 4, hole 4 .

[Meadow belonging to Lucius Hires, about 1,350 feet N. $10^{\circ} \mathrm{W}$. from hole 1. Elevation of surface, about 2 feet. S. J. Taylor, driller.]

\begin{tabular}{|c|c|c|c|}
\hline & $\begin{array}{c}\text { Thick- } \\
\text { ness. }\end{array}$ & Depth. & Formation. \\
\hline 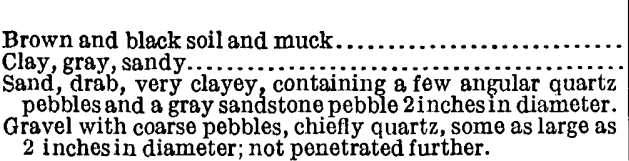 & $\begin{array}{rr}\text { Ft. } & \text { in } \\
1 & 6 \\
4 & 6 \\
& 6 \\
2 & 1\end{array}$ & $\begin{array}{rr}\text { Ft.in. } \\
1 & 6 \\
6 & \\
6 & 6 \\
8 & 7\end{array}$ & $\begin{array}{l}\text { Recent. } \\
\text { Pleistocene. } \\
\text { Do. } \\
\text { Do. }\end{array}$ \\
\hline
\end{tabular}

The data of holes 1 to 3 are summarized in the following table:

Thickness and quality of greensand beds at holes 1 to $\mathrm{s}$, Salem.

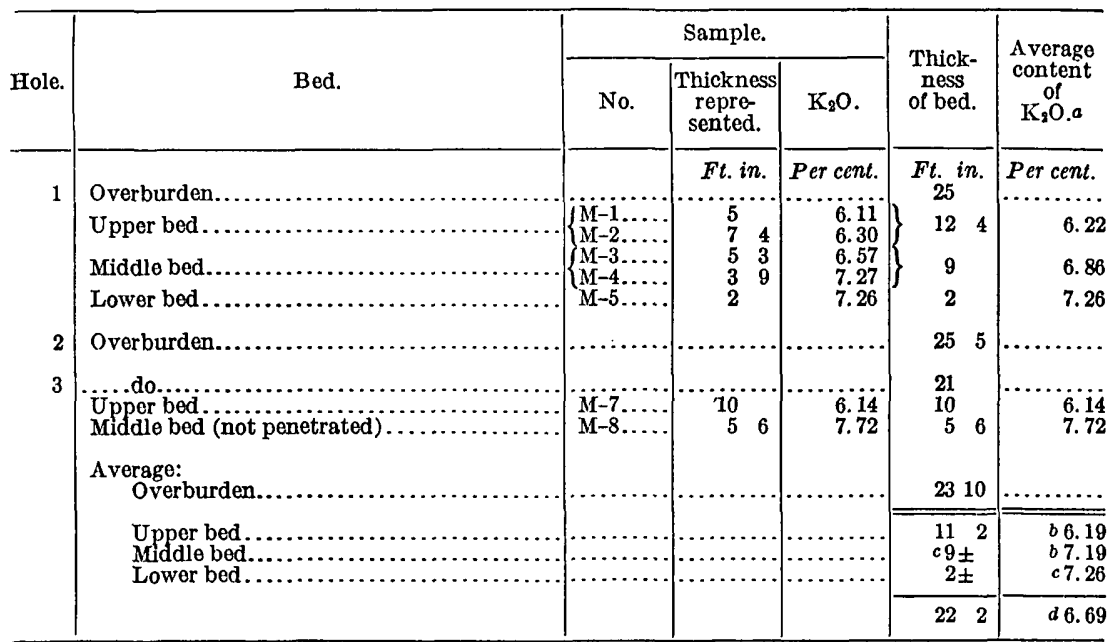

a Average for bed weighted according to thickness represented by the respective samples.

$\checkmark$ Average for bed in 2.5-acre tract weighted according to thickness at respective holes.

$c$ Figures for hole 1 only.

d Average for entire thickness of marl in 2.5-acre tract, assuming that thicknesses for middle and lower beds at hole 1 apply to entire area. 


\section{WELI DATA.}

According to Twitchell ${ }^{4}$ six wells have been drilled at Salem for J. Q. Davis, east of the railroad station, on the margin of the meadow adjoining Fenwick Creek, at an elevation of 3 to 5 feet. Three of these wells are 130 feet deep and three 100 feet. The water rises within 1 or 2 feet of the surface. As is shown by the record below, the wells start in the Vincentown sand, which, with a foot of overlying marsh mud, constitutes an overburden of 20 feet. The combined Hornerstown and Navesink marls are 35 feet thick, and the water is taken from the underlying Mount Laurel and Wenonah sands.

Record of well of J. Q. Davis, at locality 5, Salem.

[Elevation, 3 feet; depth, 130 feet.]

\begin{tabular}{|c|c|c|c|}
\hline & $\begin{array}{l}\text { Thick- } \\
\text { ness. }\end{array}$ & Depth. & Formation. \\
\hline 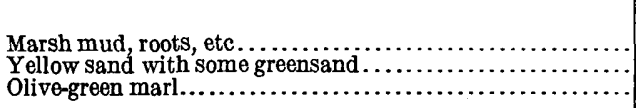 & Feet. $\begin{array}{r}1 \\
19 \\
10\end{array}$ & $\begin{array}{r}\text { Feet. } \\
1 \\
20 \\
30\end{array}$ & $\begin{array}{l}\text { Vincentown. } \\
\text { Hornerstown and Nav- }\end{array}$ \\
\hline 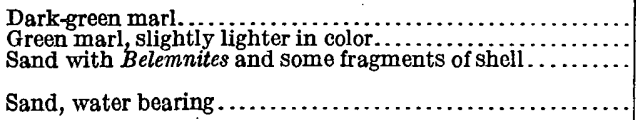 & $\begin{array}{r}10 \\
15 \\
5 \\
70\end{array}$ & $\begin{array}{r}40 \\
55 \\
60 \\
130\end{array}$ & $\begin{array}{l}\text { Do. } \\
\text { Do. } \\
\text { Mount Laurel and } \\
\text { Wenonah. } \\
\text { Do. }\end{array}$ \\
\hline
\end{tabular}

If Twitchell's interpretation of the record at locality 5 is correct the boundary between the Vincentown and Hornerstown should be drawn far enough west to include at least this locality.

A well at Oakdale farm (locality 6), about a quarter of a mile southeast and down the dip of the beds from locality 5, shows 40 feet of marl beneath an overburden of 30 feet of clay, gravel, and sand.

Record of well of Stewart Craven at locality 6 , Salem.

[About 0.4 mile S. $52^{\circ}$ E. from railroad station, oa south side of street. Elevation, about 10 feet. C. C. Holladay, driller and informant.]

\begin{tabular}{|c|c|c|c|}
\hline . & $\begin{array}{l}\text { Thick- } \\
\text { ness. }\end{array}$ & Depth. & Formation. \\
\hline Clay, gravel, sand.... & $\begin{array}{l}\text { Feet. } \\
30\end{array}$ & $\begin{array}{l}\text { Feet. } \\
\quad{ }_{0}\end{array}$ & Pleistocene and Vin- \\
\hline Blue and black marl.... & 40 & 70 & Hornerstown and \\
\hline $\begin{array}{l}\text { Sand with somemarl mixed in it (marl may have come from } \\
\text { above). } \\
\text { Sand with good water } . \ldots \ldots \ldots \ldots \ldots \ldots \ldots \ldots \ldots \ldots \ldots\end{array}$ & $\begin{array}{l}10 \\
23\end{array}$ & $\begin{array}{r}80 \\
103\end{array}$ & $\begin{array}{l}\text { Mount Laurel and We- } \\
\text { nonah. } \\
\text { Do. }\end{array}$ \\
\hline
\end{tabular}

It seems likely that much of the overburden here is Pleistocene rather than Vincentown. The same statement is probably true regarding localities 1 to 4 , as shown by the detailed records. At locality 5 also Pleistocene beds may form a larger share of the overburden than is thought by Twitchell. 
The northwestward beveling of the greensand marl by erosion is perhaps shown by the following record:

Record of well of H. J. Heinz Co. at locality 7, Salem.

[Fenwick Creek, about 0.35 mile N. $42^{\circ} \mathrm{W}$. of railroad station. Elevation, about 3 feet. C. C. Hulladay, driller and informant.]

\begin{tabular}{|c|c|c|c|}
\hline & $\begin{array}{l}\text { Thick- } \\
\text { ness. }\end{array}$ & Depth. & Formation. \\
\hline Grey.......... & $\begin{array}{r}\text { Feet. } \\
8 \\
3\end{array}$ & $\begin{array}{r}\text { Feet. } \\
8 \\
11\end{array}$ & \multirow{2}{*}{$\begin{array}{l}\text { Pleistocene. } \\
\text { Hornerstown and Nav- } \\
\text { esink (?). } \\
\text { Do. } \\
\text { Do. }\end{array}$} \\
\hline 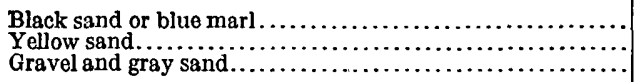 & $\begin{array}{r}6 \\
53 \\
5\end{array}$ & $\begin{array}{l}17 \\
70 \\
75\end{array}$ & \\
\hline
\end{tabular}

If the green and blue marl of the above record are undisturbed a diminution of 26 to 31 feet in the thickness of the marl has occurred between localities 6 and 7. The overburden also has been reduced from 20 or 30 feet to only 8 feet. The thick yellow sand and the gravel in the lower part of the hole suggest that the entire mass of the material penetrated by the well may be Pleistocene and may represent filling in the formerly more deeply eroded valley of Fenwick Creek. Present data are insufficient to determine this point.

A 40-foot well drilled by Haines Bros. for Howard Harris ${ }^{5}$ about 1 mile west of Salem penetrated only fine yellow sands to a point near the bottom, where the color changed to white. These sands are probably Pleistocene. This well is cited merely to show the thickness of Pleistocene overburden that may be expected along the lower course of Salem Creek and in low-lying lands near the Delaware.

A well at Moores Corner, about 1.2 miles south of the courthouse at Salem, shows the continuance of thick beds of marl along the strike, but it shows also the increase in overburden toward the southeast. The record follows:

Record of well of Frank Brown at locality 8, Moores Corner. [Opposite fork and about 100 feet east of road. Elevation, about 11 feet; depth, 120 feet. C. C. Holladay,

\begin{tabular}{|c|c|c|c|}
\hline & $\begin{array}{l}\text { Thick- } \\
\text { ness. }\end{array}$ & Depth. & Formation. \\
\hline 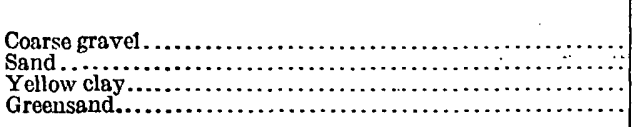 & $\begin{array}{c}\text { Feet. } \\
4 \\
3-4 \\
32 \pm \\
25-30\end{array}$ & $\begin{array}{r}\text { Fect. } \\
4 \\
8 \\
40 \\
70\end{array}$ & $\begin{array}{l}\text { Pleistocene. } \\
\text { Do. } \\
\text { Do. } \\
\text { Hornertown and Nav- }\end{array}$ \\
\hline Black sand, water bearing............... & 50 & 120 & $\begin{array}{l}\text { Mount Laurel and We- } \\
\text { nonah? }\end{array}$ \\
\hline
\end{tabular}

${ }^{\circ}$ New Jersey Geol. Survey Ann. Rept. for 1901, p. 105, 1902.

$88625^{\circ}-22-3$ 
Southeast of the area mapped as Vincentown three additional borings throw light on the thickness and character of the overburden in that district.

A well drilled for Dr. Hummel at Sandy Ridge farm (locality 9), about 1 mile $\mathrm{N} .42^{\circ} \mathrm{W}$. of the Quinton railroad station, shows, according to C. C. Holladay, driller, 36 feet of overburden and 23 feet of "light-colored marl." This marl may be Vincentown, but it lies within the area mapped by the State Geological Survey as Kirkwood and may represent a marly phase of that formation, which farther southeast is known as the Shiloh marl member of the Kirkwood formation, and was formerly dug as a fertilizer. ${ }^{6}$

A well near Hagerville gives the following record:

Record of well of James Pettit at locality 10, about half a mile southeast of Hagerville.

[South side of road. Elevation, $5 \pm$ feet. C. C. Holladay, driller and informant.]

\begin{tabular}{|c|c|c|c|}
\hline & $\begin{array}{c}\text { Thick- } \\
\text { ness. }\end{array}$ & Depth. & Formation. \\
\hline 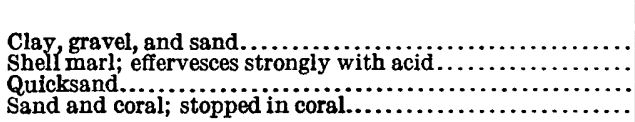 & $\begin{array}{r}\text { Feet. } \\
17 \\
10 \\
58 \\
15\end{array}$ & $\begin{array}{r}\text { Feet. } \\
17 \\
27 \\
85 \\
100\end{array}$ & $\begin{array}{l}\text { Pleistocene. } \\
\text { Kirkwood (?). } \\
\text { Do. } \\
\text { Vincentown (?). }\end{array}$ \\
\hline
\end{tabular}

It is supposed that the upper bed of marl in this well may represent the Shiloh marl member and the lower bed the lime sand or Vincentown. Upon this assumption the Hornerstown marl at locality 10 will lie 110 feet or more beneath the surface.

The well of Jerry Powell, on the west bank of Hope Creek near its mouth (locality 11), "a stone's throw from the Delaware," is said by C. C. Holladay, driller, to be 264 feet deep. The greensand is 40 feet thick and 200 feet below the surface. Water is obtained from a yellow sand beneath the marl. The marl is very compact.

Two wells about $2 \frac{1}{4}$ miles east of Alloway on the road to Daretown show the increase in depth of the marl beds in the direction of the dip. One well is on the farm of Parvin Lloyd and the other on the farm owned by Samuel C. Reeve and occupied by Henry Hile. Both wells are at an elevation of about 40 feet. Woolman ${ }^{7}$ presents the following combined record:

- Cook, G. H., Geology of New Jersey, pp. 471-473, 1868.

:Woolman, Lewis, Artesian wells: New Jersey Geol. Survey. Ann. Rept. for 1901, p. 102, 1902. 
Combined record of two wells 21 miles east of Alloway.

[No. 1: Elevation, 40 feet; depth, 240 feet; driller, Abraham Darlington. No. 2: Elevation, 30 feet; depth, 205 feet; drillers, Haines Bros.]

\begin{tabular}{|c|c|c|c|}
\hline & $\begin{array}{l}\text { Thick- } \\
\text { ness. }\end{array}$ & Depth. & Age or formation. \\
\hline 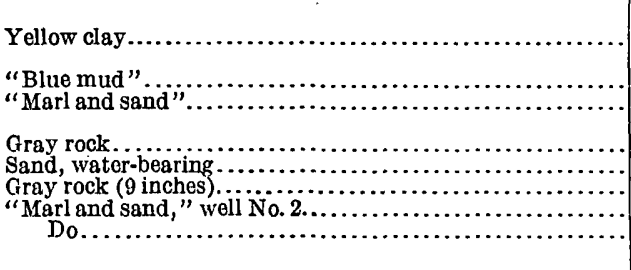 & $\begin{array}{r}\text { Feet. } \\
18 \\
90 \\
72 \\
71 \\
81 \\
1 \\
14 \\
35\end{array}$ & $\begin{array}{r}\text { Feet. } \\
18 \\
108 \\
180 \\
1812 \\
190 \\
191 \\
205 \\
240\end{array}$ & $\begin{array}{l}\text { Miocene in part at } \\
\text { least. } \\
\text { Mostly lime sands } \\
\text { [Vincentown]. } \\
\text { Do. } \\
\text { Do. } \\
\text { Do. } \\
\text { Middle marl. } \\
\text { [Hornerstown and } \\
\text { Navesink]. }\end{array}$ \\
\hline
\end{tabular}

The thickness of the lime sand here is noteworthy, as is also the thickness of the marl, which lies 191 feet below the surface.

Record of well of Salem Water Co. at Quinton. ${ }^{a}$

[Depth, 248 feet; Kisner \& Bennett, drillers.]

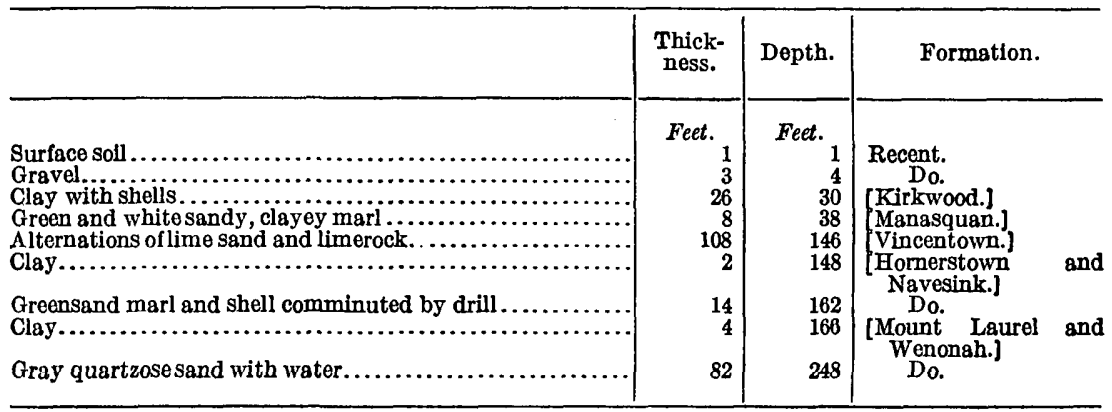

a New Jersey Geol. Survey Ann. Rept. for 1894, p. 194, 1895.

In the above record the formation names in brackets are substituted by the writer for those used in the report cited. The thickness of the lime sand (108 feet) is remarkable. The thickness of the combined Hornerstown and Navesink is rather low.

oterer data.

The exposures of the three important marl beds nearest to Salem occur along Mannington Creek and its tributary Swedes Run in Mannington Township, from 3 to 5 miles northeast to nearly east of Salem. The limestone phase of the Vincentown sand is also exposed at the same locality. These formations were dug and utilized as fertilizer years ago, and analyses of samples from them are given by Cook. ${ }^{8}$ 
IIME SAND.

The use of lime in extracting potash from greensand lends interest to the occurrences of the lime-sand and limestone phases of the Vincentown sand as possible sources of the lime. The following analyses given by Cook show the character of this material:

Analyses of limestone and lime sand from the Vincentown sand in Mannington Township.a

\begin{tabular}{|c|c|c|c|c|c|c|c|}
\hline & 1 & 2 & 3 & . & 1 & 2 & 3 \\
\hline \multirow[t]{2}{*}{$\begin{array}{l}\text { Phosphoric acid.......... } \\
\text { Sulphuric acid } . \ldots \ldots \ldots \ldots \\
\text { Silicic acid................. } \\
\text { Magnesia................ }\end{array}$} & \multirow[t]{2}{*}{$\begin{array}{r}0.04 \\
.06 \\
23.31 \\
1.81\end{array}$} & \multirow[t]{2}{*}{$\begin{array}{r}0.20 \\
.23 \\
8.11 \\
1.40\end{array}$} & \multirow[t]{2}{*}{$\begin{array}{r}43.40 \\
1.95\end{array}$} & \multirow{2}{*}{ 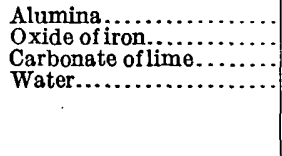 } & $\begin{array}{r}0.91 \\
3.07 \\
69.61 \\
\quad .24\end{array}$ & $\begin{array}{r}0.86 \\
3.56 \\
84.73 \\
.45\end{array}$ & $\begin{array}{r}6.20 \\
44.45 \\
\ldots \ldots \ldots\end{array}$ \\
\hline & & & & & 99.05 & 99.54 & 96.00 \\
\hline
\end{tabular}

a Cook, G. H., op. cit., pp. 441-442.

No. 1 is described as a fair sample of the "Yellow limestone" in Mannington Township. No. 2 is described as lime sand from pits of John Fowler, Swedes Bridge, Mannington Township. This is a sample of the loose variety, is gray in color, and contains many greensand grains. No. 3 is described as lime sand from William Barber's pits, along a branch of Mannington Creek, Mannington Township. This lime sand was extensively used as a fertilizer. The stony layers were burned for lime, which had a wide use and gave good satisfaction.

These pits have long been idle and have probably passed into other ownership, but the general locality can readily be identified from the map. The average content of carbonate of lime for the three samples is 66.3 per cent. The low magnesia content is noteworthy. Measurements of thickness are not now available, but the former use of the lime sand suggests its presence in commercial quantity. Cook ${ }^{8}$ writes: "William Barber's yellow limestone quarry is perhaps the finest in the State; he has dug 25 feet in it without finding bottom; it is made up of alternating tabular masses of limestone and lime sand, the stone from 4 to 12 inches thick and the sand from 8 inches to 2 feet thick."

The Shiloh marl, to which reference has already been made, was dug on branches of Stow Creek along the county line, about 9 miles southeast of Salem. The five analyses given by Cook ${ }^{10}$ show a maximum content of about 15 per cent of carbonic acid $\left(\mathrm{CO}_{2}\right)$, equivalent to 32 per cent of carbonate of lime. These analyses show a maximum of 2 per cent of phosphoric acid and of 1.55 per cent of potash and soda combined. 
ESTIMATES OF TONIAGE AND VALUE.

At locality 1 the thickness of the marl sampled was 23.3 feet. At locality 3 the thickness sampled was 15.5 feet, but the marl at this locality was not penetrated. The average of the thicknesses sampled is 19.4 feet, but for purposes of computation it may safely be assumed as 20 feet. The average potash content, weighted according to the thicknesses represented by the respective samples, is 6.62 per cent. The weight per cubic foot of marl, on the assumption of 28 per cent of voids, as explained in a previous paragraph, is 133 pounds. On this basis 1 acre would contain $\frac{43,560 \times 20 \times 133 \times 0.0662}{2,000}=3,800$ tons of potash (approximately), and 2.5 acres would contain 9,500 tons.

With an 80 per cent recovery and a price of $\$ 2.50$ per unit (March, 1920), the available potash in a ton of greensand from the localities sampled (6.62 per cent $\mathrm{K}_{2} \mathrm{O}$ ) would be worth $\$ 13.24$ and that in an acre $\$ 760,000$. It is doubtful, however, if the price of potash can be maintained at that figure. At $\$ 1.50$ per unit under the same conditions the available potash in a ton of greensand would be worth $\$ 7.94$, and that in an acre $\$ 456,000$. These values have only theoretical interest; as they depend upon the potash being made available by processes whose success has not been demonstrated.

Although the estimates given are for a single area of 2.5 acres the well records cited show that greensand marl occurs generally beneath the Salem area. The wells at localities 5, 6, and 8 show thicknesses of greensand ranging from 25 to 40 feet. These wells, as also the borings at localities 1 and 3 , are near the southeastern border of the beveled greensand belt, where the thickness is greater. Toward the northwest the thickness may be presumed to diminish to zero along the general northwestern border of the belt.

UTILIZATION OF THE DEPOSITS.

The record of the well at locality 7 appears to show that the overburden may not be as thick along Fenwick Creek as elsewhere in the Salem district. On the other hand, the marl shown in that record may be reworked material of Pleistocene age and if so may have a lower percentage of potash than the undisturbed Cretaceous deposits. Systematic prospecting along the creek would be necessary to settle these uncertainties.

Elsewhere the overburden in the Salem district appears to be too thick to permit any immediate utilization of the greensand in the Hornerstown and Navesink marls, but the deposit may be regarded as a resource of possible future value. 


\section{WOODSTOWN DISTRICT.}

\section{SELECTION AND LOCATION OF SITES.}

Considerable marl reported as of good quality was dug in the vicinity of Woodstown in the early days, and the material is still readily accessible, as is also the lime sand, which occurs in several stream valleys near the town. Railroad transportation is available, and Salem Creek has been reported as navigable below Sharptown. It is now utilized as far up as Course's Landing. Woodstown thus seems a favorable place for commercial development of the marl.

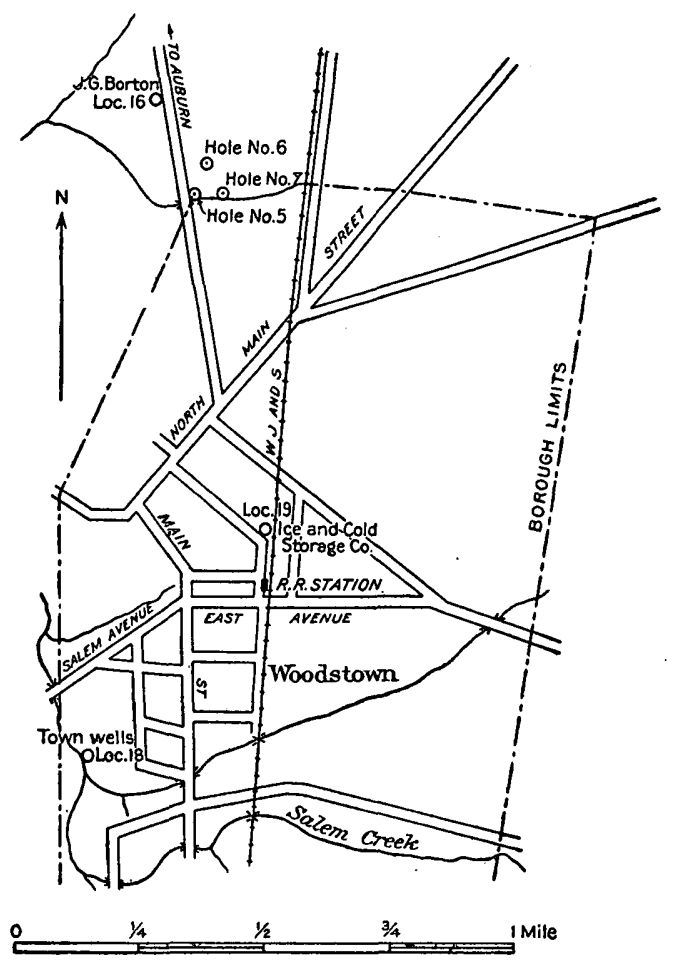

Figure 3.-Sketch map of part of the Woodstown district, showing the locations of holes 5 to 7 and of certain wells near Woodstown.

The site selected is a field belonging to Isaac $\mathrm{K}$. Lippincott, at the north boundary of the borough, east of the road between Woodstown and Auburn, as shown in figure 3. 
HOLES 5 TO 7.

\section{Three holes were sunk in an area of $2 \frac{1}{2}$ acres; their records follow:}

\section{Records of holes in Woodstown district.}

Locality 12, hole 5 .

[Field of Iśac K. Lippincott, about 1 mile north of Woodstown station, 20 feet east of culvert on road to Auburn, on north side of creek. Elevation of surface about 48 feet. S. J. Taylor, driller; R. K. Bailey, analyst.]

Soil, grayish to brownish, clayey, with some sand and grass roots; scattered quartz pebbles as large as 1 inch in diameter.

Clay, sandy, with pebbles larger and more numerous than above; some lumps of greensand.

Sand, yellow, with larger proportions of greensand and some pebbles.

Sand, yellow, becoming greenish with increasing proportion of glauconite, few if any pebbles; grades downward into glauconite beds.

Glauconite beds with considerable greenish-gray clay and fine quartz particles. Some scattered pebbles more than inch in diameter. and some gravelly material possibly worked down by sticking of pipe.

Glauconite beds containing some fine sand..... Glauconite beds, dark greenish gray, compact, clayey, plastic.

Glauconite beds, somewhat coarser; include a few grains of quartz and chert about 1 inch in diameter and a fow pieces of shell. At 22 feet material becomes runny. Two small pebbles noted.

Glauconite beds with considerable light-green clay, more firm. Lowest 1 foot contains fragments of shell and some quartz grains.

Glauconite beds, with much drab-gray clay, little or no quartz. At 32 feet material becomes soft and tends to run. At 33 feet 8 inches chocolate-colored clay pellets appear in glauconite material, also scattered coarse grains of quartz.

Glauconite beds with much gravel, considerable drab clay and some shell fragments; waterbearing.

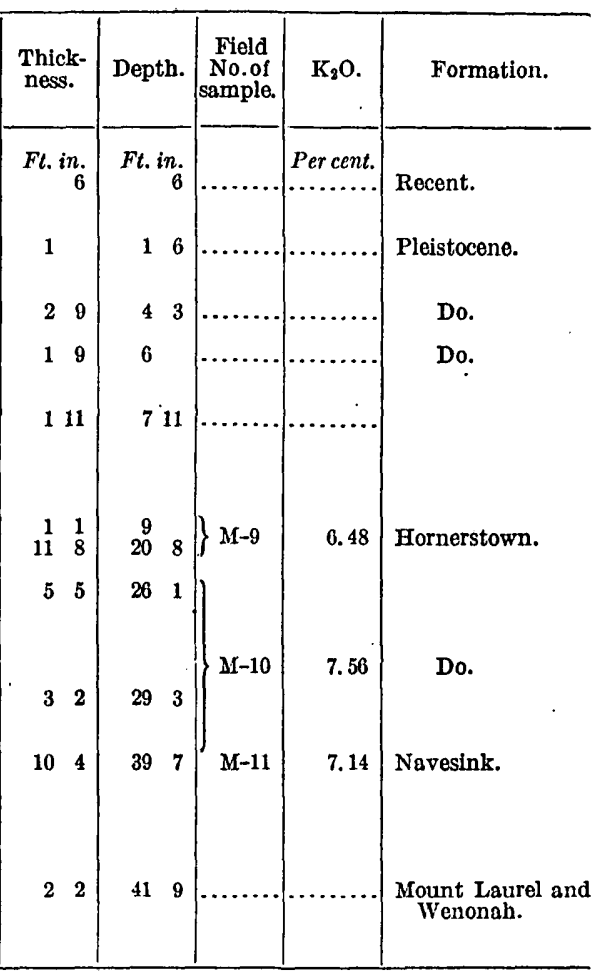


Locality 13, hole 6.

[Field of Isaac K. Lippincott, Woodstown, 375 feet N. $30^{\circ}$ E. from hole 5. Elevation of surface about 53 feet. S. J. Taylor, driller; R. K. Bailey, analyst.]

Top soll, dark, clayey, with some sand.

Clay, sandy, grayish.

Gravel yellow, in matrix of sand and ciay.

quartz pebbles as large as 21 inches in diameter.

Glauconite beds, stiff, with dark-greenish to

black clay, containing some small rounded quartz pebbles inch in diameter. One smooth ovate pebble noted at bottom.

Glauconite beds, clayey, homogeneous, with somewhat larger proportion of black glauconite.

Glauconite beds similar to above but including at base a few inches of underlying stratum.

Glauconite beds with greenish-drab clay, much intermingled quartz sand, and yellow grains probably of weathered ferruginous chert: coarser grains of clear and yellow-stained quartz and chert as large as 1 inch in diameter, angular and rounded; runs into pipe, water bearing; not sampled.

Glauconite beds, black, clayey, viscous, apparently uniform. (Sample $M-14=2$ feet of material from 21 feet 10 inches to 23 feet 10 inches.)

Glauconite beds, green, larger proportion of glauconite; runs easily; uniform character sample bailing taken at depth of 29 feet. One fish tooth observed.

Glauconite beds, green, greater proportion clay, stiff, fine textured, apparently uniform. Sample M-16 represents material from depth of 30 to 31 feet.

Glauconite beds, less clayey, green material with larger proportion of glauconite, fine texture, soft: tends to run. Sample M-17 taken from a bailing at depth of 34 feet 7 inches but apparently representative of entire thickness.

Glauconite beds, brownish black, comparatively littleclay. Sample M-18 taken from a bailing at depth of 40 feet but considered representative of entire thickness.

Glauconite beds, brownish black, containing gravel, sand, clay, and much glauconite Gravel grains $\frac{1}{16}$ to inch in diameter; some of clear quartz, angular; others rounded and composed of quartz and chert. Chocolato-colored clay pellets $\frac{1}{2}$ to $\frac{1}{2}$ inch in diameter also present. Some of gravel grains smooth and polished ("rice gravel")

("rice gravel"). quartz sand but less clay and glauconite.

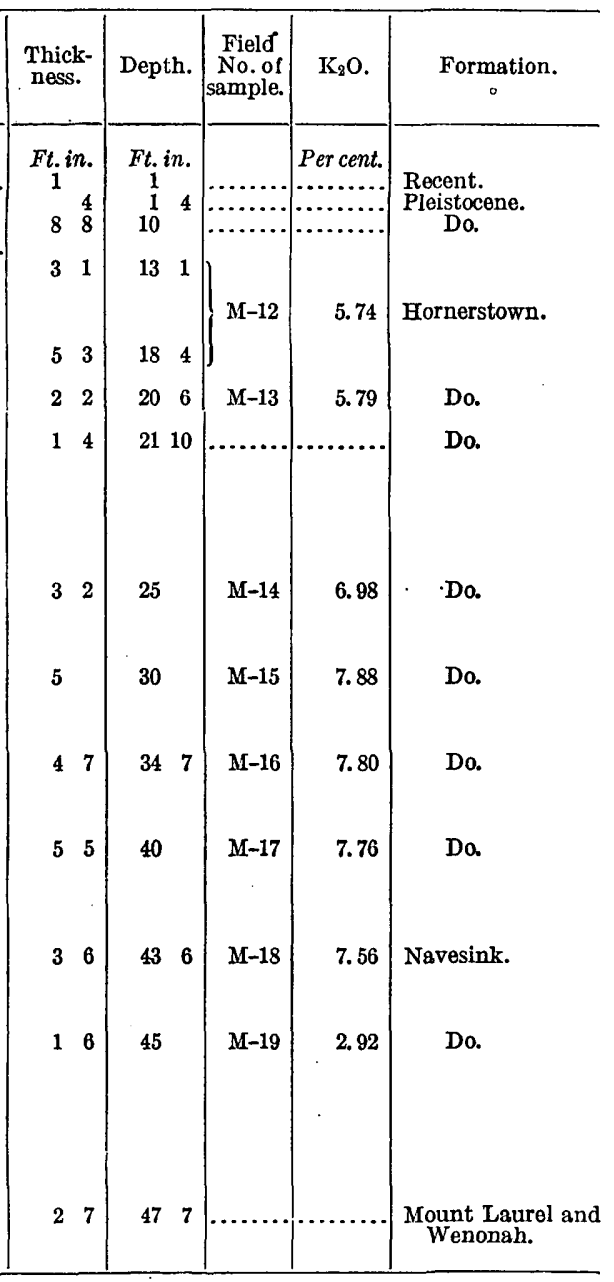


Locality 14, hole 7 .

[Field of Isaac K. Lippincott, Woodstown, 330 feet S. $83^{\circ} \mathrm{E}$. from hole 5 . Elevation of surface about 50 feet. S. J. Taylor, driller; R. K. Bailey, analyst.]

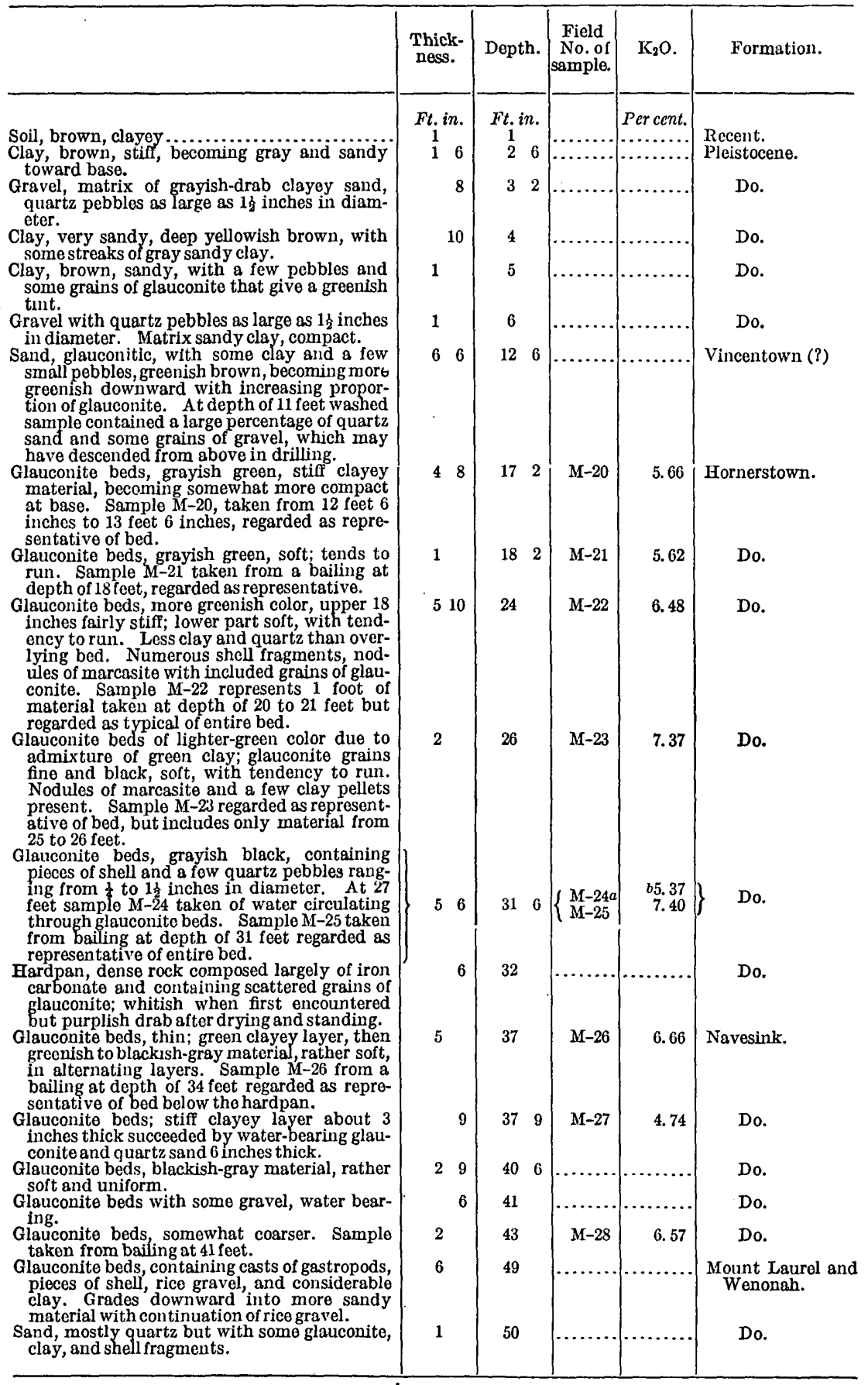


The data of holes 5 to 7 are summarized in the following table:

Thickness and quality of greensand beds at holes 5 to 7 , Woodstown.

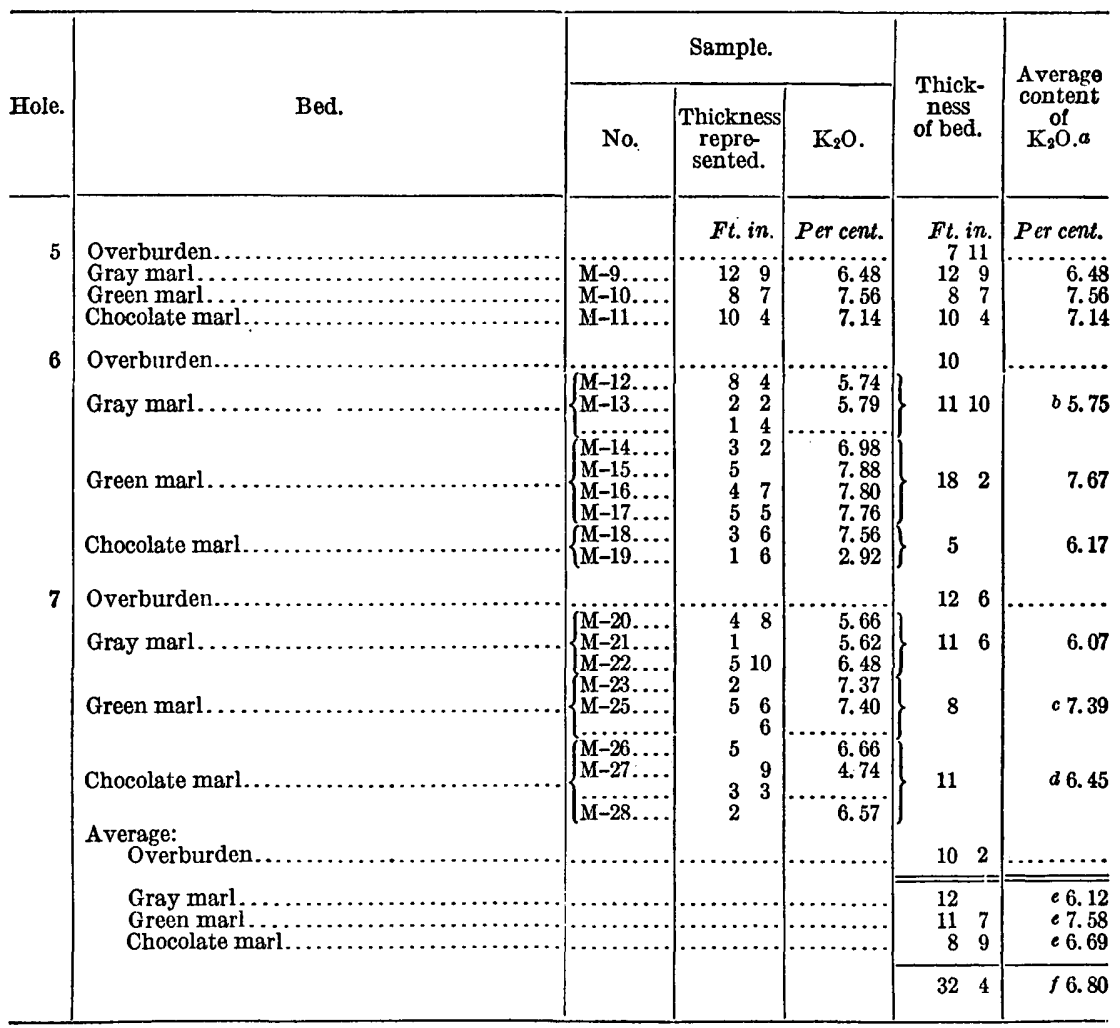

a Average for bed weighted according to the thicknesses represented by the respective sampies.

$b$ Average for 10 feet 6 inches.

c Average for 7 feet 6 inches.

d Average for 7 feet 9 inches.

Average for bed in 2.5-acre tract weighted according to thickness at the respective holes.

$f$ Average for entire thickness of marl in the 2.5-acre tract.

\section{WELL DATA.}

A number of wells drilled in the vicinity of Woodstown furnish supplementary data regarding the thickness of the overburden and of the marl. Three of these wells (at localities 15 to 17) were sunk during the field investigation by the Survey party.

\section{Record of well of Joseph Allen at locality 15, near Woodstown.}

[Well is 1.1 miles S. $84^{\circ} \mathrm{W}$. of railroad station, on north side of road. Elevation, about 50 feet; diameter, 6 inches; depth, 105 feet. Joseph Allen, informant; C. C. Holladay, driller.]

\begin{tabular}{|c|c|c|c|}
\hline & $\begin{array}{l}\text { Thick- } \\
\text { ness. }\end{array}$ & Depth. & Formation. \\
\hline $\begin{array}{l}\text { Overburden largely yellowish-gray clay with some gravel; } \\
\text { white quartz pebbles as much as } 1 \text { inch in diameter on } \\
\text { dump. }\end{array}$ & Feet. 13 & Feet. & Pleistocene. \\
\hline 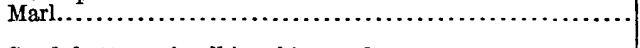 & 58 & 71 & $\begin{array}{l}\text { Vincentown (?) to } \\
\text { Navesink. }\end{array}$ \\
\hline Sand; bottom of well in white sand $\ldots \ldots \ldots \ldots \ldots \ldots \ldots \ldots$ & 34 & 105 & $\begin{array}{l}\text { Mount Laurel and } \\
\text { Wenonah. }\end{array}$ \\
\hline
\end{tabular}


Although the shell bed at the top of the Hornerstown is not present in this well it occurs in openings on Mr. Allen's property about 3,500 feet to the southwest. The thickness of the marl seems a little excessive, but the bed was reported as all greensand. Probably some of the glauconitic phase of the Vincentown is included.

A well drilled earlier probably not far from locality 15 shows a somewhat different record.

Record of well of Charles E. Allen, about 1 mile west of Woodstown.a

[On road to Sharptown. Elevation, about 50 feet; depth, 135 feet. Haines Bros., contractors.]

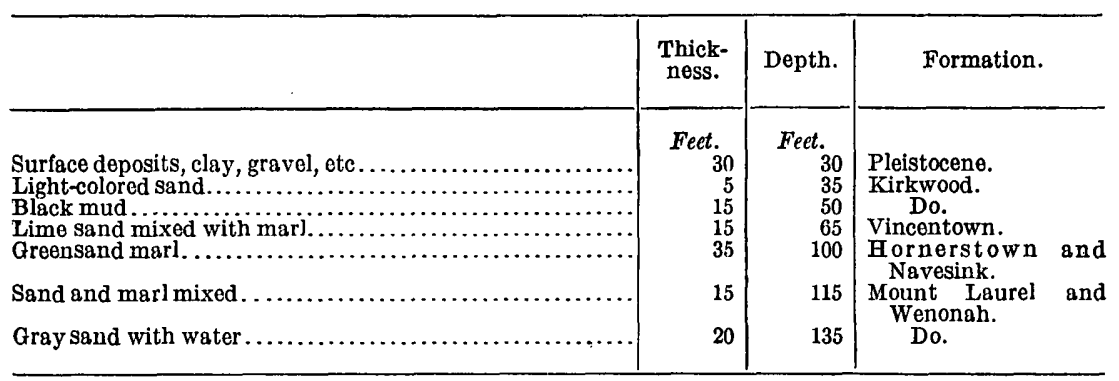

a Now Jersey Geol. Survey Ann. Rept. for 1901, p. 101, 1902.

Record of well of J. Gilbert Borton at locality 16, near Woodstown.

[About 0.21 mile beyond the borough limits of Woodstown, on west side of road to Auburn. Elevation, about 55 feet; diameter, $4 \frac{1}{2}$ inches; depth, 75 feet. Chalkley Haines, driller.]

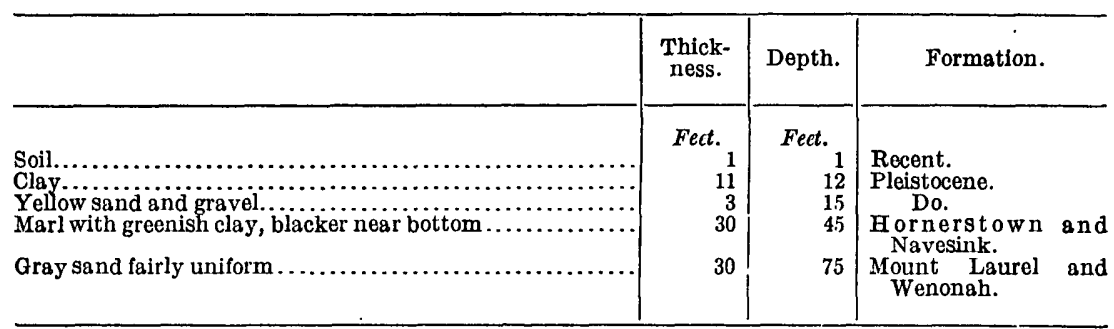

Record of well of William Cole at locality 17, near Woodstown.

[A bout 0.83 mile north of borough limits of Woodstown, on west side of road to Auburn. Elevation, about 68 feet; depth, 30 feet. Chalkley Haines, driller.]

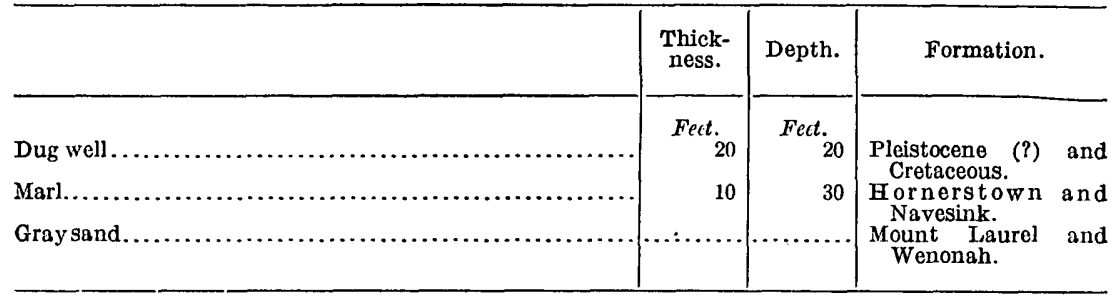

The overburden at locality 17 is probably slight, and most of the well is in greensand marl.

The following notes on the deep wells supplying water to the borough of Woodstown, which were kindly furnished by Dr. Twitchell,11

${ }^{11}$ Twitchell, M. W., unpublished manuscript. 
of the State Survey, will be of interest to any company that proposes commercial development of the greensands:

The town supply of Woodstown, Salem County, is drawn in part from six wells near the bank of the creek at an elevation of about 20 feet and varying from 136 to 149 feet in depth. The average flow of each well from the top of the casing, 1 foot above the surface, is about 60 gallons per minute; temperature $58^{\circ}$. The wells draw from the Mount Laurel-Wenonah sands, which were water-bearing from 60 to 114 feet below sea level. A seventh well at this point was prospected to 776 feet. Waterbearing sands were found at the top of the Magothy-Raritan formation from 276 to 319 feet below sea level and also near the bottom of the series at 756 feet below sea level. Between these two horizons an alternating series of sands and white and red clays was found, all of which apparently belong to the Raritan and Magothy formations, which here have a thickness of 480 feet, with base not reached. The water at 296 feet ( 276 feet below sea level) rose within 14 feet of the surface, and that from 776 feet ( 756 feet below sea level) within 18 feet. In 1915 a new well was driven to a depth of 340 feet, which drew upon the upper horizon in the Magothy-Raritan at 310 feet. The yield of this deep well on pumping is 300 gallons per minute, and it has therefore proved an important addition to the town supply.

Available records of the 340 -foot well differ somewhat, but the following, taken from a letter in the files of the State Geological Survey, checks fairly well with the samples now preserved at the pumping station and kindly shown to the writer by Mr. Oren Conover, city engineer.

Record of well of Borough of Woodstown at locality 18.

[Elevation, about 20 feet; depth, 340 feet. Haines \& Hollinshead, drillers.]

\begin{tabular}{|c|c|c|c|}
\hline & $\begin{array}{l}\text { Thick- } \\
\text { ness. }\end{array}$ & Depth. & Formation. \\
\hline 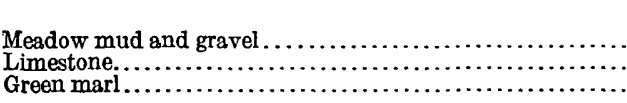 & $\begin{array}{r}\text { Feet. } \\
15 \\
10 \\
40\end{array}$ & $\begin{array}{r}\text { Feet. } \\
15 \\
25 \\
65\end{array}$ & $\begin{array}{l}\text { Quaternary. } \\
\text { Vincentown. } \\
\text { Hornerstown and }\end{array}$ \\
\hline 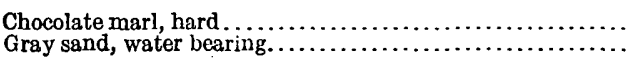 & $\begin{array}{l}10 \\
75\end{array}$ & $\begin{array}{r}75 \\
150\end{array}$ & $\begin{array}{l}\text { Navesink. } \\
\text { Do. } \\
\text { Mount Laurel and Wo- }\end{array}$ \\
\hline Black clay marl. & 160 & 310 & Marshalltown to Mer- \\
\hline White sand and gravel............ & 30 & 340 & Magothy? \\
\hline
\end{tabular}

The samples of material below the marl show some variation from the description in the above record. Samples taken at depths of 185 and 210 feet show a fine-textured micaceous gray clayey sand, containing small pebbles and fragments of shell. These represent the Englishtown sand, which was not utilized. The entire thickness of greensand marl is present, for both shell beds appear to have been penetrated, as indicated by the samples.

Three wells have been drilled for the Ice \& Cold Storage Co., one block north of the depot, at an elevation of 50 feet (locality 19). The writer is indebted to Dr. Twitchell for the following description:

Two of the wells have a diameter of 6 inches, the other of $4 \frac{1}{2}$ inches; the last and one of the 6-inch wells are 160 feet deep and obtain water from the Mount LaurelWenonah sands 50 to 110 feet below sea level-the same horizon which supplies the 
shallower town wells. This water rises within 16 feet of the surface. The other well has a depth of 360 feet and draws from a water-bearing sand at the top of the Magothy 270 to 310 feet below sea level; the water rises within about 50 feet of the surface. The Englishtown sand was found at a depth of 190 to 210 feet (140 to 160 feet below sea level) and was slightly water-bearing.

It is evident, therefore, that at Woodstown four water horizons have been recognized, two of which are utilized-in the Mount Laurel-Wenonah sand at 50 or 60 feet below sea level, in the Englishtown sand at 140 feet below sea level, at the top of the Magothy-Raritan beds at 270 to 276 feet below sea level, and in the Raritan beds at 756 feet below sea level.

Although the Vincentown occurs here and is covered by a layer of Kirkwood clay, it is not reported as water-bearing.

The following is the detailed section for the deepest well near the depot. Notes on the fossils found in this boring were published in the annual report for 1901, page 93. The statement that Belemnitella was found at 240 to 250 feet in the Woodbury is regarded as of doubtful accuracy, as this form has never been reported from any of the outcrops of the Woodbury.

\section{Record of well of Woodstown Ice \& Cold Storage Co. at locality 19.}

[Elevation, 50 feet; diameter, 6 inches; depth, 360 feet. Haines Bros., contractors.]

\begin{tabular}{|c|c|c|c|}
\hline & $\begin{array}{l}\text { Thick- } \\
\text { ness. }\end{array}$ & Depth. & Formation. \\
\hline & Feet. & Fect. & \\
\hline Gravel and yellow clay.. & & & Pleistocene. \\
\hline 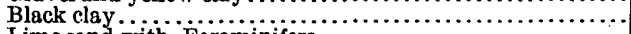 & & 30 & Kirkwood. \\
\hline $\begin{array}{l}\text { Lime sand with Foraminifera } \\
\text { Shell layer containing Gryphaea, Terebratula, and other fossils. }\end{array}$ & $\begin{array}{l}10 \\
10\end{array}$ & $\begin{array}{l}40 \\
50\end{array}$ & $\begin{array}{l}\text { Vincentown. } \\
\text { H ornerstown }\end{array}$ \\
\hline Pure greensand marl, very dark. & 30 & 80 & $\begin{array}{l}\text { Navesink. } \\
\text { Do. }\end{array}$ \\
\hline $\begin{array}{l}\text { Lighter-green greensand marl, mixed with light-gray clay; } \\
\text { contains Belemnites at about } 90 \text { feet. }\end{array}$ & 10 & 90 & Do. \\
\hline $\begin{array}{l}\text { Slightly clayey, dull yellowish-gray sand, about one-third } \\
\text { greensand, two-thirds whitish quartz sand, with Belem- } \\
\text { nites and molluscan fossils. }\end{array}$ & 45 & 135 & $\begin{array}{l}\text { Mount Laurel and We- } \\
\text { nonah. }\end{array}$ \\
\hline $\begin{array}{l}\text { Black and white clear sand; resembles pepper and salt mix- } \\
\text { ture; Belemnitella, Terebratula, and other fossils, etc. } \\
\text { (The last two divisions, from } 100 \text { to } 160 \text { feet, are largely } \\
\text { water bearing throughout and supply wells Nos. } 1 \text { and 2.) }\end{array}$ & 25 & 160 & Do. \\
\hline 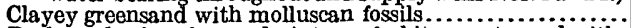 & 10 & 170 & Marshalltown. \\
\hline $\begin{array}{l}\text { Dark sand y clay; large admixture of white quartz sand with } \\
\text { a smaller proportion of greensand; contains mollusks, }\end{array}$ & 20 & 190 & Do. \\
\hline $\begin{array}{l}\text { Greenish-gray sand, consisting of white quartz and green- } \\
\text { sand grains, the formerpredominating. This stratum was } \\
\text { slightly water bearing but was not utilized. These speci- }\end{array}$ & 20 & 210 & Englishtown. \\
\hline $\begin{array}{l}\text { Dark, very slightly greenish micaceous clay with very little } \\
\text { greensand. Gryphaea and Belemnitella at } 240 \text { to } 250 \text { feet. }\end{array}$ & .40 & 250 & Woodbury. \\
\hline $\begin{array}{l}\text { Still darker, almost black micaceous clay with yellowish } \\
\text { pobbles between } 270 \text { and } 290 \text { feet. No fossils observed. }\end{array}$ & 40 & 290 & Do. \\
\hline $\begin{array}{l}\text { Decidedly greenish clay; contains at } 290 \text { to } 300 \text { feet some } \\
\text { mollusen fossils similar to fossils at Lenola, but different } \\
\text { from those observed in the overlying beds. Nodules at } \\
290 \text { to } 310 \text { feet. }\end{array}$ & 40 & 330 & Merchantville. \\
\hline $\begin{array}{l}\text { Medium coarse gray or bluish-white sand, abundantly } \\
\text { water bearing; supplies well No. } 3 \text {. }\end{array}$ & 30 & 360 & Magothy and Raritan. \\
\hline
\end{tabular}

From the above section the dip of the water-bearing formations from their outcrop is as follows: Mount Laurel-Wenonah sand 28 to 30 feet; Englishtown 34 feet; MagothyRaritan $38 \frac{1}{2}$ feet.

In this well, as at the borough wells, the entire thickness of the green-sand marl is penetrated, and 10 feet of the lime-sand phase of the Vincentiown is represented. 
A well about 1 mile southeast of Auburn, on the road to Woodstown, furnishes the following record:

Record of well of Benjamin Cheesman at locality 20, near Auburn.

[Elevation, 100 feet; depth, 301 feet. Water rises within 100 feet of surface. Haines Bros., drillers.]

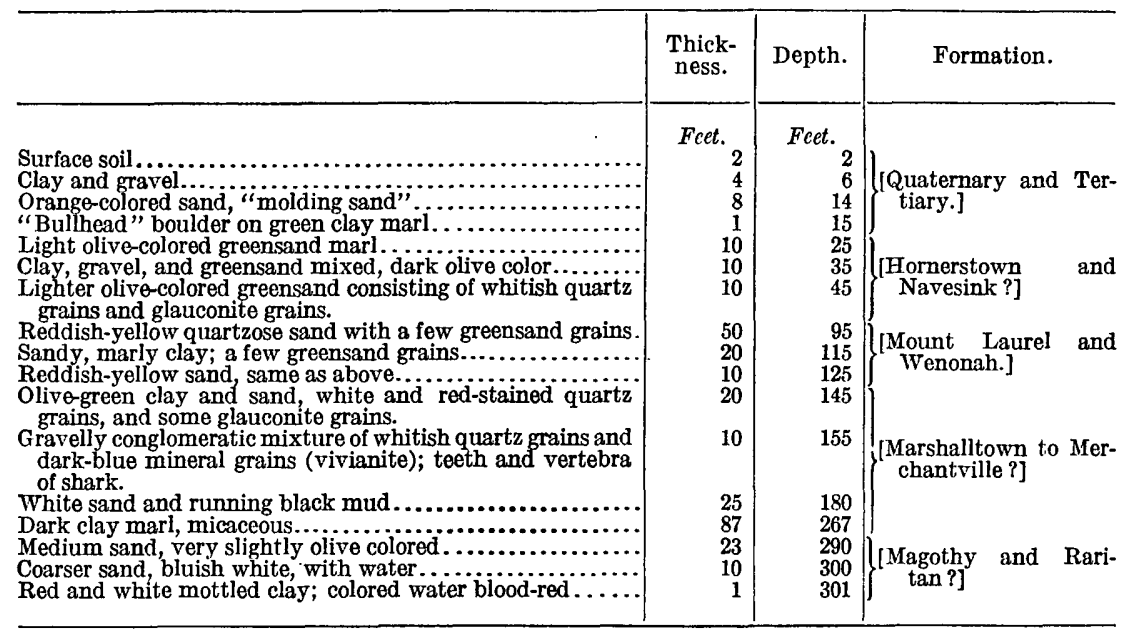

$a$ New Jersey Geol, Survey Ann. Rept. for 1896, pp. 127-128, 1897.

The interpretation of this record is not very clear because of the general distribution of quartzose material. Some of this material from higher beds may have become mixed in drilling with material of lower beds. There seems to be, however, 30 feet of greensand marl overlain by 15 feet of overburden. This locality is about 2 miles from Point Airy railroad station and about 1 mile from Oldmans Creek, which, according to the map, seems large enough to utilize for transportation.

Two wells at Sharptown show similar but not identical records.

Record of well of William Richman at locality 21, Sharptown.

[About 500 feet north of upper bridge over Salem Creek. Elevation, about 10 feet; depth, 136 feet. C. C. Holladay, driller and informant.]

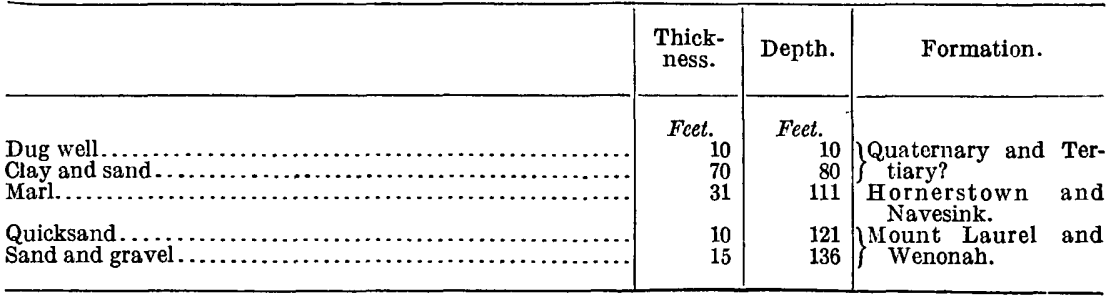


Record of well of Thomas McAllister at locality 22, Sharptown.

[About half a mile N. $29^{\circ}$ W. from upper bridge over Salem Creek, east of road. Elevation, about 52 feet; depth, 155 feet. C. C. Holladay, driller.]

\begin{tabular}{|c|c|c|c|}
\hline & $\begin{array}{c}\text { Thick- } \\
\text { ness. }\end{array}$ & Depth. & Formation. \\
\hline 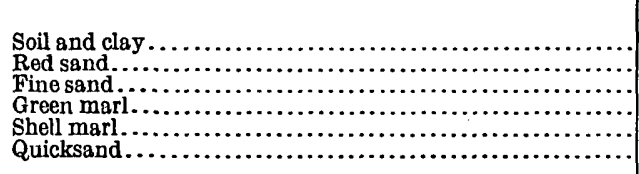 & $\begin{array}{r}\text { Feet. } \\
20 \\
30 \\
20 \\
30 \\
10 \\
45\end{array}$ & $\begin{array}{r}\text { Feet. } \\
20 \\
50 \\
70 \\
100 \\
110 \\
155\end{array}$ & $\left\{\begin{array}{l}\text { Quaternary. } \\
\text { Kirkwood? } \\
\text { Hornerstown and } \\
\text { Navesink. } \\
\text { Mount Laurel and } \\
\text { Wenonah. }\end{array}\right.$ \\
\hline
\end{tabular}

The city wells (locality 18) and those of the Ice \& Cold Storage Co. (locality 19) lie in the Vincentown belt southeast of the greensand marl. The thickness of the greensand penetrated by these wells, 50 feet, may therefore be regarded as the maximum thickness for the district. The holes bored by the cooperating surveys (localities 1214) lie within the greensand belt, near its margin, and show somewhat lower thicknesses, averaging 35 feet. In consideration of the thicknesses at the Sharptown wells (localities 21 and 22; 31 and 40 feet, respectively), this average seems a little low and may indicate a considerable erosion of the greensand at localities 12-14.

\section{OTHER DATA.}

Marl was formerly dug on the north side of Salem Creek about 0.15 mile west of the borough limits. This locality was considered as a drilling site for the present work but was given up because of the thickness of the overburden above the upper beds of marl.

Along Nihomus Run about 1.5 miles northwest of Woodstown (locality 23) the marl was formerly dug and used by many people. The following section was then exposed: ${ }^{12}$

Section of marl beds on Nihomus Run.

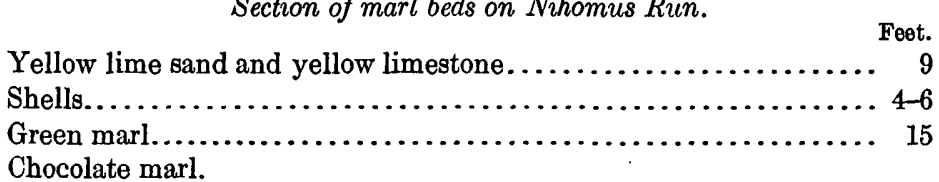

These pits are not now operated, and they lie too far from the railroad to be commercially attractive.

At Oldmans Creek, about 3.5 miles from Woodstown, below the bridge on the road between Point Airy and Harrisonville, the lime sand is exposed in an old pit now largely filled with water. This locality is cited by Cook ${ }^{13}$ as a place where the lime sand was well exposed and commonly dug.

12 Cook, G. H., Gealogy of New Jersey, p. 272, 1868; New Jersey Geol. Survey Ann. Rept. for 1886, p. $179,1887$.

${ }^{18}$ Cook, G. H., Geology of New Jersey, p. 273, 1868. 
LIME SAND.

As shown on the map the lime sand beds on Nihomus Run come within about a quarter of a mile of the railroad. At that place they should be somewhat thicker than at the pits farther down the creek, because they are farther back down the dip. They have doubtless been somewhat eroded, but the three measurements given at Nihomus Run and in the wells at localities 18 and 19 show that a thickness of 10 feet or more of lime sand may be expected at Woodstown. No data regarding its quality are available, but inferences may be drawn from its former rather extensive use. The deposits on Salem Creek are crossed by the railroad and are probably the most accessible. At the city wells (locality 18) the lime sand is covered by 15 feet of overburden.

\section{ESTIMATES OF TONNAGE AND VALUE.}

The average thickness of the greensand marl in the 2.5-acre tract, as indicated on page 34 , is about 32 feet. The average potash content, weighted according to the thicknesses represented by the respective samples, is 6.80 per cent. In computing this average the thicknesses employed for holes 6 and 7 were those of which the respective samples were considered representative, as indicated in the records of these holes. Thus in the 2.5-acre tract a bed of greensand 32 feet thick and containing 6.80 per cent of potash $\left(\mathrm{K}_{2} \mathrm{O}\right)$ may be assumed. Here, as in the estimates for the Salem district, the weight of a cubic foot of greensand, 28 per cent being allowed for voids, is assumed to be 133 pounds. Under these conditions an acre at the selected site would contain $\frac{43,560 \times 32 \times 133 \times 0.068}{2,000}=6,300$ tons of potash $\left(\mathrm{K}_{2} \mathrm{O}\right)$, and the 2.5 acres would contain 15,750 tons. On the assumption of a recovery of 80 per cent and a price of $\$ 2.50$ per unit of 20 pounds (March, 1920) the potash in a ton of greensand would be worth $\$ 13.60$, and the quantity in an acre of ground at the selected site would be worth $\$ 1,260,000$. It seems unlikely that the price will long remain so high. At the more probable figure of $\$ 1.50$ per unit the potash in a ton would be worth $\$ 8.16$ and that in an acre would be worth $\$ 756,000$. These values are hypothetical, because the potash must be recovered by processes not yet satisfactorily demonstrated.

The wells at localities 15,18 , and 19 show that a maximum thickness of 50 feet of greensand marl may be expected in the vicinity of Woodstown. Northwestward the thickness diminishes to zero because of the gentle southeasterly inclination of the beds and the beveling effects of erosion. Thus at Woodstown, as at Salem, the greensand in considerable thickness underlies broad areas. The 2.5-acre tract may, in the light of the analyses from other districts, be considered as representative for this district. 
UTIIIZATION OF TEE DEPOSITS.

The overburden in the sample area averages about 10 feet in thickness. Farther east it is undoubtedly thicker. To the west the overburden is irregularly distributed, and its thickness would have to be determined for any given locality but should not be excessive within the area mapped as greensand.

The analyses show that the higher and lowermost beds have somewhat less potash than the middle beds but that practically all are usable. Water stands in the holes within a few feet of the surface and would have to be considered in any plan for mining the greensand.

The railroad offers at present the most feasible means of transportation. The map shows several sites that could be utilized along the railroad from Woodstown northward toward Swedesboro.

Salem Creek below Courses Landing and the canal to the Delaware are now used by barges for general freighting. Between Courses Landing and Sharptown the creek is shallower but might perhaps be used by boats or scows of lighter draft. The hills south of the creek and west of Sharptown apparently afford good thicknesses of marl within reach of water transportation.

\section{MOLTICA HILL.}

The steep bluff just east of the railroad station at Mullica Hill (locality 24) has long been known for its excellent exposure of the basal bed of the Navesink marl and for its numerous fossils. The section (see $\mathrm{Pl}$. VI, $B$ ) is as follows:

Section of Navesink marl near station at Mullica Hill.

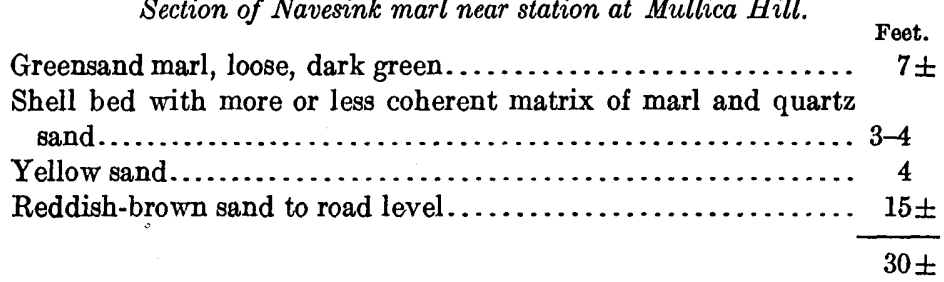

The two lower beds are overwashed with marl from above and are hence dark colored. The veneer of marl may be removed by scraping with the foot and the yellow sands (Mount Laurel) exposed. Many of the shells are as much as 4 or 5 inches in diameter.

Marl was formerly dug at several places near Mullica Hill and was favorably regarded, perhaps because of its relatively high content of phosphoric acid, which, according to two analyses cited by Cook, ${ }^{14}$ ran as high as 3.48 and 3.60 per cent. A sample taken by W. C. Phalen on the Henry Edwards place, 2 miles southwest of Mullica

14 Cook, G. H., Geology of New Jersey, p. 437, 1868.

$88625^{\circ}-22-4$ 
Hill, was analyzed in the laboratory of the United States Geological Survey and found to contain 7.15 per cent of potash. The greensand at this locality is 5 feet or more thick and is overlain by 15 to 20 feet of clay and gravel..$^{15}$ In 1916 some 50 tons of marl was shipped for experimental purposes from the pits of Mrs. E. B. Sharp (locality 25), about 1.15 miles S. $64^{\circ} \mathrm{E}$. of Mullica Hill station. The lime sand also occurs in the same vicinity.

Several localities near Mullica Hill and Jefferson station were visited with the idea of selecting a drilling site, but the overburden in places sufficiently near the railroad proved to be too thick to permit hope of commercial development.

\section{SEWELL DISTRICT.}

The pits near Sewell have long been known for their excellent marl, which was used as a fertilizer. More recently it has been used for experiments in extraction of potash. Excellent railroad facilities are available, and there are extensive areas of relatively even ground in which the overburden does not seem excessive. The actual area drilled at Sewell included only 2.5 acres, but data for a number of localities within a radius of 3 or 4 miles of Sewell are available and may conveniently be discussed in connection with the results of the borings of the cooperating surveys. These localities are therefore included in the Sewell district.

\section{EDWARDS RUN.}

Relatively recent observations by the State geologist on branches of Edwards Run 2 to 3 miles west of Sewell show the exposures described below.

At locality 26 an old marl pit at an elevation of about 70 feet shows the upper part of the combined Hornerstown and Navesink beds.

Section in road cut at locality $2 \%$.

Pleistocene gravel (Bridgeton).

Kirkwood, thin layer. Feet.

Vincentown.................................... 2-3

Terebratula bed, base of Vincentown, elevation 75 feet.

Hornerstown marl.

Section in old pit near ice house at locality 27 , north of road.

Kirkwood formation. . Feet.

Vincentown sand $\ldots \ldots \ldots \ldots \ldots \ldots \ldots \ldots \ldots \ldots \ldots \ldots \ldots \ldots, 5,6$

Hornerstown marl.

At a pit near the pond just north of locality 27 and slightly lower there is a good exposure of Hornerstown marl but no Vincentown.

${ }^{15}$ Ashley, G. H., Notes on the greensand deposits of the eastern United States: U. S. Geol. Survey Bull. 660, pp. 39, 47, 1918. 
Section along road at locality 28.

Pleistocene gravel.

Feet.

Miocene clay, Kirkwood............................. $\quad 2$

Vincentown, more or less marly........................ 5

Terebratula shell bed, elevation about 70 feet.

Hornerstown marl down to flood plain ................. $15 \pm$

These exposures are typical of the partial sections available here and there through the marl belt.

\section{BARNSBORO.}

Several well records give an idea of the thickness of the marl and its overburden near Barnsboro.

\section{Record of well of John Shutes, near Barnsboro.a}

[Elevation, 120 feet; depth, 140 feet; water rises within about 50 feet of surface.]

\begin{tabular}{|c|c|c|c|}
\hline . & $\begin{array}{l}\text { Thick- } \\
\text { ness }\end{array}$ & Depth. & Formation. \\
\hline 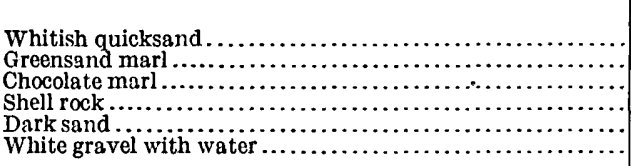 & $\begin{array}{r}\text { Feet. } \\
55 \\
35 \\
15 \\
2 \\
10 \\
23\end{array}$ & $\begin{array}{r}\text { Fcet. } \\
55 \\
90 \\
105 \\
107 \\
117 \\
140\end{array}$ & $\begin{array}{l}\text { [Kirkwood?] } \\
\text { [Hornerstown and Nav- } \\
\text { esink.] } \\
\text { [Mount Laurel and } \\
\text { Wenonah.] }\end{array}$ \\
\hline
\end{tabular}

$a$ New Jersey Geol. Survey Ann. Rept. for 1896, p. 131, 1897.

Record of wells of Dilks Bros., locality 29, near Barnsboro. ${ }^{a}$

[A bout half a mile south of crossroads in Barnsboro; two wells; elevation, about 100 feet; depths, 110 and 170 feet. Haines Bros., drillers.]

\begin{tabular}{|c|c|c|c|}
\hline & $\begin{array}{l}\text { Thick- } \\
\text { ness. }\end{array}$ & Depth. & Formation. \\
\hline 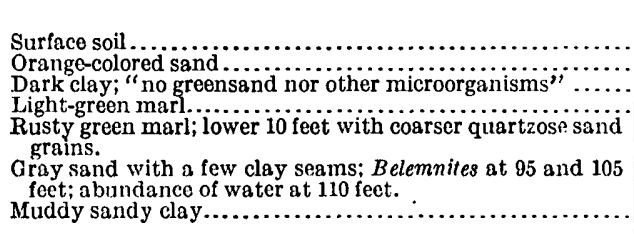 & 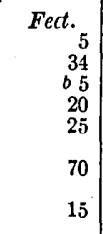 & $\begin{array}{r}\text { Feet. } \\
5 \\
39 \\
b \quad 40 \\
60 \\
85 \\
155 \\
170\end{array}$ & $\left\{\begin{array}{l}{[\text { KKirkwood?] }} \\
{\left[\begin{array}{l}\text { Vincentown(?)to Nav } \\
\text { esink.] }\end{array}\right.}\end{array}\right.$ \\
\hline
\end{tabular}

a New Jersey Geol. Survey Ann. Rept. for 1896, p. 130, 1897.

$\checkmark$ Record evidently erroneous.

J. L. North kindly furnished records for the wells of Charles Dilks and Isaac Dilks, said to be 175 and 135 feet deep respectively. As the two records are similar only the first is given. 
Record of well of Charles Dilks, at locality 29a, three-fourths of a mile south of Barnsboro.

\begin{tabular}{|c|c|c|c|}
\hline & $\begin{array}{c}\text { Thick } \\
\text { ness. }\end{array}$ & Depth. & Formation. \\
\hline 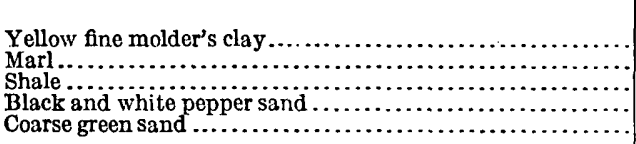 & $\begin{array}{r}\text { Fcet. } \\
40 \\
60 \\
5 \\
\mathbf{3 5} \\
\mathbf{3 5}\end{array}$ & $\begin{array}{r}\text { Fect. } \\
40 \\
100 \\
105 \\
1.10 \\
175\end{array}$ & $\begin{array}{l}\text { Kirkwood (?) } \\
\text { Vincentown (?)to Nav- } \\
\text { esink (?) } \\
\text { Mount Laurel and We } \\
\text { nonah. }\end{array}$ \\
\hline
\end{tabular}

This record differs considerably from the previously published record of the same well given above. It may be noted, however, that the Belemnites, a form characteristic of the basal part of the Navesink, which occurs at 105 feet in the first record, corresponds in position with the base of the shale in the second record, and that in both records marl begins at 40 feet. Either the marl is unusually thick or it includes a glauconitic portion of the Vincentown sand.

Record of well of Dr. W. P. Chalfont at locality s0, Barnsboro.

[Depth, 149 feet. J. L. North, driller and informant.]

\begin{tabular}{|c|c|c|c|}
\hline & $\begin{array}{l}\text { Thick- } \\
\text { ness. }\end{array}$ & Depth. & Formation. \\
\hline 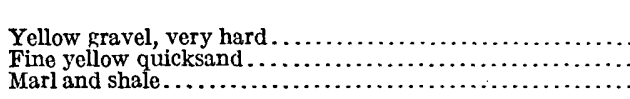 & $\begin{array}{r}\text { Feet. } \\
28 \\
35 \\
50\end{array}$ & $\begin{array}{r}\text { Feet. } \\
28 \\
63 \\
113\end{array}$ & $\begin{array}{l}\text { Pleistocene. } \\
\text { Kirkwood. } \\
\text { Hornerstown and }\end{array}$ \\
\hline 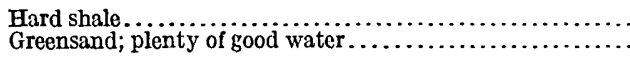 & $\begin{array}{r}30 \\
6\end{array}$ & $\begin{array}{l}143 \\
149\end{array}$ & $\begin{array}{l}\text { Mount Laurel and } \\
\text { Wenonah(?). }\end{array}$ \\
\hline
\end{tabular}

A well at locality 31 , about a quarter of a mile farther west, sunk by J. L. North for James Tomlin, gave a similar record.

Record of well of James Jessup at locality 32, near Barnsboro.a

[About 1 mile northwest of Barnsboro, on road to Mount Royal station. Elevation, 70 feet; depth, 318 feet; water rises within 70 feet of surface. Joseph Pratt, driller.]

\begin{tabular}{|c|c|c|}
\hline & $\begin{array}{c}\text { Thick- } \\
\text { ness. }\end{array}$ & Depth. \\
\hline 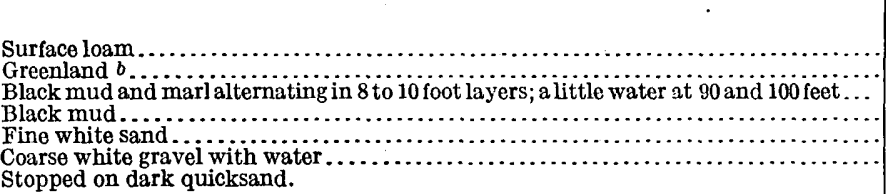 & $\begin{array}{r}\text { Feet. } \\
5 \\
30 \\
80 \\
183 \\
5 \\
15_{2}^{1}\end{array}$ & $\begin{array}{r}\text { Feet. } \\
5 \\
35 \\
115 \\
298 \\
303 \\
318\end{array}$ \\
\hline
\end{tabular}

$a$ New Jersey Geol. Survey Ann. Rept. for 1897, p. 256, 1898.

$b$ The "greenland" is the lower marl, as shown by the occurrence of Belemnites and Exogyra on the banks of a small creek a few hundred feet to the west. 
J. L. North furnishes the following record for the well of James Jessup. The discrepancy between the two records illustrates a difficulty sometimes experienced in trying to procure accurate well data. From either record it is evident, however, that greensand marl in commercial quantity is probably present.

Record of well of James Jessup, near Barnsboro.

[Elevation, $90 \pm$ feet; depth, 333 feet; according to J. L. North, informant.]

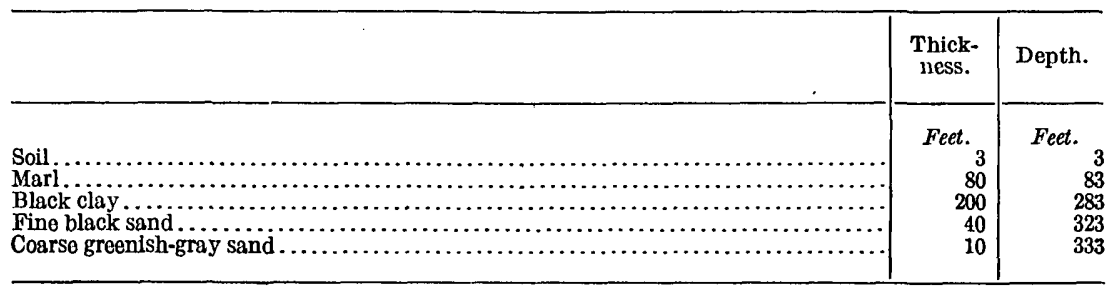

HOLES 8 TO 10.

Three holes, Nos. 8 to 10 , were sunk on the property of the West Jersey Marl \& Transportation Co. east of the railroad track half a mile south of the station. Their location is indicated on the map of the company's property (fig. 4), drawn about 1890 by J. C. Voorhies, secretary, and kindly loaned by him for use in this report. The records of these holes follow. 


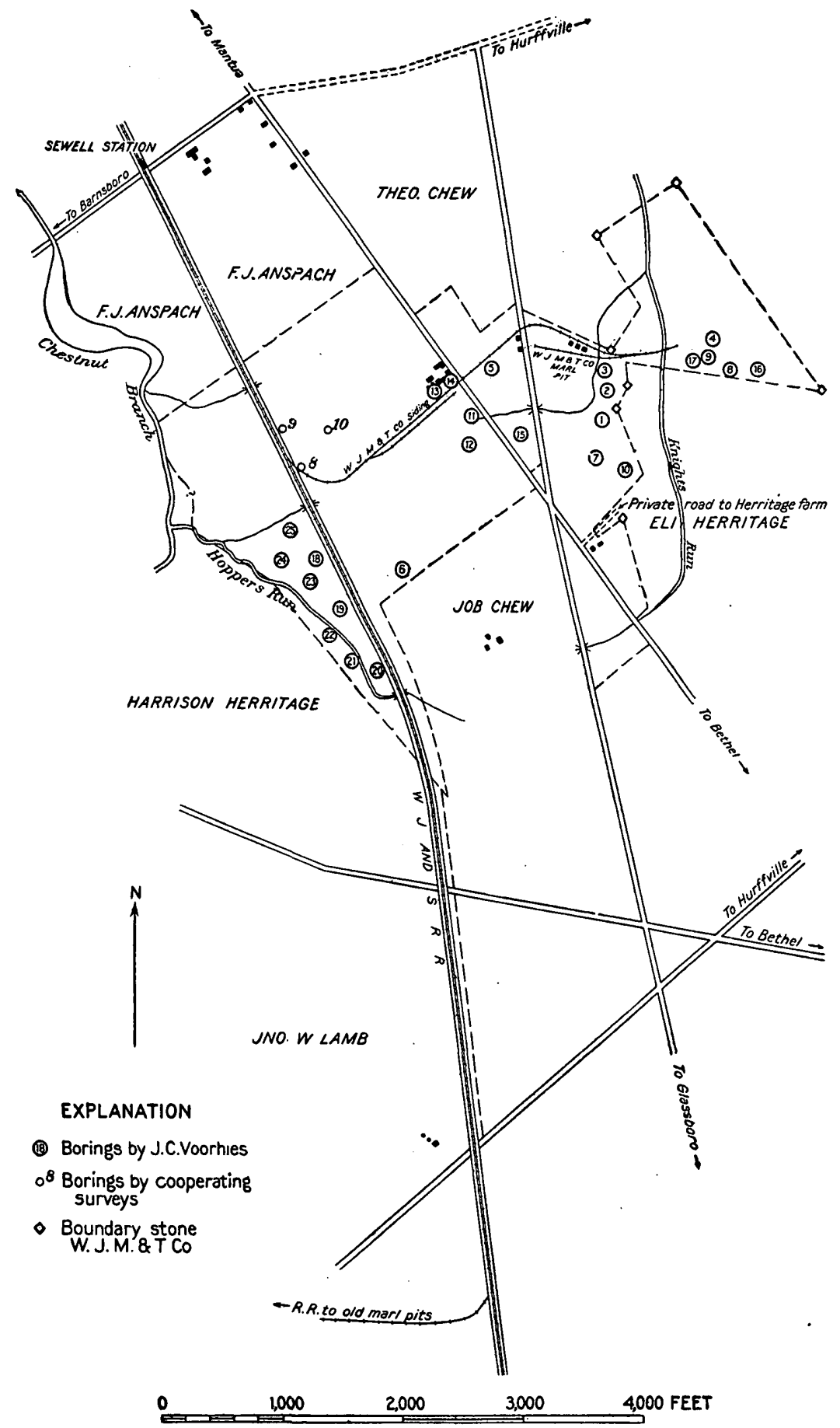

FIGURE 4.-Map of the property of the West Jersey Marl \& Transportation Co. and adjoining property near Sewell station. After J. C. Voorhies. 
Records of holes in Sewell district.

Locality 33 , hole 8 .

[Property of West Jersey Marl \& Transportation Co., at Sewell, 2,750 feet southeast of center line of rallroad station and 40 feet east of center of track. Elevation of surface, about 70 feet. R. K. Bailey, analyst. S. J. Taylor and J. L. North, drillers.]

Top soil, drab-gray sandy clay, with few pebbles. Clay, fine, sandy, grayish buff ut top, with a diameter. Fewer pebbles and deeper-yellow color in lower part.

Sand very fine, very clayey and micaceous, with considerable ocher; finely bedded; white sandy streaks occur in the yellow to deep orange colored material; water bearing at base. Glauconite bed, grayish to olive green and clayey.

Sand composed of quartz and glauconite.

Glauconite beds, grayish green, clayey............

Glauconite beds, yellow olive, very clayey.......

Glauconite beds, olive green, very clayey and

stiff; contain yellow specks of iron oxide. Sample M-31 collected dry in driven cylinder M-32 collected wet in trough as check.

Glauconite beds, very clayey, yellow olive; upper 2 inches contains considerable yellow oxide of iron.

Glauconite beds, blackish to grayish green, with considerable clay.

Glauconite beds like last (?) ...................

Glauconite beds, stiff, with much light-green clay. Material in this interval became mixed with overlying yellowish materlal by accident in driving pipe. This interval therefore excluded from samples.

Glauconite beds, upper part light green and stiff. At about 30 feet become more mealyin texture, with larger proportion of glauconite, and contain a few pieces of shell. Sample M-36 taken by core tool; M-36a, sameinterval, material collected wet as check.

Glauconite beds, similar to above, not sampled.

Glauconito beds, brownish black or chocolatecolored, coarser textured, one rounded pebble half an inch in diameter noted.

Glauconito beds, brown, with some mingling of green; transition beds.

Glauconite beds, chocolate-colored, with some intermingling of green. Sample M-38 taken dry with core tool; M-38a taken wot as check.

Glauconite beds, brownish to black, similar to last, water bearing.

Glauconite beds, similar to last but contain few gravel grains and an increasing proportion quartz sand.

Glauconite beds, black to grayish black; contain considerable quartz sand and the rice gravel but little or no shell.

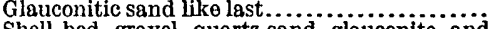

Shell bed, gravel, guartz sand, glauconite, and large pieces of Gryphaea, Erogyra, Belemnitella, concretions of vivianite.

\begin{tabular}{|c|c|c|c|c|}
\hline $\begin{array}{l}\text { Thick- } \\
\text { ness. }\end{array}$ & Depth. & $\begin{array}{c}\text { Field } \\
\text { No. of } \\
\text { sample. }\end{array}$ & $\mathrm{K}_{2} \mathrm{O}$. & Formation. \\
\hline $\begin{array}{c}F_{t} \text { in } \\
1\end{array}$ & $\begin{array}{l}F t . \text { in. } \\
1 \\
2\end{array}$ & & $\begin{array}{l}\text { Percent. } \\
\cdots \\
\cdots\end{array}$ & $\begin{array}{l}\text { Recent. } \\
\text { Pleistocene. }\end{array}$ \\
\hline 810 & 1010 & & 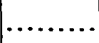 & Kirkwood. \\
\hline & 1011 & & & \\
\hline 11 & $\begin{array}{ll}11 & 1 \\
12 & \end{array}$ & M-29 & 3.54 & Hornerstown. \\
\hline 2 & 144 & $\mathrm{M}-30$ & 4.54 & Do. \\
\hline 11 & 153 & $\left\{\begin{array}{l}M-31 \\
M-32\end{array}\right.$ & $\begin{array}{l}5.99 \\
5.92\end{array}$ & $\begin{array}{l}\text { Do. } \\
\text { Do. }\end{array}$ \\
\hline 43 & 196 & $\mathrm{M}-33$ & 6.70 & Do. \\
\hline 56 & 25 & $\mathrm{M}-34$ & 7.25 & Do. \\
\hline $\begin{array}{l}1 \\
1\end{array}$ & $\begin{array}{l}26 \\
27\end{array}$ & $\begin{array}{l}\mathrm{M}-35 \\
\ldots \ldots \ldots \ldots\end{array}$ & $\begin{array}{c}7.40 \\
\cdots \cdots\end{array}$ & $\begin{array}{l}\text { Do. } \\
\text { Do. }\end{array}$ \\
\hline 5 & 32 & $\left\{\begin{array}{l}M-36 \\
M-36 a\end{array}\right.$ & $\begin{array}{l}7.71 \\
7.36\end{array}$ & $\begin{array}{l}\text { Do. } \\
\text { Do. }\end{array}$ \\
\hline 1 & $\begin{array}{l}33 \\
33\end{array}$ & $\ddot{M}-37^{-}$ & 6.36 & $\begin{array}{l}\text { Navesink. } \\
\text { Do. }\end{array}$ \\
\hline 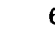 & 34 & $M-37 a$ & 7.62 & Do. \\
\hline 2 & 36 & $\left\{\begin{array}{l}M-38 \\
M-38 a\end{array}\right.$ & $\begin{array}{l}6.41 \\
6.18\end{array}$ & $\begin{array}{l}\text { Do. } \\
\text { Do. }\end{array}$ \\
\hline 5 & 41 & M-39 & 6.88 & Do. \\
\hline 2 & 433 & $M-40$ & 5.59 & Do. \\
\hline 53 & 486 & $M-41$ & 3.51 & Do. \\
\hline 3 & $\begin{array}{ll}48 & 10 \\
49 & 1\end{array}$ & $\cdots \cdots$ & $\ldots$ & $\begin{array}{l}\text { Do. } \\
\text { Do. }\end{array}$ \\
\hline
\end{tabular}


Locality 34, hole 9.

[Property of West Jersey Marl \& Transportation Co., 330 feet N. $20^{\circ} \mathrm{W}$. from hole 8 . Elevation of surface, about 70 feet. R. K. Bailey, analyst. J. L. North, driller.]

Top soil, brownish drab, clayey sand, fine

texture.
Sand clayey, with scattered pebbles $2 \frac{1}{2}$ inches in diameter; matrix very fine textured, with floury feel and yellow color.

Sand, clayey like last, with scattered gravel grains.

Sand, clayey, very fine, micaceous, finely bedded, leafy texture, orange colored, with some white coarser sand infiltered in cracks.

Sand similar to last but light gray...

Glauconite beds, yellowish olive, stiff clayey material, with considerable yellow oxide of iron.

Glauconite beds, deep olive, stiff, clayey, upper 3 or 4 inches oxidized like $M-42$ but remainder with uniform texture and color.

Glauconite bed like last.....................

Glauconite beds, somewhat less clay, more mealy texture, some darker streaks and a few pellets of chocolate-colored clay.

Glauconite beds, distinctly darker, more mealy texture, more nearly pure glauconite grains.

Glauconite beds, dark green to blackish, mealy texture, water bearing in lower part.

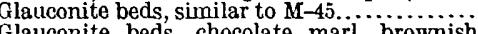
drconith oreenish tint transition beds; considerable clay with scattered ferruginous particles and ferruginous masses, probably pieces of replaced shell.

Glauconite beds similar to $\mathrm{M}-47$ but without the greenish tint, brownish black, stiff clayey -material.

Glaucontte beds similar to $\mathrm{M}-48$ but containing greenish streaks.

Glauconite beds similar to $M-49$............. considerable quartz sand and somesmall grave Glauconite beds like last but with pieces of shell and broken casts composed of glauconitic material, rice gravel.

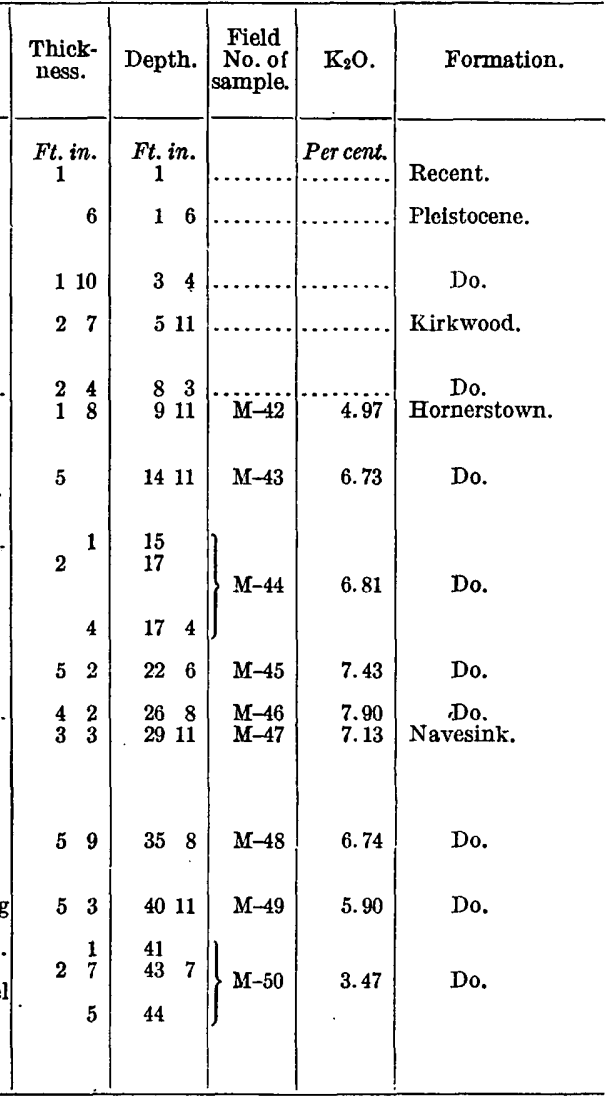


Locality 35, hole 10 .

[Property of West Jersey Marl \& Transportation Co., about 375 feet N. $44^{\circ}$ E. from hole 8 . Elevation of surface about 69 feet. R. K. Bailey, analyst. J. L. North, driller.]

\begin{tabular}{|c|c|c|c|c|c|}
\hline & $\begin{array}{l}\text { Thick- } \\
\text { ness. }\end{array}$ & Depth. & $\begin{array}{l}\text { Field } \\
\text { No. of } \\
\text { sample. }\end{array}$ & $\mathrm{K}_{2} \mathrm{O}$. & Formation. \\
\hline Top soil, brown loam. & Ft. in. & Ft. in. & & Percent. & Recent \\
\hline $\begin{array}{l}\text { Gravel, at first scattered pebbles in light-yellow } \\
\text { matrix of clayey sand, then darker-yellow } \\
\text { coarser sand with pebbles as large as } 2 \text { inches } \\
\text { in diameter, water bearing. }\end{array}$ & 211 & 37 & & ( & Pleistocene. \\
\hline $\begin{array}{l}\text { Sand, yellow and gray banded, fine textured, } \\
\text { clayey and micaceous, becoming purplish in } \\
\text { lower } 6 \text { inches. }\end{array}$ & 41 & 78 & & $\cdots$ & Kirkwood. \\
\hline $\begin{array}{l}\text { Glauconite beds, blackish green, rather stiff } \\
\text { with clay, no oxidized layer or olive- } \\
\text { green bed as at holes } 8 \text { and } 9 \text {. Three pebbles } \\
\text { discarded as having probably followed down } \\
\text { pipe. }\end{array}$ & 1 & 88 & $\mathbf{M}-\mathbf{5 1}$ & 3.83 & Bornerstown. \\
\hline $\begin{array}{l}\text { Glauconite beds, deep bluish to grayish green, } \\
\text { less clay than } \mathrm{M}-51 \text {. }\end{array}$ & 64 & 15 & $\mathrm{M}-52$ & 6.60 & Do. \\
\hline $\begin{array}{l}\text { Glauconite beds, dark or grayish green, mealy } \\
\text { textured, similar to } \mathrm{M}-52 \text { but lower } 6 \text { inches } \\
\text { lighter green. }\end{array}$ & 5 & 20 & $\mathrm{M}-\mathbf{5 3}$ & 7. 63 & Do. \\
\hline Glauconite beds similar to $\mathrm{M}-53 \ldots \ldots \ldots \ldots \ldots$ & & 247 & $M-54$ & 7.52 & Do. \\
\hline $\begin{array}{l}\text { Glauconite beds, chocolate marl, brownish } \\
\text { black with some streaks of green material, } \\
\text { fairly coarse texture but with considerable } \\
\text { clay. }\end{array}$ & 6 & 251 & M-55 & 6.85 & Navesink. \\
\hline $\begin{array}{l}\text { Glauconite beds, chocolate marl } \ldots \ldots \ldots \ldots \ldots . . . . . \\
\text { Glauconite beds similar to } M-56 \text { but contain- }\end{array}$ & $\begin{array}{ll}7 & 4 \\
3 & 3\end{array}$ & $\begin{array}{ll}32 & 5 \\
35 & 8\end{array}$ & M-56 & 6.57 & Do. \\
\hline $\begin{array}{l}\text { ing a few grains of gravel, small marcasite } \\
\text { concretions, and considerable brown clay. }\end{array}$ & & & & 6.90 & Do. \\
\hline $\begin{array}{l}\text { Glauconite beds similar to above but contain- } \\
\text { ing fragments of shell, clay pellets, and some- } \\
\text { what larger proportions of gravel. }\end{array}$ & 9 & 365 & & & \\
\hline $\begin{array}{l}\text { Glauconite beds becoming increasingly sandy. } \\
\text { At base consist of glauconite with quartz sand, } \\
\text { brown clay, concretions, small fragments of } \\
\text { shell, and crystals of vivianite. }\end{array}$ & 12 & 377 & & $\ldots \ldots$ & Do. \\
\hline $\begin{array}{l}\text { Glauconite beds, compact, hard mixture of clay, } \\
\text { quartz sand, and glauconite with gravel } \\
\text { grains. }\end{array}$ & & 40 & & & Do. \\
\hline $\begin{array}{l}\text { Glauconite beds similar to above but somewhat } \\
\text { softer. Rice gravel and quartz sand in in- } \\
\text { creasing proportion. }\end{array}$ & 27 & 427 & & & Do. \\
\hline $\begin{array}{l}\text { Glauconite beds similar to last but with frag- } \\
\text { ments of shell and pepper and salt color. At } \\
\text { base fragments of Belemnitella appear. }\end{array}$ & 5 & 43 & & & Do. \\
\hline
\end{tabular}


For comparison with other borings in the vicinity the data of holes 8 to 10 are summarized in the following table:

Thickness and quality of greensand beds at holes 8 to 10, Sewell.

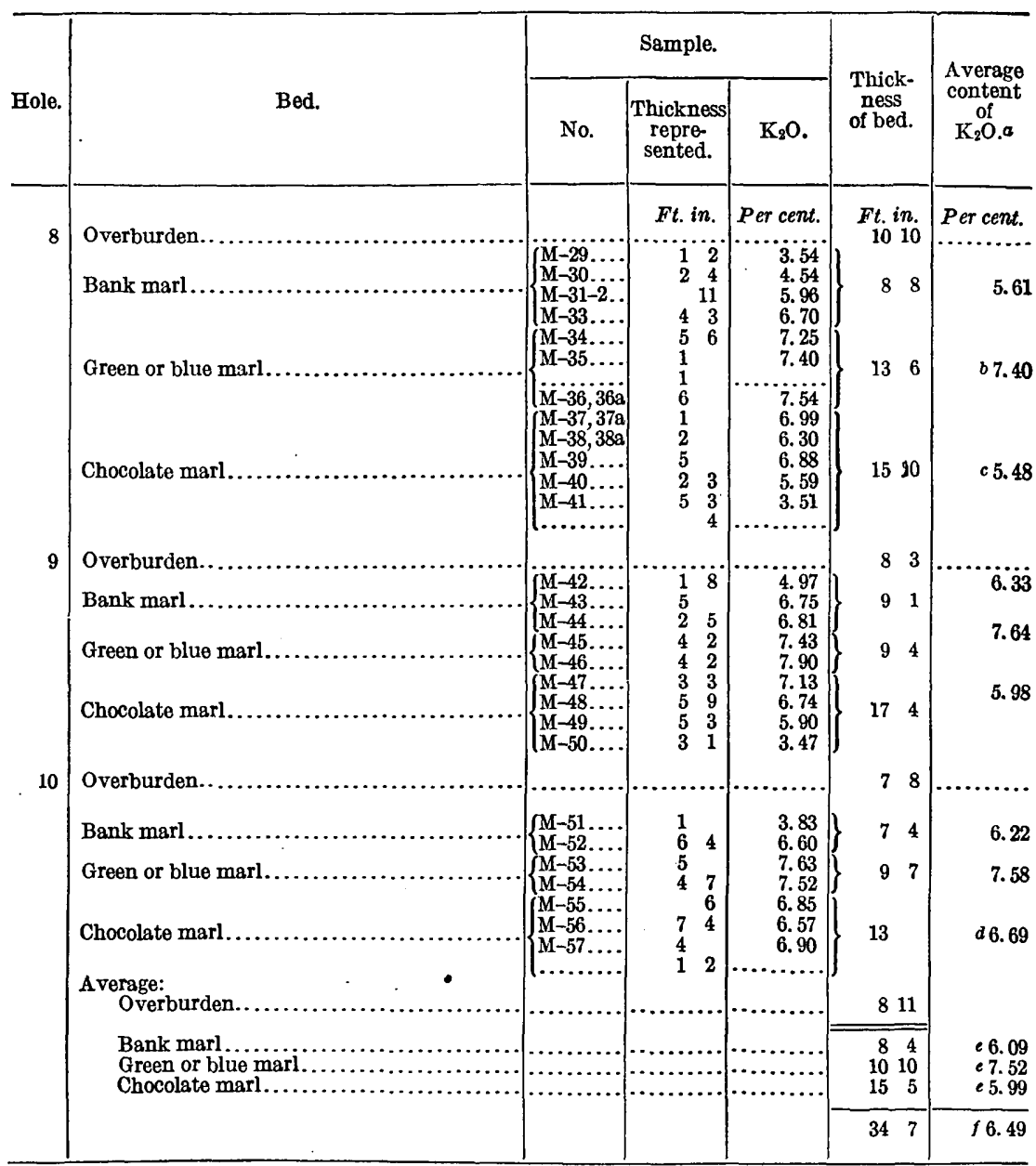

a Average for bed weighted according to the thicknesses represented by the respective samples. $b$ A verage for 12 feet 6 inches.

c Average for 15 feet 6 inches.

d Average for 11 feet 10 inches.

e Average for bed in 2.5-acre tract weighted according to thicknesses at the respective holes.

$f$ Average of entire thickness of marl in 2.5-acre tract. 
BORINGS OF WEST JERSEY MARL \& TRANSPORTATION CO.

Record of borings of West Jersey Marl \& Transportation Co., near Sewell.

\begin{tabular}{|c|c|c|c|c|c|c|c|}
\hline Locality.a & $\begin{array}{c}\text { Over- } \\
\text { burden. }\end{array}$ & $\begin{array}{l}\text { Bank } \\
\text { marl. }\end{array}$ & $\begin{array}{l}\text { Green } \\
\text { marl. }\end{array}$ & Locality.a & $\begin{array}{c}\text { Over- } \\
\text { burden. }\end{array}$ & $\begin{array}{l}\text { Bank } \\
\text { marl. }\end{array}$ & $\begin{array}{l}\text { Green } \\
\text { marl. }\end{array}$ \\
\hline 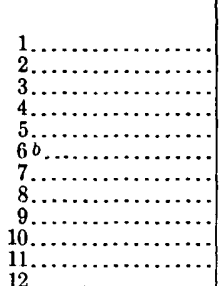 & $\begin{array}{cc}\text { Ft. } & \text { in. } \\
14 & 0 \\
18 & \\
21 & \\
18 & \\
12 & \\
21 & \\
15 & \\
21 & \\
12 & 6 \\
16 & \\
10 & \\
16 & \end{array}$ & $\begin{array}{ccc}\text { Ft. } & \text { in. } \\
12 & 6 \\
9 & \\
0 & \\
13 & \\
12 & \\
13 & \cdots \\
10 & \\
9 & 6 \\
13 & 6 \\
11 & \\
12 & \end{array}$ & $\begin{array}{c}\text { Ft. in. } \\
8 \\
7 \\
7 \\
7 \\
6 \\
\ldots 7 \\
7 \\
7 \\
7 \\
7 \\
7\end{array}$ & 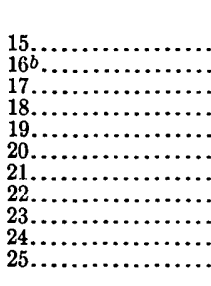 & $\begin{array}{c}\text { Ft. in. } \\
12 \\
22 \\
6 \\
19 \\
19 \\
6 \\
9 \\
8 \\
5 \\
5 \\
16\end{array}$ & $\begin{array}{c}\text { Ft. } \\
12 \\
\ldots \\
0 \\
14 \\
15 \\
11 \\
12 \\
4 \\
5 \\
5 \\
14\end{array}$ & \begin{tabular}{c} 
Ft. ${ }^{\text {in. }}$ \\
7 \\
\hdashline 6 \\
7 \\
7 \\
7 \\
7 \\
7 \\
7 \\
7 \\
7
\end{tabular} \\
\hline $13 \ldots \ldots \ldots \ldots \ldots \ldots \ldots \ldots \ldots \ldots \ldots \ldots$ & 13 & 11 & $\begin{array}{l}7 \\
7\end{array}$ & Average...... & 1310 & c 101 & c $6 \quad 11$ \\
\hline
\end{tabular}

These holes all stopped at or above the chocolate marl, which, because of its astringent qualities, was not considered desirable for agricultural use. The analyses of the chocolate marl at holes 8 to 10 show that it contains less potash than either the bank marl or the green marl but probably enough for commercial recovery by any process operative for the other two beds.

The average thickness of the overburden in the borings made by the company is nearly 2 feet greater than that for the 2.5 -acre tract represented by holes 8 to 10 , and that of the bank marl 1 foot 9 inches greater, but that for the green marl is nearly 4 feet less.

\section{SEWELL MARL PIT.}

The large pit belonging to the West Jersey Marl \& Transportation Co. is shown in figure 4 and as locality 36 on Plate I. Much of the pit is now overgrown and more or less slumped, but marl has been dug at the northwest corner (see Pl. VIII, $B$ ), where the following section is exposed and available for sampling.

Section of pit of West Jersey Marl \& Transportation Co., near Sewell (locality 96).

[R. K. Bailey, analyst.]

\begin{tabular}{|c|c|c|c|c|}
\hline . & $\begin{array}{l}\text { Thick- } \\
\text { ness. }\end{array}$ & Depth. & $\begin{array}{c}\text { Field } \\
\text { No. of } \\
\text { sample. }\end{array}$ & $\mathrm{K}_{8} \mathrm{O}$ \\
\hline 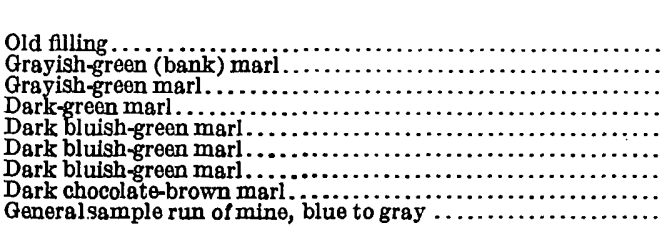 & \begin{tabular}{rr|}
$F t$. & in \\
5 & 9 \\
1 & \\
4 & 9 \\
1 & 6 \\
1 & \\
1 & 6 \\
1 & 6
\end{tabular} & $\begin{array}{rr}\text { Ft. } & \text { in } \\
5 & 9 \\
6 & 9 \\
11 & 6 \\
13 & \\
14 & \\
14 & 6 \\
15 & 6 \\
16 & \end{array}$ & $\begin{array}{r}\mathrm{M}-59 \\
\mathrm{M}-61 \\
\ddot{M}-60 \\
\underset{M}{\mathrm{M}}-62 \\
\mathrm{M}-63 \\
\cdots\end{array}$ & 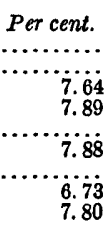 \\
\hline
\end{tabular}


The samples were collected as typical of the freshly dug material of the respective kinds. The analyses run higher than the average of the analyses of samples of similar beds from holes 8 to 10, though they are matched by analyses of individual samples from those holes. Probably all the marl now dug in this pit corresponds with the green marl at holes 8 to 10 . None of the stiff, clayey olivegreen marl found at those holes appears in the sampled part of the pit.

The overburden at older exposures on the east and southeast sides of the pit is 12 to 15 feet thick and includes a little Kirkwood sand beneath the Pleistocene sand and gravel. Locally a thin bed of sand and gravel cemented with oxide of iron (ironstone) occurs beneath the Pleistocene. Westward from the pit the overburden increases to 10 or 15 feet.

\section{WELL DATA.}

Several wells in the vicinity of Sewell give further data on the thickness of the marl and the amount and character of the overburden. They also indicate water-bearing beds, which might be of use to companies interested in developing the marl. The writer is indebted to M. W. Twitchell for the following record of the well of F. J. Anspach.

Record of well of F. J. Anspach, near Sewell (locality s7).

[On Chews Hill, east of the Mantua road. Elevation, 82 feet; depth, 432 feet.]

\begin{tabular}{|c|c|c|c|}
\hline & $\begin{array}{c}\text { Thick- } \\
\text { ness. }\end{array}$ & Depth. & Formation. \\
\hline 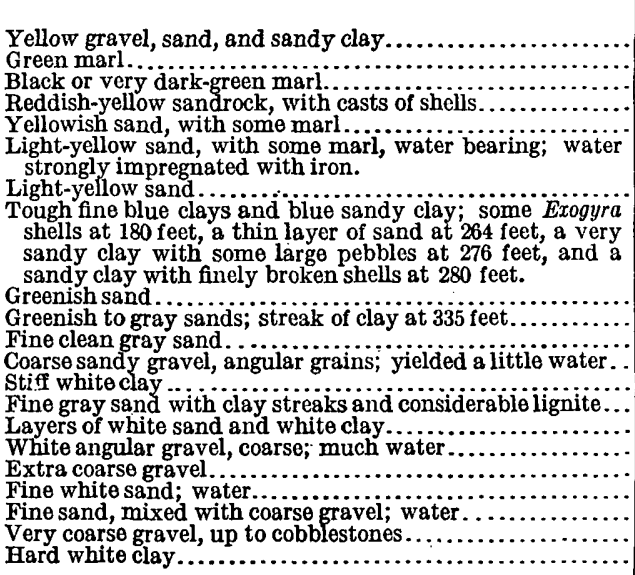 & $\begin{array}{r}\text { Feet. } \\
17 \\
7 \\
6 \\
13 \\
13 \\
16 \\
\\
32 \\
180 \\
\\
\\
\\
20 \\
31 \\
7 \\
9 \\
1 \\
23 \\
6 \\
14 \\
10 \\
3 \\
7 \\
5 \\
12\end{array}$ & $\begin{array}{l}304 \\
335 \\
342 \\
351 \\
352 \\
375 \\
381 \\
395 \\
405 \\
408 \\
415 \\
420 \\
432+\end{array}$ & $\left\{\begin{array}{l}\text { Pleistocene. } \\
\text { H ornerst ow n and } \\
\text { Navesink. } \\
\text { Mount Laurel and } \\
\text { Wenonah. } \\
\text { Marshalltown, English } \\
\text { town, Woodbury, } \\
\text { Merchantville. }\end{array}\right.$ \\
\hline
\end{tabular}


The water at 405 to 420 feet is utilized and is reported as pure, soft, and satisfactory in every respect. On pumping 40 gallons a minute the water stands at 77 feet below the surface.

The record shows 39 feet of the combined Hornerstown and Navesink marls beneath an overburden of 17 feet of gravel, sand, and clay.

Record of well of J. L. North, at Sewell (locality 38).

[A bout 0.21 mile N. $76^{\circ}$ E. of railroad station, in angle formed by two streets. Elevation, about 82 feet; depth, 336 feet. J. L. North, informant.]

\begin{tabular}{|c|c|c|c|}
\hline & $\begin{array}{l}\text { Thick- } \\
\text { ness. }\end{array}$ & Depth. & Formation. \\
\hline 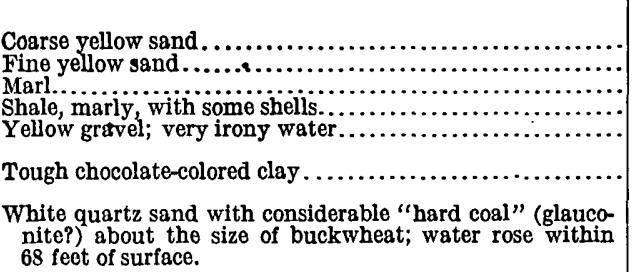 & $\begin{array}{r}\text { Feet. } \\
10 \\
30 \\
38 \\
20 \\
23 \\
200 \\
15\end{array}$ & $\begin{array}{r}\text { Feet. } \\
10 \\
40 \\
78 \\
98 \\
121 \\
321 \\
336\end{array}$ & $\begin{array}{l}\text { Pleistocene. } \\
\text { Kirkwood (?). } \\
\text { Horners to w and } \\
\text { Navesink. } \\
\text { Mount Laurel and } \\
\text { Wenonah. } \\
\text { Marshalltown to Mer- } \\
\text { chantville. } \\
\text { Magothy (?). }\end{array}$ \\
\hline
\end{tabular}

The overburden at this well is 40 feet thick, and the marl apparently 58 feet thick.

A well sunk for George B. Hurff at locality 39, near the North well, shows a similar record.

The well of David T. Locke at locality 40, in the same general vicinity, shows a somewhat different record.

Record of well of David T. Locke, at Sewell (locality 40).

[J. L. North, driller and informant.]

\begin{tabular}{|c|c|c|c|}
\hline . & $\begin{array}{c}\text { Thick- } \\
\text { ness. }\end{array}$ & Depth. & Formation. \\
\hline 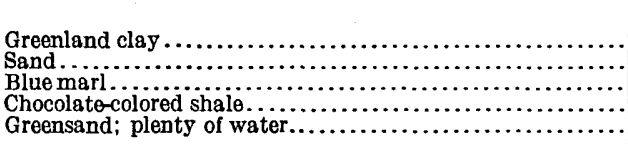 & $\begin{array}{r}\text { Feet. } \\
25 \\
10 \\
25 \\
11 \\
14\end{array}$ & $\begin{array}{r}\text { Feet. } \\
25 \\
35 \\
60 \\
71 \\
85\end{array}$ & $\begin{array}{l}\text { Pleistocene (?). } \\
\text { Kirkwood (?). } \\
\text { Hor ners to w and } \\
\text { Navesink (?). } \\
\text { Mount Laurel (?). }\end{array}$ \\
\hline
\end{tabular}

The "greenland clay" is probably reworked glauconitic material. The well may stop in the lower Navesink but probably stops in the top of the Mount Laurel. With these interpretations there would be 35 feet of overburden and nearly 50 feet of marl. If this location is correct the little knoll north of the well should be included in the greensand belt instead of with the pre-Navesink formations as mapped. 
A test well sunk near Sewell for the town of Woodbury gives a record interpreted by Twitchell as follows:

Record of well for town of Woodbury, near Sewell (locality 41).

[ $A$ bout three-fourths of a mile northeast of Sewell along strike of formations. Elevation, 13 feet (?); depth, 283 feet. Artesian Well Drilling Co., driller.]

\begin{tabular}{|c|c|c|c|}
\hline & $\begin{array}{l}\text { Thick- } \\
\text { ness. }\end{array}$ & Depth. & Formation. \\
\hline $\begin{array}{l}\text { Meadow mud............ } \\
\text { Sandy mud................ }\end{array}$ & $\begin{array}{l}\text { Feet }_{12} \\
\quad 63\end{array}$ & $\begin{array}{r}F_{\text {cet }} . \\
\quad 12 \\
75\end{array}$ & $\begin{array}{l}\text { Recent. } \\
\text { H ornerst own and }\end{array}$ \\
\hline Fine sand.............. & 7 & 82 & Laurel and \\
\hline Sticky clay... & 153 & 235 & Marshalltown to Mer- \\
\hline $\begin{array}{l}\text { Medium sand........ } \\
\text { Clay................ }\end{array}$ & 48 & 283 & $\begin{array}{l}\text { cnantville. } \\
\text { Magothy and Raritan. }\end{array}$ \\
\hline
\end{tabular}

The town of Woodbury now has in this vicinity a group of eight 10-inch wells, according to J. L. North, who has kindly indicated their positions as shown on the map (Pl. I). As above interpreted the thickness of the overburden is not excessive, but the thickness of the marl is unusual.

The records and locations of the three following wells were furnished by J. L. North.

Record of well of John Schmidt, near Salina (locality 41a).

[Elevation, about 60 feet.]

\begin{tabular}{|c|c|c|c|}
\hline & $\begin{array}{c}\text { Thick- } \\
\text { ness. }\end{array}$ & Depth. & Formation. \\
\hline 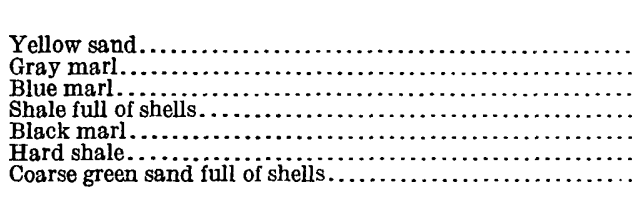 & $\begin{array}{r}\text { Feet. } \\
14 \\
10 \\
40 \\
30 \\
7 \\
2 \\
14\end{array}$ & $\begin{array}{r}\text { Feet. } \\
14 \\
24 \\
64 \\
94 \\
101 \\
103 \\
117\end{array}$ & $\left\{\begin{array}{l}\mathrm{K} \text { irk wood (?) and } \\
\text { Vincentown. } \\
\text { Horners town and } \\
\text { Navesink (?). } \\
\text { Mount Laurel and } \\
\text { Wenonah (?). }\end{array}\right.$ \\
\hline
\end{tabular}

From the location of the well there is little doubt that the gray marl and perhaps much of the overlying sand is Vincentown. Possibly part of the "blue marl" may be a more glauconitic phase of the Vincentown, for the marl here seems unduly thick. The base of the Navesink is not distinguished but may be represented by the "hard shale." The "coarse green sand" is probably the water-bearing Mount Laurel and Wenonah sands, which are locally more or less glauconitic. 
Record of well of Thomas Burroughs, near Hurffille (locality 41b).

[Elevation, about 90 feet.]

\begin{tabular}{|c|c|c|c|}
\hline & $\begin{array}{c}\text { Thick- } \\
\text { ness. }\end{array}$ & Depth. & Formation. \\
\hline 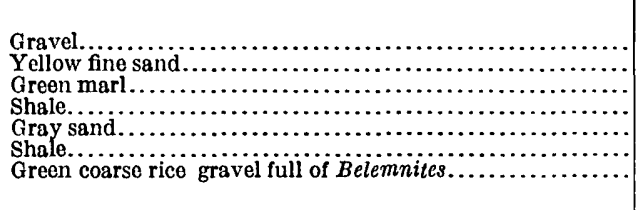 & $\begin{array}{r}\text { Feet. } \\
10 \\
50 \\
60 \\
4 \\
6 \\
2 \\
15\end{array}$ & $\begin{array}{r}\text { Feet. } \\
10 \\
.60 \\
120 \\
124 \\
130 \\
132 \\
147\end{array}$ & $\begin{array}{l}\text { Pleistocene. } \\
\text { Kirkwood. } \\
\text { V in cent o w n(?) to } \\
\text { Navesink. } \\
\text { Mount Laurel and Wo- } \\
\text { nonah. }\end{array}$ \\
\hline
\end{tabular}

This record corresponds fairly well with the preceding. The Vincentown is not distinguished but is probably present.

Record of well of Felix Behl, at Fairview (locality 41c).

[Elevation, about 125 feet.]

\begin{tabular}{|c|c|c|c|c|}
\hline & $\begin{array}{l}\text { Thick- } \\
\text { ness. }\end{array}$ & Depth. & Formation. & \\
\hline 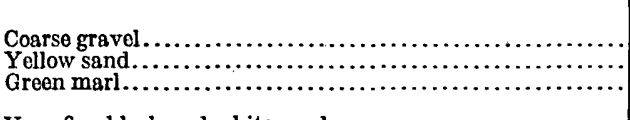 & $\begin{array}{r}- \text { Feet. } \\
28 \\
35 \\
30\end{array}$ & $\begin{array}{r}\text { Feet. } \\
28 \\
63 \\
93\end{array}$ & $\begin{array}{l}\text { Plelstocene. } \\
\text { Kirkwood (?). } \\
\text { Hornerstown } \\
\text { Navesink. }\end{array}$ & and \\
\hline 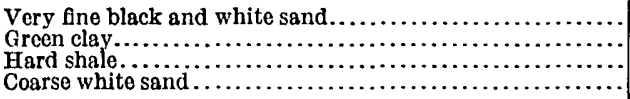 & $\begin{array}{r}40 \\
23 \\
5 \\
14\end{array}$ & $\begin{array}{l}133 \\
156 \\
161 \\
175\end{array}$ & $\begin{array}{l}\text { Mount Laurel } \\
\text { Wenonah (?) }\end{array}$ & and \\
\hline
\end{tabular}

The formations are not clearly distinguishable from these records, but they indicate the continuity of the marl in considerable thickness, though the overburden is heavy.

Two wells at Pitman show the amount and character of the overburden and the thickness of the marl in that district.

Record of well in camp-meeting grounds at Pitman (locality 42).a

[A bout one-third of a mile southwest of railroad station, on nearly the lowest ground in the area, at west edge of grove. Elevation, 110 feet. Haines Bros., drillers.]

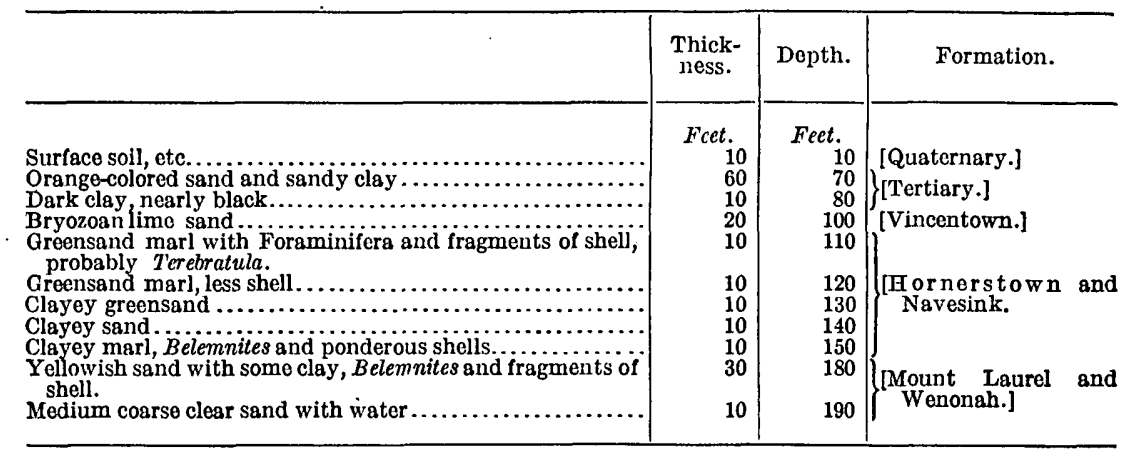

a New Jersey Geol. Survey Ann. Rept. for 1896, p. 128, 1897. 
A well sunk for the town of Pitman on the east side of the railroad at locality 43 , not far from the well just described, was drilled to a depth of 507 feet. For the first 190 feet its record was practically identical with the other. ${ }^{16}$

A third well drilled in the same general vicinity, for R. H. Corney, started at an elevation of 130 feet and penetrated bryozoan lime sand between depths of 115 and 125 feet. Greensand was found between depths of 125 and 160 feet, and coarse water-bearing gravels from 160 to 180 feet. $^{17}$

These wells show that at Pitman limesand 10 to 20 feet thick and greensand 35 to 50 feet thick lie beneath Tertiary and Quaternary deposits from 70 to 115 feet or more thick.

OTHER DATA.

The Kern pits, which lie on the east side of Chestnut Branch, about 1.5 miles above Sewell (locality 44), were visited in 1917 by Dr. Kümmel, from whose notes the following data were obtained. There is a very large opening, and the floor is overgrown with trees 6 inches or more in diameter. The bank is very high. Marl probably rises about 5 feet above the floor. Where the pit is most swampy the marl has 15 to 25 feet of overburden consisting of about 10 feet of yellow gravel, underlain by Kirkwood sand.

On the map of 1866 is shown a railroad running to these pits and marked "W. J. R. R." In the annual report of the State geologist for 1886, page 178, it is stated that "southeast of Barnsboro in Gloucester County, on the south branch of Mantua Creek, are important marl pits, one of which is worked by the West Jersey Marl Co. in a layer containing 12 feet of green marl."

Near the lower bridge over Bees Branch (locality 45) a pit owned by Howard Davis was in operation in September, 1917, when visited by Dr. Kümmel, who observed the following section:

Section of marl pit of Howard Davis, on Bees Branch near Sewell (locality 45).

[Elevation of surface, about 60 feet.]

Feet.

A. Yellow sand and gravel

5-7

B. Brown marly sand with obscure casts of Terebratula harlani stained reddish brown locally

C. Reddish-brown to black marl with dark-green more or less mottled marl, purer at base.......................

D. Green marl; locally streaks with discontinuous irregular lines of light chocolate-colored clay, only a minor feature. At 3 inches from top iron-incrusted seam. Basal 2 feet is blacker than upper part 
In digging layers $\mathrm{A}, \mathrm{B}$, and $\mathrm{C}$ are thrown away. The base of layer $\mathrm{D}$ is the level of the uneven floor. Marl is dug in layer E, 8 feet below this level, but at the time when these observations were made only layer $\mathrm{D}$ was being taken. Near by was a worked out pit in layer E full of water. When visited in November, 1918, by Dr. Kümmel and the writer the Davis pit was inactive and badly slumped.

On the William Wenzell place, just west of Sewell, 10 feet of greensand is overlain by 8 to 10 feet of clay and gravel. A sample of the greensand collected by W. C. Phalen was analyzed in the laboratories of the United States Geological Survey and found to contain 7.09 per cent of potash. ${ }^{18}$

IIME SAND.

At locality 46, south of the road from Sewell to Barnsboro and west of the creek, there is an exposure of 3 to 4 feet of lime sand. At locality 47, near Hurffville, some old pits in the Vincentown sand were visited in 1915 by Dr. Kümmel, who found them slumped and overgrown. In a circular published in 1903 these pits were cited as a good locality, and in the annual report of the State geologist for 1886, page 178, a section measured at these pits showed 9 feet of lime sand and 13 feet of greensand marl. These two localities furnish the exposures of the lime sand nearest to Sewell. It probably underlies the surface from half a mile to a mile south of the West Jersey Marl \& Transportation Co.'s pit, but the overburden is doubtless thicker than 15 feet. No data regarding the quality of this lime sand are available.

\section{ESTIMATES OF TONNAGE AND VALUE.}

From the data given on page 50, the average thickness of the marl in the 2.5-acre tract near Sewell may be taken as 34 feet and its average potash content as 6.50 per cent. On the assumption, as in previous estimates, that the weight of the greensand, 28 per cent being allowed for voids, is 133 pounds per cubic foot, an acre in the specified tract would contain $\frac{43,560 \times 34 \times 133 \times 0.065}{2,000}=6,400$ tons of potash $\left(\mathrm{K}_{2} \mathrm{O}\right)$, and the 2.5 acres would contain 16,000 tons. With an 80 per cent recovery and a price of $\$ 2.50$ per unit of 20 pounds (March, 1920), the potash in a ton of greensand would be worth $\$ 13$ and that in an acre of ground would be worth $\$ 1,280,000$. At the more probable price of $\$ 1.50$ per unit the same quantities of potash would be worth $\$ 7.80$ and $\$ 768,000$, respectively. The values given for the potash are purely hypothetical, as they are dependent

${ }^{18}$ Ashley, G. H., Notes on the greensand deposits of the eastern United States: U.S. Geol. Survey Bull. 660 , pp. 40, 47, 1918. $88625^{\circ}-22 \longrightarrow 5$ 
upon successful extraction of the potash by processes not yet commercially demonstrated.

As previously explained, the marl beds are beveled off by erosion along the north boundary of the belt, but along the southeast border their thickness is probably as much as 50 feet. The well records and other data indicate that greensand marl is present, except where locally eroded, throughout the portion of the belt included in the Sewell district and that it may be expected to maintain a fairly uniform thickness along the strike.

\section{DTIIIZATION OF THE DEPOSITS.}

The thickness of the overburden in the 2.5-acre tract averages about 9 feet. At the borings made by the West Jersey Marl \& Transportation Co. the average thickness of the overburden was about 14 feet. Thus in the vicinity of Sewell there appear to be considerable areas in which the overburden is less than 15 feet.

There is no water transportation within suitable distance from Sewell, but excellent railroad service is available. Possibly Mantua Creek could be utilized below West Landing for the marl beds within a mile south of Mantua.

Marl of suitable quality is present in sufficient quantity near Sewell to justify large-scale operations and can be worked in open pits by steam shovels or other types of excavators. Water is not so near the surface in Sewell as in some of the other localities tested but would be encountered in handling the green and chocolatecolored beds.

The analyses show that the green marl contains about 1.5 per cent more potash than the bank or chocolate marls but that all the beds may probably be profitably worked by any extraction process applicable to the green marl.

\section{BLACKWOOD.}

Years ago the marl was dug and was well exposed near Blackwood. According to Cook, ${ }^{19}$

At Blackwood town the whole bed ("Middle marl") can be seen by going upstream from Good Intent toward the southeast. David C. Marshall's pits *** are good examples of the bed, having on top 6 to 12 feet red or gray marl, 7 feet pale-green marl, and from 18 to 20 feet of green marl, and then chocolate marl.

These pits or pits in their vicinity were visited in 1917 by Dr. Kümmel, who observed the following section:

Section of marl beds in pits near Blackwood (locality 48).

Feet.

Yellow sand and gravel............................. 13-14

Brownish and clayey sand; weathered marl (?).............. 1

Marl about half quartz and half glauconite................. 15

Bottom of banks.

19 Cook, G. H., Geology of New Jersey, p. 272, 1868. 
The pits in this vicinity are now largely filled in and swampy. In 1918 the writer, with Dr. Kümmel, visited a locality about a quarter of a mile farther up the creek. Here, beneath 15 to 20 feet of Pleistocene sand and gravel, about 4 or 5 feet of lime sand overlies the greensand marl, about 5 feet above the level of the swamp. The shell bed is absent. According to data at the office of the State geologist good exposures of black greensand marl, representing 10 feet of the Hornerstown, occur at locality 49, about 1 mile northwest of Good Intent, beside the road.

The marl is exposed in the fields in the valley between Blackwood and Blenheim, close to the railroad. This might be a suitable place for commercial development, but the full thickness of the marl is probably not present. That the marl is present in considerable thickness at Blackwood is shown by the record of two wells sunk about 2,000 feet apart for F. Pine and H. Runkel. The localities of these wells are not given, but their records are very similar, except that the Pine well starts at a somewhat lower elevation and is a little deeper. ${ }^{20}$ Its record, as furnished by M. W. Twitchell, is as follows:

Record of well of F. Pine at Blackwood.

[Elevation, 50 feet. F. E. McCann, driller.]

\begin{tabular}{|c|c|c|c|}
\hline & $\begin{array}{c}\text { Thick- } \\
\text { ness. }\end{array}$ & Depth. & Formation. \\
\hline 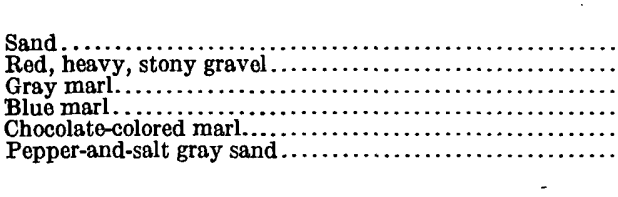 & $\begin{array}{r}\text { Feet. } \\
6 \\
10 \\
7 \\
5 \\
32 \\
10\end{array}$ & $\begin{array}{r}\text { Feet. } \\
6 \\
16 \\
23 \\
28 \\
60 \\
70\end{array}$ & $\begin{array}{l}\text { Pleistocene. } \\
\text { Hornerstown and } \\
\text { Navesink. } \\
\text { Mount Laurel and } \\
\text { Wenonah. }\end{array}$ \\
\hline
\end{tabular}

A well sunk at Greenloch, about seven-eighths of a mile southeast of the Camden County asylum, gives the following record:

Record of well of S. R. Bateman (?), near Greenloch (locality 50).

[Elevation, 45 feet. J. L. North, driller.]

\begin{tabular}{|c|c|c|c|}
\hline & $\begin{array}{c}\text { Thick- } \\
\text { ness. }\end{array}$ & Depth. & Formation. \\
\hline 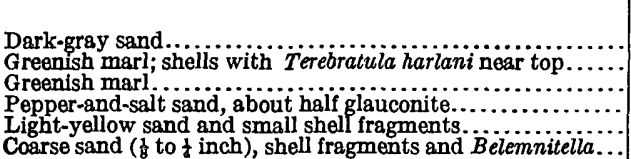 & $\begin{array}{r}\text { Feet. } \\
22 \\
28 \\
30 \\
1 \\
23 \\
4\end{array}$ & $\begin{array}{r}\text { Feet. } \\
22 \\
50 \\
80 \\
81 \\
104 \\
108\end{array}$ & $\begin{array}{l}\text { Vincentown. (?) } \\
\text { Hornerstown and } \\
\text { Navesink. } \\
\text { Mount Laurel. }\end{array}$ \\
\hline
\end{tabular}

The Pine well, which does not afford a complete section, shows 44 feet of marl. The Bateman well, which apparently gives a com-

${ }^{20}$ New Jersey Geol. Survey Ann. Rept. for 1901, p. 88, 1902. 
plete section, though the lower shell bed seems to be not well developed, shows 59 feet of marl.

No recent data are available regarding the quality of the marl at Blackwood, but it is probable that other conditions being favorable its quality would justify commercial development.

The lime sand occurs along the stream valleys above Blackwood, as shown on the map. Dr. Kümmel notes a good exposure of it at locality 51 , by the road at the pumping station, about half a mile northwest of Greenloch, where it consists of a mass of Bryozoa and other fossils and is covered by a reddish clayey residual soil.

A well at Asyla, half a mile northwest of Greenloch, shows 35 feet of greensand, including the Terebratula bed, beneath 5 feet of surface soil that contains occasional fragments of lime-sand rock. ${ }^{21}$

SOMERDALE DISTRICT.

SELECTION OF SITES.

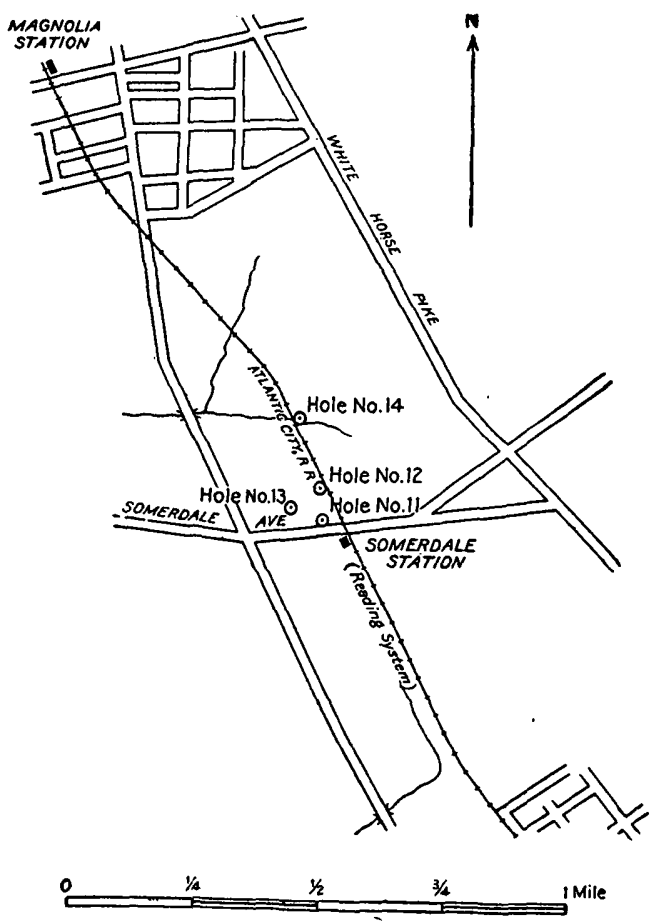

FIGURE 5.-Sketch map of part of the Somerdale district, showing the location of holes 11 to 14 .

In the vicinity of Somerdale, in Camden County, the greensand marl occupies a rather broad belt, as shown on the map (Pl. II), and the overburden is apparently not excessive. The Atlantic City Railroad (Reading system) and the Camden \& Atlantic Railroad (Pennsylvania system) provide excellent transportation facilities.

A drilling site was selected on the southeast edge of the belt, near Somerdale station, in a corn field belonging to Thomas McMichael, Laurel Springs post office.

\section{HOLES 11 TO 14.}

A 2.5-acre tract was again selected and holes 11,12 , and 13 were sunk as indicated in figure 5. A fourth hole, No. 14, was bored about a quarter of a mile northwest of the station, at the culvert on the east side of the track, to explore the so-called red marl, which was reported to be beneficial to crops. The records of these holes follow:

21 Woolman, Lewis, Report on artesian wells: New Jersey Geol. Survey Ann. Rept. for 1902, pp. 59-95, 71-72, 1903. 
Records of holes in Somerdale district.

Locality 52, hole 11 .

[Farm of Thomas McMichae], 50 feet north of Somerdale Avenue and 210 feet west of railroad at Somerdale station. Elevation of surface, about 85 feet. R. K. Bailey, analyst; S. J. Taylor, driller.]

\begin{tabular}{|c|c|c|c|c|c|}
\hline & $\begin{array}{l}\text { Thick- } \\
\text { ness. }\end{array}$ & Depth. & $\begin{array}{l}\text { Field } \\
\text { No. of } \\
\text { sample. }\end{array}$ & $\mathrm{K}_{2} \mathrm{O}$. & Formation. \\
\hline $\begin{array}{l}\text { Top soil, greenish-yellow clayey sand, becoming } \\
\text { more yellowish and containing scattered peb- } \\
\text { bles. }\end{array}$ & Ft. in. & Ft. in & & Per cent. & Quaternary. \\
\hline $\begin{array}{l}\text { Clay, sandy, greenish to grayish drab, with scat- } \\
\text { tered pebbles as large as } 1 \text { inch in diameter } \\
\text { and grains of weathered glauconite. Toward } \\
\text { base deeper color, larger proportion of glau- } \\
\text { conite, more numerous pebbles. }\end{array}$ & 15 & 29 & & & Do. \\
\hline $\begin{array}{l}\text { Glauconite beds with very stiff olive-colored clay } \\
\text { matrix and a few pebbles; red streaks of oxi- } \\
\text { dized material. }\end{array}$ & 3 & 3 & & 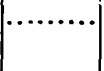 & Do. \\
\hline $\begin{array}{l}\text { Glauconite beds similar to above but with few if } \\
\text { any pebbles; red streaks die out at base. }\end{array}$ & 12 & 42 & $M-65$ & 6.94 & Hornerstown. \\
\hline $\begin{array}{l}\text { Glauconite bedssimilar to M- } 65 \text { but without the } \\
\text { weathered iron streaks. At base a pebble } 3 \\
\text { inches in diameter. }\end{array}$ & 110 & 6 & $M-66$ & 7.58 & Do. \\
\hline $\begin{array}{l}\text { Glauconite beds, olive-colored, clayey, less stiff } \\
\text { and with somewhat mealy texture. }\end{array}$ & 33 & $\begin{array}{ll}9 & 3\end{array}$ & $M-67$ & 7.52 & Do. \\
\hline Glauconite beds similar to $M-67 \ldots \ldots \ldots \ldots \ldots$ & 47 & 1310 & $\mathrm{M}-68$ & 7.58 & Do. \\
\hline $\begin{array}{l}\text { Glauconite beds, a little less clayey, brownish- } \\
\text { gray material mingled with olive-green, be- } \\
\text { comes more brownish at base. }\end{array}$ & 29 & 167 & $\mathrm{M}-69$ & 6.74 & Navesink. \\
\hline $\begin{array}{l}\text { Glauconite beds similar to above, discarded in } \\
\text { clearing casing after driving. }\end{array}$ & 1 & 177 & & & Do. \\
\hline $\begin{array}{l}\text { Glauconite beds, brownish drab with some in- } \\
\text { termingling of grayish-green and chocolate- } \\
\text { colored streaks, consistency less stiff. A few } \\
\text { scattered gravel grains. }\end{array}$ & 45 & 22 & $\mathrm{M}-70$ & 6.67 & Do, \\
\hline $\begin{array}{l}\text { Glauconite beds, lighter greenish drab, greenish } \\
\text { and chocolate-colored streaks, white films sur- } \\
\text { rounding some of glauconite grains. }\end{array}$ & 5 & 27 & M-71 & 6.60 & Do. \\
\hline $\begin{array}{l}\text { Glauconite beds similar to above but mingled } \\
\text { with overlying material in driving pipe and } \\
\text { discarded. }\end{array}$ & 16 & 286 & & & Do. \\
\hline $\begin{array}{l}\text { Glauconite beds, greenish drab, rice gravel and } \\
\text { quartz Sand sufficiently abundant to suggest } \\
\text { basalbed of formation. }\end{array}$ & 3 & 316 & $\mathrm{M}-72$ & 5.12 & Do. \\
\hline $\begin{array}{l}\text { Glauconite beds becoming more sandy with } \\
\text { lessclay; glauconiteand gravel in diminishing } \\
\text { proportion. }\end{array}$ & 53 & 369 & & & $\begin{array}{l}\text { Mount Laurel and } \\
\text { Wenonah. }\end{array}$ \\
\hline
\end{tabular}


Locality 53, hole 12 .

[Farm of Thomas McMichael, at Somerdale, 330 feet N. $22^{\circ} \mathrm{W}$. from hole 11. Elevation of surface, about 85 feet. R. K. Bailey, analyst; S. J. Taylor, driller.]

Top soil about 3 inches, then stiff olive-green glauconitic clay with rootlets worked by plow to depth of about

Glauconite beds, olivegreen, stiff, clayey, streaked with red iron-stained clay. Two pebbles noted at depths of 22 and 28 inches but rejected from sample, a few gravel grains included.

Glauconite beds, olive-green, stiff, clayey, with a few brownish streaks. A fow gravel grains and one pebble noted.

Glauconite beds, yellowish olive-colored, somewhat mealy texture, yellowish sandy streaks, fine yellow powdery clay at base.

Glauconite beds, light chocolate-brown with mingling of green in upper 4 inches.

Glauconite beds, drab to grayish green, firm, hard to drill, much clay but considerable percentage of black glauconite.

Glauconite beds, brownish to greenish drab, with irregular'streaks of brown and green, somewhat mealy texture, much black glauconite.

Glauconite beds like last but with some grains of quartz and a few gravel grains at base.

Glauconite beds similar to M-79.

Glauconite beds, sandy and hard to drill, a sort of hardpan; considerable quartz mixed with the glauconite; cementing clay chocolatebrown; becomes more sandy downward with abundant grains of rice gravel near base; no shells observed.

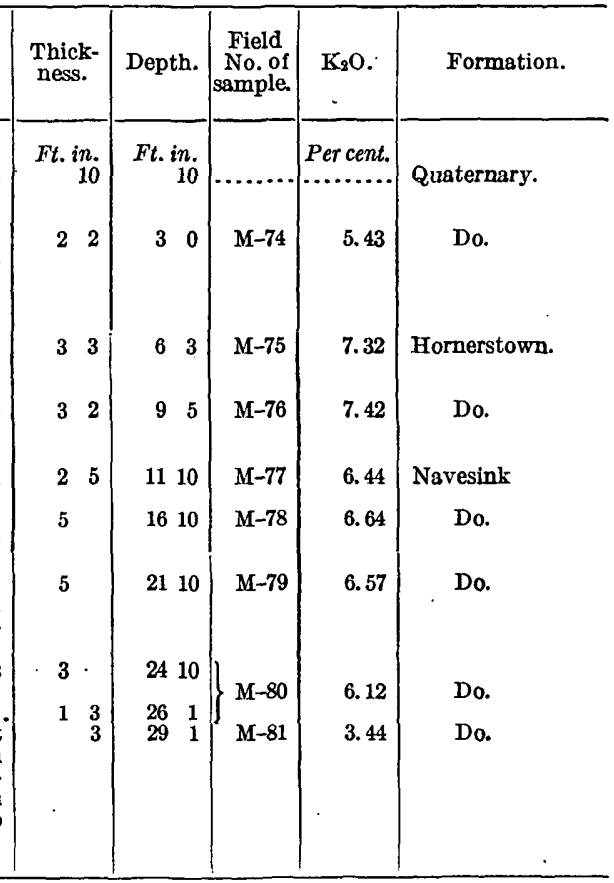


Locality 54, hole 13.

[Farm of Thomas McMichael, Somerdale, 330 feet S. $871^{\circ}$ E. from center of line between holes 11 and 12. Elevation of surface, about 89 feet. R. K. Bailey, analyst; S. J. Taylor, driller.]

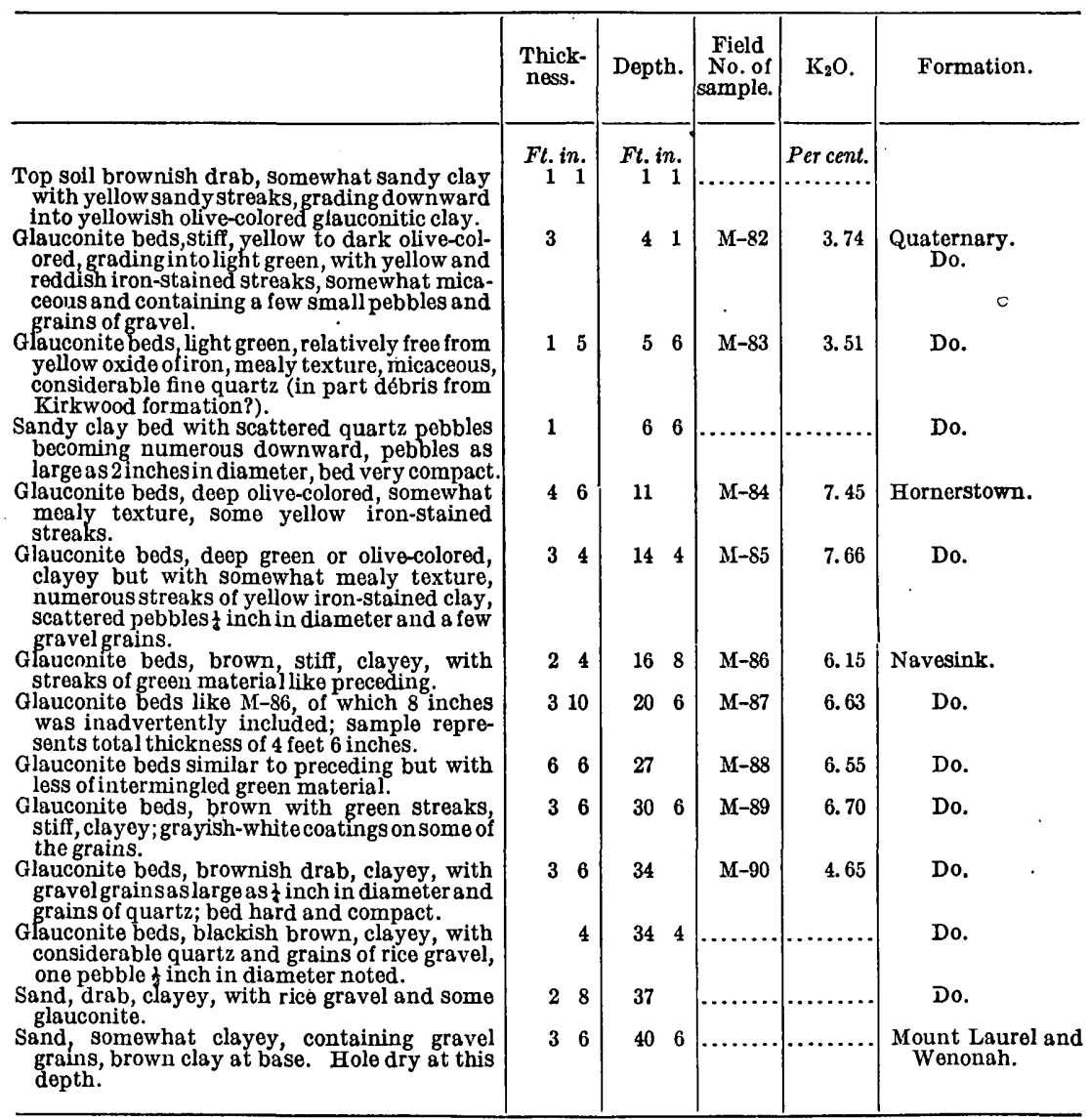

Locality 55, hole 14 .

[Farm of Thomas McMichael, Somerdale, at culvert about one-fourth of a mile northwest of Somerdale station, east of track and north of creek. R. K. Bailey, analyst; S. J. Taylor, driller.]

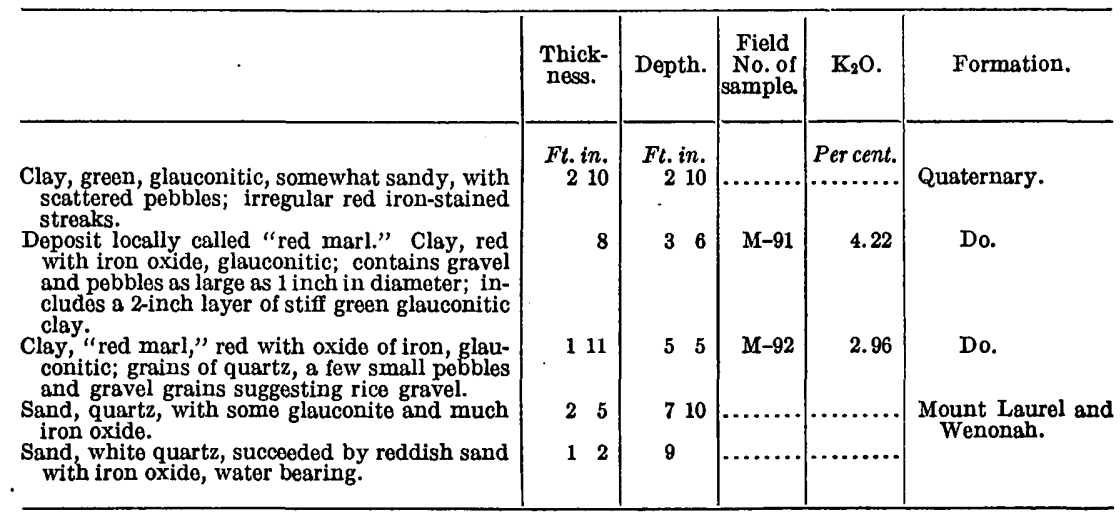


For comparison with other localities the data furnished by holes 11 to 13 are summarized below.

Thickness and quality of greensand beds at holes 11 to 13, Somerdale.

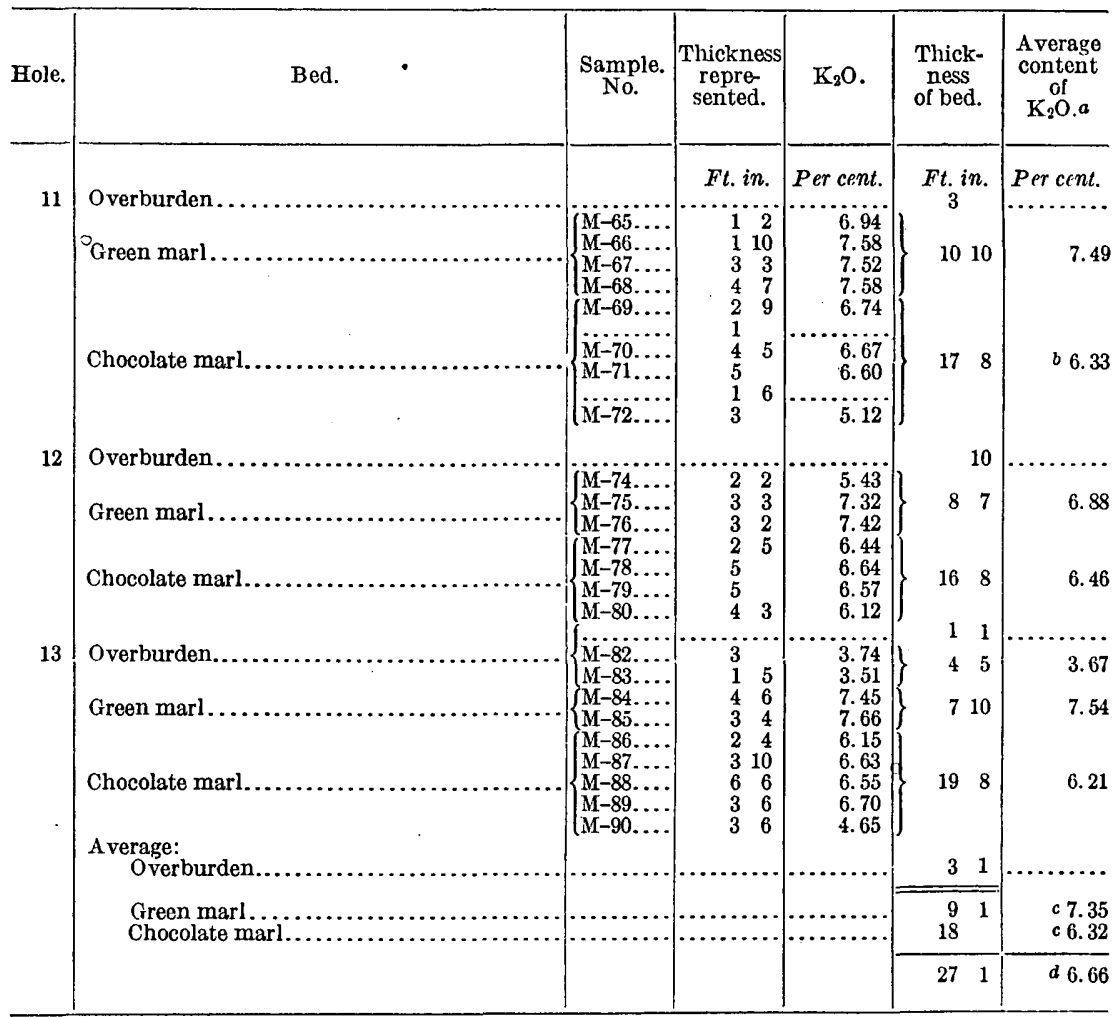

a Average for bed weighted according to the thicknesses represented by the respective samples.

$b$ Average for 15 feet 2 inches but assumed to be approximate for entire bed of 17 feet 8 inches.

$c$ A verage for the bed in 2.5-acre tract weighted according to its thickness at the respective holes.

$d$ Average of entire thickness of marl in the 2.5-acre tract.

As shown in the above table, the maximum thickness of the overburden in the 2.5 -acre tract is 5 feet 6 inches, and the average is 3 feet 5 inch. At hole 13 the overburden consists in part of reworked marl and carries significant amounts of potash, though perhaps not enough to be considered commercially.

The green marl in the same tract has a maximum thickness of 10 feet 10 inches, averages about 9 feet, and carries 7.54 per cent of potash $\left(\mathrm{K}_{2} \mathrm{O}\right)$. The chocolate marl has a maximum thickness of 19 feet 8 inches, averages 18 feet, and contains 6.21 per cent of potash. The entire marl bed averages 27 feet in thickness and carries 6.66 per cent of potash.

At hole 14 the so-called red marl consists of reworked glauconitic material, oxidized, and mingled with gravel but containing a maximum of 4.22 per cent of potash for the samples analyzed. The 
material appears to be a local deposit of Quaternary age which contains too little potash to be of commercial interest.

WELI DATA.

A number of wells sunk within a radius of 2 or 3 miles of Somerdale throw additional light on the thickness and character of the overburden and the thickness of the marl in the Somerdale district. At Magnolia a well drilled near the station ${ }^{22}$ showed 4 feet of overburden consisting of yellow clay and sand succeeded by 32 feet of "blue" marl underlain by water-bearing sands and other strata to the depth of 91 feet. A well drilled for Walter Hunt ${ }^{23}$ about threequarters of a mile northwest of Kirkwood station (locality 56 ?), shows 50 feet of greensand marl beneath 44 feet of yellow quicksand, and a second well, ${ }^{24}$ described as 1 mile south-southeast of the well just cited, shows 30 feet of "black mud" (greensand?) and 12 feet of green marl beneath 50 feet of yellow quicksand.

The well at the Stratford House, nearly midway between Kirkwood station and Stratford station and on nearly the highest ground, furnishes the following record: ${ }^{25}$

Record of well at Stratford House, near Kirkwood (locality 57).

[Elevation, 100 feet. Water rises within 51 feet of surface.]

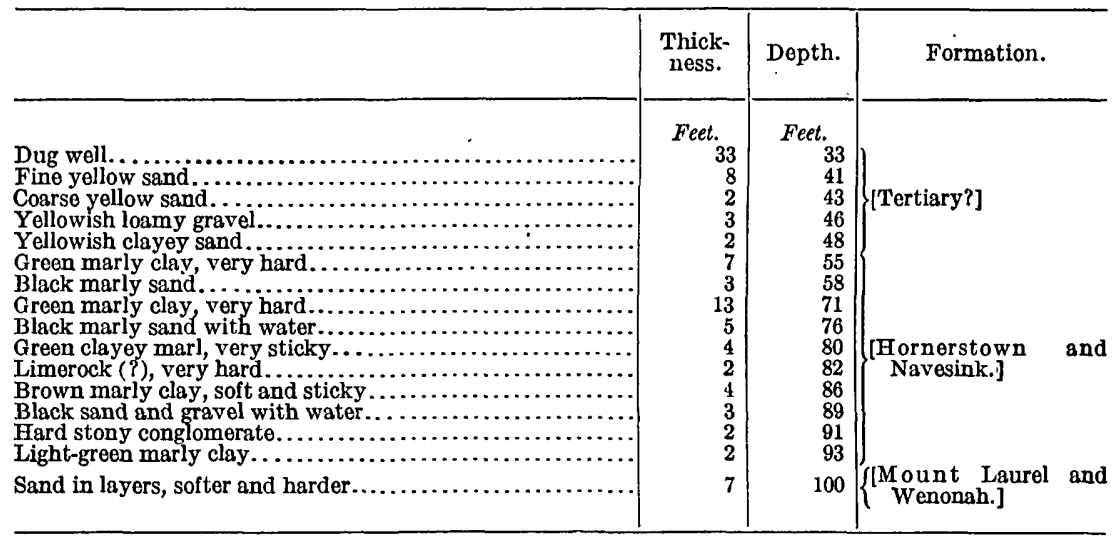

If the above record is properly interpreted there is 45 feet of marl beneath 48 feet of overburden.

At Laurel Springs a well drilled southwest of the railroad, near the millpond, for Joseph Eldridge ${ }^{26}$ shows the following record:

\footnotetext{
${ }^{22}$ New Jersey Geol. Survey Ann. Rept. for 1894, p. 197, 1895

${ }^{23}$ Idem for 1901, p. 86, 1902.

21 Idem, p. 87.

25 Idem for 1897, pp. 255-256, 1898.

26 Idem for 1901, p. 88, 1902.
} 
Record of well of Joseph Eldridge, near Laurel Springs (locality 58?).

[Elevation, 60 feet. F. E. McCann, driller.]

\begin{tabular}{|c|c|c|c|}
\hline & $\begin{array}{l}\text { Thick- } \\
\text { ness. }\end{array}$ & Depth. & Formation. \\
\hline 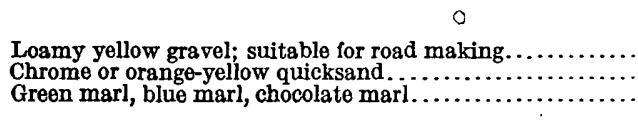 & $\begin{array}{r}\text { Feet. } \\
18 \\
22 \\
40\end{array}$ & $\begin{array}{r}\text { Feet. } \\
18 \\
40 \\
80\end{array}$ & $\begin{array}{l}\text { Quaternary. } \\
\text { Kirkwood(?) } \\
\text { Hornerstown and } \\
\text { Navesink. }\end{array}$ \\
\hline 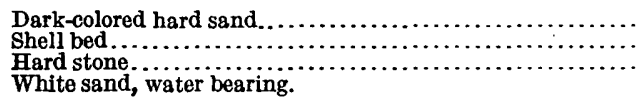 & $\begin{array}{r}15 \\
7 \\
1\end{array}$ & $\begin{array}{r}95 \\
102 \\
103\end{array}$ & $\left\{\begin{array}{l}\text { Mount Iaurel and } \\
\text { Wenonah. }\end{array}\right.$ \\
\hline
\end{tabular}

The position of the base of the Navesink is not clear from the above section, but there seems to be at least 40 feet of marl beneath 40 feet of overburden at this locality.

\section{OTHER DATA.}

From an old marl pit southwest of Laurel Springs, where the greensand was 10 to 12 feet thick and was overlain by 20 feet of overburden, W. C. Phalen collected a sample which was analyzed in the laboratory of the United States Geological Survey and found to contain 6.40 per cent of potash. ${ }^{27}$

A large marl pit at locality 59, on the west side of the railroad track, about 0.6 mile N. $20^{\circ}$ W. of Kirkwood station, was visited by Dr. Kümmel, who observed the following section at the north end of the pit near the railroad:

Section at marl pit about 0.6 mile N. $20^{\circ}$ W. of Kirkwood station (locality 59).

[Elevation, about 58 feet.]

\begin{tabular}{|c|c|c|}
\hline & $\begin{array}{l}\text { Thick- } \\
\text { ness. }\end{array}$ & $\begin{array}{l}\text { Forma- } \\
\text { tion. }\end{array}$ \\
\hline 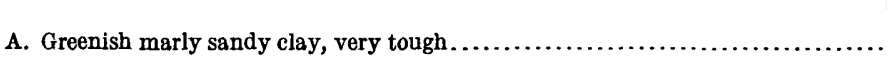 & Feet. & Ploisto- \\
\hline \multirow[t]{2}{*}{ 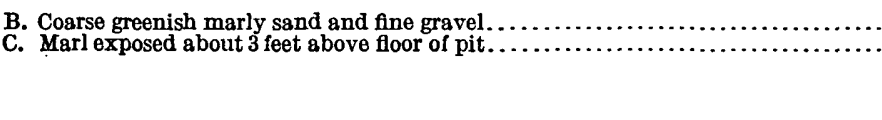 } & $3-4$ & $\begin{array}{c}\text { Do. } \\
\text { Horners- } \\
\text { town. }\end{array}$ \\
\hline & 10 & \\
\hline
\end{tabular}

There are no data about the former depth of the pit.

In 1918 a pit was opened in ground purchased by the Coplay Cement Co., of Coplay, Pa., at locality 60, about 0.3 mile due south of Osage station. A few carloads of greensand dug in this pit were shipped from Ashland. The pit was largely filled with water in

${ }^{27}$ Ashley, G. H., Notes on the greensand deposits of the eastern United States: U. S. Geol. Survey Bull. 660, pp. 40, 47, 1918. 
March, 1919. About 1.5 feet of greensand, corresponding with the green marl of holes 11 to 13, was exposed beneath an overburden of about 4 feet of sand, including a 6 -inch gravel bed just above the marl. A sample representing 1 foot of fresh material, analyzed in the laboratories of the Geological Survey, showed a total potash content of 7.17 per cent.

IIME SAND.

As shown on the map, the lime-sand phase of the Vincentown formation is exposed in branches of Timber Creek, near Laurel Springs. Beds of indurated lime sand full of Bryozoa may be seen at locality 61, in the bed of the brook, below the bridge $1 \frac{1}{2}$ miles west of Clementon. Some material taken for experimental purposes from this locality is reported to have contained as much as 80 per cent of carbonate of lime. Above Laurel Springs the lime sand occurs in close proximity to the railroad.

\section{ESTIMATES OF TONNAGE AND VALUE.}

As stated on page 64 , the average thickness of the marl bed in the 2.5-acre tract at Somerdale is 27 feet, and its average potash content is 6.66 per cent. On the assumption, as in previous estimates, of 28 per cent of voids and a weight of 133 pounds per cubic foot, the total potash in an acre of the 2.5-acre tract would amount approximately to $\frac{43,560 \times 27 \times 133 \times 0.0666}{2,000}=5,200$ tons. In the 2.5 -acre tract the total potash would be about 13,000 tons.

With an 80 per cent recovery and a price of $\$ 2.50$ per unit of 20 pounds (March, 1920) the potash in a ton of greensand would be worth $\$ 13.32$ and in an acre of the specified tract it would be worth $\$ 1,040,000$. At the more probable price of $\$ 1.50$ per unit the same quantities of potash would be worth $\$ 7.99$ and $\$ 624,000$ respectively. As in the previous estimates the values given for the potash are hypothetical, being dependent on the extraction of the potash by processes whose success has not yet been commercially demonstrated.

\section{UTILIZATION OF THE DEPOSITS.}

The 2.5-acre tract at Somerdale station is part of a larger area of suitable size and of sufficient potash content to justify commercial exploitation. No water transportation is available, but the district is served by two railroads and lies only 9 or 10 miles from Delaware River at Camden.

At holes 11 to 13 the water level was not reached at a depth of 40 feet 6 inches, and the marl was dryer than at any of the other holes 
bored. Absence of water would doubtless be an advantage in handling and shipping.

Northwestward from these holes the thickness of the marl may be expected to diminish to zero along the general northwest boundary of the belt indicated on the map (Pl. II). Along the southeast boundary, as shown by the well records cited, a thickness of 40 to 45 feet may be expected, but the overburden also is probably thicker.

\section{WINSLOW.}

A well at Winslow, near Hammonton, in Camden County, shows the increase in depth of the marl beds in the direction of the dip. In a distance of about 13 miles the top (?) of the Hornerstown marl has descended about 300 feet. This well was sunk about 1853 and is thought by Twitchell to be the first deep well in New Jersey. Its record has been repeated in somewhat varying form in reports of the New Jersey Survey from 1868 (Cook) to 1890. Its record, as worked out by Knapp, ${ }^{28}$ follows:

Record of well at Winslow.

\begin{tabular}{|c|c|c|}
\hline & $\begin{array}{c}\text { Thick- } \\
\text { ness. }\end{array}$ & Depth. \\
\hline 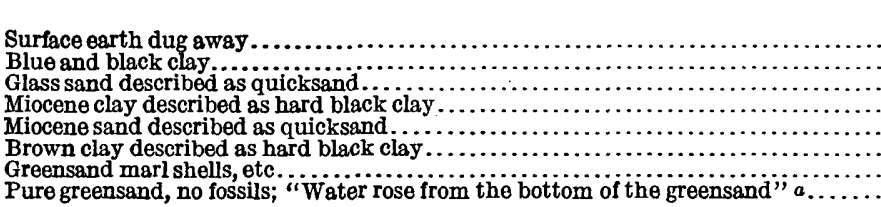 & $\begin{array}{r}\text { Feet. } \\
5 \\
15 \\
95 \\
35 \\
107 \\
43 \\
20 \\
15\end{array}$ & $\begin{array}{r}\text { Feet. } \\
5 \\
20 \\
115 \\
150 \\
257 \\
300 \\
320 \\
335\end{array}$ \\
\hline
\end{tabular}

a Cook, G. H., Geology of New Jersey, p. 291, 1868.

\section{MARLTON DISTRICT.}

SELECTION OF AREA.

In the vicinity of Marlton the area occupied by the combined Hornerstown and Navesink marls expands to a broad belt about 2 miles wide. The greensand may be recognized in the roads and the plowed fields at many places. A number of marl pits were opened in the early days, and the marl was much used. More recently the Atlantic Potash Co. has opened pits, described below, along the railroad, about 1.1 miles east of Marlton, for commercial exploitation of the marl and the extraction of the potash. About 1 mile southeast of Marlton the Vincentown sand emerges from Tertiary cover, though it is still concealed to a greater or less degree by Quaternary deposits.

28 Knapp, G. N., data on fle at the office of the State geologist, Trenton. 
The field of Alphonso Fusco, at Elmwood Road station, about 1.8 miles east of Marlton, was selected for exploration because, so far as could be told from the map and the general appearance of the country, it lies near the contact of Vincentown sand and Hornerstown marl, so that a full thickness of greensand marl might be expected. The overburden, too, was thought to be relatively thin.

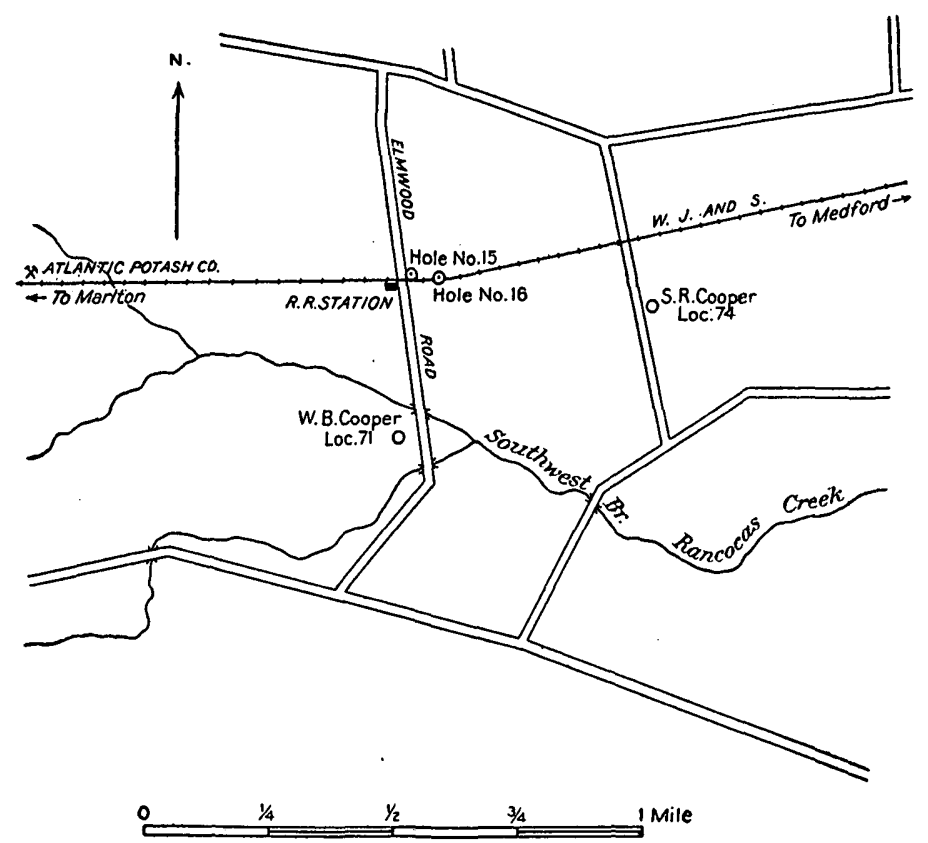

FIGURE 6. - Sketch map of part of the Marlton district, showing the location of holes 15 and 16.

HOTES 15 AND 16.

A 2.5-acre tract was laid out east of the road and north of the railroad, and two holes were sunk 330 feet apart, as indicated in figure 6. A third hole was planned, but the contract for drilling expired before it could be started. The records of holes 15 and 16 follow. 
Records of holes in Marlton district.

Locality 62, hole 15 .

[Farm of Alphonso Fusco, Elmwood Road, 65 feet N. $63^{\circ}$ E. from center of railroad crossing just east of station. Elevation of surface, about 65 feet. R. K. Bailey, analyst; S. J. Taylor, driller.]

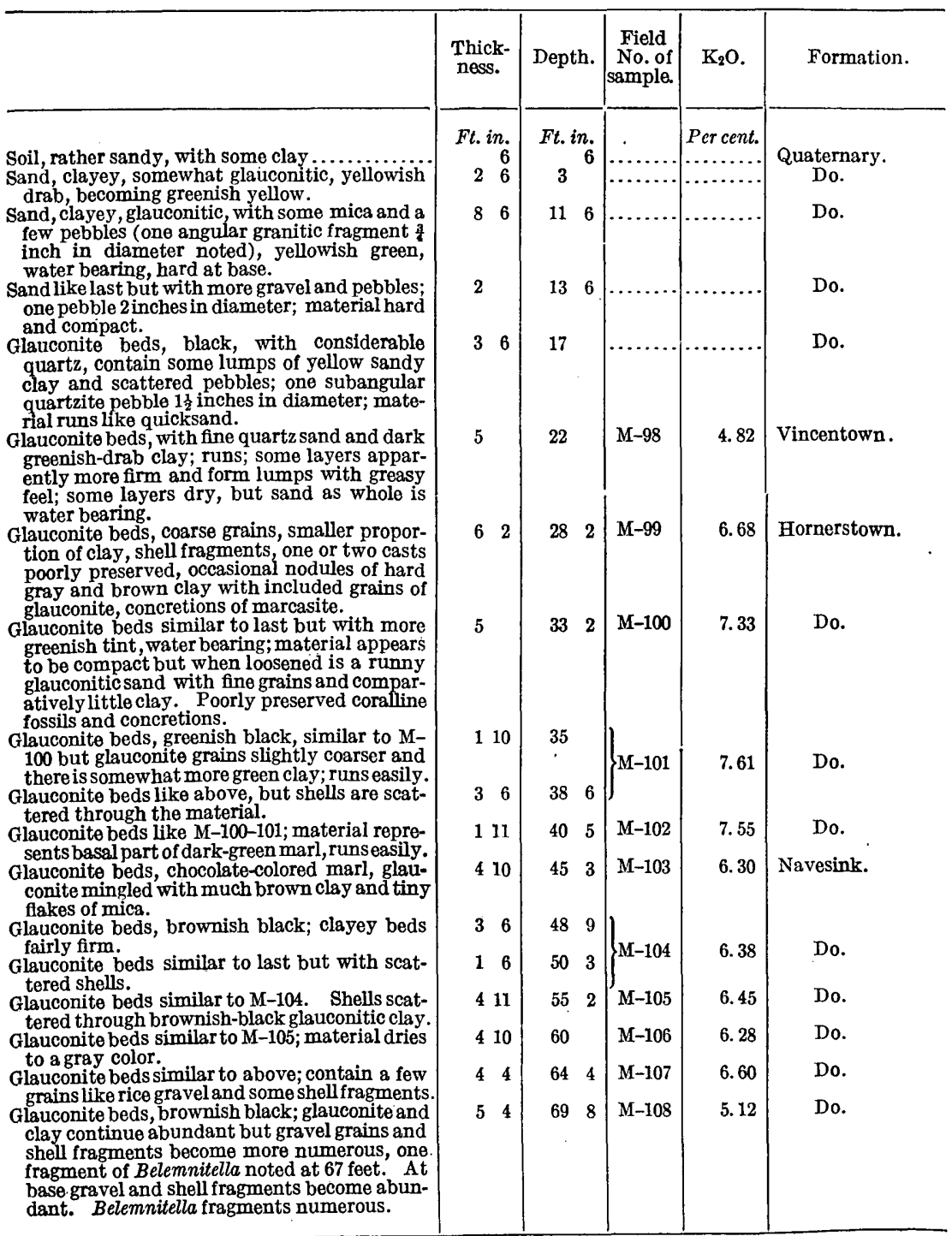


Locality 63, hole 16.

[Farm of Alphonso Fusco, Elmwood Road, 330 feet S. $82^{\circ}$ E. from hole 15. Elevation of surface, about 61 feet. R. K. Bailey, analyst; S. J. Taylor, driller.]

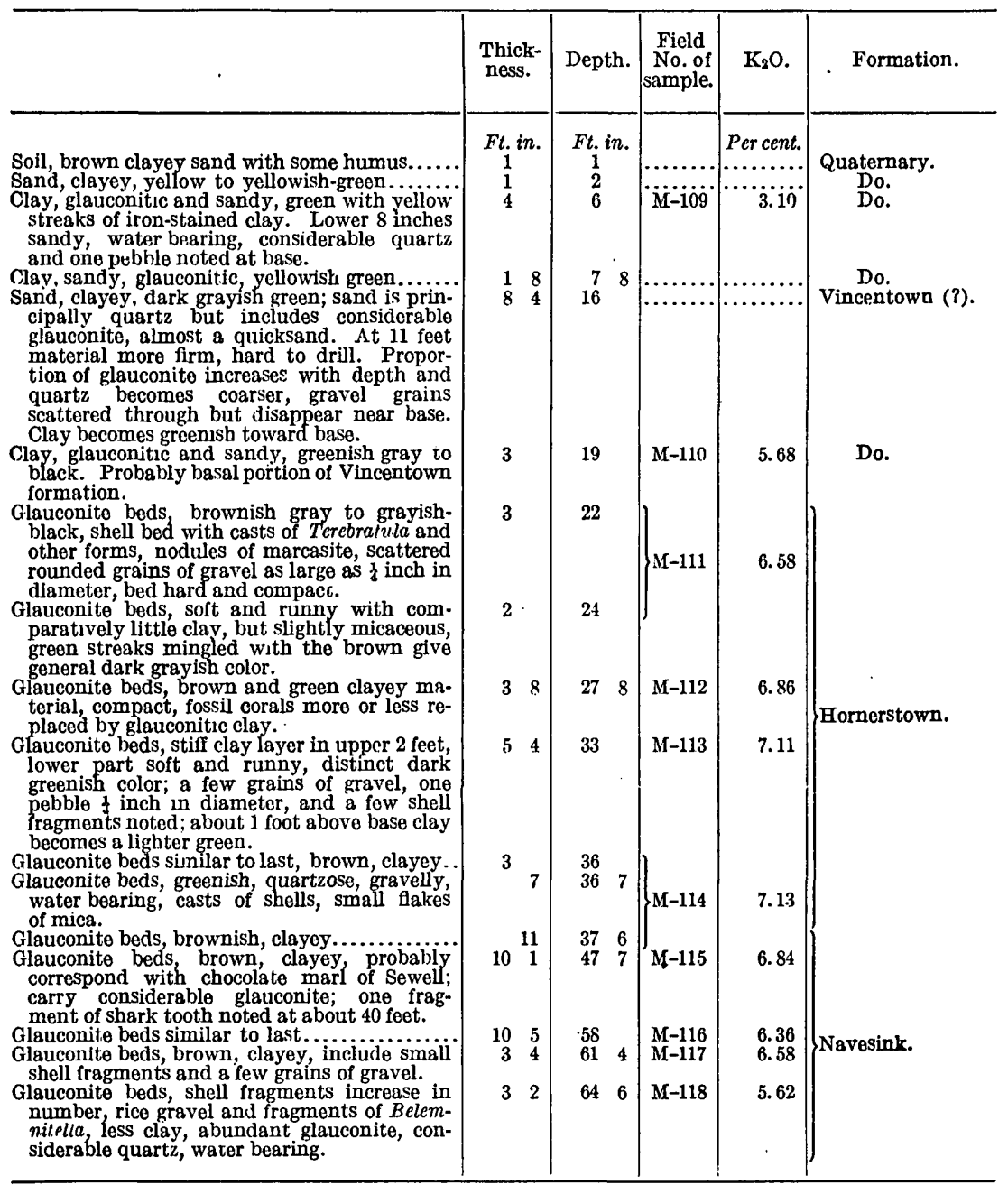


The data furnished by holes 15 and 16 are summarized below:

Thickness and quality of greensand beds at holes 15 and 16, Elmwood Road.

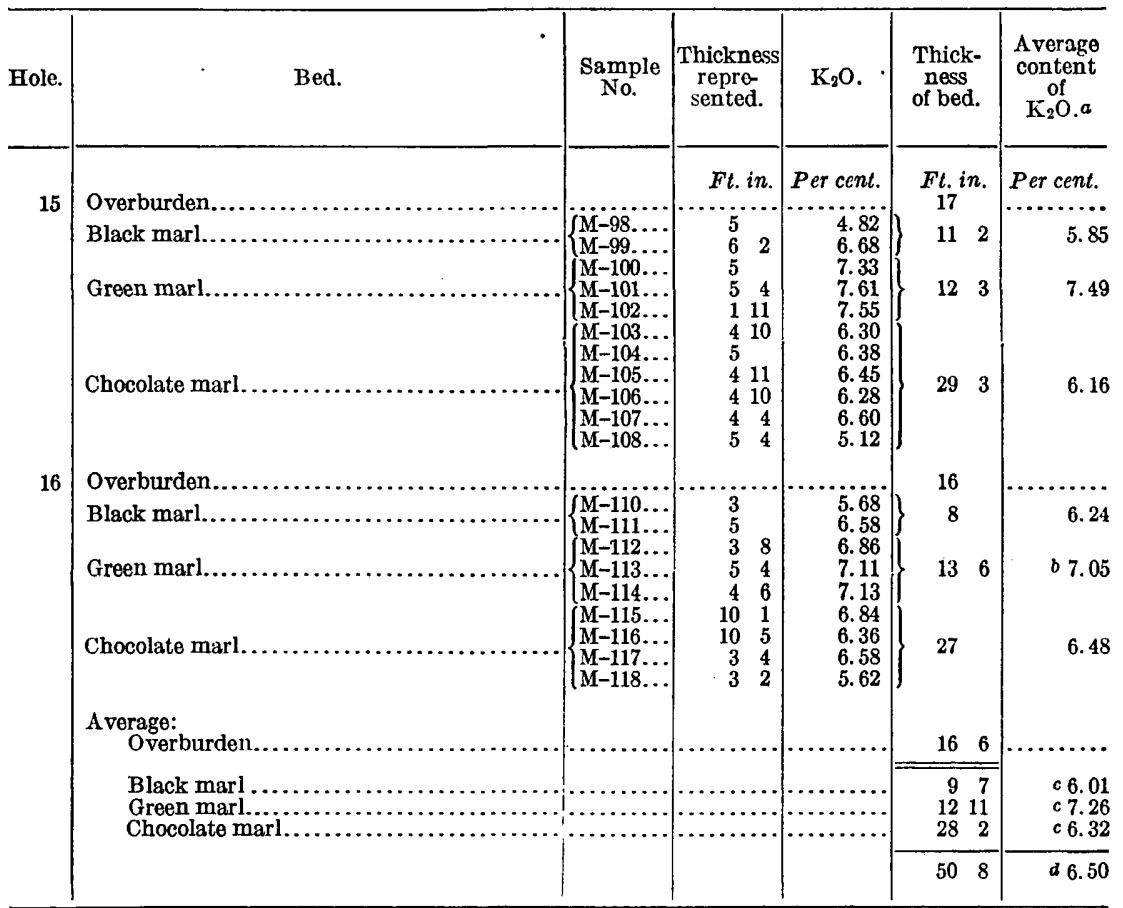

a Average for bed weighted according to the thicknesses represented by the respective samples. $b$ Includes 11 inches of chocolate marl.

c Average for the bed in the 2.5-acre tract weighted according to its thickness at the respective holes.

d Average of entire thickness of marl in the 2.5-acre tract.

As shown in the above table, the maximum thickness of the overburden in the 2.5-acre tract, as inferred from the two holes, is 17 feet and the average is 16.5 feet. The land rises slightly toward the north side of the tract, so that 17 or 17.5 feet would perhaps be a fairer average for the overburden.

The presence of the Terebratula-bearing bed at hole 16 fixes definitely the position of the top of the Hornerstown at 19 feet at that place; the corresponding bed, not so well marked, occurs at 22 feet at hole 15 , where the surface elevation is 4 feet higher (65 feet).

Above the top of the Hornerstown is a bed 5 feet thick at hole 15 and 3 feet thick at hole 16, consisting largely of fine quartz sand and glauconite with more or less clay. This bed is presumably the basal part of the Vincentown sand but may represent reworked material of Pleistocene age. It contains sufficient glauconite to warrant its inclusion with the underlying marl beds, and it is here classed with the black marl.

The black marl has a maximum of 11 feet 2 inches, averages 9 feet 7 inches, and contains 6.01 per cent of potash $\left(K_{2} \mathrm{O}\right)$. The green 
marl has a maximum thickness of 13 feet 6 incnes, averages 12 feet 11 inches, and contains 7.26 per cent of potash. The chocolate marl has a maximum thickness of 29 feet 3 inches, averages 28 feet 2 inches, and contains 6.32 per cent of potash. The entire bed averages 50 feet 8 inches or, for purposes of computation, say 50 feet in thickness and contains 6.50 per cent of potash.

\section{WELI DATA.}

Numerous wells sunk within a radius of 2 or 3 miles of Marlton serve to check the thickness and continuity of the marl and show the general thickness of the overburden in the district. At locality 64 , which is on relatively high ground midway between Marlton and Ashland and southeast of the marl belt as mapped, there is 50 feet of greensand beneath 81 feet of overburden, as shown in the following record : $:^{28}$

Record of well of S. C. Gardiner, about 2.5 miles southwest of Marlton, on road to Ashland (locality 64).

[Elevation, 147 feet. W. C. Barr, driller.]

\begin{tabular}{|c|c|c|c|}
\hline & $\begin{array}{c}\text { Thick- } \\
\text { ness. }\end{array}$ & Depth. & Formation. \\
\hline 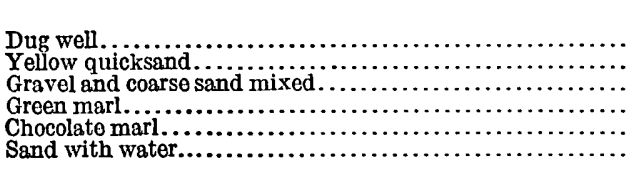 & \begin{tabular}{r|} 
Fect. \\
40 \\
35 \\
6 \\
20 \\
30 \\
6
\end{tabular} & \begin{tabular}{r|} 
Feet. \\
40 \\
75 \\
81 \\
101 \\
131 \\
137
\end{tabular} & $\left\{\begin{array}{l}\text { [Quaternary?] } \\
\text { [Hornerstown and } \\
\text { Navesink.] } \\
\text { [Mount Laurel and } \\
\text { Wenonah.] }\end{array}\right.$ \\
\hline
\end{tabular}

Three wells at Marlton show considerable thicknesses of marl, but they also show a rather thick overburden.

Record of well of H. B. Dunphey, at Marlton (locality 65).a

[Elevation, 105 feet. W. C. Barr, driller.]

\begin{tabular}{|c|c|c|c|}
\hline & $\begin{array}{l}\text { Thick- } \\
\text { ness. }\end{array}$ & Depth. & Formation. \\
\hline 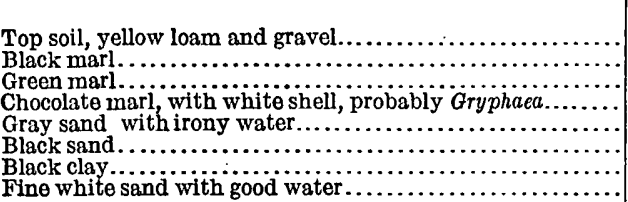 & $\begin{array}{r}\text { Feet. } \\
18 \\
14 \\
9 \\
29 \\
12 \\
40 \\
72 \\
6\end{array}$ & $\begin{array}{r}\text { Feet. } \\
18 \\
32 \\
41 \\
70 \\
82 \\
122 \\
194 \\
200\end{array}$ & $\left\{\begin{array}{l}\text { Pleistocene. } \\
\text { [Hornerstown and } \\
\text { Navesink.] } \\
{[\text { Mount Laurel and }} \\
\text { Wenonah.] } \\
\text { [Marshalltown.] } \\
\text { [Englishtown.] }\end{array}\right.$ \\
\hline
\end{tabular}

a New Jersey Geol. Survey Ann. Rept. for 1895, p. 69, 1896.

If the black marl beneath the gravel is considered part of the Hornerstown there is a thickness of 52 feet of marl beneath an over-

20 New Jersey Geol. Survey Ann. Rept. for 1896, p. 143, 1897. $88625^{\circ}-22-6$ 
burden of 18 feet. The records of the well at locality 66 and of hole 16 suggest that this black marl may perhaps more properly be assigned to the Kirkwood or the Vincentown.

\section{Record of well at waterworks, Marlton (locality 66).a}

[About 0.6 mile south of railroad station. Elevation, 115 feet(?). A. G. Dunphey, driller.]

\begin{tabular}{|c|c|c|c|}
\hline & $\begin{array}{l}\text { Thick- } \\
\text { ness. }\end{array}$ & Depth. & Formation. \\
\hline 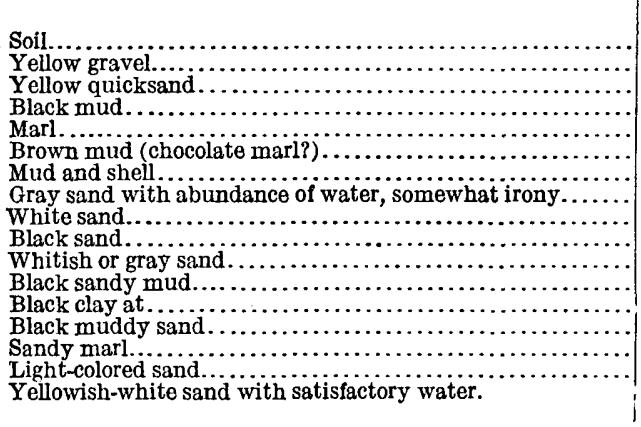 & $\begin{array}{r}\text { Fcet. } \\
9 \\
5 \\
15 \\
20 \\
25 \\
19 \\
3 \\
10 \\
1 \\
1 \\
17 \\
(30) \\
(30) \\
(11) \\
(12) \\
(4)\end{array}$ & $\begin{array}{r}\text { Fcct. } \\
9 \\
14 \\
29 \\
49 \\
74 \\
93 \\
96 \\
106 \\
107 \\
108 \\
125 \\
(155) ? \\
(185) ? \\
(196) ? ? \\
(208) ? \\
(212) ?\end{array}$ & $\left\{\begin{array}{l}{[\text { Quaternary?] }} \\
{[\text { Kirkwood?] }} \\
{\left[\begin{array}{l}\text { Hornerstown and } \\
\text { Navesink.] }\end{array}\right.} \\
{\left[\begin{array}{l}\text { Wount Laurel and } \\
\text { Wenonah.] }\end{array}\right.} \\
{\left[\begin{array}{l}\text { [Marshalltown?] } \\
\text { [Englishtown?] }\end{array}\right.}\end{array}\right.$ \\
\hline
\end{tabular}

a New Jersey Geol. Survey Ann. Rept. for 1897, pp. 259-260, 1898.

Here there is 47 feet of marl beneath 49 feet of overburden.

The writer is indebted to M. W. Twitchell for the following record and interpretation of the neighboring well of T. R. Wills:

\section{Record of well of T. R. Wills, near Marlton (locality 67).}

[Five-eighths of a mile south of Mariton. Elevation, 100 feet. A. G. Dunphey, driller.]

\begin{tabular}{|c|c|c|c|}
\hline . & $\begin{array}{l}\text { Thick- } \\
\text { ness. }\end{array}$ & Depth. & Formation. \\
\hline 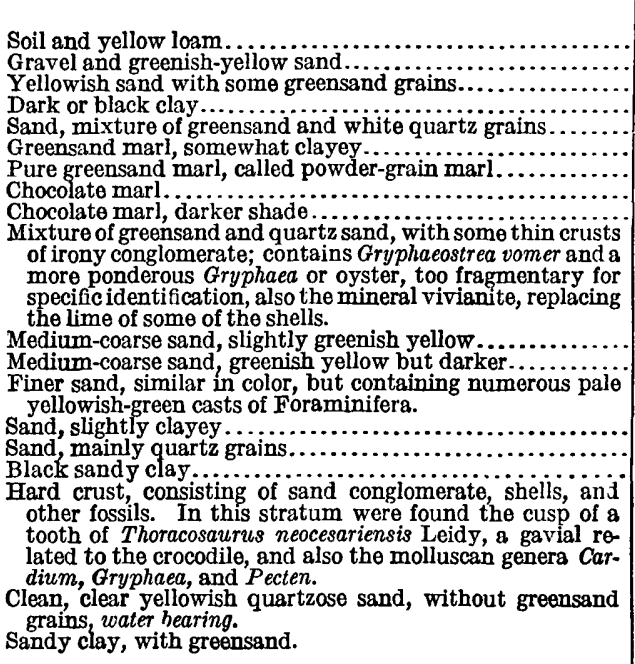 & $\begin{array}{r}\text { Feet. } \\
12 \\
3 \\
7 \\
10 \\
4 \\
14 \\
10 \\
8 \\
14 \\
5 \\
\\
\\
\\
9 \\
2 \\
20 \\
12 \\
13 \\
52 \\
1\end{array}$ & $\begin{array}{r}\text { Feet. } \\
12 \\
15 \\
22 \\
32 \\
36 \\
50 \\
60 \\
68 \\
82 \\
87\end{array}$ & $\left\{\begin{array}{l}\text { Kirkwood. } \\
\text { Hornerstown and Nav- } \\
\text { esink. }\end{array}\right.$ \\
\hline
\end{tabular}


At this locality the top of the Hornerstown is not present, but there is 46 feet of greensand beneath 36 feet of overburden, consisting of Kirkwood sand.

A well sunk for Joseph Evans, about 1.5 miles southeast of Marlton, furnishes the following record:

Record of well of Joseph Evans, 1.5 miles southeast of Marlton (locality 68).a

[Elevation, 129 feet.]

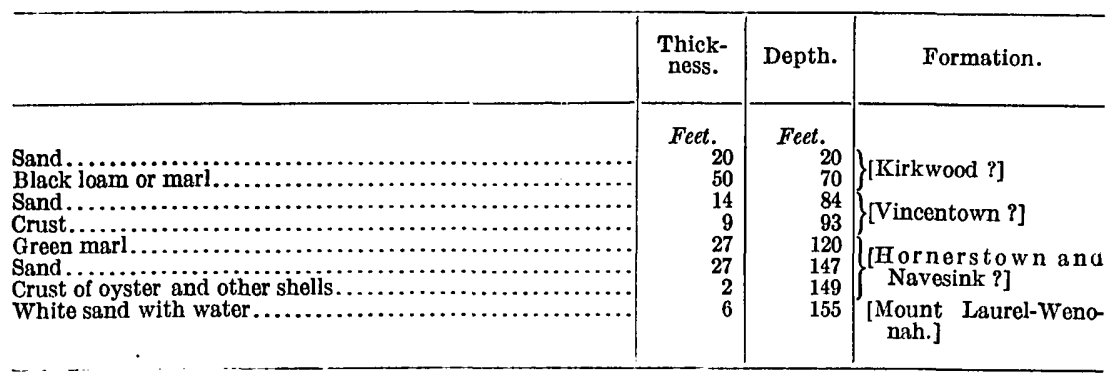

a New Jersey Geol. Survey Ann. Rept. for 1894, pp. 214-215, 1895.

If the writer's interpretation of the above record is correct there is 54 feet of greensand marl beneath 93 feet of overburden. The "crust" at a depth of 84 feet is thought to be the more massive limesand phase of the Vincentown, but it may represent the shell bed at the top of the Hornerstown. The shell bed at a depth of 147 feet is probably the base of the Navesink.

Record of well of J. W. Barr, about 2 miles east of Marlton (locality 69). ${ }^{a}$

[Elevation, 70 feet.]

\begin{tabular}{|c|c|c|c|}
\hline 1 & $\begin{array}{l}\text { Thick- } \\
\text { ness. }\end{array}$ & Depth. & Formation. \\
\hline 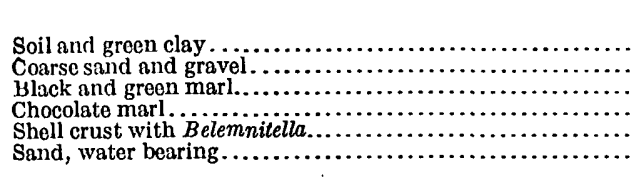 & $\begin{array}{r}\text { Feet. } \\
10 \\
10 \\
14 \\
30 \\
4\end{array}$ & $\begin{array}{r}\text { Feet. } \\
10 \\
20 \\
34 \\
64 \\
68 \\
\ldots .\end{array}$ & $\left\{\begin{array}{l}{[Q \text { uaternary.] }} \\
{[\text { Hornerstown and }} \\
\text { Navesink.] } \\
\text { [Mount Laurel and } \\
\text { Wenonah]. }\end{array}\right.$ \\
\hline
\end{tabular}

a New Jersey Geol. Survey Ann. Rept. for 1894, p. 209, 1895.

The upper shell bed is not present at this locality, but beneath 20 feet of clay, sand, and gravel there is 48 feet of greensand marl, including the lower shell bed.

The records of a number of other wells in the vicinity of Marlton, so far as they relate to the marl and its overburden, are summarized in the following table. 
Thickness of overburden and of marl at several wells near Marlton.

\begin{tabular}{|c|c|c|c|c|c|}
\hline $\begin{array}{c}\text { Local- } \\
\text { ity. }\end{array}$ & $\begin{array}{l}\text { Reference (New } \\
\text { Jersey Geol. Survey } \\
\text { Ann. Rept.). }\end{array}$ & Owner. & $\begin{array}{l}\text { Over- } \\
\text { bur- } \\
\text { den. }\end{array}$ & Marl. & Driller. \\
\hline $\begin{array}{c}70 \\
70 \mathrm{a} ? \\
\ldots \ldots \ldots \\
\cdots \cdots \cdots \\
\cdots \cdots \cdots \\
71 \\
72 ? \\
73 \\
\cdots \cdots \cdots \\
\cdots \cdots \cdots \\
74\end{array}$ & 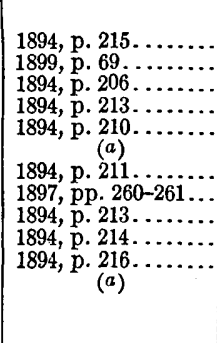 & 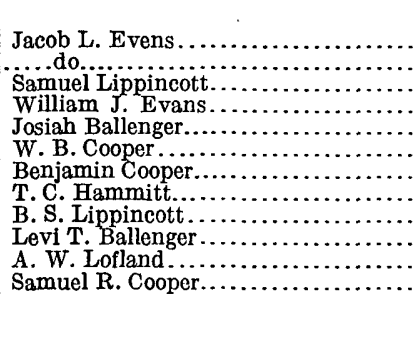 & $\begin{array}{c}\text { Feet. } \\
40 \\
7 \\
26 \\
50 \\
30 ? \\
20 \pm \\
31 \\
85 \\
50 \\
20+ \\
58 \\
30 \\
37\end{array}$ & $\begin{array}{c}\text { Feet. } \\
\quad 58 ? \\
51 \\
54 \\
67 \\
40 \\
50 \\
35 ? \\
42 \\
45 \\
56 ? \\
37 \\
50 \\
49\end{array}$ & $\begin{array}{l}\text { A. G. Dunphey. } \\
\text { W. C. Barr. } \\
\text { Do. } \\
\text { Stotthoff Bros. } \\
\text { J. W. Barr. } \\
\text { A. G. Dunphey. } \\
\text { W. C. Barr. } \\
\text { Do. } \\
\text { Do. }\end{array}$ \\
\hline
\end{tabular}

a Personal communication.

Definite locations for a number of these wells are not available, but they all lie within 3 miles of Marlton and mostly to the east or southeast. They are near the southeast boundary of the marl belt and show an average thickness of about 49 feet of marl beneath about 37 feet of overburden, which, at several of the wells, consists in part of Vincentown and Kirkwood sands.

\section{OT HER DATA.}

Some of the marl exposed in plowed fields and along roads near Marlton is reworked material of Pleistocene age that might readily be mistaken for marl in place. For example, at locality 75, between Marlton and Evesboro, Dr. Kümmel noted in 1915 a good exposure of reworked marl 2 feet thick resting on a bed of yellow iron-stained gravel also about 2 feet thick. In the old marl pits in that vicinity the only exposures at present show reworked marly clay with pockets of gravel. The real marl occurs below the floor of the pits at an elevation of about 90 feet and beneath the gravel.

The pits of George T. Middleton, at locality 76, about 1.1 miles $\mathrm{N}$. $78^{\circ}$ E. from Marlton station, are entered from the Evesboro-Medford road. According to information furnished to Dr. Kümmel in 1917 these pits have not been dug recently, but the marl lies near the surface with only 2 or 3 feet of overburden and no shell bed. The marl was formerly dug to a depth of 12 feet, where water interfered with digging, but the marl was said to be much thicker and to contain more than 7 per cent of potash.

ATLANTIC POTASH CO.'S PIT.

The pit of the Atlantic Potash Co. lies about 1.1 miles due east of Marlton, at locality 77, just north of the railroad. At the time of the writer's visits, in October, 1918, and January and March, 1919, the 


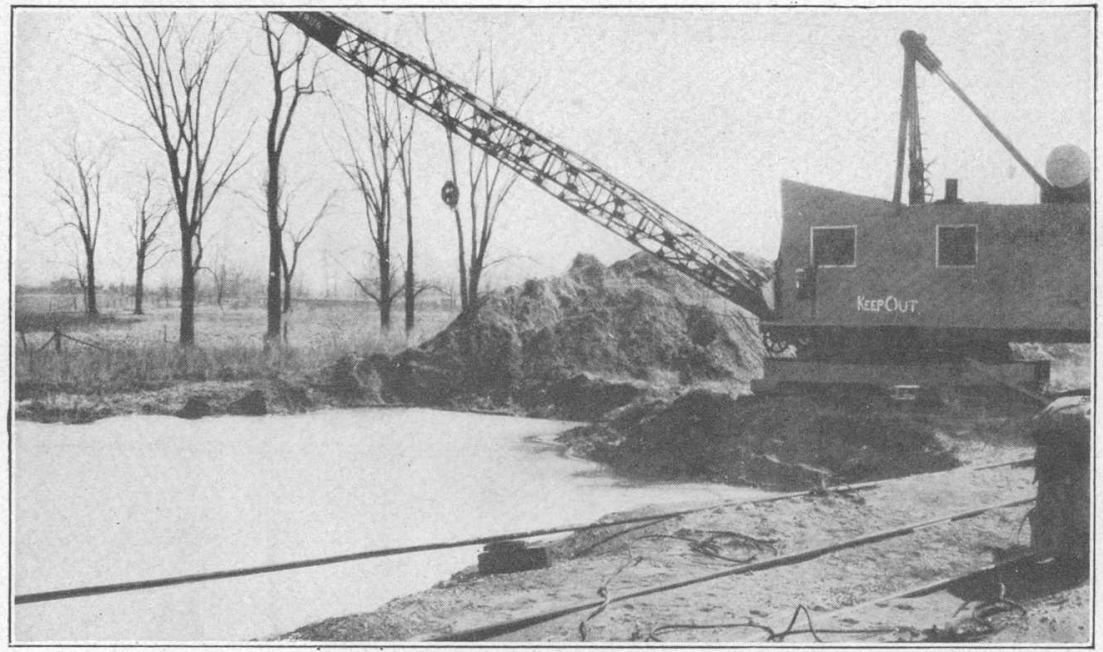

A. DREDGE, PIT, AND STOCK PILE OF ATLANTIC POTASH CORPORATION ABOUT 1.1 MILES EAST OF MARLTON, BURLINGTON COUNTY, N. J.

Note abundance of water in pit.

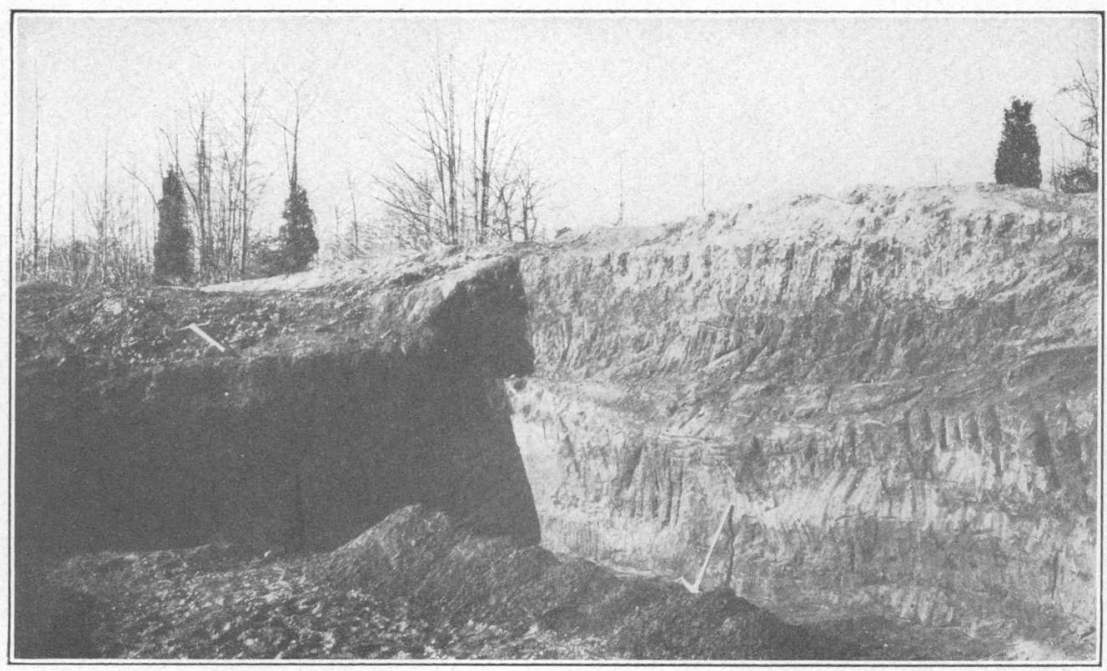

B. RECENT DIGGING AT NORTHWEST CORNER OF WEST JERSEY MARL \& TRANSPORTATION CO.'S MARL PIT NEAR SEWELL, GLOUCESTER COUNTY, N. J. 
pit was filled with water. In September, 1917, fresh surfaces were exposed and Dr. Kümmel measured the following section:

Section at pit of Atlantic Potash Co., 1.1 miles east of Marlton (locality 77).

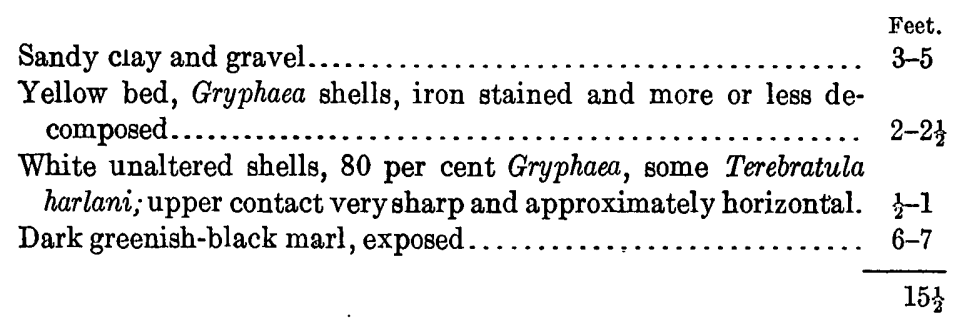

It was stated that 40 feet of marl had been dug here without reaching bottom, and that about 13 feet from the top the marl became a little more greenish.

The condition of the pit in March, 1919, is shown in Plate VIII, A. Determinations of the weight of the marl per cubic foot were made on relatively fresh run of mine material, as described on pages 19-20. A sample of this material analyzed at the Survey laboratories contained 7.63 per cent of potash $\left(\mathrm{K}_{2} \mathrm{O}\right)$.

\section{IIME SAND.}

The lime sand does not come to the surface in the Marlton district, but it is penetrated in a number of wells in the eastern and southeastern parts of the district. The map shows its probable distribution northeastward from a place about 1 mile southeast of Marlton, where it emerges from beneath Tertiary beds but is still concealed by Quaternary deposits.

\section{ESTIMATES OF TONNAGE AND VALUE.}

In the 2.5-acre tract at Elmwood Road station the thickness of the marl is about 50 feet and its potash content 6.50 per cent. On the assumptions, as in previous estimates, of 28 per cent of voids and a weight of 133 pounds per cubic foot, 1 acre of this tract would contain $\frac{43,560 \times 50 \times 133 \times 0.065}{2,000}=9,400$ tons of potash $\left(\mathrm{K}_{\mathbf{2}} \mathrm{O}\right)$ and the 2.5-acre tract would contain 23,500 tons.

With an 80 per cent recovery and a price of $\$ 2.50$ per unit of 20 pounds (March, 1920) the potash in a ton of greensand would be worth $\$ 13$ and the potash in an acre of this tract would be worth $\$ 1,880,000$. At the more probable price of $\$ 1.50$ per unit the potash in a ton of greensand would be worth $\$ 7.80$ and the potash in an acre of the ground would be worth $\$ 1,128,000$. These estimates of value have no relation to the present value of the land, as they are dependent upon the extraction of the potash by processes whose successful operation has not been commercially demonstrated. 
UTIIZATION OF THE DEPOSITS.

The 2.5-acre tract is part of a tract large enough for commercial development and lies on a railroad that gives direct access to Delaware River at Camden, about 16 miles distant.

At holes 15 and 16 and at the Atlantic Potash Co.'s pits water rises within a few feet of the surface and will need to be considered in any plan for exploitation of the marl.

Along the southeast boundary of the marl belt a thickness of about 50 feet of marl may be expected, but the overburden is relatively thick, being about 17.5 feet in the 2.5-acre tract. Where streams have removed some of the overburden, as in the vicinity of the Atlantic Potash Co.'s pits, the marl will be more accessible.

\section{MEDFORD DISTRICT.}

\section{MARL LOCALITIES.}

The Medford district merges with the Marlton district on the west and is discussed separately only for convenience in the presentation of data. At Medford the Manasquan marl underlies the surface sand and gravel, but to the south, east, and northeast the Kirkwood is found. The Manasquan forms a belt extending nearly 4 miles southwest of Medford, but the marl is only locally exposed. It was formerly dug here and there, as at locality 78, about 1 mile southwest of the town. This locality was visited by Dr. Kümmel in September, 1917, when he found the pits entirely grown up with trees and no marl visible. The marl was deeply buried by yellow sand and must have lain 12 to 15 feet below the surface.

Just north of Medford the Vincentown sand forms a belt about a mile wide that is also largely concealed by surface sand and gravel. From the vicinity of Reeves station to a point within a mile of Lumberton the Hornerstown and Navesink marls occupy a belt about 2 miles wide, in which the marl lies under varying amounts of sand and gravel and in some places is within a few feet of the surface.

\section{WELL DATA.}

The records of several wells show the thickness of the overburden and of the marl in different parts of the district. The writer is indebted to M. W. Twitchell for the following record and interpretation of the well of J. S. Wills: 
Record of well of J. S. Wills, near Medford (locality 79).

[Elevation, 63 (?) feet.]

\begin{tabular}{|c|c|c|c|}
\hline & $\begin{array}{c}\text { Thick- } \\
\text { ness. }\end{array}$ & Depth. & Formation. \\
\hline 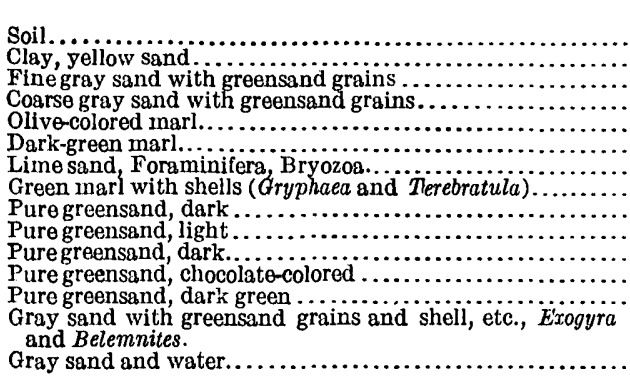 & 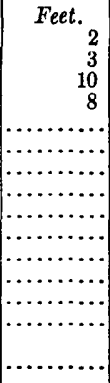 & $\begin{array}{r}\text { Feet. } \\
2 \\
5 \\
15 \\
23 \\
30 \\
35 \\
50 \\
70 \\
76 \\
80 \\
91 \\
104 \\
120 \\
124 \\
126\end{array}$ & $\left\{\begin{array}{l}\text { Kirkwood. } \\
\text { Manasquan. } \\
\text { Vincentown. } \\
\text { H ornerstown and } \\
\text { Navesink. }\end{array}\right.$ \\
\hline
\end{tabular}

This record shows a thickness of about 54 feet of Hornerstown and Navesink marl beneath an overburden of 70 feet; but included in the overburden are about 20 feet of Manasquan marl and 20 feet of Vincentown sand.

At the farm of I. W. Stokes (locality 80), about 1 mile northeast of Medford, a well was sunk in the midst of the Hornerstown and Navesink marl belt. This shows 15 feet of overburden and 30 feet of marl, a commercial quantity. The following record and interpretation are supplied by Dr. Twitchell:

Record of well of $I$. W. Stokes, near Medford (locality 80).

[Elevation, 78 feet. Stotthoff Bros., drillers.]

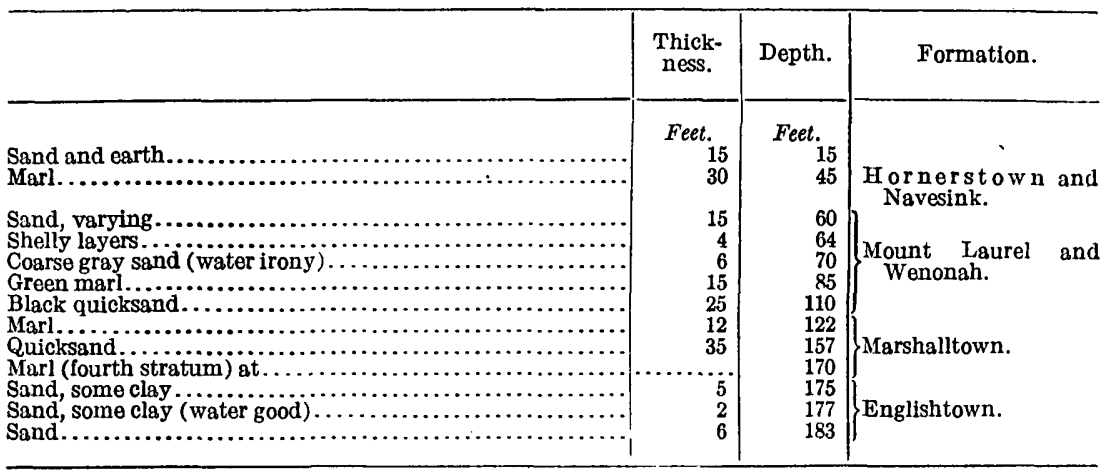


At the Eayrestown School, about 1.2 miles northeast of Eayrestown, a well was sunk, which, according to the State Survey files, furnishes the following record:

Record of well at Eayrestown School (locality 81).

[Elevation, about 45 feet. S. J. Taylor, driller.]

\begin{tabular}{|c|c|c|c|}
\hline & $\begin{array}{l}\text { Thick- } \\
\text { ness. }\end{array}$ & Depth. & Formation. \\
\hline 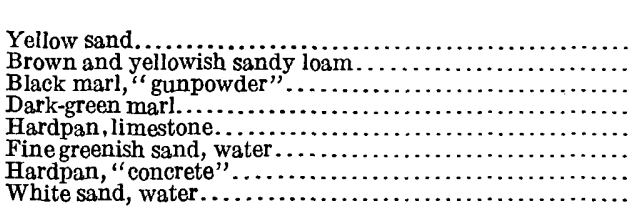 & $\begin{array}{r}\text { Feet. } \\
5 \\
15 \\
20 \\
10 \\
1 \\
10 \\
1 \\
14\end{array}$ & $\begin{array}{r}\text { Feet. } \\
5 \\
20 \\
40 \\
50 \\
51 \\
61 \\
62 \\
76\end{array}$ & $\left\{\begin{array}{l}{[\text { Quaternary. }]} \\
{[\text { Horners tow n and }} \\
\text { Navesink.] } \\
{\left[\begin{array}{l}\text { Mount Laurel and } \\
\text { Wenonah.] }\end{array}\right.}\end{array}\right.$ \\
\hline
\end{tabular}

The overburden at this site is relatively thick (20 feet). The marl is 31 feet thick and from the descriptive terms used is probably of good quality. In view of the thickness shown it is probable that the marl extends farther northwest than is shown on the map.

R. S. RYAN CO.'S PIT.

The pit of the R. S. Ryan Co., which formerly belonged to Edward Rogers, of Medford, is at Reeves station, about 2 miles north of Medford (locality 82), and is now the site of a plant for the extraction of potash from greensand:marl. (See Pl. IX, A.) At the north end of the pit the following section was observed in March, 1919:

Section at pit of R. S. Ryan Co., at Reeves station (locality 82).

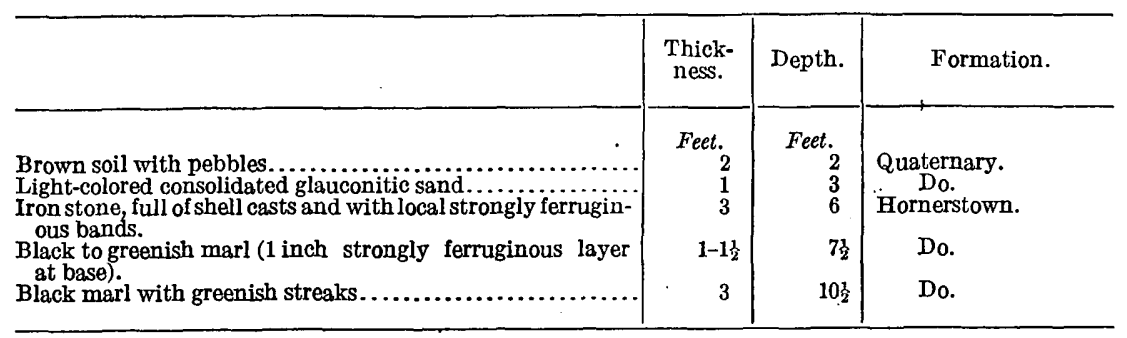

The pit has been dug below the level of the base of the above section, but the lower part is concealed by water. The marl is said to be 40 feet thick and to contain from $6 \frac{1}{2}$ to 7 per cent of potash $\left(K_{2} \mathrm{O}\right)$. Material from the lower layer in the section was used in the weight determinations described on page 19. An average sample of fresh marl from this layer analyzed in the Survey laboratory contained 6.25 per cent of potash.

The ironstone layer, which in the above section coincides with the position of the shell bed at the top of the Hornerstown, becomes 


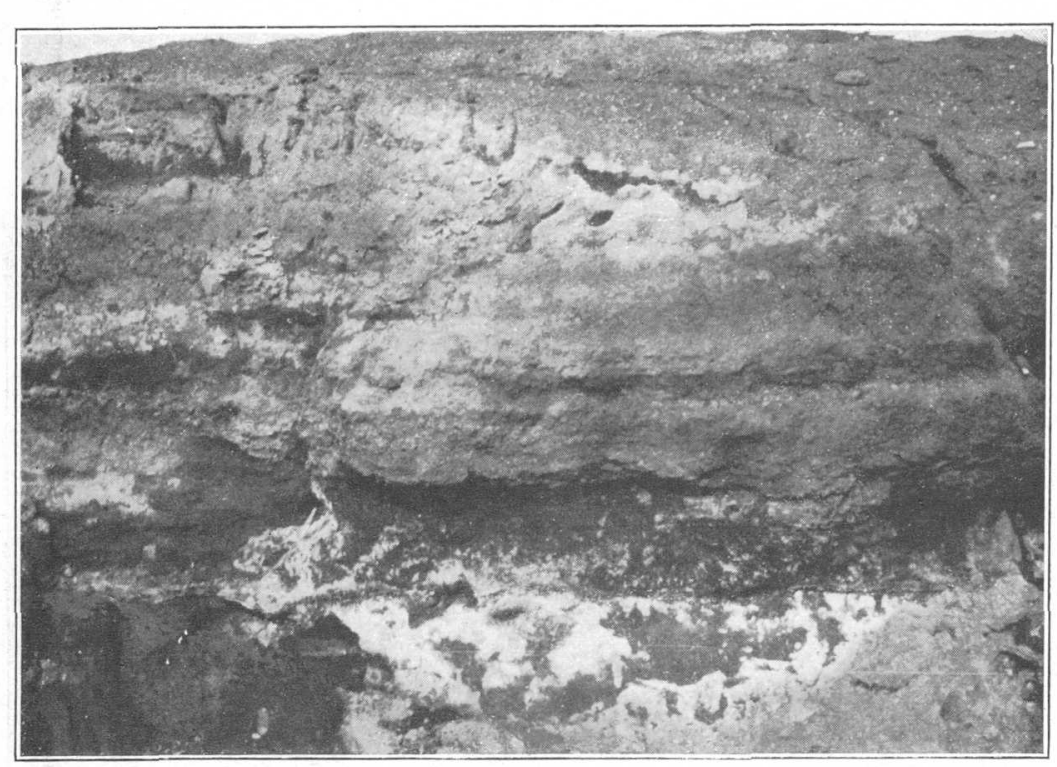

A. NORTH END OF PIT AT R. S. RYAN CO.'S PLANT AT REEVES STATION,
BURLINGTON COUNTY, N. J.

Showing ironstone overlying locally eflloreseent greensand.

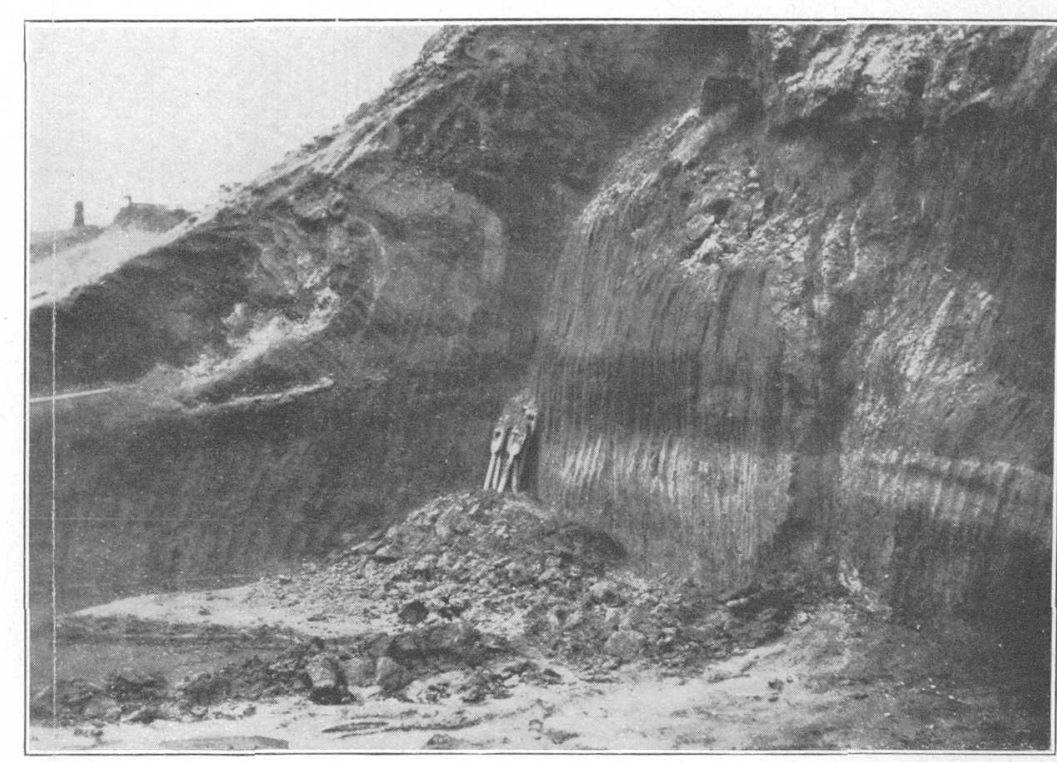

B. NORTHWEST CORNER OF RECENT OPENING OF WILLIAM HOFFMAN'S

Showing efllorescence and stratification of the greensand and creep along the face of the
old bank, indicated by the contortion of sand-fileded crevicess.

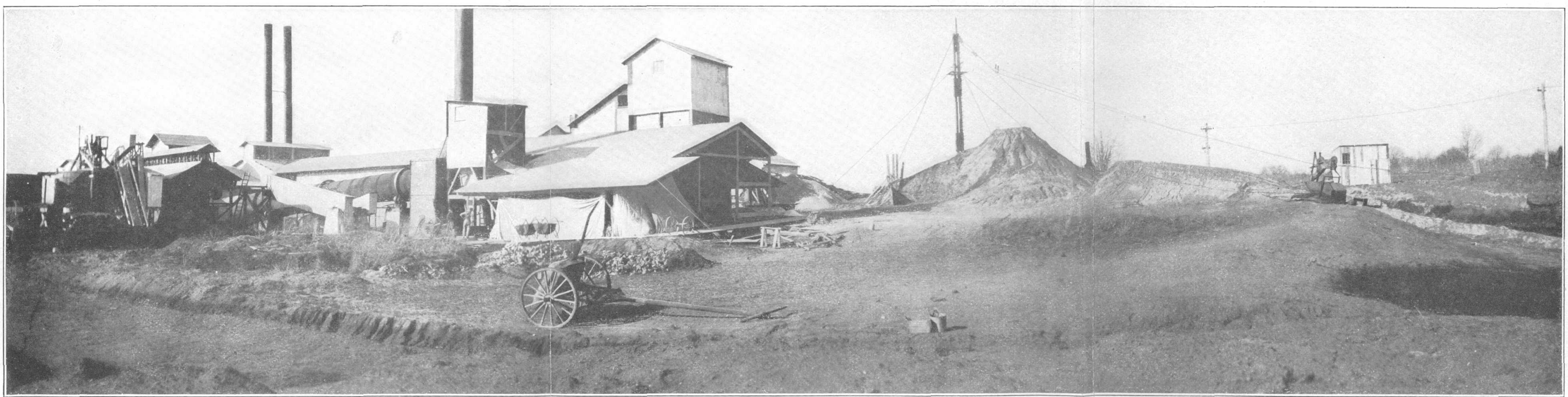

D. POTASH PLANT OF R. S. RYan CO. AT REEVES Station, BURLINGTON COUNTY, N. J. 
thinner southward and is only about 6 inches thick at the south end of the pit. At that place the shells are missing, and the ironstone includes pebbles. Thus the ironstone appears to cut across the upper beds of the marl at a faint angle, rising toward the north.

The layer from which the sample analyzed came is in the upper part of the Hornerstown marl. Comparison with the borings previously described would indicate that marl of better quality would be found a few feet lower.

\section{LIME SAND.}

The Vincentown sand with its lime-sand phase is reported in the logs of some of the wells already cited. In this district it is exposed only in the pit at locality 83, on Haynes Creek about 0.4 mile southeast of the R. S. Ryan Co.'s pit just described, with which it is connected by a tramway. The lime-sand pit also belongs to the R. S. Ryan Co., and the lime sand is used with the greensand in the process of potash extraction.

The exposure shows about 8 feet of lime and quartz sand with hard, cemented masses of lime sand 6 inches to 1 foot thick, irregularly distributed through it. There are also large bodies of dark-greenish clay, grading into sand and here and there containing small masses of limestone. Clay bodies 10 feet or more long and 2 or 3 feet thick lie near the base of the cut. A random sample of the loose lime sand analyzed in the Survey laboratory contained 35 per cent of carbonate of lime $\left(\mathrm{CaCO}_{3}\right)$, and a similar sample of the harder limestone phase contained 74 per cent. The analysis of the harder sample gave 52 per cent of lime $(\mathrm{CaO})$, of which only about 32 per cent is in the carbonate form. The excess lime, 20 per cent, is probably present as phosphate, for a qualitative test shows a strong reaction for phosphoric acid. Some iron is also present and may be combined with carbon dioxide $\left(\mathrm{CO}_{2}\right)$. The loose lime sand contains only a small excess of lime. The presence of phosphate of lime in the lime sand may account for its irregular consolidation and also in part for its beneficial action in agriculture.

\section{VINCENTOWN.}

Vincentown lies partly in the area of the Manasquan marl and partly in that of the Vincentown sand. Both marl and lime sand have been dug near the town, but these formations are only locally exposed.

WELI DATA.

A few wells sunk near Vincentown give an idea of the amount and character of the overburden and of the thickness of the lime sand and marl beds. The well of William J. Irick, about a mile west of 
Vincentown, penetrates the Navesink marl and shows the succession of overlying beds. Its record follows:

Record of well of William J. Irick, about 1 mile west of Vincentown (locality 84). ${ }^{a}$

[Elevation, 30 feet. A. G. Dunphey, driller.]

\begin{tabular}{|c|c|c|c|}
\hline & $\begin{array}{c}\text { Thick- } \\
\text { ness. }\end{array}$ & Depth. & Formation. \\
\hline 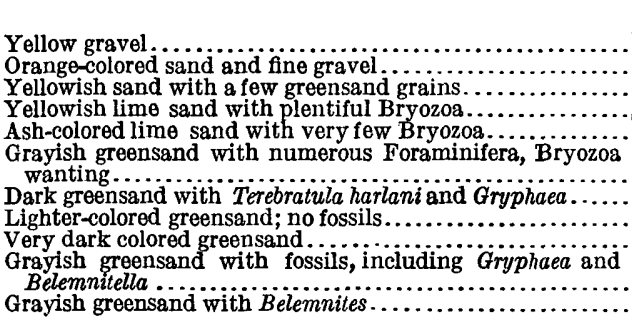 & $\begin{array}{r}\text { Feet. } \\
3 \\
6 \\
9 \\
7 \\
19 \\
\\
5 \\
1 \\
20 \\
31 \\
3 \\
5\end{array}$ & $\begin{array}{r}\text { Feet. } \\
3 \\
9 \\
18 \\
25 \\
44 \\
\\
49 \\
50 \\
70 \\
101 \\
104 \\
109\end{array}$ & $\left\{\begin{array}{l}{[\text { Quaternary.] }} \\
\text { [Vincentown.] }\end{array}\right.$ \\
\hline
\end{tabular}

a New Jersey Geol. Survey Ann. Rept. for 1901, p. 71.

Here beneath an overburden of 18 feet of sand and gravel, including probably the upper bed of the Vincentown, there are 31 feet of lime sand and 55 feet of greensand marl, including both shell beds.

A well sunk at Richard Ridgway's farm, south of Vincentown, shows, as reported, some 90 feet of marl beneath 12 feet of overburden. Its record follows:

Record of well of Richard Ridgway, about 1.75 miles south of Vincentown (locality 85). ${ }^{a}$

[Elevation, about 40 leet. S. J. Taylor, driller.]

\begin{tabular}{|c|c|c|c|}
\hline & $\begin{array}{l}\text { Thick- } \\
\text { ness. }\end{array}$ & Depth. & Formation. \\
\hline 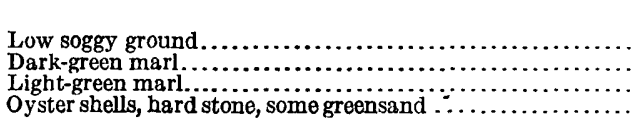 & $\begin{array}{r}\text { Feet. } \\
12 \\
20 \\
70 \\
10\end{array}$ & $\begin{array}{r}\text { Feet. } \\
12 \\
32 \\
102 \\
112\end{array}$ & $\left\{\begin{array}{l}{[\text { Quaternary.] }} \\
\{\text { M a n a s q u a n and } \\
\text { Vincentown?). } \\
\text { [Top of Hornerstown? }\end{array}\right.$ \\
\hline
\end{tabular}

a Files of New Jersey Geol. Survey.

This well is about 2 miles farther down the dip than the Irick well and would thus be expected to show a greater thickness of the Vincentown sand, which is locally very glauconitic, and a complete or nearly complete thickness of Manasquan marl. The limesand phase of the Vincentown, if present, was not recognized. It is possible that the Vincentown is absent and that the shell bed mentioned is the base of the Navesink, but in view of the records of the Irick well and that of Henry I. Budd, given below, the interpretation indicated seems more probable. 
The well of Edward Blackley, at locality 86, near that of Richard Ridgway, shows a similar record but was sunk to a depth of 135 feet. The driller reports that the oyster shells were not so plentiful and that a little black muck was penetrated before reaching the sand, which was of a gray color.

The well of Henry I. Budd, ${ }^{30}$ described as 2 miles south of Birmingham, is probably within 2 miles of Vincentown and somewhat northwest of the strike of the beds at the two wells last mentioned. At the Budd well the base of the Navesink is struck at the depth of 140 feet. Its record follows.

Record of well of Henry I. Budd, 2 miles south of Birmingham.

[Elevation, 50 feet.]

\begin{tabular}{|c|c|c|c|}
\hline & $\begin{array}{l}\text { Thick- } \\
\text { ness. }\end{array}$ & Depth. & Formation. \\
\hline 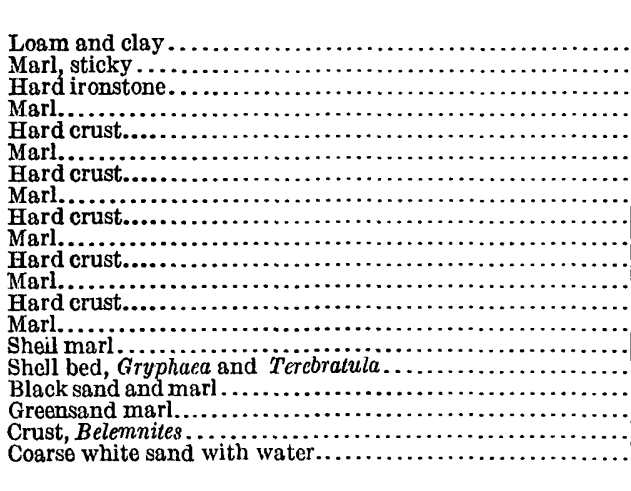 & $\begin{array}{r}\text { Feet. } \\
7 \\
62 \\
2 \\
1 \\
1 \\
2 \\
1 \\
3 \\
1 \\
2 \\
1 \\
2 \\
1 \\
3 \\
10 \\
6 \\
10 \\
23 \\
2 \\
3\end{array}$ & $\begin{array}{r}\text { Eeet. } \\
7 \\
69 \\
71 \\
72 \\
73 \\
75 \\
76 \\
79 \\
80 \\
82 \\
83 \\
85 \\
86 \\
89 \\
99 \\
105 \\
115 \\
138 \\
140 \\
143\end{array}$ & 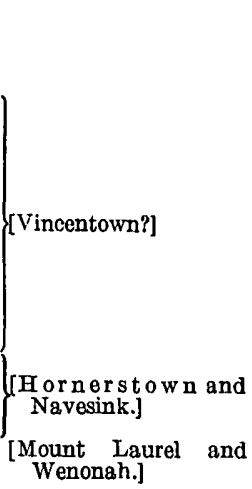 \\
\hline
\end{tabular}

In this well the position of the top of the Hornerstown is clearly indicated by the Terebratula-bearing bed, and the combined Hornerstown and Navesink beds are thus 41 feet thick. The alternating marl and crust layers above this bed are suggestive of the lime-sand and limestone phases of the Vincentown, which under this interpretation would be 28 feet thick. The 62 feet of "sticky marl" is probably too thick to represent only the Manasquan marl and may include the lower and more clayey portion of the Kirkwood. The ironstone, however, suggests unconformity, so that the Manasquan may be absent.

MARL PITS.

At locality 87, about 1 mile south of Vincentown, on the property of Dr. J. Clifford Haines, Dr. Kümmel observed, in September, 1917, 
a freshly dug pit with vertical walls in which the following section was exposed:

Section at marl pit of Dr. J. Clifford Haines, 1 mile south of Vincentown (locality 87).

Sand and gravel....................................... 5

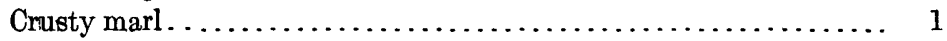

Gray to black marl........................... 3-4

Water level.

10 .

Other exposures in the neighborhood showed 10 to 12 feet of stripping.

In the early eighties, according to data on file at the New Jersey Geological Survey, the pits of the Vincentown Marl Co., which were near the Haines pit, showed an overburden of 6 feet of yellow and white sand and gravel resting on 15 to 20 feet of marl, gray above and black below.

At locality 88, on the opposite side of the creek from locality 87 , Dr. Kümmel observed, in September, 1917, several small openings that had been made within the preceding few years. There were piles of light ash-colored marl at an elevation of about 40 feet, and the pits showed 7 or 8 feet of sand and gravel overlying 3 to 4 feet of light yellowish-green marl blotched with clayey pellets. The pits were filled with water.

The pits on the H. J. Budd estate, at locality 89 , about $1 \frac{1}{2}$ miles east of Vincentown, were visited by Dr. Kümmel in September, 1917. No marl had been dug there for 20 years, and there were no exposures, but according to John W. Rose, who used to dig marl there, the pits formerly showed 3 to 6 feet of stripping succeeded by 3 feet of gray marl (locally with ironstone) overlying 12 to 18 feet of black marl. The bottom of the marl was not reached.

From the Ben Brown place, near Vincentown, W. C. Phalen collected a sample of marl from a previously dug pile and a check sample from a bed of greensand 5 or 6 feet thick. The first sample when analyzed in the laboratory of the United States Geological Survey was found to contain 3.74 per cent of potash and the second sample 4.22 per cent. ${ }^{31}$ A third sample from the Henry Butterworth place, between Pemberton and Vincentown, contained 4.28 per cent of potash. This sample represented 5 feet of greensand, which was overlain by 10 to 15 feet of clay and gravel.

LIME SAND.

According to data on file at the State Survey, lime sand was dug on Rancocas Creek near Vincentown at locality 90. In the early eighties the following section was exposed:

${ }^{81}$ Ashley, G. H., Notes on the greensand deposits of the United States: U. S. Geol. Survey Bull. 660, pp. $39,47,1918$. 
Section of Vincentown sand on Rancocas Creek, near Vincentown (locality 90).

Ft. in.

Brown sand and humus................................ 6

Yellow and white sand and marl..................... 2-4

Red sand........................................ 6

Lime sand, cemented in some places and full of Eschara...... 7-9

Limestone...................................... 10

24

In the spring of 1919 interest in the lime sand at Vincentown was revived, and some of the material was reported as being dug for agricultural lime.

\section{BIRMINGHAM AND PEMBERTON.}

\section{HOFFMAN PIT.}

William Hoffman owns a large pit at Birmingham (locality 91), from which he makes occasional shipments. (See Pl. IX, B.) The following section was exposed in January, 1919:

Section at William Hoffman's marl pit, at Birmingham (locality 91).

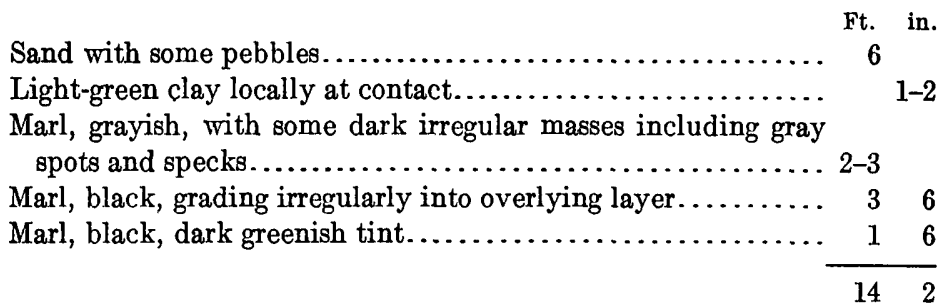

Mr. Hoffman states that the marl about 14 feet below the top is green and that he stops digging at that depth on account of water. A sample representing an average of 10 feet of greensand from this pit, taken by W. C. Phalen in 1917 and analyzed in the Survey laboratory, contained 7.07 per cent of potash $\left(\mathrm{K}_{2} \mathrm{O}\right) .{ }^{32}$

A well sunk for Mr. Harper at locality 92 , a short distance south of the Hoffman pit, shows the thickness of the marl and the amount of overburden that may be expected. Its record follows:

Record of Harper well, about 0.33 mile N. $24^{\circ} \mathrm{W}$. of Birmingham station (locality 92).

[Elevation, about 30 feet. S. J. Taylor, driller.]

\begin{tabular}{|c|c|c|c|}
\hline & $\begin{array}{c}\text { Thick- } \\
\text { ness. }\end{array}$ & Depth. & Formation. \\
\hline 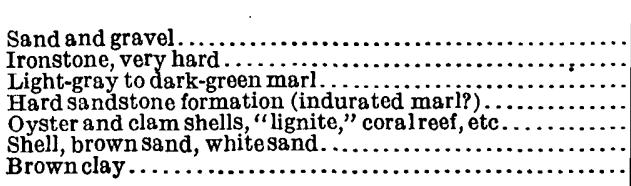 & $\begin{array}{r}\text { Feet. } \\
15 \\
2 \\
33 \\
10 \\
10 \\
20 \\
5\end{array}$ & $\begin{array}{r}\text { Feet. } \\
15 \\
17 \\
50 \\
60 \\
70 \\
90 \\
95\end{array}$ & $\begin{array}{l}\text { Quaternary. } \\
\text { Hornerstown and } \\
\text { Navesink. } \\
\text { Mount Laurel and } \\
\text { Wenonah. }\end{array}$ \\
\hline
\end{tabular}

Ashley, G. H., op. cit., p. 47. 
According to Mr. Taylor, the "lignite" of the above record is glauconite. The total thickness of the marl beds as there shown is 53 feet, and that of the overburden is 17 feet. The shell bed at the base of the Navesink, which lies at a depth of 60 feet in the well, is exposed in the bank of the creek above 12 feet of Mount Laurel sand at locality 93, about 1.2 miles north of Ewansville.

\section{PITS OF NORCROSS \& EDMUNDS CO.}

About half a mile east of Birmingham station the Norcross \& Edmunds Co. has operated a sand-washing plant for a number of years. The sand is taken from the company's property, which includes about half a square mile south of the creek and east of the station. So much sand has been removed that the overburden over much of that area has been greatly reduced. The property lies largely in the belt of Vincentown sand, but the creek has cut through into the marl about 0.2 mile east of the station, and near the western part of the property the Vincentown sand should not be very thick.

Men and tools were kindly supplied by the company for exploration, and three attempts were made to reach the marl in the vicinity of localities 94 and 95, but each attempt was unsuccessful because of the gravelly nature of the overburden and the nearness of water to the surface. The marl was not reached at depths of 3 or 4 feet.

In the southeastern part of the property two holes, Nos. 17 and 18, were sunk, respectively, at localities 96 and 97 in the Manasquan marl, and samples for analysis were taken. The character and potash content of the material are shown in the table below.

- Two attempts were made to sink a third hole by the creek at locality 98 , but these were abandoned at depths of 3 or 4 feet because of the gravelly nature of the overburden and the abundance of water.

Records of holes at sand pits of Norcross \& Edmunds Co.

Locality 96, hole 17.

[About 0.75 mile southeast of Birmingham station and about 375 feet northwest of culvert in road to South Pemberton. Elevation of present surface, about 50 feet. Analyst, E. T. Erickson.]

\begin{tabular}{|c|c|c|c|c|c|}
\hline & $\begin{array}{l}\text { Thick- } \\
\text { ness. }\end{array}$ & Depth. & $\begin{array}{c}\text { Field } \\
\text { No. of } \\
\text { sample. }\end{array}$ & $\mathrm{K}_{2} \mathrm{O}$ & Formation. \\
\hline $\begin{array}{l}\text { Gravel with pronounced iron-stained layers...... } \\
\text { Glauconite beds, thin alternating leafy layers of } \\
\text { drab fine sandy clay and greenish glauconitic }\end{array}$ & $\begin{array}{l}\text { Ft. in. } \\
3 \\
3 \\
3\end{array}$ & $\begin{array}{ccc}\text { Ft. in. } \\
3 \\
6 & 3\end{array}$ & $\mid \mathrm{M}-119 \mathrm{a}$ & Percent. & $\begin{array}{l}\text { Pleistocene. } \\
\text { Manasquan. }\end{array}$ \\
\hline $\begin{array}{l}\text { Glauconite beds, dark grayish green, clayey, } \\
\text { uniform texture, water bearing. }\end{array}$ & $\begin{array}{r}98 \\
.\end{array}$ & 1511 & $M-119$ & 3.61 & Do. \\
\hline
\end{tabular}


Locality 97, hole 18 .

[A bout 330 feet north of hole 17. Elevation of surface, about 50 feet. Analyst, E. T. Erickson.]

\begin{tabular}{|c|c|c|c|c|c|}
\hline & $\begin{array}{l}\text { Thick- } \\
\text { ness. }\end{array}$ & Depth. & $\begin{array}{l}\text { Field. } \\
\text { No. of } \\
\text { sample. }\end{array}$ & $\mathrm{K}_{2} \mathrm{O}$. & Formation. \\
\hline & Ft. in. & Ft. in. & & Per cent. & \\
\hline $\begin{array}{l}\text { Glauconite beds, thin alternating leafy layers of } \\
\text { drab fine sandy clay and greenish glauconitic } \\
\text { clay. Random sample taken at depth of } 9 \text { feet } \\
\text { considered representative of ontire bed. } \\
\text { Lower } 6 \text { to } 8 \text { inches a little darker and more } \\
\text { clayey. }\end{array}$ & $\begin{array}{ll} & 8 \\
14 & 4\end{array}$ & $15^{8}$ & $\mathrm{M}-120$ & 3.27 & $\begin{array}{l}\text { Pleistocen } \\
\text { Do. }\end{array}$ \\
\hline $\begin{array}{l}\text { Glauconite beds, clayey, dark greenish gray .... } \\
\text { Glauconite beds, light greenish gray with } \\
\text { grains of lime and lumps of vivianite. Lumps } \\
\text { are irregular in shape and rough in feel. The } \\
\text { bed has much clay and considerable glauconite } \\
\text { but appears quite limy with dark glauconite } \\
\text { streaks. At base a hard layer that could not } \\
\text { be penetrated with auger. Top of Vincen- } \\
\text { town(?). Water stands in hole about } 3 \text { feet } \\
\text { below surface. }\end{array}$ & $\begin{array}{ll}2 & 10 \\
1 & 8\end{array}$ & $\begin{array}{l}1710 \\
196\end{array}$ & $\begin{array}{l}\text { M-121 } \\
\text { M-122 }\end{array}$ & $\begin{array}{l}2.75 \\
1.83\end{array}$ & $\begin{array}{l}\text { Manasquan. } \\
\text { Do. }\end{array}$ \\
\hline
\end{tabular}

At locality 99, in the same general vicinity, a hole 10 to 15 feet square and perhaps 10 feet deep, now filled with water, had been recently dug in the Vincentown sand. No greensand appeared on the dump, but incoherent lime sand with some pieces of cemented limestone formed the bulk of the pile. Bryozoa were very numerous. Portions of the material were strongly cemented with iron oxide, and much vivianite was scattered over the dump in bluish radiating crystalline masses, in crusts, and in concretionary forms. Evidently the hole had missed the Manasquan marl and had not been dug deep enough to strike the Hornerstown.

From the vicinity of this hole westward and northward to the railroad the lime sand should be relatively near the surface and in sufficient quantity to be a commercial source in the event of any exploitation of greensand marl in the district. No analyses of this material are available, but from its appearance in the dump near the hole and in débris along some of the ditches cut by the company it seems probable that this lime sand will compare favorably in content of carbonate of lime with that from locality 83 , near Reeves station, which is utilized by the R. S. Ryan Co.

The Norcross \& Edmunds Co. also owns ground between Rancocas Creek and the road east of the tributary that enters the creek about 0.6 mile southeast of South Pemberton station. Through the courtesy of the company a hole, No. 19, was sunk at locality 100 , in the northwestern part of this property. There are numerous old marl pits in the vicinity, and some recent pits with equipment for digging. A site was selected near one of the recent pits where most of the overburden had been removed, and samples for analysis were collected, as shown in the following record. 
Record of hole 19, at locality 100.

[On property of Norcross \& Edmunds Co. about 4,200 feet S. $65^{\circ}$ E. from South Pemberton station, at group of old and recent marl pits. Elevation of present surface, about 36 feet. Analyst, E. T. Erickson.]

\begin{tabular}{|c|c|c|c|c|c|}
\hline & $\begin{array}{l}\text { Thick- } \\
\text { ness. }\end{array}$ & Depth. & $\begin{array}{l}\text { Field } \\
\text { No. of } \\
\text { sample. }\end{array}$ & $\mathrm{K}_{2} \mathrm{O}$. & Formation. \\
\hline Soil and gravel at level of former working... & Ft. in. & Ft. in. & & Per cent. & Ploictoron \\
\hline $\begin{array}{l}\text { Glauconite beds, dark grayish green, somewhat } \\
\text { clayey, fine textured, rather mealy. }\end{array}$ & 5 & 1 & $M-123$ & 4.29 & Manasquan. \\
\hline $\begin{array}{l}\text { Glauconite beds, lighter green, stiff, clayey; } \\
\text { contain considerable quartz in fine grains, } \\
\text { greasy feel and appearance on smooth surface. }\end{array}$ & 2 & 8 & & & \\
\hline $\begin{array}{l}\text { Glauconite beds similar to last but with more } \\
\text { quartz and somewhat mealy texture: irregu- } \\
\text { larstreaks oflighter and darker constituents. }\end{array}$ & 310 & 1110 & M-124 & 2.99 & Do. \\
\hline $\begin{array}{l}\text { Glauconite beds, darkergreen, larger percentage } \\
\text { of glauconite due to larger number of thin } \\
\text { beds of fine-textured glauconite. }\end{array}$ & 6 & 124 & & & \\
\hline $\begin{array}{l}\text { Glauconite beds, dark green, thin bedded, with } \\
\text { numerous layers of fine glauconitic material; } \\
\text { at base a stiff green clay. }\end{array}$ & 38 & 16 & $\mathrm{M}-125$ & 4.61 & Do. \\
\hline
\end{tabular}

The overburden at the hole was only 1 foot thick, but the top of the hole was about 3 feet below the level of the adjoining meadow to the northeast. The marl was not penetrated at the depth reached, 16 feet.

The analyses of the marl from holes 17 to 19 indicate that the portion of the Manasquan represented by them is distinctly inferior in potash content to the Hornerstown and Navesink marls. Determinations of the water-soluble potash of the samples from these holes showed either none or a mere trace.

Composite samples from these holes were tested for their content of lime $(\mathrm{CaO})$ and of phosphoric acid $\left(\mathrm{P}_{2} \mathrm{O}_{5}\right)$, with the results shown in the following table:

Potash, lime, and phosphate content of samples of Manasquan marl from holes on property of Norcross \& Edmunds Co., near Birmingham and South Pemberton (localities 96, 97 , and 100).

[Analyst, E. T. Erickson.]

\begin{tabular}{|c|c|c|c|c|c|}
\hline Field No. of sample. & $\begin{array}{l}\text { Thick- } \\
\text { ness. }\end{array}$ & $\mathrm{K}_{2} \mathrm{O}$. & Soluble $\mathrm{K}_{2} \mathrm{O}$. & $\mathrm{CaO}$. & $\mathrm{P}_{2} \mathrm{O}_{5}$ \\
\hline 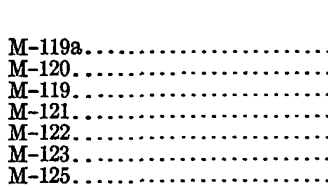 & $\begin{array}{rr}\text { Ft. } & \text { in. } \\
3 & 3 \\
14 & 4 \\
9 & 8 \\
2 & 10 \\
1 & 8 \\
5 & \\
3 & 8\end{array}$ & $\begin{array}{r}\text { Per cent. } \\
3.63 \\
3.27 \\
3.61 \\
2.75 \\
1.83 \\
4.29 \\
4.61\end{array}$ & 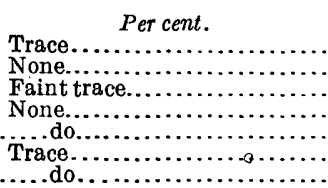 & $\left\{\begin{array}{r}\text { Per cent. } \\
1.53 \\
2.31 \\
3.86\end{array}\right.$ & $\begin{array}{r}\text { Percent. } \\
1.37 \\
3.58\end{array}$ \\
\hline
\end{tabular}

The lime and phosphate content of this marl, as indicated by the above analyses, is not high but is probably sufficient under favorable conditions to produce beneficial results in agriculture. The higher phosphate content of the middle group is probably due to the vivianite in sample 122. (See p. 87.) 
OTHER DATA.

At North Pemberton a well sunk near the station for Peter Cosgrove's creamery furnishes the following record:

Record of well at Peter Cosgrove's creamery, North Pemberton (locality 101).

[Elevation, about 35 feet. S. J. Taylor, driller.]

\begin{tabular}{|c|c|c|c|}
\hline & $\begin{array}{c}\text { Thick- } \\
\text { ness. }\end{array}$ & Depth. & Formation. \\
\hline 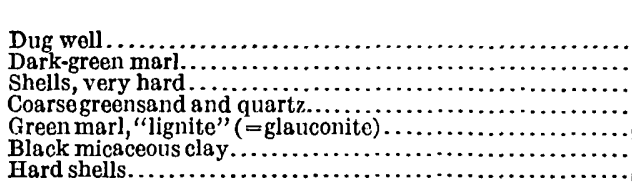 & $\begin{array}{r}\text { Fect. } \\
15 \\
65 \\
2 \\
6 \\
18 \\
20 \\
6\end{array}$ & $\begin{array}{r}\text { Feet. } \\
15 \\
80 \\
82 \\
88 \\
106 \\
126 \\
132\end{array}$ & $\left\{\begin{array}{l}\text { Manasquan and Vin- } \\
\text { centown(?). } \\
\text { Hornerstown a n d } \\
\text { Navesink (?). }\end{array}\right.$ \\
\hline 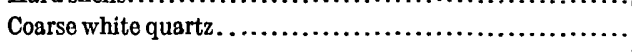 & 10 & 142 & $\begin{array}{l}\text { Mount Laurel and We } \\
\text { nonah. }\end{array}$ \\
\hline
\end{tabular}

The 65 feet of green marl in the upper part of this well is rather hard to interpret. The Vincentown locally contains much greensand and at some places, as at hole 16 (locality 63), might be called a greensand marl. The lime-sand phase does not appear to have been recognized here and may be absent, in which event the Manasquan and Vincentown might together form the "green marl." The two shell beds give rather definitely the position of the combined Hornerstown and Navesink beds, and, allowing for the dip, the lower shell bed is at about the right depth to correspond with its position at localities 92 and 93 . With this interpretation the combined Hornerstown and Navesink marls would be 52 feet thick.

At locality 102, near South Pemberton, are some old pits now overgrown. According to data on file at the State Survey, the following section was formerly exposed here:

Section exposed in the early eighties at marl pits near South Pemberton (locality 102).

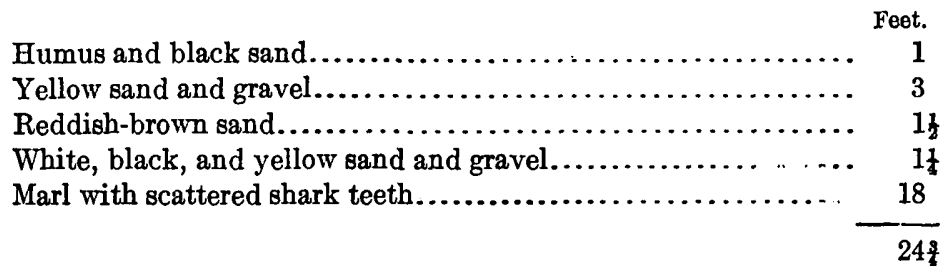

At locality 103, about 2 miles northeast of Pemberton, are some marl pits from which Ivins Horner made small shipments in 1914. This locality was visited by Dr. Kümmel in September, 1917, when he observed the following section:

Section at pits of Ivins Horner, 2 miles northeast of Pemberton (locality 103).

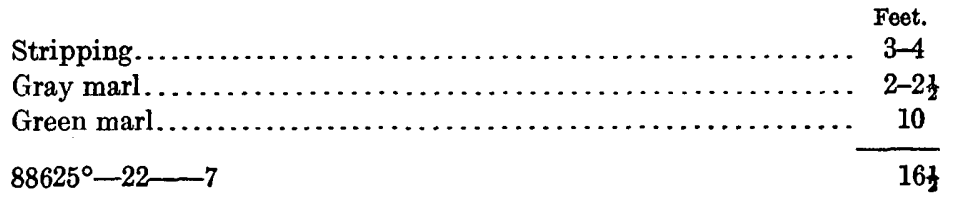


The marl pits occupy 2 or 3 acres dug over in rows. A large area can be opened to the south without much increase in stripping. The bottom of the marl was not reached, but the green marl is said to be 18 feet thick.

A sample of marl taken by W. C. Phalen from one of the piles was analyzed in the laboratory of the Geological Survey and found to contain 4.22 per cent of potash. A second sample taken from a bed where the greensand was 12 to 14 feet thick and the overburden 8 to 10 feet thick contained 4.74 per cent of potash. ${ }^{33}$

SUMMARY.

Near Birmingham there are several places in proximity to the railroad where Hornerstown and Navesink marl of suitable quality can be obtained in commercial quantities without too much overburden. Lime sand is also accessible near the railroad between Birmingham and Pemberton. The Manasquan marl near Pemberton is apparently 18 feet or more thick but so far as examined carries less potash than the Hornerstown and Navesink marls. The presence of small amounts of lime and phosphoric acid $\left(\mathrm{P}_{2} \mathrm{O}_{5}\right)$ probably explains its former popularity in agricultural use. The overburden is rather thick except along stream courses.

The available data do not warrant the formulation of specific tonnage estimates for the potash content of the areas described.

\section{OTHER AREAS.}

Although no further boring was done than that described, well records and fairly recent data bearing on the thickness and continuity of the marl are available for several other areas northeastward into Monmouth County. These are given below.

JOBSTOWN.

The well of Barclay White at Jobstown, locality not stated, shows that the marl continues into that district in probable commercial quality and thickness.

Record of well of Barclay White, Jobstown.

[W. C. Barr, driller.]

\begin{tabular}{|c|c|c|c|}
\hline - & $\begin{array}{l}\text { Thick- } \\
\text { ness. }\end{array}$ & Depth. & Formation. \\
\hline 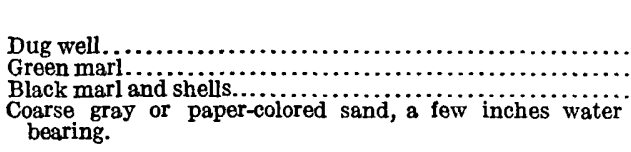 & $\begin{array}{r}\text { Feet. } \\
14 \\
10 \\
46\end{array}$ & $\begin{array}{r}\text { Feet. } \\
14 \\
24 \\
70\end{array}$ & $\left\{\begin{array}{l}{[\text { Hornerstown and Na. }} \\
\text { vesink]. } \\
\text { [Mount Laurel and } \\
\text { Wenonah.] }\end{array}\right.$ \\
\hline
\end{tabular}

${ }^{23}$ Ashley, G. H., op. cit., pp. 39, 47. 
A railroad traverses the marl belt southeast of Jobstown and affords suitable transportation facilities. The overburden in the higher lands along the railroad is probably excessive, but along the stream courses more favorable sites for exploitation may be expected. For example, a site near the stream and railroad crossings below Juliustown (Ellis station) would probably give a maximum of marl with a minimum of overburden. The lime sand occurs at Juliustown but is not well exposed.

\section{SYKESVILIE.}

In the vicinity of Sykesville the Hornerstown and Navesink marls become separated by the Redbank sand. A well sunk for the Newbold Black estate at locality 104(?), about 1 mile north of Sykesville, shows 15 feet of Navesink marl beneath 35 feet of gray sand.

At locality 105, about halfway between Sykesville and Georgetown, a well sunk for D. C. Kalback on timber land at an elevation of about 135 feet penetrated the base of the Navesink marl at a depth of about 81 feet. No specific record of this well is available, but material lying on the dump consisted chiefly of Navesink marl and Redbank sand with apparently a very good representation of the Navesink.

WRIGHTSTOWN.

At locality 106, about 0.9 mile north of Wrightstown station, a well sunk for Ellis (Robert?) Crowshaw furnishes the following record:

Record of well of Ellis Crowshaw near Wrightstown (locality 106).

[Elevation, about 160 feet. S. J. Taylor, driller.]

\begin{tabular}{|c|c|c|c|}
\hline & $\begin{array}{c}\text { Thick- } \\
\text { ness. }\end{array}$ & Depth. & Formation. \\
\hline 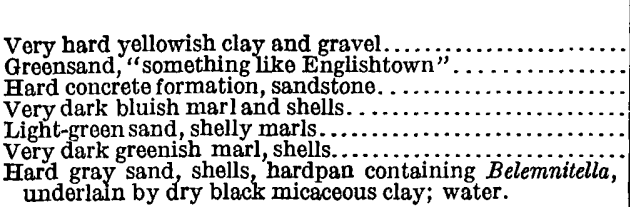 & $\begin{array}{r}\text { Feet. } \\
15 \\
5 \\
10 \\
20 \\
40 \\
20 \\
20\end{array}$ & $\begin{array}{r}\text { Feet. } \\
15 \\
20 \\
30 \\
50 \\
90 \\
110 \\
130\end{array}$ & $\begin{array}{l}\text { [Quaternary and Ter- } \\
\text { tiary.]. } \\
\text { [Vincentown?] } \\
\text { [Horners tow n and } \\
\text { Navesink.] } \\
\text { [Mount Laurel.] }\end{array}$ \\
\hline
\end{tabular}

The overburden here is 30 feet thick, of which the 10 feet of "hard concrete" may represent the limestone or lime-sand phase of the Vincentown. The marl appears to be 80 feet thick but may include beds assignable to the Redbank sand. The sand with Belemnitella is undoubtedly Mount Laurel.

On January 18, 1918, two wells were being drilled at an elevation of about 120 feet at locality 107, on the bank of the creek about three-eighths of a mile northwest of the station at Wrightstown. 
At that date one well was 130 feet deep and the other 320 feet. No definite record was kept, but Dr. Kümmel's inquiries elicited the following data:

Records of two wells about 0.38 mile N. $64^{\circ} \mathrm{W}$. of Wrightstown station (locality 107).

\begin{tabular}{|c|c|c|}
\hline . & $\begin{array}{l}\text { Thick- } \\
\text { ness. }\end{array}$ & Depth. \\
\hline 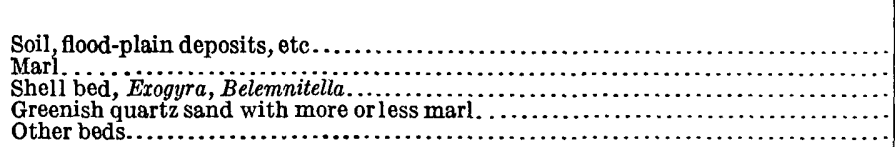 & $\begin{array}{r}\text { Feet. } \\
9 \\
101 \\
2 \\
13 \\
195\end{array}$ & $\begin{array}{r}\text { Feet. } \\
9 \\
110 \\
112 \\
125 \\
320\end{array}$ \\
\hline
\end{tabular}

Dr. Kümmel notes that the shell bed is undoubtedly the base of the Navesink marl. He thinks that part of what is reported as marl is Vincentown sand. The Kirkwood sand appears in the side slopes of the valley above the wells. From a contact of Navesink and Mount Laurel 3 miles away Dr. Kümmel estimates the dip here at 38 to 40 feet to the mile.

\section{JACOBSTOWN.}

At locality 108, along the road about 1.4 miles east of Jacobstown, the shell bed at the top of the Hornerstown is exposed in the stream bed north of the road. A considerable acreage of comparatively even ground with probably moderate overburden and with practically the full thickness of the Hornerstown marl is here available. Unfortunately the site is about $1 \frac{1}{2}$ miles from the nearest railroad shipping point, New Egypt.

At locality 109, about 1.1 miles farther northeast, on the road and county line, the shell bed at the top of the Hornerstown is exposed. Dr. Kümmel notes that the overlying Vincentown sand is a gray, more or less marly sand, more strongly marly in its lower 10 or 12 feet than in higher beds. At a pit nearby he observed the following section:

Section at pit near county line west of Crosswicks Creek, Monmouth County.

Vincentown sand

$$
\text { Feet. }
$$

Black greensand

Greensand with yellowish pebbles 1 inch in diameter, not 80 much clayey as limy in appearance........................ 6

Greensand, very black and massive, base not exposed.......... 6

\section{NEW EGYPT.}

The following record of a well drilled for the water company at New Egypt ${ }^{34}$ shows a probable great thickness of marl but does not differentiate the greensand from the Vincentown, in which it begins.

84 New Jersey Geol. Survey Ann. Rept. for 1909, p. 85. 
Record of well of water company at New Egypt.

[Elevation, 75 feet; Pfeiffer, d́riller.]

\begin{tabular}{|c|c|c|c|}
\hline & $\begin{array}{l}\text { Thick- } \\
\text { ness. }\end{array}$ & Depth. & Formation. \\
\hline 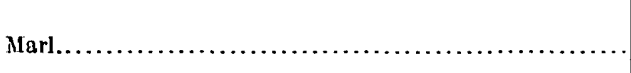 & $\begin{array}{r}\text { Feet. } \\
112\end{array}$ & $\begin{array}{r}\text { Feet. } \\
112\end{array}$ & [Vincentown to Nave- \\
\hline 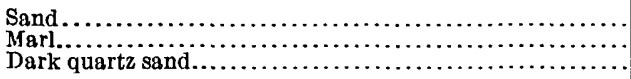 & $\begin{array}{r}8 \\
98 \\
20\end{array}$ & $\begin{array}{l}120 \\
218 \\
238\end{array}$ & $\begin{array}{l}\text { [Mount Laurel to Mar- } \\
\text { shalltown?] } \\
\text { [Englishtown.] }\end{array}$ \\
\hline
\end{tabular}

The base of the Navesink is probably at the depth of 112 feet. Its thickness combined with that of the Hornerstown doubtless exceeds 50 feet.

About 1 mile south of New Egypt the Manasquan marl forms an irregular area in which a number of old marl pits are located. These are mostly inactive and overgrown, but at some of them marl has been dug as late as 1915. In October, 1913, Dr. Twitchell ${ }^{35}$ observed the following section at the Huggins pit:

Section at Huggins marl pit, about $1 \frac{1}{2}$ miles south of New Egypt.

Soil, gray sandy, with a few pebbles.................... ${ }^{2}$

Marl, olive green, apparently reworked, yellow spots and streaks... 4

Marl, dark olive green to greenish black, pale-yellow specks and

concretions........................................ 4

Some marl was dug here in 1912-13. The surface where dug looks like fine light-gray ashes.

HORNERSTOWN.

At locality 111, about 0.75 mile southwest of Hornerstown, there is a large marl pit, formerly worked on an extensive scale and connected with the railroad by a spur track. This pit was visited in 1917 by Dr. Kümmel, from whose field notes the following observations are taken:

The old marl pit is now grown up with sizeable trees. The old switch is now torn up, but the graded cut is still available. The marl is fairly well shown on the sides. On the south side it lies within 1 or 2 feet of the surface and is covered with sand, with a line of pebbles at the base. If the marl extends to the bottom of the pit its thickness must be in excess of 20 feet. The excavation can be extended southward for several rods and northward an equal distance without increase of thickness of cover. East of the railroad is a broad field of 20 to 40 acres, or perhaps more, in which the marl probably lies very near the surface. This is one of the best pits. It is now owned by the Richard Miers estate. Some marl has been dug at Hornerstown within recent years, but none has been sold.

Along Crosswicks Creek and in some of its branches the marl is exposed here and there within 1 or 2 miles of Hornerstown. At

85 Data on fle at New Jersey Geological Survey. 
locality 112 , in a tributary opposite Lahaway Creek, the basal bed of the Navesink is exposed on both sides of the creek east of the road, and characteristic fossils, including Belemnitella, may be found in it.

A well sunk for Charles Higgins near and southwest of the mill pond at Hornerstown furnishes the following record, which is given both as reported and as here interpreted.

Record of well of Charles Higgins, southwest of mill pond at Hornerstown (locality 113).

[Elevation, 20 feet (above pond?); F. R. Hope. driller.]

As reported.

As above interpreted the well shows 22 feet of Hornerstown marl beneath 12 feet of overburden. The base of the Navesink is probably at a depth of 73 feet. The zone between the Hornerstown and Navesink, as exposed in the ravine at locality 114, is black, glauconitic, and micaceous and might be called a black marl.

\section{CREAM RIDGE AND DAVIS.}

A railroad traverses the Navesink marl between Cream Ridge and Davis and could supply transportation for marl or marl products, in case of any commercial development. A pit at locality 115, about 0.45 mile east of Davis, shows the following section:

Section at marl pit 0.45 mile east of Davis (locality 115).

Fine reddish and yellowish sand. Feet.

Black micaceous sand with some clay pellets and greensand; scattered large shells (Gryphaea)........................ 10-11

There is a distinct iron-bearing zone between the two beds of sand, forming a dark line on the weathered face of the pit. This is probably the contact between the Redbank sand and the underlying Navesink marl, the base of which is not exposed.

\section{MARLBORO.}

The Navesink marl was dug in large quantities many years ago at Marlboro and Holmdel and along branches of Hop Brook east of Marlboro. There are some very large pits in this vicinity, but most 
of them are now inactive and more or less overgrown. From time to time small amounts of marl are dug for local use.

The United States Department of Agriculture has recently arranged for a shipment of three carloads of greensand marl from Marlboro to Florence, S. C., for experimental use on lands deficient in potash. (See pp. 113-115.)

The following rather recent analyses of Navesink marl from the vicinity of Marlboro give a good idea of the phosphoric acid and potash content of what may perhaps be called random or run of mine samples:

'Analyses of samples of Navesink marl from Marlboro and vicinity. ${ }^{a}$

[Collected by C. C. Engle, representing the New Jersey Geological Survey.]

\begin{tabular}{|c|c|c|c|}
\hline No. & Location. & $\mathrm{P}_{2} \mathrm{O}_{6}$ & $\mathrm{~K}_{2} \mathrm{O}$ \\
\hline \multirow[t]{2}{*}{$\begin{array}{r}1 \\
1 \\
3 \\
4 \\
5 \\
6 \\
7 \\
8 \\
9 \\
10\end{array}$} & \multirow[t]{2}{*}{ 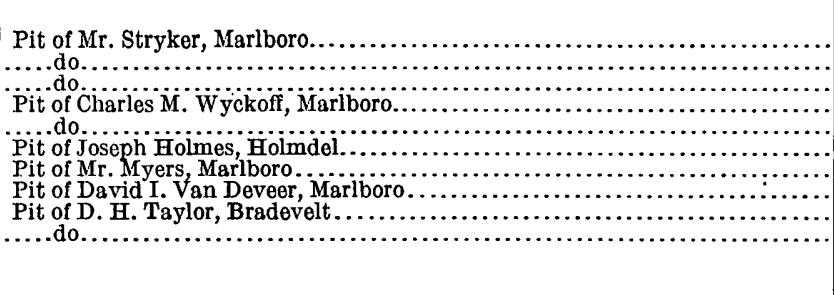 } & \begin{tabular}{r|} 
Per cent. \\
0.82 \\
1.20 \\
1.05 \\
1.10 \\
.94 \\
.73 \\
1.21 \\
.64 \\
.99 \\
.39
\end{tabular} & $\begin{array}{r}\text { Per cent. } \\
5.06 \\
5.44 \\
5.70 \\
6.50 \\
6.28 \\
6.05 \\
4.24 \\
5.05 \\
4.64 \\
6.16\end{array}$ \\
\hline & & .907 & 5.512 \\
\hline
\end{tabular}

a Blair, A. W., The agricultural value of greensand marl: New Jersey Agr. Exper. Sta. Circ. 61, p. 12, 1916.

At the John Van Kirk place, at Marlboro, where 10 feet of greensand containing shells is overlain by 3 to 5 feet of gravel, W. C. Phalen collected a sample which was analyzed at the laboratory of the United States Geological Survey and found to contain 4.45 per cent of potash..$^{36}$

The average potash content of the Navesink marl dug near Marlboro, if judged by the analyses in the above table, is 1.09 per cent lower than the average obtained from the borings at holes 1 to 16 , as described above. (See also p. 104.) The phosphoric acid content of nearly 1 per cent would give the marl additional agricultural value.

Marlboro and Bradevelt are on the railroad, and the country in their vicinity is sufficiently level to permit exploitation of considerable areas. The Marlboro district is thus the rnost favorably situated of the Navesink localities for commercial development.

\section{FREEHOLD.}

The Hornerstown marl comes to the surface over extensive areas in the vicinity of Freehold. Marl was formerly dug here but on a less extensive scale than at Marlboro, and there has been little recent digging. Recent analyses, showing the phosphoric acid and potash

${ }^{86}$ Ashley, G. H., Notes on the greensand deposits of the United States: U. S. Geol. Survey Bull. 660 , pp. 39,47 . 
content of random or run of mine samples from Freehold, are given in the following table:

Analyses of samples of Hornerstown marl from pit of $J$. W. Dobbins, Freehold.a

[Collected by C. C. Engle, representing the New Jersey Geological Survey.]

\begin{tabular}{|c|c|c|c|}
\hline - & No. & $\mathrm{P}_{2} \mathrm{O}_{5}$ & $\mathrm{~K}_{2} \mathrm{O}$ \\
\hline $\begin{array}{l}18 \ldots \ldots \\
19 \ldots \ldots \\
20 \ldots \ldots\end{array}$ & & $\begin{array}{r}\text { Per cent. } \\
0.81 \\
1.40 \\
.67\end{array}$ & $\begin{array}{r}\text { Per cent. } \\
6.05 \\
5.04 \\
5.12\end{array}$ \\
\hline A verage. & & .96 & 5.40 \\
\hline
\end{tabular}

a Blair, A. W., op. cit.

The average phosphoric acid content of the three samples from Freehold is slightly higher than that of the ten samples from Marlboro, but the potash content is a little lower. These differences might disappear if a larger number of analyses were available.

Freehold, because of its railroad facilities, is one of the most favorable localities in Monmouth County for the commercial development of the Hornerstown marl.

\section{EATONTOWN.}

At Eatontown and about 3 miles to the east, at Branchport, the Hornerstown marl is crossed by railroads, and at Branchport it is on tidewater at Pleasure Bay, which cuts diagonally across the marl bed. Parker Creek, a branch of Shrewsbury River, also tidewater, lies along the northwest border of the Hornerstown bed.

At locality 116, about 0.3 mile north of Eatontown, according to field notes of Dr. Kümmel, the Hornerstown marl beneath a thin cap of gravel reaches an elevation of 25 to 28 feet in the road cut at the top of the hill and extends down 10 feet, to the level of the flood plain of the creek to the north, or even lower. Thus the maximum thickness of the marl near Eatontown is probably as much as 20 feet and may be more.

At locality 117, half a mile south of Shrewsbury, the road cut, according to Dr. Kümmel's notes, shows 6 to 7 feet of marl from 25 to 32 feet above sea level. The marl passes downward into a more or less indurated marly sand (Tinton) revealed only by boring. Thus the marl outcrop should be extended somewhat farther north than is shown on the map. The slope of the surface southward to the creek corresponds very closely with the dip of the marl bed.

The Eastern Potash Corporation has acquired of Charles McCue the Crystal Brook farm, about 75 acres, including land between the road and the railroad and on both sides of the brook half a mile north of Eatontown. It also has provisional options on land farther east. The following analyses of samples collected from these properties have been kindly supplied by Mr. T. C. Meadows, manager of the corporation: 
Analyses of samples of greensand from vicinity of Eatontown.

[Analysts, Stilwell \& Gladding, New York.]

\begin{tabular}{|c|c|c|}
\hline No. & & $\begin{array}{l}\text { Total } \\
\text { potash } \\
\left(\mathrm{K}_{2} \mathrm{O}\right)\end{array}$ \\
\hline 217490 & $\begin{array}{l}\text { Sample from military pig pen from Monmouth Park, received from the American Pot- } \\
\text { ash Corporation a July } 30 \text {, } 1918 \text {. }\end{array}$ & \multirow{3}{*}{$\begin{array}{r}\text { Percent. } \\
8.75 \\
8.68 \\
8.19\end{array}$} \\
\hline 217489 & $\begin{array}{l}\text { Greensand "from top of knoll beside nursery, ; received from the American Potashi Cor- } \\
\text { poration July } 30 \text {. }\end{array}$ & \\
\hline 218045 & $\begin{array}{l}\text { Greensand marked "No. } 7-61 \text { overburden, } 14 \text { feet blue and green marl," received from } \\
\text { the American Potash Corporation, Aug. } 15,1918 \text {. On samplo dried at } 212^{\circ} \mathrm{F} . . . . . .\end{array}$ & \\
\hline
\end{tabular}

a The Eastern Potash Corporation has taken over the rights and patents of the American Potash Corporation, in so far as they relate to potash extraction from greensand.

In view of the results obtained from samples already cited in other parts of the marl belt these results seem high.

A sample of fresh marl, collected at a depth of 1 foot at locality 118, on the property of the Eastern Potash Corporation, was analyzed at the laboratory of the United States Geological Survey. It contained 7.09 per cent of potash (total $\mathrm{K}_{2} \mathrm{O}$ ), including a trace of soluble potash. This analysis, which may serve as a check upon the others, shows that the Hornerstown marl at Eatontown compares favorably with the better-grade marls elsewhere in the marl belt, but it shows also that the Eatontown material is perhaps not so conspicuously high in total potash as the analyses in the table would indicate.

According to field notes of Dr. Kümmel, the thickness of the Hornerstown marl at Crawford Hill (locality 119), about $8 \frac{1}{2}$ miles northwest of Eatontown is about 25 feet.

\section{FARMINGDALE.}

The Manasquan marl was formerly dug in considerable quantity in the vicinity of Farmingdale, in Monmouth County, and enjoyed a high reputation as an agricultural marl. The pit nearly half a mile northeast of the town (locality 120), now owned by D. Mahoney, is doubtless the largest. It has long been inactive and largely filled with water. (See Pl. IX, C.) The following section was measured by Dr. Kümmel ${ }^{37}$ at the north end of the pit:

Section at D. Mahoney's marl pit, Farmingdale.

Feet.

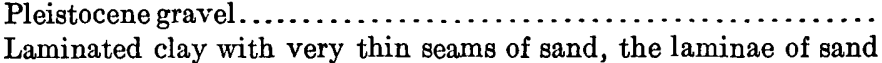
more numerous and thicker in upper portion; the upper part of the exposure weathered to a yellow color; the lower 8 feet nearly black or very dark chocolate-colored; no glauconite. Kirkwood

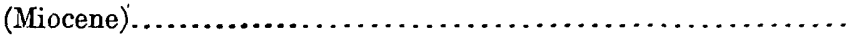

Greensand marl composed of glauconite and very fine quartz sand; when wet material is plastic and coherent; only upper portion

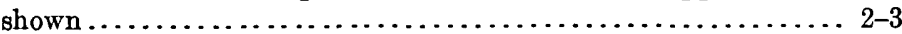


The overburden at the north side of the pit is now 18 feet or more. It probably increases in that direction, but toward the northwest, southwest, and south probably considerable extensions of the pit could be made without finding much increase of overburden.

The Squankum pits, about 3 miles south of Farmingdale, which formerly produced much marl, are now flooded.

At the pits of James H. Johnson, about three-quarters of a mile southwest of Farmingdale (locality 121), Dr. Twitchell ${ }^{38}$ in 1912 observed the following section:

Section at marl pits of $J$. H. Johnson, near Farmingdale.

Feet.

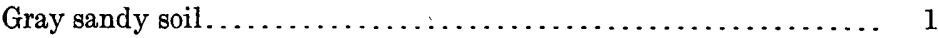

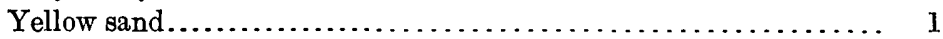

Yellow sand and abundant gravel....................... 1

Chocolate-colored clay, laminated ........................ 2-3

Light bluish green to olive-green $\operatorname{marl} . \ldots \ldots \ldots \ldots \ldots \ldots \ldots \ldots \ldots . \quad 1$

7

The marl is light greenish gray when dry, piles of it resembling piles of ashes. In $1884 \mathrm{~N}$. L. Britton visited these pits and noted the following section: ${ }^{30}$

Britton's section at Johnson marl pits in 1884.

Feet.

Brown sand and humus.................................. 2

Yellow drift........................................ 3

Marl ......................................... 15-17

22

The excavations are in the ash and blue marl layers of the upper marl bed.

Small thicknesses of marl are exposed along the water's edge at several places along the river in the vicinity of the Johnson pits.

Several relatively recent analyses of marl samples from Farmingdale show something of the phosphoric acid and potash content of the Manasquan marl in that vicinity.

\section{Analyses of samples of marl from Farmingdale. ${ }^{a}$}

[Collected by C. C. Engle, representing the New Jersey Geological Survey.]

\begin{tabular}{|c|c|c|c|}
\hline No. & Locality. & $\mathrm{P}_{2} \mathrm{O}_{3}$ & $\mathrm{~K}_{2} \mathrm{O}$ \\
\hline $\begin{array}{l}11 \\
12 \\
13 \\
14 \\
15 \\
16 \\
17\end{array}$ & 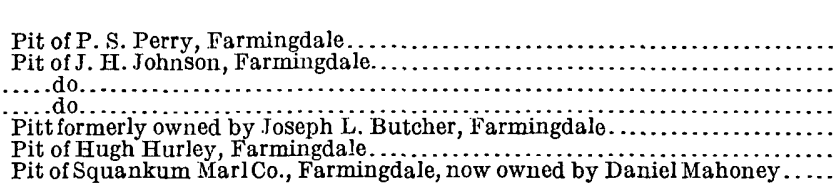 & $\begin{array}{r}\text { Per cent. } \\
1.12 \\
1.32 \\
.70 \\
1.81 \\
.17 \\
.68 \\
2.31\end{array}$ & $\begin{array}{r}\text { Per cent. } \\
2.76 \\
3.40 \\
2.13 \\
3.72 \\
1.85 \\
1.94 \\
4.24\end{array}$ \\
\hline & Average. & 1.16 & 2.86 \\
\hline
\end{tabular}

a Blair, A. W., The agricultural value of greensand marl: New Jersey Agr. Exper. Sta. Circ. 61, p. $12,1916$.

${ }^{38}$ Twitchell, M. W., field notes on file at New Jersey Department of Conservition and Development.

89 Twitchell, M. W., idem. 
A sample collected by W. C. Phalen from Daniel Mahoney's property was analyzed in the laboratory of the United States Geological Survey and found to contain 3.54 per cent of potash. ${ }^{40}$

The thicknesses represented by these samples are unknown, but in so far as the samples are representative of the Manasquan marl they show a lower potash content than that of either the Navesink or the Hornerstown and thus confirm the similar findings at holes 17 to 19 , localities 96, 97, and 100, near Pemberton. The phosphoric acid content of the Manasquan marl, as judged by these samples, is noteworthy and is probably a considerable factor in its former agricultural popularity.

The Shark River marl (Eocene) is also exposed near Farmingdale at locality 122, along Manasquan River about 1 mile below the Johnson pits, above described. In 1912 Dr. Twitchell ${ }^{41}$ measured the following section at this place:

Geologic section on Manasquan River about 1 mile south of station at Farmingdale.

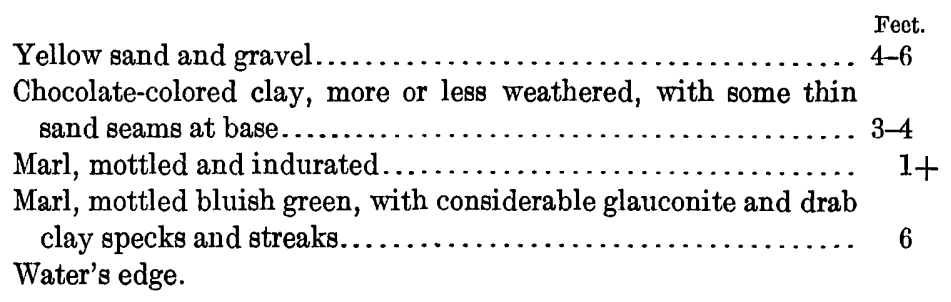

17

The marl is fossiliferous close to and in the indurated portion. A similar exposure with less marl occurs at locality 123, about 0.1 mile farther up the river.

\section{POPLAR AND ELBERON.}

Along the creek about 0.75 mile south of Poplar, in Monmouth County, the old marl pits at locality 124 and vicinity are much overgrown, but on the north side of the creek the upper part of the Manasquan marl is exposed with the base of the Kirkwood. Dr. Kümmel visited this locality in 1917 but found no fresh openings.

At locality 125, about 0.8 mile southwest of the station at Elberon, in Monmouth County, Dr. Twitchell found, in 1912, an exposure of Shark River marl in a gully near the barn of the Deal Golf and Country Club. Beneath 4 feet of yellow sand and gravel he found 8 feet of fairly uniform mottled grayish-green marl with clay specks. There were old marl pits in the vicinity.

The main body of Shark River marl lies about 0.6 mile south of Elberon and occupies an area about $1 \frac{1}{2}$ miles long at the coast and

${ }^{40}$ Ashley, G. H., op. crt., pp. 39, 47.

« Twitchell, M. W., field notes on file at New Jersey Department of Conservation and Development. 
stretches back 1 to 2 miles from the shore. This area is now largely a residential district with pleasure grounds.

Two wells drilled at South Elberon near the railroad and about half a mile north of the Deal Beach station furnish the following combined record, which is slightly modified from Kümmel's account. ${ }^{42}$

Combined record of two wells at South Elberon (locality 126).

\begin{tabular}{|c|c|c|c|}
\hline & $\begin{array}{l}\text { Thick- } \\
\text { ness. }\end{array}$ & Depth. & Formation. \\
\hline 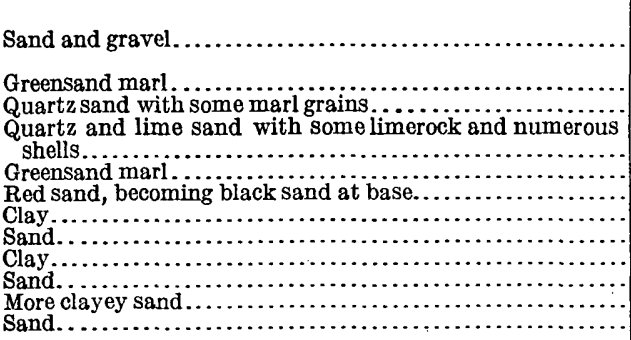 & $\begin{array}{r}\text { Feet. } \\
12 \\
78 \\
40 \\
\\
70 \\
100 \\
59 \\
19 \\
31 \\
35 \\
21 \\
7 \\
33\end{array}$ & $\begin{array}{r}\text { Feet. } \\
12 \\
\\
90 \\
130 \\
\\
200 \\
300 \\
359 \\
378 \\
409 \\
444 \\
465 \\
472 \\
505\end{array}$ & $\begin{array}{l}\text { Cape May (Pleisto- } \\
\text { cene). } \\
\text { Manasquan. } \\
\text { Vincentown. } \\
\text { Do. } \\
\text { (Hornerstown?) } \\
\text { Redbank (?). } \\
\text { Navesink (?). } \\
\text { Wenonah (?). } \\
\text { Marshalltown (?). } \\
\text { (Englishtown?) } \\
\quad \text { Do. } \\
\text { Do. }\end{array}$ \\
\hline
\end{tabular}

The Manasquan marl is unusually thick (78 feet) and has an overburden of 12 feet. The lime sand also is well developed but deeply buried. The top of the Hornerstown lies at a depth of 200 feet and is 100 feet thick. There is some uncertainty about the correlation of the beds in the lower part of the section.

\section{ASBURY PARK.}

The records of several wells at Asbury Park have been studied by Woolman ${ }^{43}$ and compiled into a single record, which, in simpler form, is presented below:

Record of well at Asbury Park.

[Elevation, 10 feet. Uriah White, driller.]

\begin{tabular}{|c|c|c|c|}
\hline & $\begin{array}{c}\text { Thick- } \\
\text { ness. }\end{array}$ & Depth. & Formation. \\
\hline 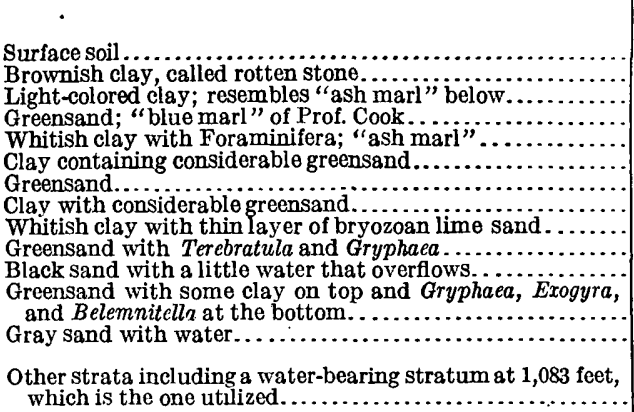 & $\begin{array}{r}\text { Feet. } \\
16 \\
64 \\
13 \\
7 \\
40 \\
20 \\
20 \\
20 \\
40 \\
40 \\
7 \\
93 \\
50 \\
\\
891\end{array}$ & $\begin{array}{r}\text { Feet. } \\
16 \\
80 \\
93 \\
100 \\
140 \\
160 \\
180 \\
200 \\
240 \\
280 \\
287 \\
\\
380 \\
430 \\
\end{array}$ & $\left\{\begin{array}{l}\text { Recent. } \\
\text { [Kirkwood?] } \\
\text { [Shark River?] } \\
\text { [Sanasquan.] } \\
\text { [Mincentown.] } \\
\text { [Wornerstown.] } \\
\text { [Hedbank. } \\
\text { [Navesink.] } \\
\text { [Mount Laurel } \\
\text { Wenonah.] }\end{array}\right.$ \\
\hline
\end{tabular}

42 Kümmel, H. B., New Jersey Geol. Survey Ann. Rept. for 1904, p. 269, 1905.

${ }^{43}$ Woolman, Lewis, New Jersey Geol. Survey Ann. Rept. for 1895, pp. 72-73, 1896 
Here the Hornerstown marl is 40 feet thick and lies 240 feet below the surface. The Navesink marl is reported as 93 feet thick. The Vincentown contains only a thin layer of lime sand. The greensand member of the Manasquan is 20 feet thick, though the formation as a whole is 100 feet thick.

\section{OCEAN GROVE.}

A well at Ocean Grove shows the marl beds at somewhat greater depths and with more variations in thickness. The following record is simplified from that of Woolman. ${ }^{44}$

Record of well at Ocean Grove.

[Elevation, 20 feet. Uriah White, driller.]

\begin{tabular}{|c|c|c|c|}
\hline & $\begin{array}{c}\text { Thick- } \\
\text { ness. }\end{array}$ & Depth. & Formation \\
\hline 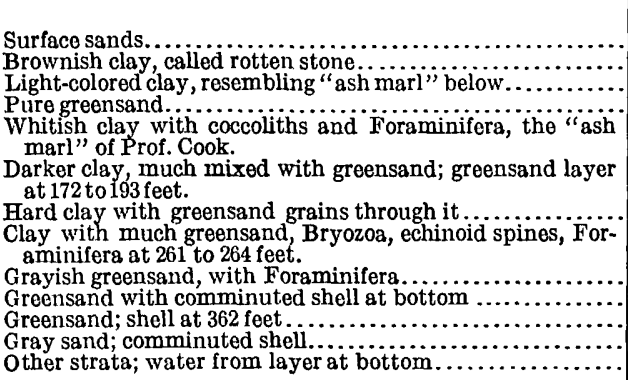 & $\begin{array}{r}\text { Feet. } \\
20 \\
55 \\
30 \\
8 \\
47 \\
48 \\
4 \\
19 \\
37 \\
20 \\
16 \\
81 \\
76 \\
677\end{array}$ & $\begin{array}{r}\text { Feet. } \\
20 \\
75 \\
105 \\
113 \\
160 \\
\\
208 \\
\\
227 \\
264 \\
\\
284 \\
300 \\
381 \\
457 \\
1,134\end{array}$ & $\left\{\begin{array}{l}\text { Recent. } \\
\text { [Kirkwood?] } \\
\text { [Shark River?] } \\
{[\text { Manasquan.] }} \\
\text { [Vincentown.] } \\
{[\text { Hornerstown.] }} \\
\text { Redbank. } \\
{[\text { Navesink.] }} \\
{[\text { Mount Laurel }} \\
\text { Wenonah.] }\end{array}\right.$ \\
\hline
\end{tabular}

Here the top of the Hornerstown is at a depth of 264 feet. The Hornerstown and Navesink together represent a thickness of 101 feet but are separated by a greensand layer, presumably less glauconitic, 16 feet thick.

SEA GIRT.

The New Jersey coast cuts obliquely across the strike of the Coastal Plain strata in this part of the State, so that a well at Sea Girt, which is 6 or 7 miles nearly south of Asbury Park, strikes the marl beds farther down their dip than wells at either Asbury Park or Ocean Grove. A well at the Beach House furnishes the following record, which is simplified from Woolman's account. ${ }^{45}$

44 Woolman, Lewis, op. cit., p. 74.

45 Idem, p. 76. 
Record of well at Beach House, Séa Girt.

[Elevation, 11 feet. Uriah White, driller.]

\begin{tabular}{|c|c|c|c|}
\hline & $\begin{array}{c}\text { Thick- } \\
\text { ness. }\end{array}$ & Depth. & Formation. \\
\hline 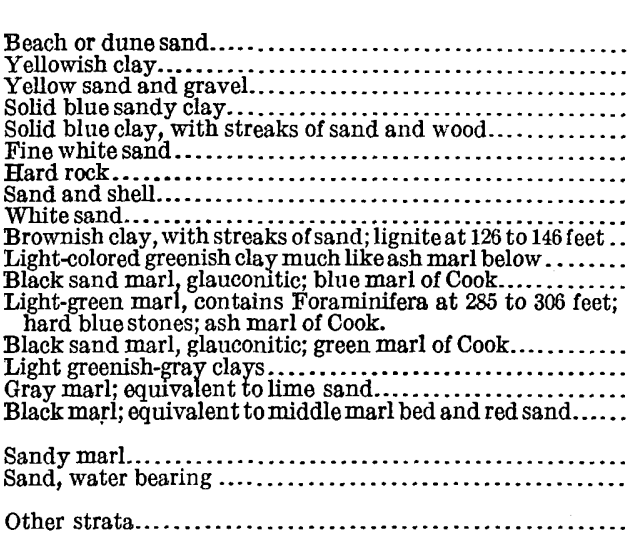 & $\begin{array}{r}\text { Feet. } \\
10 \\
2 \\
13 \\
25 \\
10 \\
6 \\
4 \\
9 \\
47 \\
109 \\
25 \\
15 \\
70 \\
15 \\
40 \\
50 \\
39 \\
\\
81 \\
50 \\
135\end{array}$ & $\begin{array}{r}\text { Feet. } \\
10 \\
12 \\
25 \\
50 \\
60 \\
66 \\
70 \\
79 \\
126 \\
235 \\
260 \\
275 \\
345 \\
\\
360 \\
400 \\
450 \\
489 \\
\\
570 \\
620\end{array}$ & 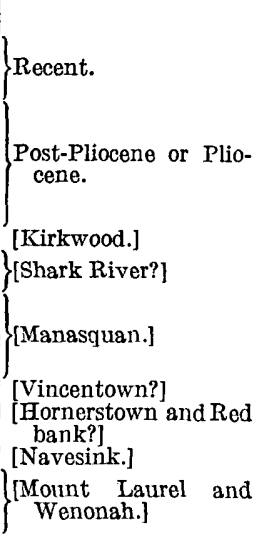 \\
\hline
\end{tabular}

Here the top of the Hornerstown is apparently 450 feet below the surface.

\section{LAKEWOOD.}

From specimens and information regarding two wells at Lakewood Woolman ${ }^{46}$ compiled a record which is presented below in simpler form.

\section{Record of two wells at Lakewood.}

[Elevation, 50 feet; depths, 475 and 612 feet. Uriah White, driller.]

\begin{tabular}{|c|c|c|}
\hline & $\begin{array}{l}\text { Depth of } \\
\text { samples. }\end{array}$ & Formation. \\
\hline 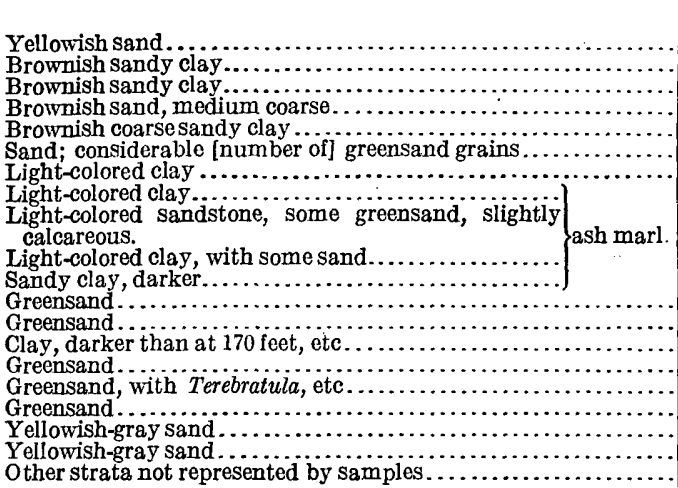 & \begin{tabular}{r|} 
Feet. \\
43 \\
50 \\
75 \\
112 \\
135 \\
168 \\
170 \\
200 \\
240 \\
\\
245 \\
270 \\
280 \\
350 \\
355 \\
360 \\
370 \\
390 \\
450 \\
460 \\
$460-612$
\end{tabular} & 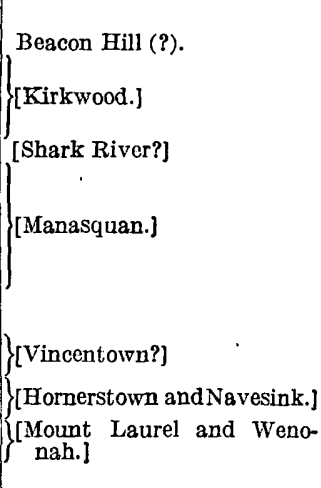 \\
\hline
\end{tabular}

In view of the great thickness of the Vincentown reported in the $\log$ of the well at Atlantic City, it seems probable that some of the

16 Woolman, Lewis, New Jersey Geol. Survey Ann. Rept. for 1896, p. 148, 1897. 
greensand referred above to the Manasquan, which here seems unduly thick, should be ascribed to the Vincentown. The top of the Hornerstown is here at a depth of 370 feet.

\section{ATLANTIC CITY.}

A deep well at Atlantic City shows the depth of the marl beds at the easternmost limit of the Coastal Plain, at a point about 45 miles from the outcrop in the direction of the dip. The well was drilled about 1,000 feet out on Young's ocean pier at the foot of Tennessee Avenue. The record as compiled by Woolman ${ }^{47}$ is presented below in simpler form.

Record of well at Young's Pier, Atlantic City.

[Elevation of pier, 20 feet. Uriah White, driller.]

\begin{tabular}{|c|c|c|c|}
\hline & $\begin{array}{l}\text { Thick- } \\
\text { ness. }\end{array}$ & Depth. & Age or formation. \\
\hline Floor of pier to mean tide level ........ & Feet. & Feet. & \\
\hline 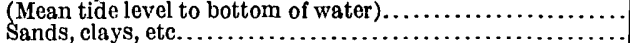 & $\begin{array}{r}(15) \\
237\end{array}$ & $\begin{array}{r}35 \\
272\end{array}$ & Post-Miocene. \\
\hline $\begin{array}{l}\text { Sands, clays, diatom beds, gravel, greensand, etc., including } \\
\text { at } 780-860 \text { feet the Atlantic City } 800 \text {-foot water horizon. }\end{array}$ & $943 \pm$ & 1,215 & Tentatively Miocene. \\
\hline $\begin{array}{l}\text { Groensand marl } \\
\text { Very hard, tough light and dark slate or ash-colored clays }\end{array}$ & $\begin{array}{r}25 \\
200\end{array}$ & $\begin{array}{l}1,240 \\
1,440\end{array}$ & 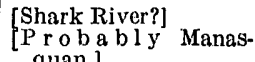 \\
\hline $\begin{array}{l}\text { Yellowish calcarcous rock, soft or hard; two-thirds consists } \\
\text { of nearly equa l mixture of greensand and quartz; the } \\
\text { other third is carbonate of lime, the cementing material; } \\
\text { contains Foraminifera. }\end{array}$ & 460 & 1,900 & 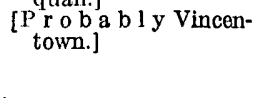 \\
\hline Glauconitic greensand marl $\ldots \ldots \ldots \ldots \ldots \ldots \ldots \ldots \ldots \ldots \ldots$ & 40 & 1,940 & \\
\hline $\begin{array}{l}\text { Clay mixed with a little greensand } \ldots \ldots \ldots \ldots \ldots \ldots \ldots \\
\text { Indurated ash-colored clay, "hard almost as rock" } \ldots \ldots \ldots \ldots \\
\text { Glauconitic greensand marl similar to that at } 1,900 \text { to } 1,940\end{array}$ & $\begin{array}{l}70 \\
60 \\
80\end{array}$ & $\begin{array}{l}2,010 \\
2,070 \\
2,150\end{array}$ & $\left\{\left[\begin{array}{c}\text { Probably Horners- } \\
\text { town and Navesink. }]\end{array}\right.\right.$ \\
\hline $\begin{array}{l}\text { feet. } \\
\text { Black or dark micaceous sandy clays... }\end{array}$ & 156 & 2,306 & $\begin{array}{l}\text { [Mount Laurel and } \\
\text { Wenonah?] }\end{array}$ \\
\hline
\end{tabular}

The top of the Hornerstown marl is here apparently at a depth of 1,900 feet. Two beds of greensand, 40 and 80 feet thick, are separated by 130 feet of clay. The thickness of the overlying Vincentown sand, 460 feet, is the maximum recorded thickness for that formation, which is not, however, so calcareous here as in Salem and Burlington counties.

\section{SUMMARY OF FIELD DATA AND ESTIMATES.}

At Sewell three greensand beds of commercial quality and thickness have been recognized, which with some variations are generally distinguishable throughout the region where borings were made. These are gray or bank marl, green marl, and chocolate marl. The following table gives the range in thickness and quality of these three beds at the five localities explored. 
Thickness and potash content of commercial beds of greensand at five localities in Salem, Gloucester, Camden, and Burlington counties.

\begin{tabular}{|c|c|c|c|c|c|c|}
\hline \multirow{2}{*}{ Locality. } & \multicolumn{2}{|c|}{ Gray marl. } & \multicolumn{2}{|c|}{ Green marl. } & \multicolumn{2}{|c|}{ Chocolate marl. } \\
\hline & $\begin{array}{l}\text { Thick- } \\
\text { ness. }\end{array}$ & $\mathrm{I}_{22} \mathrm{O}$ & $\begin{array}{c}\text { Thick- } \\
\text { ness. }\end{array}$ & $\mathrm{K}_{2} \mathrm{O}$ & $\begin{array}{l}\text { Thick- } \\
\text { ness. }\end{array}$ & $\mathrm{K}_{2} \mathrm{O}$. \\
\hline 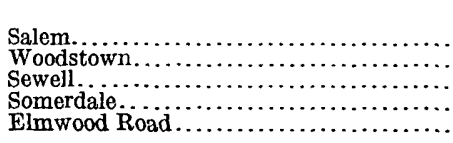 & \begin{tabular}{rrr} 
Ft. & in. \\
12 & 4 \\
12 & \\
8 & 4 \\
\hdashline & 9 & 7
\end{tabular} & $\begin{array}{r}\text { Pet cent. } \\
6.19 \\
6.12 \\
6.09 \\
6.01\end{array}$ & $\begin{array}{rr}\text { Ft. } & \text { in. } \\
9 & \\
11 & 7 \\
10 & 10 \\
9 & 1 \\
12 & 11\end{array}$ & $\begin{array}{r}\text { Per cent. } \\
7.19 \\
7.58 \\
7.52 \\
7.35 \\
7.26\end{array}$ & $\begin{array}{rr}\text { Ft. } & \text { in. } \\
8 & 9 \\
15 & 5 \\
18 & \\
28 & 2\end{array}$ & $\begin{array}{r}\text { Per cent. } \\
\text { a } 7.26 \\
6.69 \\
5.99 \\
6.32 \\
6.32\end{array}$ \\
\hline 。 & 107 & b 6.11 & 108 & b 7.39 & 146 & b 6.29 \\
\hline
\end{tabular}

$a$ Not characteristic chocolate marl; may belong with overlying bed.

$b$ Average weighted according to the thicknesses of the beds at their respective localities.

The middle bed or green marl is distinctly richer in potash than the other beds, but probably all contain sufficient potash to be considered workable by any process that could utilize the richest bed.

The following table gives a summary for the five districts enumerated of the data regarding the thickness of the marl as a whole and of the amount and value of the contained potash:

Summary of thickness of the Hornerstown and Navesink marls and of estimates of amount and value of the contained potash for five districts ranging northeastward from Salem . County, into Burlington County.

\begin{tabular}{|c|c|c|c|c|c|c|c|c|c|c|}
\hline \multirow{3}{*}{ District. } & 1 & 2 & 3 & 4 & 5 & 6 & . & 7 & 8 & \\
\hline & \multirow{2}{*}{$\begin{array}{l}\text { Num- } \\
\text { ber of } \\
\text { holes } \\
\text { (in } \\
\text { cludes } \\
\text { wells } \\
\text { cited). }\end{array}$} & \multirow{2}{*}{$\begin{array}{l}\text { Aver- } \\
\text { age } \\
\text { thick- } \\
\text { ness. }\end{array}$} & \multirow{2}{*}{\begin{tabular}{|l|} 
Num- \\
ber of \\
Survey \\
borings.
\end{tabular}} & \multirow{2}{*}{$\begin{array}{l}\text { Aver- } \\
\text { age } \\
\text { thick- } \\
\text { ness at } \\
\text { Survey } \\
\text { borings }\end{array}$} & \multirow{2}{*}{$\begin{array}{c}\text { Aver- } \\
\text { age } \\
\text { content } \\
\text { of } \mathrm{K}_{2} \mathrm{O} .\end{array}$} & \multirow{2}{*}{$\begin{array}{l}\text { Esti- } \\
\text { mated } \\
\text { content } \\
\text { of pot- } \\
\text { ash per } \\
\text { acre in } \\
2.5 \text {-acre } \\
\text { tract. }\end{array}$} & \multicolumn{2}{|c|}{$\begin{array}{c}\text { Value of potash } \\
\text { per ton of } \\
\text { greensand. } a\end{array}$} & \multicolumn{2}{|c|}{$\begin{array}{l}\text { Value of potash } \\
\text { per acre of } \\
\text { ground. } a\end{array}$} \\
\hline & & & & & & & $\begin{array}{c}\text { At } \$ 2.50 \\
\text { per } \\
\text { unit. }\end{array}$ & $\begin{array}{c}\text { At } \$ 1.50 \\
\text { per } \\
\text { unit. }\end{array}$ & $\begin{array}{c}\text { At } \$ 2.50 \\
\text { per } \\
\text { unit. }\end{array}$ & $\begin{array}{c}\text { At } \$ 1.50 \\
\text { per } \\
\text { unit. }\end{array}$ \\
\hline $\begin{array}{l}\text { Salem............ } \\
\text { Woodstown..... } \\
\text { Sewell.......... } \\
\text { Somerdale...... } \\
\text { Marlton......... }\end{array}$ & $\begin{array}{r}9 \\
12 \\
44 \\
11 \\
20\end{array}$ & $\begin{array}{r}\text { Feet. } \\
30 \\
37 \\
38 \\
41 \\
49\end{array}$ & $\begin{array}{l}2 \\
3 \\
3 \\
3 \\
2\end{array}$ & $\begin{array}{r}\text { Feet. } \\
20 \\
32 \\
34 \\
26 \\
50\end{array}$ & $\begin{array}{c}\text { Per } \\
\text { cent. } \\
6.62 \\
6.80 \\
6.50 \\
6.66 \\
6.50\end{array}$ & $\begin{array}{l}\text { Tons. } \\
3,800 \\
6,300 \\
6,400 \\
5,200 \\
9,400\end{array}$ & \begin{tabular}{|r|}
$\$ 13.24$ \\
13.60 \\
13.00 \\
13.32 \\
13.00
\end{tabular} & $\begin{array}{r}87.94 \\
8.16 \\
7.80 \\
7.99 \\
7.80\end{array}$ & $\begin{array}{r}\$ 760,000 \\
1,260,000 \\
1,280,000 \\
1,040,000 \\
1,880,000\end{array}$ & $\begin{array}{r}\$ 456,000 \\
756,000 \\
768,000 \\
624,000 \\
1,128,000\end{array}$ \\
\hline $\begin{array}{l}\text { Total or } \\
\text { average. }\end{array}$ & 96 & 40 & 13 & 32 & 6.60 & 6,790 & 13.23 & 7.94 & $1,353,600$ & 812,100 \\
\hline
\end{tabular}

$a$ The values given in columns 7 and 8 have no relation to the present value of the land, for they are de pendent upon the successful extraction of the potash by processes of which the success and the cost of installation and operation have not yet been commercially demonstrated.

In column 1 of the above table are included all wells and borings from which measurements were obtained in these five districts. Of the 44 listed under Sewell, 25, made by the West Jersey Marl \& Transportation Co. (see p. 51) stopped at the chocolate marl. The record of these holes was supplemented by adding to the average thickness of the bank and green marls the average thickness of the 
chocolate marl as determined at holes 8 to 10 . The resulting average compares very well with the averages for the adjacent districts.

In column 2 the final average is weighted according to the number of holes and the average thickness at the respective localities.

In column 3 only Survey borings which entered the Hornerstown and Navesink marls are included.

In column 4 the final average is weighted according to the number of holes and the average thickness at the respective localities.

In columns 5 and 6 the final averages are weighted according to the average thickness and potash content of the marl at the respective localities.

In column 7 the final averages are not weighted.

In column 8 the final averages are weighted according to the estimated tonnage per acre at the respective localities.

In the region from Medford to Birmingham and Pemberton seven wells, which show an average thickness of about 45 feet for the combined Hornerstown and Navesink marls, indicate the northeastward continuation of the marl in commercial thickness beyond the region explored by Survey borings.

At Jobstown 56 feet of marl probably referable to the Hornerstown and Navesink is reported. The records of three wells at Wrightstown and New Egypt show great thicknesses of marl, parts of which are probably referable to the Manasquan or Vincentown. They suggest, however, the northeastward continuation of a great body of the Navesink and Hornerstown marls.

Northeast of Sykesville the two beds are separated by the Redbank sand. At Hornerstown a well penetrated 22 feet of green marl and 24 feet of gray marl, probably assignable respectively to the Hornerstown and Navesink. Between these beds lies 15 feet of more or less marly material thought to represent the Redbank. Near Eatontown and at Crawford Hill (locality 119) measurements by Dr. Kümmel indicate a thickness of 20 to 25 feet of Hornerstown marl. Thus it appears that in the region where the Hornerstown and Navesink marls are distinct they tend to maintain thicknesses which if combined would equal or exceed their combined thickness southwest of Sykesville. Each of these beds is present in commercial thickness in Monmouth County.

In Monmouth County the Cream Ridge and Marlboro districts probably afford the most favorable conditions for commercial development of the Navesink marl, and the Hornerstown, Freehold, and Eatontown districts are probably best for the exploitation of the Hornerstown marl.

Comparatively few analyses and no complete measurements of thickness of the Manasquan marl are available, but the data at $88625^{\circ}-22-8$ 
hand for localities where it is accessible suggest that the more glauconitic portions of the marl are thinner and contain from 2 to 4 per cent less potash than the averages for the combined Navesink and Hornerstown given in the above table. It is thus probably unsuited for the commercial extraction of potash, but there is no apparent reason why it might not again find favor for direct application as a fertilizer to soils deficient in potash or phosphoric acid.

\section{GENERAL ESTIMATES FOR ENTIRE MART BELT.}

Washington ${ }^{48}$ estimates that the greensand beds in New Jersey contain $2,034,000,000$ metric tons, equivalent to about $2,243,114,000$ short tons of potash. This estimate is based on the assumption of a bed of greensand 6 meters (about 20 feet) thick, containing 6 per cent of potash $\left(\mathrm{K}_{2} \mathrm{O}\right)$, and occupying a belt 160 kilometers (99.4 miles) long and 16 kilometers (9.9 miles) wide. These assumptions appear to be fully justified, except, perhaps, that for the width of the belt. The marl doubtless underlies all that portion of the State southeast of the line of its outcrop and contains potash throughout its breadth, a much wider area than the 16-kilometer strip. Most of the deposit, however, is inaccessible because of the overburden, which, on account of the geologic structure, increases toward the southeast. In Monmouth County, as previously shown, the part of the marl accessible by open-pit mining occupies an area 10 miles or more wide, though much of this area is also underlain by the Redbank sand. Farther southwest the similarly accessible portion of the belt is much narrower.

In Monmouth County the Navesink and Hornerstown marls are distinct, but for purposes of computation they may be considered together as if occupying a single belt, as they do farther southwest.

The average of 25 measurements, at intervals of 4 miles, across the marl belt as mapped is 2.1 miles. From the table on page 104, an average thickness of 40 feet may be assumed for the combined beds and a potash content of 6.6 per cent. The accessible portion of the greensand mass may thus be considered as a triangular prism 100 miles long, 2.1 miles wide, and 40 feet thick along its southeast border but wedging out along its northwest border. The total potash content of such a prism would be approximately 513,905,000 short tons. Of this quantity part has been removed by stream erosion and part is doubtless so deeply covered by Quaternary deposits that it may not be considered accessible. Thus if one-half is deducted, there remains about $256,953,000$ short tons of potash that could be mined by open pits. This figure is probably conservative.

48 Washington, H. S., Italian leucite lavas as a source of potash: Met. and Chem. Eng., vol. 18, p. 71, 1918. 
The average annual importation of potash $\left(\mathrm{K}_{2} \mathrm{O}\right)$ for the five years immediately preceding the war, including 1914 , was 257,143 short tons. At this rate the New Jersey greensand deposit would furnish enough potash to supply the needs of the United States for nearly 1,000 years, if only the material obtainable by open-pit methods were used.

Should it ever become practicable to use underground methods of mining the available quantity of potash would be enormously increased. Wells southeast of the marl belt and along the shore indicate a thickening of the greensand belts in the direction of the dip. There are, however, no data about the maintenance or change of quality in that direction. The maximum recorded depth of the top of the Hornerstown appears to be 1,900 feet in the well at Atlantic City.

\section{SUMMARY FOR LIME SAND.}

The lime sand in probable commercial thickness is exposed or has been recognized in wells as far north as Wrightstown. Northeastward from this place the Vincentown sand becomes predominantly quartzose. The lime sand is reported as 25 feet thick in Salem County, but at the well of the Salem Water Co., at Quinton, it is 108 feet thick, and at Atlantic City 460 feet thick. In the well of William J. Irick, near Vincentown, it is 31 feet thick, and at Woodstown it is 10 feet or more thick. The maximum reported content of carbonate of lime is 84.7 per cent in a sample from Mannington Township, Salem County, but the average of three samples from that township gave only 66 per cent; 80 per eent material is reported from locality 61 , west of Clementon, Camden County. No systematic measurements or samples of the lime sand are available. Ordinarily it has considerable overburden and lies a mile or more from available sites for greensand exploitation.

\section{COMMERCIAL DEVELOPMENT.}

Although small amounts of potash have been manufactured from New Jersey greensand and marketed, there has been as yet no large-scale commercial operation or production. In 1916 the Waverly Chemical Co., of Camden, N. J., under the direction of Samuel Peacock, was regularly producing from greensand dug near Sewell a small output of hydrated carbonate of potash for the cutglass industry. ${ }^{49}$ No further production by this company has been reported to the Geological Survey.

In the same year ${ }^{50}$ the Kaolin Products Corporation was operating a plant at Jones Point, N. Y., on Hudson River about 40 miles

19 Gale, H. S., Potash in 1916: U. S. Geol. Survoy Mineral Resources, 1916, pt. 2, p. 130, 1917.

${ }^{50}$ Gale, H. S., op. cit. 
above New York City. The plant was designed to produce 1 ton of potash a day but was only experimental and not intended for commercial production. The process as at present developed is described below in the account of the Eastern Potash Corporation. In 1917 the company, having changed its name to the American Potash Corporation, continued experimental operations at Jones Point ${ }^{51}$ and claimed to have solved the difficulties of extracting potash on a commercial scale from the greensand of New Jersey. Among the proposed by-products were "agricultural lime," brick, tile, and artificial stone. No production of potash was reported by the company during the year.

The Eastern Potash Corporation was subsequently organized to take over the rights and property of the American Potash Corporation in so far as they related to the production of potash and byproducts from greensand. This corporation, with offices in New York, continued the experimental work at the Jones Point plant and produced and marketed in 1918 a small quantity of high-grade caustic potash. The company now has under construction near New Brunswick, N. J., a plant designed to treat 1,000 tons of greensand per day. According to a recently published statement ${ }^{52}$ the process which this company claims to have demonstrated commercially consists in grinding the greensand in ball mills to 200 mesh, and then digesting the material with milk of lime in an autoclave or a special type of continuous digestor for 30 to 60 minutes with steam at a pressure of 200 pounds. The lime $(\mathrm{CaO})$ should equal the weight of the greensand. The digested material is filtered twice, and a solution containing about 80 per cent of the potash in the charge is evaporated in a multiple-type evaporator from an original strength of about 2 per cent of potash to about 45 per cent.

This solution can be further concentrated to produce the ordinary 90 per cent solid caustic potash. ${ }^{52 a}$ The excess steam from the digestion and other sources of waste heat from the plant will be utilized for evaporation. For the manufacture of tile or brick the residue is mixed with sand. The hydrous calcium silicate and excess lime hydrate serve as binders, and the product is hardened by steam.

The Atlantic Potash Co. (Inc.), ${ }^{53}$ with offices in New York, was organized early in 1917 to produce potash from greensand by a process invented by G. F. von Kolnitz. It has mined a considerable amount of greensand at its pits near Marlton, in Burlington County,

${ }^{61}$ Gale, H. S., and Hicks, W. B., Potash in 1917: U. S. Geol. Survey Mineral Resources, 1917, pt. 2, p. 440 1918.

52 Wells, A. E., The potash industry of the United States and its possibilities for future production: Bur. Mines Minerals Inv., preliminary report, pp. 15-16, August, 1919.

62a Shreve, R. M., Potash recovery in New Jersey: Chem. Age, May, 1920. See also later publications by same author: Action of lime on greensand: Jour. Ind. and Eng. Chem., vol. 13, pp. 693-699, August, 1921; Greensand as a source of potash: Chem. and Met. Eng., vol. 25, p. 1056, December 7, 1921.

${ }_{68}$ Gale, H. S., and Hicks, W. B., op. cit. 
N. J. (see Pls. II and VIII, $A$ ), and has marketed a small quantity of high-grade potash extracted therefrom in its experimental plant at Stockertown, $\mathrm{Pa}$. The process consists in preheating the greensand to $350^{\circ} \mathrm{C}$., mixing it with calcium chloride, passing the mixture through a furnace at about $850^{\circ} \mathrm{C}$., leaching the product, and finally obtaining potassium chloride by evaporation and crystallization. The company had suspended operations by the fall of 1918 but was planning to erect a plant on its ground near Marlton. No further progress has been reported to the Survey.

The large-scale experiments of F. Tschirner at Yorktown ${ }^{54}$ in 1917 led to the establishment of the R. S. Ryan Co.'s plant at Reeves station (Pl. IX, D), 2 miles north of Medford, in Burlington County, where the company had acquired ground. The plant, which is regarded as only for commercial experiment, handles about 50 tons of greensand and produces from 2 to 3 tons of potassium chloride $(\mathrm{KCl})$ per day. The process consists in grinding greensand and lime sand, taken from the company's pits near the plant, mixing these with salt, and heating the mixture in a rotary kiln. The clinker is leached in water, and the potassium and sodium chlorides are removed by evaporation and crystallization. Most of the sodium chloride is recovered and used over again. Potassium chloride, running 88 to 90 per cent, with a little potassium sulphate, is produced. By March, 1919, the company had sufficiently overcome initial difficulties to start commercial operation. In September of the same year the plant was reported closed. The figures for production are not available.

In the fall of 1918 the newly organized Reduction \& Concentration Corporation acquired a factory building and grounds at Gloucester, N. J., for rendering soluble the potash in greensand and making complete fertilizer in which was to be incorporated the treated greensand. Preliminary arrangements were made for utilizing greensand from properties of the Norcross \& Edmunds Co. at Birmingham and of the West Jersey Marl \& Transportation Co. at Sewell. Installation of machinery and experimental work were said to be in progress from January to March, 1919, when the writer was in the vicinity, but no information as to the process was divulged, and no opportunity was afforded to view the operations. No production and no further activity of the corporation have been reported to the Survey.

In 1918 the Coplay Cement Manufacturing Co., of Coplay, Pa., which had recently installed a Cottrell dust-collecting system and equipment for the extraction of potash from flue dusts, experimented with greensand from Birmingham, N. J., as a constituent of its cement mixture to see if the amount of potash recoverable from 
these dusts could be increased. The company's usual mixture contained about 1 per cent of potash. The greensand employed contained about 7 per cent of potash, so that its use in the proportions selected for the experiments would nearly double the amount of potash available for volatilization. The experiments showed that the potash was largely volatilized, and that the cement, though darker colored on account of the iron in the greensand, was salable under the market conditions then existing. The company next acquired greensand deposits near Kirkwood, in Camden County (locality 60, Pl. II), and began commercial utilization of the greensand. After a few runs, but not from any difficulty arising from the use of greensand, it became necessary to shut down the dustcollecting units of the plant. These were still inactive in October, 1919 , but resumption of activity was expected if the potash market seemed favorable.

A number of other processes for the extraction of potash from greensand have been devised and most of them patented. None of these processes, however, has reached so advanced a stage of large-scale experimentation as those above described. ${ }^{55}$

\section{OUTLOOK.}

The development of a potash industry based on the New Jersey greensands depends on the ability of the manufacturers to compete not only with foreign producers but also with American producers.

According to Hicks ${ }^{56}$ the prices of German potash salts delivered before the war under special contracts for large quantities direct from the source of production to Gulf and Atlantic ports were as follows:

Wholesale prices per short ton of potash salts c. i. f. Atlantic ports, 1911-1914.a

\begin{tabular}{|c|c|c|c|c|c|c|c|c|}
\hline \multirow[b]{2}{*}{ Potash salt. } & \multirow[b]{2}{*}{$\begin{array}{c}\text { Approxi- } \\
\text { mate per- } \\
\text { centage } \\
\text { of potash } \\
\left(\mathrm{K}_{2} \mathrm{O}\right)\end{array}$} & \multicolumn{3}{|c|}{$1911-1913$} & \multicolumn{4}{|c|}{$1914 b$} \\
\hline & & $\begin{array}{c}\text { List } \\
\text { price. }\end{array}$ & $\begin{array}{c}\text { Dis- } \\
\text { count.c }\end{array}$ & $\begin{array}{c}\text { Net } \\
\text { price. }\end{array}$ & $\begin{array}{c}\text { List } \\
\text { price. }\end{array}$ & $\begin{array}{c}\text { Dis- } \\
\text { count.c }\end{array}$ & $\begin{array}{c}\text { Net } \\
\text { price. }\end{array}$ & $\begin{array}{l}\text { Approxi- } \\
\text { mate net } \\
\text { price per } \\
\text { unit of } \\
\text { potash } \\
(20 \\
\text { pounds } \\
\left.\text { of } \mathrm{K}_{2} \mathrm{O}\right) .\end{array}$ \\
\hline 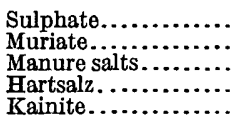 & $\begin{array}{l}48.6 \\
50.0 \\
20.0 \\
16.0 \\
12.4\end{array}$ & $\begin{array}{r}\$ 46.30 \\
38.05 \\
13.30 \\
10.65 \\
8.25\end{array}$ & $\begin{array}{r}\$ 6.95 \\
5.71 \\
2.06 \\
1.65 \\
1.28\end{array}$ & $\begin{array}{r}\$ 39.35 \\
32.34 \\
11.24 \\
9.00 \\
6.97\end{array}$ & $\begin{array}{r}\$ 47.58 \\
39.07 \\
13.58 \\
10.87 \\
8.36\end{array}$ & $\begin{array}{r}\$ 7.14 \\
5.86 \\
2.10 \\
1.68 \\
1.30\end{array}$ & $\begin{array}{r}\$ 40.43 \\
33.21 \\
11.48 \\
9.19 \\
7.06\end{array}$ & $\begin{array}{r}\$ 0.83 \\
.66 \\
.57 \\
.57 \\
.57\end{array}$ \\
\hline
\end{tabular}

a Federal Trade Commission report on the fertilizer industry, 1916, p. 155.

$b$ These prices, which were for January to June, 1914, were increased slightly during the later part of the year. See Oil, Paint, and Drug Reporter, vol. 85, p. 59, 1914.

$c 15$ per cent discount on sulphate and muriate and $15 \frac{1}{2}$ per cent on 20 per cent manure salts, hartsalz, and kainite.

${ }^{65}$ See Gale, H. S., Potash in 1916: U. S. Geol. Survey Mineral Resources, 1916, pt. 2, pp. 126-129, 1917. Gale, H. S., and Hicks, W. B., Potash in 1917: U. S. Geol. Survey Mineral Resources, 1917, pt. 2, pp. 440, 442-446, 1918; also Hicks, W. B., Potash in 1918: U. S. Geol. Survey Mineral Resources, 1918, pt. 2, pp. 385-445, 1920. Each of these papers contains a list of patents and a bibliography.

of Hicks, W. B., op. cit., pp. 398-401. 
As will be observed from the table, net prices to large importers varied from 57 cents per unit ( 20 pounds of $\mathrm{K}_{2} \mathrm{O}$ ) for the lowest-grade product to 83 cents for sulphate. The list prices, which are generally shown in market quotations in the United States, correspond to 67 cents per unit for the low-grade material and 98 cents for sulphate. Ocean freight rates to the United States on these salts in bulk from Hamburg averaged about $\$ 2$ per metric ton to northern ports and $\$ 2.50$ to $\$ 2.90$ to southern ports.

After the embargo of January 30,1915 , placed on the exportation of potash salts from Germany, the prices of these salts rose rapidly. Early in 1915, market quotations on 80 per cent muriate were around $\$ 115$ a ton and gradually rose to $\$ 500$ a ton in December. The quotations in 1916 varied from $\$ 300$ to $\$ 490$ a ton, in 1917 from $\$ 325$ to $\$ 450$ a ton, and in 1918 from $\$ 260$ to $\$ 350$ a ton. These quotations are not indicative of the actual selling price of potash materials, as only limited quantities of muriate were on the market and muriate was at a premium because of its use as a raw material in the manufacture of various refined potassium salts. The actual selling price in the eastern markets of the domestic output was about $\$ 4.87$ per unit in $1916, \$ 4.79$ in .1917 , and $\$ 4.61$ in 1918. These data are shown in the following table.

Wholesale price of potash in the United States, 1915-1918.

\begin{tabular}{|c|c|c|c|c|c|c|c|c|}
\hline \multirow{3}{*}{ Year. } & \multicolumn{6}{|c|}{ Market quotations of 80 per cent muriate. $a$} & \multicolumn{2}{|c|}{$\begin{array}{l}\text { Approximate aver- } \\
\text { age selling price } \\
\text { per unit of } \mathrm{K}_{2} \mathrm{O} \text { of } \\
\text { domestic output. }\end{array}$} \\
\hline & \multicolumn{3}{|c|}{ Per short ton of salt. } & \multicolumn{3}{|c|}{ Per unit of $\mathrm{K}_{2} \mathrm{O}$. } & \multirow{2}{*}{$\begin{array}{c}\text { F. o. b. } \\
\text { plant. }\end{array}$} & \multirow{2}{*}{$\begin{array}{l}\text { Eastern } \\
\text { markets. }\end{array}$} \\
\hline & High. & Low. & Average. & High. & Low. & Average. & & \\
\hline $\begin{array}{l}1915 \ldots \ldots \\
1916 \ldots \ldots \\
1917 \ldots \ldots \\
1918 \ldots \ldots\end{array}$ & $\begin{array}{r}\$ 500 \\
490 \\
450 \\
350\end{array}$ & $\begin{array}{r}\$ 115 \\
300 \\
325 \\
260\end{array}$ & $\begin{array}{r}\$ 245 \\
415 \\
380 \\
315\end{array}$ & $\begin{array}{r}\$ 10.00 \\
9.80 \\
9.00 \\
7.00\end{array}$ & $\begin{array}{r}\$ 2.30 \\
6.00 \\
6.50 \\
5.20\end{array}$ & $\begin{array}{r}85.90 \\
8.30 \\
7.60 \\
6.30\end{array}$ & $\begin{array}{r}\$ 3.14 \\
4.37 \\
4.29 \\
4.11\end{array}$ & $\begin{array}{r}83.64 \\
4.87 \\
4.79 \\
4.61\end{array}$ \\
\hline
\end{tabular}

$a$ Quotations for 1915 and 1916 taken from Jour. Ind. and Eng. Chemistry and for 1917 and 1918 from Oil, Paint, and Drug Reporter.

When the armistice was signed in November, 1918, only a few large producers in the United States had made their original investments out of the potash industry, many plants had been operated only a short time, and others were under construction. About one-third of the potash produced in 1918 was still in the hands of producers, money for operating expenses had been advanced on the potash held in storage, and developments had gone forward under the prevailing price of $\$ 4$ to $\$ 5$ per unit of potash. Anticipation that low-priced potash from foreign sources would be available followed the armistice agreement, checked sales of domestic potash, and caused the price to fall to about $\$ 2.50$ per unit-a price lower than the cost of production of many producers. These conditions caused a crisis in the potash industry, and producers began to close their plants. By the early part of 1919 nearly all producers had shut down and some had gone out of business.

The cost of production of American salts is summarized by Gale and Hicks ${ }^{57}$ as follows:

Available data on the cost of producing potash from the various American sources are very meager, but if the following estimates of cost production are correct they indicate that undoubtedly some of the large developments will survive. Condra gives the cost of producing potash in the alkali-lake region of Nebraska as between $\$ 20$ and $\$ 44$ a short ton, or an average of $\$ 30$ a short ton of crude salts. This corresponds

67 Op. cit., p. 403. 
to an average of about $\$ 120$ a ton of potash $\left(\mathrm{K}_{2} \mathrm{O}\right)$. The conditions as regards labor, fuel, and supplies in this region are very difficult, and the cost should be considerably reduced if such conditions are improved. It has been stated that sulphate of potash can be produced from alunite at Marysvale, Utah, at approximately $\$ 20$ a ton (equivalent to about $\$ 40$ a ton of $\mathrm{K}_{2} \mathrm{O}$ ), and that if an aerial tramway were installed the cost would be reduced 50 per cent. Porter estimates that the present cost of production, exclusive of royalty, depreciation, and similar items, by the Security Cement $\&$ Lime Co., Hagerstown, Md., is about $\$ 30$ a ton of pure potash $\left(\mathrm{K}_{2} \mathrm{O}\right)$ packed on board cars, and that under normal conditions the price might be reduced 50 per cent. Treanor, from his experiences as manager of the Riverside Portland Cement Co., thinks the cost of saving potash from flue dust may run $\$ 100$ a ton of $\mathrm{K}_{2} \mathrm{O}$ for the first month, may average $\$ 40$ a ton of $\mathrm{K}_{2} \mathrm{O}$ the first year, and that it may ultimately be reduced to less than $\$ 20$ a ton of $\mathrm{K}_{2} \mathrm{O}$.

Estimates of the cost of American production thus run from $\$ 20$ to $\$ 120$ a ton of $\mathrm{K}_{2} \mathrm{O}$ or from $\$ 0.20$ to $\$ 1.20$ per unit.

Wells ${ }^{58}$ in describing the plant of the Eastern Potash Corporation estimates that the cost of producing caustic potash in a plant with a capacity of 1,000 tons of greensand per day, including interest and general plant depreciation, may reasonably be as much as $\$ 1.50$ per unit of $\mathrm{K}_{2} \mathrm{O}$. Such a plant would produce about 45 to 50 tons of $\mathrm{K}_{2} \mathrm{O}$ as caustic potash and would turn out about 2,000,000 brick per day. It should, however, be borne in mind that the cost of raw material for the brick is greater than that for ordinary brick and that the by-product brick, to find a suitable market, must possess some special attractiveness such as color, endurance, or adaptability to particular uses. With the requirement of a specialized market the disposal of so much brick might prove a problem in itself.

It is doubtful if companies making potash their only product in the treatment of greensand can do so for less than the $\$ 1.50$ per unit estimated for the Eastern Potash Corporation.

The experience of Treanor, cited above, appears to indicate that after the installation of a dust-collecting and potash-refining system in a cement plant potash may be recovered from the dust rather cheaply. Wells, ${ }^{59}$ however, thinks that the cost of the high-grade product, allowing for royalties, selling costs, and storage charges, would be nearly $\$ 1.80$ per unit.

If these figures are at all accurate it is evident that the cost of producing potash from greensand, even in conjunction with cement manufacture, is greater than that of producing it from alunite and some of the western brines. The greensand product has the advantages of proximity to market and of low freight cost.

In view of the present disturbed state of industrial conditions in Germany and of the heavy war taxes it seems certain that the cost

${ }^{53}$ Wells, A. E., The potash industry of the United States and its possibilities for future production: Bur. Mines Minerals Inv., preliminary report, p. 16, August, 1919.

69 Idem, p. 7. 
of German potash will hereafter greatly exceed and perhaps be as much as double pre-war prices. On the other hand, there is the possibility that in the United States the cost of labor and fuel may have reached its peak and that with the resumption of industries interrupted by the war and with increased production these costs may decline.

The American potash industry thus bids fair to be on a nearly even basis with foreign potash industries. Whether or not greensand may have a place in the American potash industry will depend on how well the greensand operators may be able to compete with western producers.

\section{AVAILABILITY OF POTASH IN GREENSAND.}

The scarcity of potash and the high prices of fertilizers during the war led many farmers to think again of greensand as a source of fertilizer. Although accounts of its use in the early reports were highly favorable, the results of more recent local applications were contradictory, and the writer received many inquiries about the availability of the potash in greensand.

From the standpoint of the fertilizer manufacturer the potash is not considered available because of its slight solubility in water. Recent experiments conducted by True and Geise, of the Bureau of Plant Industry, United States Department of Agriculture, show that plants in their early growing stages will assimilate potash from greensand as effectively as from the usual soluble commercial potassium salts. These authors ${ }^{80}$ used two sets of carefully controlled pot cultures of wheat and red clover with nutrient solutions. In one set the potash was supplied by the usual commercial salts; in the other set potash was supplied by greensand in proportions such as those formerly employed in agricultural practice, all other sources of potash being excluded. They reached the following conclusions:

It has been shown by pot experiments carried out with crushed quartz and Shive's culture solution as a basis that greensands and greensand marls from Virginia and $\mathrm{New}$ Jersey are able to supply sufficient potassium to satisfy the demand of Turkey Red wheat and red clover during the first two months of their growth. This enables them to make a greater dry weight of tops than was seen in similar cultures in which the potassium demand was supplied by potassium chlorid, potassium sulphate, and potassium phosphate. The prompt availability of sufficient potassium to meet the needs of many, perhaps most, farm crops seems to be indicated.

It is reported that the New Jersey Agricultural Experiment Station has been working on the same problem and has reached similar conclusions.

In a letter to the Director of the United States Geological Survey Dr. True points out that land which already has a sufficient supply

${ }^{60}$ True, R. H., and Geise, F. W., Experiments on the value of greensand as a source of potassium for plant culture: Jour. Agr. Research, vol. 15, pp. 483-492, Dec .2, 1918. 
of potash and the other ingredients supplied by greensand marl will not be benefited by application of it. This may account in some measure for the contradictory nature of the reported results of its use. Dr. True further states that arrangements have been made for the shipment of three carloads of greensand from deposits near Marlboro, N. J., to the vicinity of Florence, S. C., where it is to be applied to fields known to be deficient in potash. Results of interest and value are to be expected from these experiments.

More recent experiments along a somewhat different line have been carried out by McCall and Smith, of the Maryland Agricultural Experiment Station. These authors ${ }^{61}$ composted greensand with sulphur, soil, and manure in varying proportions, taking samples from time to time, extracting these samples with distilled water, and analyzing the water extracts for their acidity and their sulphate and potassium content. Two types of greensand were used, one from Sewell, N. J., containing 5.88 per cent of potassium (K), and the other from Crownsville, Md., containing 1.42 per cent of potassium. Each compost had as a basis 1,500 grams of greensand, 500 grams of commercial flowers of sulphur, and 0, 250, or 500 grams of partly rotted yard manure, aid-dried and ground fine. In some of the tests Collington sandy loam and precipitated calcium carbonate were used, also small percentages of the sulphates of iron and alumina. The following results were obtained:

1. In composts consisting of greensand, manure, and soil in different proportions an appreciable amount of the potassium was made water-soluble through sulphofication.

2. The composts containing the largest proportion of manure developed the highest degree of acidity, oxidized the greatest amount of sulphur, and produced the largest quantity of water-soluble potassium.

3. The composts in which soil was substituted for a part of the manure developed less acidity, oxidized less sulphur, and produced a smaller amount of soluble potassium.

4. When all the manure was replaced by soil, the rate of sulphofication was so slow that at the end of 23 weeks only a very small amount of acidity had developed and very little potassium had been made soluble.

5 . When no organic matter was added the amounts of acidity and of soluble sulphates were no greater than might be accounted for by natural oxidation of the sulphur.

6. The addition of small amounts of ferrous and aluminum sulphates failed to stimulate sulphofication.

7. Calcium carbonate added to the sulphur-manure-soil compost produced a stimulating effect during the early part of the period but failed to increase the acidity, soluble sulphates, or potassium above the maximum reached by the corresponding composts in which no calcium carbonate was used.

8. More water-soluble potassium was formed in composts containing the highpotassium greensand, but a larger per cent of the total potassium present was liberated in the composts containing the low-potassium greensand.

\footnotetext{
61 McCall, A. G., and Smith, A. M., Effect of manure-sulphur composts upon the availability of the potassium of greensand: Jour. Agr. Research, vol. 19, pp. 239-256, June, 1920.
} 
9. In the composts containing manure the total amounts of potassium recovered in the water extracts varied from 9.1 per cent to a maximum of 41.3 per cent of the total initial amount present.

10. Our resultsindicate that the composting of greensand or of soil rich in potassium with sulphur and manure may prove to be a practical and efficient method for obtaining available potassium from comparatively insoluble materials.

In the opinion of the writer part of the benefit derived from the use of marl may be the result of an improved texture produced by the mechanical mixture of the greensand with the soil. For example, a mass of clayey greensand applied and worked into a light sandy soil would produce a more loamy texture besides furnishing potash. On the other hand, similar greensand applied to a stiff clayey soil would tend to emphasize the heaviness of such a soil and might be injurious.

\section{EARLIER VIEWS ON AGRICULTURAL VALUE.}

Little was known in the earlier days about potash in greensand marl and its part in the beneficial action of the marl upon crops. On the other hand, the importance of the phosphoric acid and lime as beneficial constituents was strongly urged. For those interested in reverting to the use of marl as a fertilizer it may be well to. repeat the conclusions drawn years ago by Cook: $:^{62}$

1. That the most valuable marls and those which will best pay the cost of long transportation are those which contain the largest percentage of phosphoric acid.

2. That the most durable marls are those containing carbonate of lime, the more the better.

3. That greensands containing but little of either phosphoric acid or carbonate of lime become active fertilizers when composted with quicklime.

4. That marls which are acid and burning from containing sulphate of iron can be rendered mild in properties and useful as fertilizers by composting with lime.

5. That crops particularly improved by it are all forage crops, grass, clover, etc.; for these the green marl may be spread upon the surface to the amount of from 100 to 400 bushels per acre. The crop is generally doubled and in some cases quadrupled by this application. Other marls must be used in larger quantities, but will produce good results.

Potatoes: For this crop marl seems to be a specific. It does not materially increase the growth of the vines, and the yield is not much greater, but the potatoes are smoother and fairer in the skin and dryer and of better quality when boiled. The marl is put on the potatoes in the hill at planting; if not acid, it is thrown directly on the tuber; if acid, the potato is first covered by earth and the marl thrown on or beside that. From 5 to 30 tons may be used on an acre.

Buckwheat: Most remarkable effects upon this crop are produced by marl. Two and one-half tons, or 50 bushels to the acre, spread on after sowing, have caused an equal amount of buckwheat to grow on land which otherwise was not worth cultivating.

Wheat, rye, oats, and corn are improved by the use of marl, though not with the striking results seen on the crops before mentioned. It is applied as a top dressing on the prepared ground, is spread on the surface before plowing, is worked in the hill or drill, or is composted with barnyard manure and spread on the ground according

62 Cook, G. H., Geology of New Jersey, pp. 452-453, 1868. 
to the farmer's judgment. From 5 to 30 tons and even more may be used upon an acre.

With any kind of garden or field crop it may be used and will be beneficial both to the crop and soil. It is free from the seeds of weeds, is dry and convenient to handleall of which recommend it to any snug farmer.

\section{MECHANICAL ANALYSES OF GREENSAND.}

\section{NATURE OF INVESTIGATION.}

In the course of drilling variations were observed in the texture of the marl and in the relative proportions of the different constituents. Quartz was present in all the samples in greater or less amounts and served as an adulterant, lowering the potash content. The claylike constituents, however, consisted in part at least, of finely divided glauconitic material, so that their presence might or might not mean a reduced potash content. In order to study the different constituents of the marl and their relative proportions in the principal beds of commercial thickness mechanical analyses were undertaken somewhat along the lines of the work of Cook ${ }^{63}$ and Ashley. ${ }^{64}$ The following investigations were carried out: (1) Wet separation to determine the relative proportions of coarser and finer constituents; (2) magnetic separation of coarser residues to determine the percentage of magnetic materials, chiefly glauconite; (3) sizing the products of the magnetic separation to determine the sizes and shapes of the mineral grains and the relative abundance of grains of certain sizes and shapes; (4) microscopic study of glauconite grains in thin section (for discussion see pp. 139-140); (5) chemical analyses of some of the products of the wet and magnetic separations (discussed below).

\section{PREPARATION OF SAMPLES.}

Composite samples, 15 in all, derived from 87 originals, were prepared to represent each bed of commercial thickness at each of the six localities explored. Each sample weighed approximately 100 grams and was made up of weighed portions of all samples taken from the given bed at the given locality, each in proportion to the thickness represented by it. The material was weighed without preliminary drying, but at the end check samples weighing 100 grams were dried under the same conditions to which the composite samples were subjected and reweighed to determine the loss of moisture in drying.

\section{WET SEPARATION.}

In a preliminary trial 100 grams of greensand was placed in a beaker, covered with water, stirred briskly one or two minutes with a glass rod, and allowed to settle for a few seconds. The liquid with finer particles in suspension was then decanted. This procedure

68 Cook, G. H., Geology of New Jersey, pp. 227-280, 1868.

64 Ashley, G. H., Notes on the greensand deposits of the United States: U. S. Geol. Survey Bull. 660, p. 30, 1918 . 
was repeated and continued for an hour and three-quarters. At first the material released by washing was of a brownish color and relatively heavy, settling in a comparatively few minutes. This disappeared after five or six washings, however, and a light yellowish green material was developed, which clouded the solution and appeared without evident diminution at every washing. Comparatively little of this cloudy matter had settled, even after standing over night. A few drops of dialyzed iron, added to the solution at the suggestion of George Steiger, caused the flocculation and precipitation of the fine suspended matter and the clearing of the solution.

A second preliminary trial was made to determine whether the cloudy material above mentioned was present as detached particles in the original sample or whether it was developed from the greensand grains by agitation in washing. About 25 grams of greensand in which claylike material was relatively abundant, was placed in a beaker on a stand under a faucet. The inflow of water was directed by a funnel to the bottom of the beaker. The "clay" was soon washed out and the solution cleared. Some cloudiness of the water was developed, however, when the greensand was agitated with a glass rod. This was done at intervals of a few minutes for a period of nearly four hours, and the cloudiness appeared at each agitation. The clear water was then poured off except about 50 cubic centimeters, in which the greensand was again stirred briskly with a rod. The cloudiness at once reappeared just as abundantly as at the early stages of the washing.

It was concluded that the glauconite grains were yielding fine particles either by mechanical wear of grain on grain or by the flow of water over the grains. Of the two agencies the former is apparently the more effective, because practically no cloudiness appeared during the constant flow of water through the beaker. The test suggests that much of the "clay" that is so abundant in some beds of greensand is really composed of finely comminuted glauconite grains. Its presence in the marl, therefore, does not necessarily imply poorer quality.

In making the separations tabulated below the following procedure was observed. After placing the weighed sample in a beaker somewhat more than enough distilled water to cover it was added. The greensand was then stirred vigorously with a rod for one minute and allowed to settle for 30 seconds, after which the cloudy liquid was decanted to a second beaker. These operations were repeated to a total of 10 times for the first five samples and 15 times for the remaining 10 samples. The washed greensand was then removed to a casserole, dried on a steam bath, and weighed. A few drops of dialyzed iron were added to the cloudy liquid, which was then allowed to settle, after which the clear water was decanted and the 
settlings dried and weighed in the same manner. In samples G-2, $\mathrm{G}-10, \mathrm{G}-13, \mathrm{G}-14$, and $\mathrm{G}-15$ the entire washing waters were dried without flocculation and precipitation by dialyzed iron.

Wet separations of composite samples of greensand from Survey borings.

\begin{tabular}{|c|c|c|c|c|c|c|c|c|}
\hline \multirow{2}{*}{ Locality. } & \multirow{2}{*}{$\begin{array}{l}\text { Sample } \\
\text { No. }\end{array}$} & \multirow{2}{*}{$\begin{array}{l}\text { Approxi- } \\
\text { mate } \\
\text { thickness } \\
\text { of bed. }\end{array}$} & \multirow{2}{*}{$\begin{array}{l}\text { Weight of } \\
\text { sample. }\end{array}$} & \multicolumn{2}{|c|}{$\begin{array}{l}\text { Residue from } \\
\text { washing. }\end{array}$} & \multicolumn{2}{|c|}{$\begin{array}{l}\text { Material washed } \\
\text { out. }\end{array}$} & \multirow{2}{*}{$\begin{array}{c}\text { Loss of } \\
\text { weightin } \\
\text { washing } \\
\text { and } \\
\text { drying. }\end{array}$} \\
\hline & & & & Grams. & $\begin{array}{l}\text { Per cent } \\
\text { (A). }\end{array}$ & Grams. & $\begin{array}{c}\text { Per cent } \\
\text { (B). }\end{array}$ & \\
\hline $\begin{array}{l}\text { Salem.......... } \\
\text { Woodstown..... } \\
\text { Sewell.......... } \\
\text { Somerdale...... } \\
\text { Elmwood Road. } \\
\text { Pemberton..... }\end{array}$ & 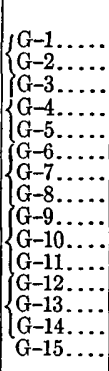 & $\begin{array}{r}\text { Feet. } \\
12 \\
11 \\
11 \\
11 \\
7 \\
8 \\
12 \\
13 \\
8 \\
6 \\
14 \\
4 \\
18 \\
23 \\
9\end{array}$ & $\begin{array}{l}\text { Grams. } \\
100 \\
100 \\
100 \\
100 \\
100 \\
100 \\
100 \\
100 \\
100.1 \\
100.12 \\
100.04 \\
100.04 \\
100.04 \\
100.07 \\
100.07\end{array}$ & $\begin{array}{l}93.44 \\
95.07 \\
77.04 \\
84.73 \\
86.65 \\
51.59 \\
79.75 \\
84.34 \\
39.47 \\
50.94 \\
69.42 \\
86.70 \\
94.39 \\
81.52 \\
75.24\end{array}$ & $\begin{array}{l}95.6 \\
97.3 \\
79.3 \\
85.7 \\
88.8 \\
53.4 \\
81.5 \\
86.2 \\
40.0 \\
52.4 \\
71.2 \\
88.3 \\
97.3 \\
84.3 \\
76.8\end{array}$ & $\begin{array}{r}4.25 \\
2.62 \\
20.07 \\
14.17 \\
10.95 \\
45.09 \\
18.05 \\
13.50 \\
59.19 \\
46.20 \\
28.07 \\
11.49 \\
2.62 \\
15.19 \\
22.70\end{array}$ & $\begin{array}{r}4.5 \\
2.7 \\
20.7 \\
14.3 \\
11.2 \\
46.6 \\
18.5 \\
13.9 \\
60.0 \\
47.6 \\
28.8 \\
11.8 \\
2.7 \\
15.6 \\
23.2\end{array}$ & $\begin{array}{r}\text { Grams. } \\
2.31 \\
2.31 \\
2.89 \\
1.10 \\
2.40 \\
3.32 \\
2.20 \\
2.16 \\
1.44 \\
2.98 \\
2.25 \\
1.85 \\
3.03 \\
3.36 \\
2.13\end{array}$ \\
\hline Average. & & & & & $a 80.5$ & & $a 19.5$ & 2.38 \\
\hline
\end{tabular}

a Average weighted according to the thicknesses of the respective beds.

For the check tests on loss of weight in washing and drying four samples were selected, weighed, dried over night on the steam bath, and reweighed with the following results:

Moisture determinations on samples of greensand.

\begin{tabular}{|c|c|c|c|c|}
\hline Locality. & $\begin{array}{c}\text { Field } \\
\text { No. of } \\
\text { sample. } a\end{array}$ & $\begin{array}{l}\text { Original } \\
\text { weight. }\end{array}$ & $\begin{array}{l}\text { Weight } \\
\text { at about } \\
100^{\circ} \mathrm{C} .\end{array}$ & $\begin{array}{l}\text { Loss in } \\
\text { weight. }\end{array}$ \\
\hline $\begin{array}{l}\text { Salem......... } \\
\text { Woodstown... }\end{array}$ & $\left\{\begin{array}{l}M-1 \ldots \ldots \\
M-8 \ldots \ldots \\
M-12 \ldots \\
M-16 \ldots\end{array}\right.$ & $\begin{array}{r}\text { Grams. } \\
100 \\
100 \\
100 \\
100\end{array}$ & $\begin{array}{r}\text { Grams. } \\
96.95 \\
97.19 \\
96.85 \\
97.49\end{array}$ & $\begin{array}{r}\text { Grams. } \\
3.05 \\
2.81 \\
3.15 \\
2.51\end{array}$ \\
\hline Average.. & & & & 2.88 \\
\hline
\end{tabular}

$a$ The field numbers are those used in the descriptions of the borings at Salem and Woodstown.

The loss of weight on drying for the four check samples is of the same order individually as for the samples subjected to wet separation, though the average is somewhat higher.

The percentage of fines or "clay" in the greensand at the six localitics named ranges from 2.7 to 60 and averages about 19.5.

\section{MAGNETIC SEPARATION.}

An interesting characteristic of glauconite is that it is moderately magnetic and may thus be separated from quartz and other nonmagnetic substances by passing the dried greensand through a strongly magnetic field. The residues from washing were presented successively in small quantities close under a glass plate placed 
against the poles of a powerful electromagnet. The glauconite was attracted and held to the glass plate so long as the plate was in contact with the poles of the magnet. By lowering the plate the glauconite could be dropped into any convenient receptacle. This action was repeated until no further results were shown, and thus fairly complete separations were obtained.

As tabulated below the numbers of the samples and the beds represented are the same as for the wet separations. Ten-gram portions of each sample were used, and the products of the separations were weighed.

Magnetic separation of samples of washed greensand.

\begin{tabular}{|c|c|c|c|c|c|c|c|c|}
\hline \multirow{2}{*}{ Locality. } & \multirow{2}{*}{$\begin{array}{c}\text { Sample } \\
\text { No. }\end{array}$} & \multirow{2}{*}{ Weight. } & \multicolumn{2}{|c|}{$\begin{array}{l}\text { Magnetic portion, } \\
\text { chiefly glauconite. }\end{array}$} & \multicolumn{2}{|c|}{$\begin{array}{l}\text { Nonmagnetic por- } \\
\text { tion, chiefly quartz. }\end{array}$} & \multirow{2}{*}{$\begin{array}{l}\text { Excess } \\
\text { or loss } \\
\text { after sep- } \\
\text { aration. }\end{array}$} & \multirow{2}{*}{$\begin{array}{c}\text { Glau- } \\
\text { conite } \\
\text { grains in } \\
\text { original } \\
\text { samplo } \\
\text { (CXA, } \\
\text { p. 118). }\end{array}$} \\
\hline & & & Grams. & $\begin{array}{l}\text { Percent } \\
\text { (C). }\end{array}$ & Grams. & $\begin{array}{l}\text { Per cent } \\
\text { (D). }\end{array}$ & & \\
\hline $\begin{array}{l}\text { Salem.......... } \\
\text { Woodstown..... } \\
\text { Sewell........... } \\
\text { Somerdale....... } \\
\text { Elmwood Road. } \\
\text { Pemberton...... }\end{array}$ & 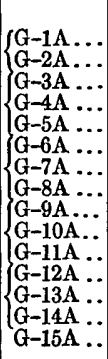 & $\begin{array}{r}\text { Grams. } \\
10 \\
10 \\
10 \\
10 \\
10 \\
10 \\
10 \\
10 \\
10 \\
10 \\
10 \\
10 \\
10 \\
10 \\
10\end{array}$ & $\begin{array}{l}8.87 \\
9.45 \\
8.09 \\
9.60 \\
9.30 \\
8.27 \\
9.77 \\
9.51 \\
9.32 \\
9.70 \\
9.62 \\
6.24 \\
9.50 \\
9.65 \\
5.27\end{array}$ & $\begin{array}{l}87.3 \\
94.1 \\
80.4 \\
96.0 \\
92.5 \\
82.3 \\
97.0 \\
94.5 \\
92.6 \\
96.6 \\
96.0 \\
62.5 \\
94.5 \\
96.0 \\
52.4\end{array}$ & $\begin{array}{r}1.29 \\
.59 \\
1.97 \\
.39 \\
.75 \\
1.78 \\
.30 \\
.55 \\
.74 \\
.34 \\
.40 \\
3.75 \\
.55 \\
.40 \\
4.79\end{array}$ & $\begin{array}{r}12.7 \\
5.9 \\
19.6 \\
3.9 \\
7.5 \\
17.7 \\
3.0 \\
5.5 \\
7.4 \\
3.4 \\
4.0 \\
37.5 \\
5.5 \\
4.0 \\
47.6\end{array}$ & $\begin{array}{l}\text { Gram. } \\
+0.16 \\
+.04 \\
+.06 \\
+.01 \\
+.05 \\
+.05 \\
+.07 \\
+.06 \\
+.06 \\
+.04 \\
+.02 \\
+.01 \\
+.05 \\
+.05 \\
+.06\end{array}$ & $\begin{array}{r}\text { Per cent. } \\
83.5 \\
91.6 \\
63.8 \\
82.2 \\
82.1 \\
43.9 \\
79.1 \\
81.5 \\
37.0 \\
50.6 \\
68.4 \\
55.2 \\
91.9 \\
80.9 \\
40.2\end{array}$ \\
\hline Average $a$. & & & & 89.9 & & 11.1 & & 73.1 \\
\hline
\end{tabular}

a Averages weighted according to thicknesses of beds represented.

The excess after weighing was probably due in part to the moisture taken from the humid air by the dried greensand during the operations of separation and weighing. The percentage of magnetic materials, chiefly glauconite, in the washed greensand is generally high, being more than 90 in 10 of the 15 samples and averaging 89.9 for all the beds represented. The percentage of glauconite grains in the unmodified greensand is shown for each bed at each locality in the last column of the table. The final average shows 73 per cent of glauconite for the entire thickness of the greensand examined at each of the six localities. This figure does not include the finely divided glauconitic material occurring in the greensand as mud or "clay" (B in the table on p. 118). No mechanical separation of this mud was attempted, but the chemical analyses on page 125 indicate that it is probably highly glauconitic.

\section{SIZE OF GRAINS.}

Both products of the magnetic separation (C and D of the table) were passed successively through a series of sieves having 20,40,60, 
80, and 100 meshes to the inch. The entire magnetic or nonmagnetic portion of each sample was used, so that the initial weights for the sizing operations were assumed to be the same as those of the separated portions shown in the table. The grains held on each sieve and in the receiver below the lowest sieve were weighed. From these weights the percentage of material of the different sizes in each sample were determined as shown in the following table:

Size of grains of glauconite, quartz, etc., in washed greensand.

\begin{tabular}{|c|c|c|c|c|c|c|c|c|c|}
\hline \multirow{3}{*}{ Locality. } & \multirow{3}{*}{$\begin{array}{c}\text { Sample } \\
\text { No. }\end{array}$} & \multicolumn{4}{|c|}{ Glauconite, etc. (C). } & \multicolumn{4}{|c|}{ Quartz, etc. (D). } \\
\hline & & \multirow{2}{*}{$\begin{array}{l}\text { Quan- } \\
\text { tity in } \\
\text { sample } \\
\text { (grams). }\end{array}$} & \multicolumn{3}{|c|}{ Quantity held on sieves. } & \multirow{2}{*}{$\begin{array}{c}\text { Quan- } \\
\text { tity in } \\
\text { sample } \\
\text { (grams). }\end{array}$} & \multicolumn{3}{|c|}{ Quantity held on sieves. } \\
\hline & & & Mesh. & Grams. & Per cent. & & Mesh. & Grams. & Per cent. \\
\hline \multirow[t]{2}{*}{ Salem............ } & \multirow[t]{2}{*}{ G-1A... } & \multirow[t]{2}{*}{8.87} & \multirow[t]{2}{*}{$\begin{array}{c}20 \\
40 \\
60 \\
80 \\
100 \\
100+\end{array}$} & $\begin{array}{r}0.30 \\
4.80 \\
2.85 \\
.59 \\
.29 \\
.03\end{array}$ & $\begin{array}{r}3.4 \\
54.2 \\
32.2 \\
6.7 \\
3.3 \\
.3 \\
\end{array}$ & \multirow[t]{2}{*}{1.29} & \multirow[t]{2}{*}{$\begin{array}{c}20 \\
40 \\
60 \\
80 \\
100 \\
100+\end{array}$} & $\begin{array}{r}0.16 \\
.47 \\
.45 \\
.17 \\
.09 \\
.02\end{array}$ & $\begin{array}{r}11.8 \\
34.6 \\
33.1 \\
12.5 \\
6.6 \\
1.5\end{array}$ \\
\hline & & & & 8.86 & 100.1 & & & 1.36 & 100.1 \\
\hline \multirow[t]{2}{*}{ Do............ } & \multirow[t]{2}{*}{ G-2A... } & \multirow[t]{2}{*}{9.45} & \multirow[t]{2}{*}{$\begin{array}{c}20 \\
40 \\
60 \\
80 \\
100 \\
100+\end{array}$} & $\begin{array}{l}.60 \\
4.73 \\
2.90 \\
.79 \\
.45 \\
.11\end{array}$ & $\begin{array}{r}6.3 \\
49.4 \\
30.3 \\
8.2 \\
4.7 \\
1.1\end{array}$ & \multirow[t]{2}{*}{.59} & \multirow[t]{2}{*}{$\begin{array}{c}20 \\
40 \\
60 \\
80 \\
100 \\
100+\end{array}$} & $\begin{array}{l}.12 \\
.17 \\
.15 \\
.09 \\
.07 \\
.04\end{array}$ & $\begin{array}{r}18.8 \\
26.5 \\
23.4 \\
14.1 \\
10.9 \\
6.3\end{array}$ \\
\hline & & & & 9.58 & 100.0 & & & .64 & 100.0 \\
\hline \multirow[t]{2}{*}{ Woodstown....... } & \multirow[t]{2}{*}{ G-3A... } & \multirow[t]{2}{*}{8.09} & \multirow[t]{2}{*}{$\begin{array}{c}20 \\
40 \\
60 \\
80 \\
100 \\
100+\end{array}$} & $\begin{array}{r}.35 \\
3.06 \\
2.49 \\
.94 \\
.75 \\
.64\end{array}$ & $\begin{array}{r}4.3 \\
37.2 \\
30.3 \\
11.4 \\
9.1 \\
7.7\end{array}$ & \multirow[t]{2}{*}{1.97} & \multirow[t]{2}{*}{$\begin{array}{c}20 \\
40 \\
60 \\
80 \\
100 \\
100+\end{array}$} & $\begin{array}{l}.20 \\
.29 \\
.67 \\
.32 \\
.30 \\
.25\end{array}$ & $\begin{array}{r}9.9 \\
14.3 \\
33.0 \\
15.8 \\
14.8 \\
12.3\end{array}$ \\
\hline & & & & 8.23 & 100.0 & & & 2.03 & 100.1 \\
\hline \multirow[t]{2}{*}{ Do............. } & \multirow[t]{2}{*}{ G-4A... } & \multirow[t]{2}{*}{9.60} & \multirow[t]{2}{*}{$\begin{array}{c}20 \\
40 \\
60 \\
80 \\
100 \\
100+\end{array}$} & $\begin{array}{r}.19 \\
3.77 \\
3.53 \\
1.00 \\
.69 \\
.46\end{array}$ & $\begin{array}{r}1.9 \\
39.1 \\
36.6 \\
10.4 \\
7.2 \\
4.8\end{array}$ & \multirow[t]{2}{*}{.39} & \multirow[t]{2}{*}{$\begin{array}{c}20^{\prime} \\
40 \\
60 \\
80 \\
100 \\
100+\end{array}$} & $\begin{array}{l}.03 \\
.07 \\
.11 \\
.06 \\
.07 \\
.08\end{array}$ & $\begin{array}{r}7.1 \\
16.7 \\
26.2 \\
14.3 \\
16.7 \\
19.0\end{array}$ \\
\hline & & & & 9.64 & 100.0 & & & .42 & 100.0 \\
\hline \multirow[t]{2}{*}{ Do............. } & \multirow[t]{2}{*}{ G-5A... } & \multirow[t]{2}{*}{9.30} & \multirow[t]{2}{*}{$\begin{array}{c}20 \\
40 \\
60 \\
80 \\
100 \\
100+\end{array}$} & $\begin{array}{r}.34 \\
4.55 \\
2.90 \\
.82 \\
.57 \\
.19\end{array}$ & $\begin{array}{r}3.6 \\
48.6 \\
30.9 \\
8.8 \\
6.1 \\
2.0\end{array}$ & .75 & $\begin{array}{c}20 \\
40 \\
60 \\
80 \\
100 \\
100+\end{array}$ & $\begin{array}{l}.08 \\
.16 . \\
.27 \\
.10 \\
.10 \\
.09\end{array}$ & $\begin{array}{l}10.0 \\
20.0 \\
33.8 \\
12.5 \\
12.5 \\
11.2\end{array}$ \\
\hline & & & & 9.37 & 100.0 & & & .80 & 100.0 \\
\hline Sewell... & $G-6 A \ldots$ & 8.27 & $\begin{array}{c}20 \\
40 \\
60 \\
80 \\
100 \\
100+\end{array}$ & $\begin{array}{r}.37 \\
2.27 \\
3.10 \\
1.04 \\
.95 \\
.65\end{array}$ & $\begin{array}{r}4.4 \\
27.1 \\
37.0 \\
12.4 \\
11.3 \\
7.8\end{array}$ & 1.78 & $\begin{array}{c}20 \\
40 \\
60 \\
80 \\
100 \\
100+\end{array}$ & $\begin{array}{l}.08 \\
.16 \\
.48 \\
.35 \\
.49 \\
.26\end{array}$ & $\begin{array}{r}4.4 \\
8.8 \\
26.4 \\
19.2 \\
26.9 \\
14.3\end{array}$ \\
\hline & & & & 8.38 & 100.0 & & & 1.82 & 100.0 \\
\hline Do........... & G-7A... & 9.77 & $\begin{array}{c}20 \\
40 \\
60 \\
80 \\
\cdot 100 \\
100+\end{array}$ & $\begin{array}{r}.09 \\
3.25 \\
4.02 \\
1.05 \\
.80 \\
.63\end{array}$ & $\begin{array}{r}.9 \\
33.0 \\
40.9 \\
10.7 \\
8.1 \\
6.4\end{array}$ & .30 & $\begin{array}{c}20 \\
40 \\
60 \\
80 \\
100 \\
100+\end{array}$ & $\begin{array}{l}.04 \\
.06 \\
.09 \\
.04 \\
.05 \\
.10\end{array}$ & $\begin{array}{l}10.5 \\
15.8 \\
23.7 \\
10.5 \\
13.2 \\
26.3\end{array}$ \\
\hline & & & & 9.84 & 100.0 & v & & .38 & 100.0 \\
\hline
\end{tabular}


Size of grains of glauconite, quartz, etc., in washed greensand-Continued.

\begin{tabular}{|c|c|c|c|c|c|c|c|c|c|}
\hline \multirow{3}{*}{ Locality. } & \multirow{3}{*}{$\begin{array}{l}\text { Sample } \\
\text { No. }\end{array}$} & \multicolumn{4}{|c|}{ Glauconite, etc. (C). } & \multicolumn{4}{|c|}{ Quartz, etc. (D). } \\
\hline & & \multirow{2}{*}{$\begin{array}{l}\text { Quan- } \\
\text { tity in } \\
\text { sample } \\
\text { (grams). }\end{array}$} & \multicolumn{3}{|c|}{ Quantity held on sieves. } & \multirow{2}{*}{$\begin{array}{l}\text { Quan- } \\
\text { tity in } \\
\text { sample } \\
\text { (grams). }\end{array}$} & \multicolumn{3}{|c|}{ Quantity held on sieves. } \\
\hline & & & Mesh. & Grams. & Per cent. & & Mesh. & Grams. & Per cent. \\
\hline \multirow[t]{2}{*}{ Sewell ............. } & \multirow[t]{2}{*}{ G-8A... } & \multirow[t]{2}{*}{9.51} & \multirow[t]{2}{*}{$\begin{array}{c}20 \\
40 \\
60 \\
80 \\
100 \\
100+\end{array}$} & $\begin{array}{l}0.25 \\
4.72 \\
3.14 \\
.71 \\
.47 \\
.23\end{array}$ & $\begin{array}{r}2.6 \\
49.6 \\
32.9 \\
7.5 \\
4.9 \\
2.4\end{array}$ & \multirow[t]{2}{*}{0.55} & \multirow[t]{2}{*}{$\begin{array}{c}20 \\
40 \\
60 \\
80 \\
100 \\
100+\end{array}$} & $\begin{array}{l}0.14 \\
.24 \\
.14 \\
.02 \\
.02 \\
.02\end{array}$ & $\begin{array}{r}24.1 \\
41.4 \\
24.1 \\
3.4 \\
3.4 \\
3.4\end{array}$ \\
\hline & & & & 9.52 & 99.9 & & & .58 & 99.8 \\
\hline \multirow[t]{2}{*}{ Somerdale......... } & \multirow[t]{2}{*}{$G-9 A \ldots$} & \multirow[t]{2}{*}{9.32} & \multirow[t]{2}{*}{$\begin{array}{l}20 \\
40 \\
60 \\
80 \\
100 \\
100+\end{array}$} & $\begin{array}{r}.01 \\
1.21 \\
2.85 \\
1.42 \\
1.45 \\
2.30\end{array}$ & $\begin{array}{r}.1 \\
13.0 \\
30.8 \\
15.4 \\
15.7 \\
24.9\end{array}$ & \multirow[t]{2}{*}{.74} & \multirow[t]{2}{*}{$\begin{array}{c}20 \\
40 \\
60 \\
80 \\
100 \\
100+\end{array}$} & $\begin{array}{l}.04 \\
.09 \\
.08 \\
.04 \\
.07 \\
.40\end{array}$ & $\begin{array}{r}5.5 \\
12.5 \\
11.1 \\
5.5 \\
9.7 \\
55.5\end{array}$ \\
\hline & & & & 9.24 & 99.9 & & & .72 & 99.8 \\
\hline \multirow[t]{2}{*}{ Do........... } & \multirow[t]{2}{*}{ G-10A.. } & \multirow[t]{2}{*}{9.70} & \multirow[t]{2}{*}{$\begin{array}{c}20 \\
40 \\
60 \\
80 \\
100 \\
100+\end{array}$} & $\begin{array}{r}.17 \\
3.32 \\
4.00 \\
1.07 \\
.78 \\
.37\end{array}$ & $\begin{array}{r}1.8 \\
34.2 \\
41.2 \\
11.0 \\
8.0 \\
3.8\end{array}$ & \multirow[t]{2}{*}{.34} & \multirow[t]{2}{*}{$\begin{array}{c}20 \\
40 \\
60 \\
80 \\
100 \\
100+\end{array}$} & $\begin{array}{l}.05 \\
.12 \\
.07 \\
.02 \\
.04 \\
.04\end{array}$ & $\begin{array}{r}14.7 \\
35.3 \\
20.6 \\
5.9 \\
11.8 \\
11.8\end{array}$ \\
\hline & & & & 9.71 & 100.0 & & & .34 & 100.1 \\
\hline \multirow[t]{2}{*}{ Do............ } & \multirow[t]{2}{*}{ G-11A.. } & \multirow[t]{2}{*}{9.62} & \multirow[t]{2}{*}{$\begin{array}{c}20 \\
40 \\
60 \\
80 \\
100 \\
100+\end{array}$} & $\begin{array}{r}.05 \\
2.87 \\
3.22 \\
1.05 \\
.97 \\
1.38\end{array}$ & $\begin{array}{r}.5 \\
30.1 \\
33.8 \\
11.0 \\
10.2 \\
14.5\end{array}$ & \multirow[t]{2}{*}{.40} & \multirow[t]{2}{*}{$\begin{array}{c}20 \\
40 \\
60 \\
80 \\
100 \\
100+\end{array}$} & $\begin{array}{l}.01 \\
.05 \\
.03 \\
.02 \\
.02 \\
.26\end{array}$ & $\begin{array}{r}2.6 \\
12.8 \\
7.7 \\
5.1 \\
5.1 \\
66.6\end{array}$ \\
\hline & & & & 9.54 & 100.1 & & & .39 & 99.9 \\
\hline \multirow[t]{2}{*}{ Elmwood Road... } & \multirow[t]{2}{*}{ G-12A. . } & \multirow[t]{2}{*}{6.24} & $\begin{array}{c}20 \\
40 \\
60 \\
80 \\
100 \\
100+\end{array}$ & $\begin{array}{r}.55 \\
2.33 \\
1.69 \\
.67 \\
.53 \\
.42\end{array}$ & $\begin{array}{r}8.9 \\
37.6 \\
27.3 \\
10.8 \\
8.6 \\
6.8\end{array}$ & $\begin{array}{c}3.75 \\
.\end{array}$ & $\begin{array}{c}20 \\
40 \\
60 \\
80 \\
100 \\
100+\end{array}$ & $\begin{array}{r}.04 \\
.25 \\
1.17 \\
.86 \\
1.04 \\
.35\end{array}$ & $\begin{array}{r}1.1 \\
6.7 \\
31.5 \\
23.2 \\
28.0 \\
9.4\end{array}$ \\
\hline & & & & 6.19 & 100.0 & & & 3.71 & 99.9 \\
\hline Do..... & G-13A.. & 9.50 & $\begin{array}{c}20 \\
40 \\
60 \\
80 \\
100 \\
100+\end{array}$ & $\begin{array}{r}.50 \\
5.42 \\
2.97 \\
.39 \\
.15 \\
.02\end{array}$ & $\begin{array}{r}5.3 \\
57.4 \\
31.4 \\
4.1 \\
1.6 \\
.2\end{array}$ & .55 & $\begin{array}{c}20 \\
40 \\
60 \\
80 \\
100 \\
100+\end{array}$ & $\begin{array}{l}.19 \\
.14 \\
.15 \\
.05 \\
.04 \\
.02\end{array}$ & $\begin{array}{r}32.2 \\
23.7 \\
25.4 \\
8.5 \\
6.8 \\
3.4\end{array}$ \\
\hline & & & & 9.45 & 100.0 & & & .59 & 100.0 \\
\hline Do. & G-14A. & 9.65 & $\begin{array}{c}20 \\
40 \\
60 \\
80 \\
100 \\
100+\end{array}$ & $\begin{array}{r}.07 \\
6.12 \\
2.50 \\
.46 \\
.27 \\
.29\end{array}$ & $\begin{array}{r}.7 \\
63.0 \\
26.0 \\
4.7 \\
2.8 \\
3.0\end{array}$ & .40 & $\begin{array}{c}20 \\
40 \\
60 \\
80 \\
100 \\
100+\end{array}$ & $\begin{array}{l}.10 \\
.04 \\
.01 \\
.02 \\
.02 \\
.20\end{array}$ & $\begin{array}{r}25.6 \\
10.2 \\
2.6 \\
5.1 \\
5.1 \\
51.3\end{array}$ \\
\hline & & & & 9.71 & 100.2 & & & .39 & 99.9 \\
\hline Pemberton... & G-15A. & 5.27 & $\begin{array}{c}20 \\
40 \\
60 \\
80 \\
100 \\
100+\end{array}$ & $\begin{array}{r}.09 \\
1.22 \\
1.69 \\
.87 \\
.80 \\
.62\end{array}$ & $\begin{array}{r}1.7 \\
23.0 \\
32.1 \\
16.4 \\
15.1 \\
11.7\end{array}$ & 4.79 & $\begin{array}{c}20 \\
40 \\
60 \\
80 \\
100 \\
100+\end{array}$ & $\begin{array}{r}.18 \\
.74 \\
.66 \\
.72 \\
.95 \\
1.55\end{array}$ & $\begin{array}{r}3.9 \\
15.4 \\
13.8 \\
15.0 \\
19.6 \\
32.3\end{array}$ \\
\hline & & & & 5. 29 & 100.0 & & & 4.80 & 100.0 \\
\hline
\end{tabular}


The glauconite particles range in diameter from more than 20-mesh to less than 100-mesh, but the greatest number by weight fall between 20 and 40 mesh, though many fall between 40 and 60 mesh. Below the last size the quantity of glauconite falls off rapidly, though a few samples, especially G-9A, have considerable material of the smaller sizes.

The quartz grains, too, fall chiefly between 20 and 60 mesh, but there is a large percentage also of the finest grains.

\section{SHAPES OF GRAINS.}

The largest glauconite grains, 20-mesh or more in diameter, show their form most clearly. Under the hand lens they appear irregular, botryoidal, or mammillary in general form, suggesting aggregates of rounded grains, rather than casts of foraminiferal shells, though some grains suggest such form. Many appear to be rounded nodules with irregular cracks of lighter color. The grains in general have a shiny surface and dark-green color. The 40 and 60 mesh grains show similar forms and markings but a greater degree of regularity, as if reduced by wear from larger grains. Some of the grains are elongate or curved and have a platy structure or cleavage. The smaller grains are subangular to rounded, though retaining to some extent the suggestion of earlier form and markings. They have evidently been much worn and represent, at least in part, material that has been transported and redeposited. Other grains, nonmagnetic, have seedlike or capsule form and measure $40 \mathrm{mesh}$ or less. These, tested qualitatively, give a strong reaction for phosphate. Typical glauconite grains, somewhat magnified, are shown in Plate IV (p. 6).

The quartz grains are generally irregular, angular, or subangular, though some of the larger grains (40 to 20 mesh) are rounded.

\section{SUMMMARY.}

Composite samples, so prepared as to represent the principal beds of commercial thickness at each of the localities drilled, were washed, and the residues were magnetically separated and sized. Some greensand was relatively free from clay or mud, but on the average it contained about 20 per cent of such material. Glauconite grains form nearly 92 per cent of two of the beds, but the general average is 73 per cent for the beds examined. The most common size for the glauconite grains is from 20 to 60 mesh. Their shapes are generally irregular and suggest mechanical aggregation.

\section{CHEMICAL ANALYSES OF GREENSAND.}

CHARACTER AND NUMBER OF ANALYSES.

The character and number of analyses and determinations made in the chemical laboratory of the United States Geological Survey in connection with the present investigation are shown below. The 
potash determinations were all made by the method described by Hicks and Bailey. ${ }^{65}$

Analyses and determinations of greensand, etc.

\begin{tabular}{|c|c|}
\hline Character of work. & $\begin{array}{l}\text { Number of } \\
\text { determina- } \\
\text { tions. }\end{array}$ \\
\hline 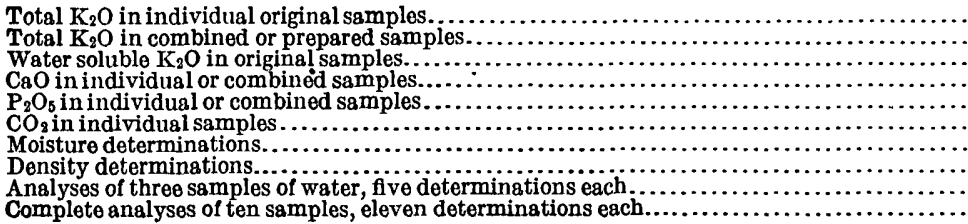 & $\begin{array}{r}128 \\
17 \\
18 \\
15 \\
13 \\
2 \\
6 \\
3 \\
15 \\
110\end{array}$ \\
\hline & 327 \\
\hline
\end{tabular}

The total potash content of the individual original samples has been given in the logs of the respective borings. It has furnished the basis of the computations and estimates already presented. The density and moisture content of the greensand have also been utilized in these computations and estimates. Some reference has also been made to the determinations of $\mathrm{CaO}, \mathrm{P}_{2} \mathrm{O}_{5}$, and $\mathrm{CO}_{2}$. Other features of the investigation are described below.

\section{COMPOSITION OF GREENSAND.}

Numerous analyses of greensand samples from different parts of New Jersey are given by Cook. ${ }^{06}$ Four of them, which relate to localities near those sampled in the present investigation, are given in the following table:

Analyses of greensand.

\begin{tabular}{|c|c|c|c|c|}
\hline & 1 & 2 & 3 & 4 \\
\hline \multirow{3}{*}{ 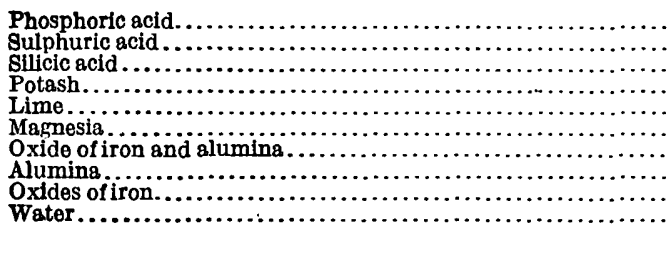 } & $\begin{array}{r}1.68 \\
.96 \\
55.93 \\
5.80 \\
1.64 \\
1.01 \\
24.41\end{array}$ & $\begin{array}{r}1.02 \\
.27 \\
50.23 \\
6.32 \\
1.40 \\
3.45\end{array}$ & $\begin{array}{r}2.69 \\
.26 \\
49.40 \\
6.31 \\
2.52 \\
3.25\end{array}$ & $\begin{array}{r}2.34 \\
.21 \\
50.00 \\
6.18 \\
1.57 \\
.60\end{array}$ \\
\hline & 8.84 & $\begin{array}{r}7.94 \\
20.14 \\
9.00\end{array}$ & $\begin{array}{r}8.90 \\
18.66 \\
7.55\end{array}$ & $\begin{array}{r}6.15 \\
24.32 \\
6.88\end{array}$ \\
\hline & 100.27 & 99.77 & 99.54 & 98.25 \\
\hline
\end{tabular}

1. "Upper marl bed" (Manasquan) from Joshua Forsyth's place near Pemberton; green marl, an average specimen. Cook, G. H., op. cit., p. 435.

2. "Middle marl bed" (Hornerstown), from the Pemberton Marl Co., sent by J. C. Gaskill as an average. Idem, p. 434.

3. "Middle marl bed" (Hornerstown), from pits of West Jersey Marl \& Transportation Co.; average of the whole bed dug. Idem, p. 437.

4. "Lower marl bed" (probably Hornerstown rather than Navesink) from farm of Jesse Lippincott, near Oldman's Creek, Gloucester County; and average of the green marl of this neighborhood. Idem p. 439.

${ }^{66}$ Hucks, W. B., and Bailey, R. K., Methods of analysis of greensand: U. S. Geol. Survey Bull. 660, pp. 51-58, 1918.

of Cook, G. H., The geology of New Jersey, pp. 417-441, 1868. 
Much time has elapsed since the publication of Cook's work, and there have been changes in methods of analysis, so that it was thought desirable as a check to make a few complete analyses of greensand samples taken in the present investigation. Four samples were accordingly selected, the analyses of which are given in the following table:

\section{Analyses of greensand.}

[R. K. Bailey, analyst. For organic matter see p. 130.]

\begin{tabular}{|c|c|c|c|c|c|c|c|c|c|}
\hline & M-119 & $M I-99$ & $M-52$ & $\mathrm{M}-15$ & $\cdot$. & $\mathrm{M}^{\circ}-119$ & M-99 & $\mathrm{M}-52$ & $\mathrm{M}-15$ \\
\hline \multirow{2}{*}{ 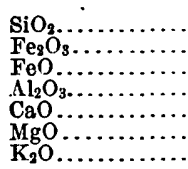 } & \multirow{2}{*}{\begin{tabular}{r|}
68.90 \\
8.91 \\
1.52 \\
3.52 \\
2.10 \\
1.90 \\
3.56
\end{tabular}} & \multirow{2}{*}{$\begin{array}{r}50.74 \\
17.36 \\
3.34 \\
1.93 \\
2.86 \\
3.76 \\
6.68\end{array}$} & \multirow{2}{*}{$\begin{array}{r}51.83 \\
17.15 \\
2.93 \\
6.23 \\
.52 \\
3.66 \\
6.60\end{array}$} & \multirow{2}{*}{$\begin{array}{r}50.32 \\
18.38 \\
3.02 \\
7.53 \\
.65 \\
3.82 \\
7.89\end{array}$} & \multirow[t]{2}{*}{$\begin{array}{l}\mathrm{Na}_{2} \mathrm{O} \ldots \ldots \ldots \ldots \ldots \\
\mathrm{CO}_{2} \ldots \ldots \ldots \ldots \ldots \\
\mathrm{P}_{2} \mathrm{O}_{5} \ldots \ldots \ldots \ldots \ldots \\
\mathrm{H}_{2} \mathrm{O} \ldots \ldots \ldots \ldots \ldots\end{array}$} & $\begin{array}{l}0.82 \\
1.00 \\
1.05 \\
7.68 \\
\end{array}$ & $\begin{array}{l}1.53 \\
.88 \\
1.79 \\
9.08\end{array}$ & $\begin{array}{r}0.76 \\
.36 \\
.31 \\
9.98\end{array}$ & $\begin{array}{r}0.22 \\
.15 \\
.34 \\
\text { S. } 53 \\
\end{array}$ \\
\hline & & & & & & 1.00 .96 & 99.95 & 100.12 & 100.89 \\
\hline
\end{tabular}

M-119. Manasquan marl from hole 17, locality 96, between Birmingham and Pemberton. (See p. 86.)

M-99. Hornerstown marl from hole 15, locality 62, Elmwood Road. (See p. 70.)

M-52. Hornerstown marl from hole 10, locality 35 , Sewell. (See p. 49.)

M-15. Hornerstown marl from hole 6, locality 13, Woodstown. (See p. 32.)

Although the localities from which the Cook samples were taken are not definitely known the respective materials represented by the two sets of analyses may perhaps be regarded as fairly comparable. Certain differences, however, deserve mention.

The potash content of Cook's samples 2, 3, and 4 seems at first sight to agree fairly well with that of samples M-99, M-52 and M-15, though it is somewhat lower. It does not appear, however, that $\mathrm{Na}_{2} \mathrm{O}$ was separately determined in the Cook samples. This substance is therefore probably included in the figure for potash. Further, as pointed out by Hicks and Bailey, ${ }^{67}$ the methods employed in the analyses cited by Cook would tend to give too low a value for the potash. Thus the semblance of agreement in potash content in the two sets of analyses is accidental.

The silica content of the six samples cited in the preceding paragraph is fairly accordant, as is also the content of the combined oxides of iron. The other constituents show a greater degree of variation.

Sample 1 of the Cook set and sample M-119, both of which represent Manasquan marl, show considerably less potash than the other samples, though sample 1 is apparently of better grade than sample M-119, as shown by its lower content of silica as well as by its higher indicated content of potash. The high silica content of both these samples is probably due to a greater admixture of quartz grains in the marl.

The percentages of $\mathrm{CaO}, \mathrm{P}_{2} \mathrm{O}_{5}$, and $\mathrm{CO}_{2}$ indicate that only small quantities of the carbonate and phosphate of lime are present in the

${ }^{07}$ Hicks, W. B., and Bailey, R. K., op. cit., p. 52. 
better-grade marls. Some of the $\mathrm{P}_{2} \mathrm{O}_{5}$ is doubtless combined with iron instead of with lime, for the mineral vivianite occurs at a number of the localities sampled.

Some of the iron is probably present in the form of sulphides or sulphates, as indicated by the sulphuric acid of the Cook samples and by the "irony water" noted at many wells.

\section{COMPOSITION OF PRODUCTS OF WET SEPARATION.}

In the section on mechanical analyses of greensand (p. 117) it is suggested that much of the claylike material so abundant in some beds of greensand is really composed of finely comminuted glauconite grains. Four analyses were therefore made for the purpose of comparing the chemical composition of the products of wet separation and of unaltered greensand. The samples used were some of those prepared for mechanical analysis. (See p. 118.) Each represents high-grade Hornerstown marl. The chemical analyses are given in the following table:

Composition of products of wet separation.

[R. K. Bailey, analyst.]

\begin{tabular}{|c|c|c|c|c|c|c|c|c|c|}
\hline & $\mid \begin{array}{c}\text { G-7A } \\
\text { (coarse } \\
\text { residue } \\
\text { Sewell). }\end{array}$ & $\begin{array}{c}\text { G-7B } \\
\text { (fine } \\
\text { wash- } \\
\text { ings } \\
\text { Sewell). }\end{array}$ & $\begin{array}{l}\text { G-13A } \\
\text { (coarse } \\
\text { residue, } \\
\text { Elm- } \\
\text { wood } \\
\text { Road). }\end{array}$ & $\begin{array}{c}\text { G-13B } \\
\text { (fine } \\
\text { wash- } \\
\text { ings, } \\
\text { Elm- } \\
\text { wood } \\
\text { Road). }\end{array}$ & & $\mid \begin{array}{c}\text { G-7A } \\
\text { (coarse } \\
\text { residue, } \\
\text { Sewell). }\end{array}$ & $\begin{array}{l}\text { G-7B } \\
\text { (fine } \\
\text { wash- } \\
\text { ings } \\
\text { Sewell). }\end{array}$ & $\begin{array}{c}\text { G-13A } \\
\text { (coarse } \\
\text { residue, } \\
\text { Elm- } \\
\text { wood } \\
\text { Road). }\end{array}$ & $\begin{array}{l}\text { G-13B } \\
\text { (fine } \\
\text { wash- } \\
\text { ings, } \\
\text { Elm- } \\
\text { wood } \\
\text { Road). }\end{array}$ \\
\hline \multirow{2}{*}{$\begin{array}{l}\mathrm{SiO}_{2} \ldots \ldots \ldots \ldots \\
\mathrm{Fe}_{2} \mathrm{O}_{3} \ldots \ldots \ldots \ldots \ldots \ldots \\
\mathrm{FeO}_{\ldots} \ldots \ldots \ldots \ldots \ldots \\
\mathrm{Al}_{2} \mathrm{O}_{3} \ldots \ldots \ldots \ldots \ldots \ldots \\
\mathrm{CaO}^{2} \ldots \ldots \ldots \ldots \ldots \ldots \\
\mathrm{MgO}_{2} \ldots \ldots \ldots \ldots \ldots \ldots\end{array}$} & \multirow{2}{*}{$\begin{array}{r}50.38 \\
18.69 \\
2.84 \\
7.83 \\
.37 \\
3.54 \\
7.85\end{array}$} & \multirow{2}{*}{$\begin{array}{r}49.30 \\
16.33 \\
2.61 \\
8.92 \\
.72 \\
3.44 \\
6.74\end{array}$} & \multirow{2}{*}{$\begin{array}{r}49.50 \\
18.27 \\
3.03 \\
6.52 \\
1.77 \\
3.78 \\
7.37\end{array}$} & \multirow{2}{*}{$\begin{array}{r}43.70 \\
15.50 \\
2.54 \\
11.10 \\
3.43 \\
2.99 \\
5.73\end{array}$} & \multirow[t]{2}{*}{$\begin{array}{l}\mathrm{Na}_{2} \mathrm{O} \ldots \ldots \ldots \ldots \\
\mathrm{CO}_{2} \ldots \ldots \ldots \ldots \ldots \ldots \\
\mathrm{P}_{3} \mathrm{O}_{5} \ldots \ldots \ldots \ldots \ldots \ldots \ldots \ldots \\
\mathrm{H}_{2} \mathrm{O} \ldots \ldots \ldots \ldots \ldots \ldots\end{array}$} & $\begin{array}{r}0.30 \\
.10 \\
.28 \\
8.70 \\
\end{array}$ & $\begin{array}{l}0.36 \\
2.48 \\
.64 \\
9.22 \\
\end{array}$ & $\begin{array}{r}0.26 \\
.30 \\
1.09 \\
8.98 \\
\end{array}$ & $\begin{array}{l}1.15 \\
4.04 \\
(a) \\
10.80 \\
\end{array}$ \\
\hline & & & & & & 100.88 & 100.76 & 100.87 & 100.98 \\
\hline
\end{tabular}

a No material left for determination of $\mathrm{P}_{2} \mathrm{O}_{6}$.

These analyses appear to justify the view that the fine or claylike constituents of the greensand marl have practically the same composition as the coarser constituents and that much of the fine material is finely. comminuted or amorphous glauconite. When these samples are compared with each other or with samples M-99, M-52, and M-15 of the previous table certain variations appear, but the quantities of the respective constituents are of the same order.

\section{POTASH CONTENT OF THE FINES.}

Although it was impracticable to make extended analyses of all the samples of fines obtained by washing (see p. 118), the potash content of each was determined because of its possible bearing on the treatment of the marl in commercial operations. If the fines should prove decidedly lower in potash content than either the 
coarser residues or the unaltered marl it might pay to wash the marl before extracting the potash. In the preceding table the potash content of the fines is compared with that of the coarser residues. In the following table the potash content of the fines is compared with the average potash content of the unaltered greensand. (See p. 104.) The discrepancy in thicknesses given for the beds in the two tables cited is due to a revision of stratigraphic data after the mechanical analyses were completed. The beds from which the fines were taken correspond in a general way, however, to those for which the average potash content is given.

Potash content of fines and of unaltered greensand in per cent..

[R. K. Bailey, analyst.]

\begin{tabular}{|c|c|c|c|c|c|c|c|c|c|}
\hline \multirow{3}{*}{ Locality. } & \multicolumn{3}{|c|}{ Gray marl. } & \multicolumn{3}{|c|}{ Green marl. } & \multicolumn{3}{|c|}{ Chocolate marl. } \\
\hline & \multirow{2}{*}{$\begin{array}{c}\begin{array}{c}\text { Unal- } \\
\text { tered. }\end{array} \\
\mathrm{K}_{2} \mathrm{O} .\end{array}$} & \multicolumn{2}{|c|}{ Fines. } & \multirow{2}{*}{ $\frac{\begin{array}{c}\text { Unal- } \\
\text { tered. }\end{array}}{\mathrm{K}_{2} \mathrm{O} .}$} & \multicolumn{2}{|c|}{ Fines. } & \multirow{2}{*}{$\frac{\begin{array}{c}\text { Unal- } \\
\text { tered. }\end{array}}{\mathrm{K}_{2} \mathrm{O} .}$} & \multicolumn{2}{|c|}{ Fines. } \\
\hline & & $\begin{array}{c}\text { Sample } \\
\text { No. }\end{array}$ & $\mathrm{K}_{8} \mathrm{O}$ & & $\begin{array}{c}\text { Sample } \\
\text { No. }\end{array}$ & $\mathrm{K}_{2} \mathrm{O}$ & & $\begin{array}{c}\text { Sample } \\
\text { No. }\end{array}$ & $\mathrm{K}_{2} \mathrm{O}$ \\
\hline 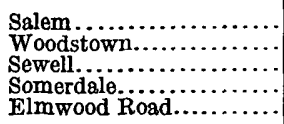 & $\begin{array}{c}6.19 \\
6.12 \\
6.09 \\
\ldots .01\end{array}$ & $\begin{array}{l}G-1 B \\
G-3 B \\
G-6 B \\
G-9 B \\
G-12 B\end{array}$ & $\begin{array}{l}4.73 \\
5.27 \\
6.20 \\
6.23 \\
4.55\end{array}$ & $\begin{array}{l}7.19 \\
7.58 \\
7.52 \\
7.35 \\
7.26\end{array}$ & $\begin{array}{l}G-2 B \\
G-4 B \\
G-7 B \\
G-10 B \\
G-13 B\end{array}$ & $\begin{array}{l}6.47 \\
7.04 \\
6.74 \\
7.26 \\
5.73\end{array}$ & $\begin{array}{l}\because 6.69 \\
5.99 \\
6.32 \\
6.32\end{array}$ & $\begin{array}{l}G-5 B \\
G-8 B \\
G-11 B \\
G-14 B\end{array}$ & $\begin{array}{l}\dddot{5} .16 \\
4.81 \\
5.50 \\
3.14\end{array}$ \\
\hline
\end{tabular}

For the Manasquan marl in the Birmingham-Pemberton area the average of samples M-119, 121, 123, 124, and 125 , weighted according to the thickness represented by each sample, was 3.7 per cent of potash, and the fines (sample G-15B) showed 2.89 per cent.

In general the potash content of the fines, as shown in the above table, runs from about 0.1 to 1.5 per cent lower than in the unaltered greensand. At Sewell the fines of the gray marl contain 0.11 per cent more potash than the unaltered marl, but at Elmwood Road the fines of the chocolate marl contain 3.18 per cent less potash than the unaltered marl. As indicated in the table on page 118, the fines of representative samples from all the districts examined average 19.5 per cent of the unaltered marl.

Concentration of the marl by washing would undoubtedly increase the proportion of potash in the resulting residues. This gain would be offset, however, by a loss of potash in the fines so nearly equal that the expense of washing the material would not be justified. 


\section{COMPOSITION OF GIAUCONITE.}

Cayeux ${ }^{68}$ cites a group of analyses showing the chemical composition of actual glauconite. The samples analyzed were all of recent material, mostly taken by the Challenger expedition. The analyses are presented in the following table.

Chemical composition of recent glauconite.

\begin{tabular}{|c|c|c|c|c|c|c|c|}
\hline & 1 & 2 & 3 & 4 & 5 & 6 & 7 \\
\hline \multirow[t]{2}{*}{ 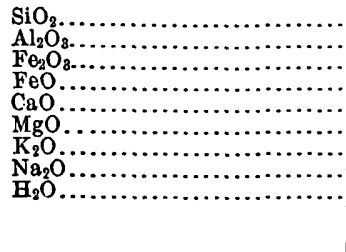 } & $\begin{array}{r}56.62 \\
12.54 \\
15.63 \\
1.18 \\
1.69 \\
2.49 \\
2.52 \\
.90 \\
6.84\end{array}$ & $\begin{array}{r}50.85 \\
8.92 \\
24.40 \\
1.66 \\
1.26 \\
3.13 \\
4.21 \\
.25 \\
\mathbf{5 . 5 5}\end{array}$ & $\begin{array}{r}51.80 \\
8.67 \\
24.21 \\
1.54 \\
1.27 \\
3.04 \\
3.86 \\
.25 \\
5.68\end{array}$ & $\begin{array}{r}55.17 \\
8.12 \\
21.59 \\
1.95 \\
1.34 \\
2.83 \\
3.36 \\
.27 \\
5.76\end{array}$ & $\begin{array}{r}27.74 \\
13.02 \\
39.93 \\
1.76 \\
1.19 \\
4.62 \\
0.95 \\
0.62 \\
10.85\end{array}$ & $\begin{array}{r}46.90 \\
4.06 \\
27.09 \\
3.60 \\
.20 \\
.70 \\
6.16 \\
1.28 \\
9.25\end{array}$ & $\begin{array}{r}47.46 \\
1.53 \\
30.83 \\
3.10 \\
7.91 \\
7.76 \\
7.00\end{array}$ \\
\hline & 100.41 & 100.23 & 100.32 & 100.39 & 100.68 & 99.24 & 100.09 \\
\hline
\end{tabular}

1-5. From Challenger reports.

6. Agulhas Bank, Indian Ocean. Gümbel, C.W., K. bayer. Akad. Wiss. Sitzungsber., vol. 16, p. 417, 1886.

7. Material from Challenger offlce, described by L. W. Collet (Les dépôts marins: Encyclopédie scientifique, p. 167, Paris, 1908) as "the purest specimen of actual glauconite which has ever been found."

The noteworthy features of these analyses are the relatively high percentage of ferric iron as compared with ferrous iron, the relatively high alumina content, and the low or moderate potash content.

Cayeux also cites a list of 23 analyses of glauconite from older sedimentary formations and shows, following other investigators, that these older glauconites, though still ferric, have greater percentages of ferrous iron than the recent types. The analyses also show a considerable increase in the amount of potash and in some at least a diminution in the amount of alumina. Collet ${ }^{8 \theta}$ remarks that "the glauconite which is forming to-day on the bottom of the sea is not the glauconite of sedimentary rocks, which certainly has undergone transformations that must be studied to understand the genesis of this interesting mineral." These transformations doubtless include the continuation of the process that he terms "glauconitization," to which further reference is made on page 140 .

A group of analyses of glauconite from sedimentary rocks, some of which are identical with those given by Cayeux, are cited by

es Cayeux, Lucien, Introduction à l'étude pétrographique des roches sédimentaires: Mém. carte géol. France, pp. 242-244, Paris, 1916.

Collet, L. W., op. cit., p. 168. 
Dana. ${ }^{70}$ Some of these, together with analyses of material collected in the present investigation, are given in the following table:

Chemical composition of guauconite from older sedimentary deposits.

\begin{tabular}{|c|c|c|c|c|c|c|c|c|c|}
\hline & 1 & 2 & 3 & 4 & 5 & 6 & 7 & $\mathrm{G}-7 \mathrm{Ca}$ & $\mathrm{G}-13 \mathrm{C} a$ \\
\hline 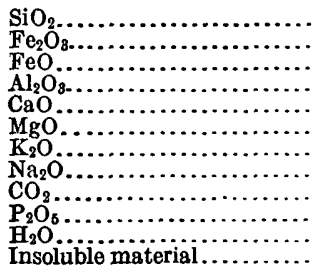 & $\begin{array}{r}49.42 \\
16.01 \\
3.00 \\
10.23 \\
.31 \\
3.78 \\
7.91 \\
.26 \\
\ldots . . . . \\
. .08 \\
.80\end{array}$ & $\begin{array}{r}51.24 \\
13.44 \\
3.06 \\
12.22 \\
.10 \\
3.93 \\
7.50 \\
.31 \\
\ldots \ldots . . \\
8.20 \\
.\end{array}$ & \begin{tabular}{r}
49.76 \\
16.00 \\
3.77 \\
8.18 \\
.41 \\
3.97 \\
7.57 \\
.52 \\
\hdashline .7. \\
9.82
\end{tabular} & 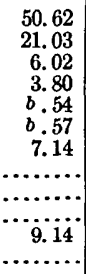 & $\begin{array}{r}50.42 \\
19.90 \\
5.96 \\
4.79 \\
3.21 \\
2.28 \\
7.87 \\
.21 \\
\cdots . . . \\
5.28\end{array}$ & $\begin{array}{r}46.91 \\
23.06 \\
2.64 \\
7.04 \\
2.95 \\
4.40 \\
7.31 \\
.91 \\
\ldots . . . \\
4.71\end{array}$ & $\begin{array}{r}49.09 \\
10.56 \\
3.06 \\
15.21 \\
.55 \\
2.65 \\
6.05 \\
1.21 \\
\ldots . \ldots . . \\
\cdots \\
11.64\end{array}$ & $\begin{array}{r}50.58 \\
19.50 \\
2.96 \\
6.72 \\
.34 \\
4.10 \\
8.26 \\
.04 \\
.30 \\
.27 \\
7.76\end{array}$ & $\begin{array}{r}49.47 \\
19.46 \\
3.36 \\
5.59 \\
.60 \\
3.96 \\
8.04 \\
.16 \\
.56 \\
1.06 \\
8.54\end{array}$ \\
\hline & 99.80 & 100.00 & 100.00 & 99.86 & 99.92 & 99.93 & 100.02 & 100.83 & 100.80 \\
\hline
\end{tabular}

a For organic matter see p. 130.

b Carbonates.

1. Swir River, Russia. Kupffer, A., Jahresb. Chemie, 1870, p. 1307.

2. Ontiks, Russia. Kupffer, A., idem.

3. Grodno Valley, Russia. Kupffer, A., idem.

4. Havre, France. Haushofer, K., Jour. prakt. Chemie, vol. 102, p. 38, 1866.

5. Antwerp, Belgium. Dewalque, F. Soc. géol. Belgique Annales, vol. 2, p. 3, 1875.

6. Gozzo Lsland, Mediterranean Sea. Bamberger, E., Min. pet. Mitt., 1877, p. 271.

7. Ashgrove, near Elgin, Scotland. Heddle, M. F., Roy. Soc. Edinburgh Trans., vol. 29, p. $79,1879$.

G-7C. Sewell, N. J., Hornerstown marl, glauconite grains separated magnetically from the residues of washed greensand. (See pp. 118-119.)

G-13C. Elmwood Road, N. J., Hornerstown marl, glauconite grains separated magnetically from the residues of washed greensand. (See pp. 118-119.)

The magnetic separation in the last two samples was very clear, so that these samples represent material as nearly pure as it seems possible to get by the method given. The potash content is distinctly higher than that of the other samples cited and is probably as high as could be expected from most New Jersey material. These analyses may therefore serve as a further check on the analyses of material from Eatontown given on page 97 . By comparison with the unaltered green marl from Sewell and from Elmwood Road (see p. 104), from which these samples were respectively derived, it appears that by washing and magnetic separation the potash content of the concentrate thus formed was increased about 0.7 per cent.

The above table shows the general range and variety of composition of the older glauconites. By comparison of these analyses with those of greensand given above and with the potash content of the samples taken in the several borings it will be seen that much of the New Jersey greensand is very nearly pure glauconite. Further discussion of the nature and origin of glauconite is given on pages 138-142.

\section{WATER-SOLUBIE POTASH.}

As the water solubility of potash in greensand has an important bearing on the use of that material as fertilizer or as an ingredient of prepared fertilizers, a number of analyses were made to determine

\footnotetext{
70 Dana, J. D. and E. S., System of mineralogy, 6th ed., p. 463, 1892.
} 
the amount of soluble potash in selected representative samples. The method employed was that given in Bulletin 107 of the Association of Official Agricultural Chemists. The following table shows both the total potash and the water-soluble potash of the samples:

Total and water-soluble potash.in greensand.

[R. K. Bailey and E. T. Erickson, analysts.]

\begin{tabular}{|c|c|c|c|}
\hline \multirow{2}{*}{ Sample No. } & \multirow{2}{*}{ Locality. } & \multicolumn{2}{|c|}{$\mathrm{K}_{2} \mathrm{O}$ (per cent). } \\
\hline & & Total. & Soluble. \\
\hline 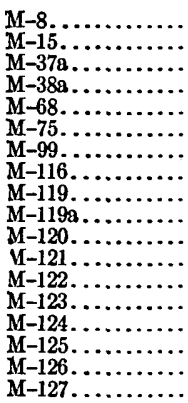 & 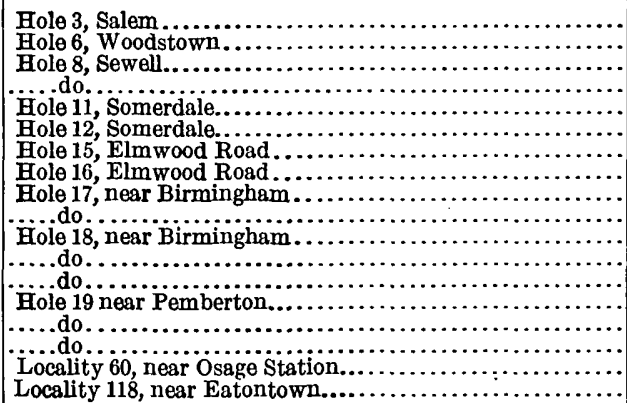 & $\begin{array}{l}7.72 \\
7.88 \\
7.62 \\
6.18 \\
7.58 \\
7.32 \\
6.68 \\
6.36 \\
3.61 \\
3.63 \\
3.27 \\
2.75 \\
1.83 \\
4.29 \\
2.99 \\
4.61 \\
7.17 \\
7.09\end{array}$ & $\begin{array}{r}0.06 \\
.04 \\
\text { Trace. } \\
\text { Trace. } \\
.02 \\
.02 \\
.04 \\
.06 \\
\text { Faint trace. } \\
\text { Trace. } \\
\text { None. } \\
\text { None. } \\
\text { None. } \\
\text { Trace. } \\
\text { Trace. } \\
\text { Trace. } \\
\text { Trace. } \\
\text { Trace. }\end{array}$ \\
\hline
\end{tabular}

From the above table it appears that the water-soluble potash content of greensand is very low. The greensand is thus generally regarded as unsuited for use in prepared fertilizers, though some of it has been used in fertilizer as a filler.

\section{ACID SOLUBILITY.}

No special tests of the solubility of greensand in acids were made, but greensand is said to be directly and slowly soluble in dilute acids (sulphuric, hydrochloric, or even acetic), so that the potash becomes available.

\section{SOLUBILITY AND AVAILABILITY.}

Although the availability of fertilizer ingredients is generally supposed to depend on their solubility, greensand appears to ofler an exception to this rule. Its wide and beneficial use as a fertilizer in former years lends strong probability to the idea that its potash, though practically insoluble in water, is actually available for plant growth. Possibly the weak acids present in some soils or the local reaction between the greensand and the root activity of certain plants may bring about this condition. Experiments of True and Geise, of the United States Department of Agriculture, on the availability of potash in greensand have been described on pages 113-115. 


\section{ORGANIC MATTER.}

In the analyses reported on pages 124 and 128 organic matter was inadvertently omitted. For the sake of completeness this was later determined for the four samples of greensand and for two of the magnetically separated. samples of glauconite. In the determinations, which were made by E. T. Erickson in the laboratory of the United States Geological Survey, the sample was treated initially with dilute sulphuric acid with some boiling to eliminate inorganic carbon dioxide. Possibly a slight and nègligible amount of organic matter escaped in this treatment. The residue was then heated nearly to the boiling point of an aggregate of about 50 per cent $\mathrm{H}_{2} \mathrm{SO}_{4}$ and 10 per cent $\mathrm{Cr}_{2} \mathrm{O}_{3}$. The following determinations of organic carbon were calculated from the carbon dioxide recovered from this procedure:

Organic carbon in samples of greensand and glauconit from New Jersey.

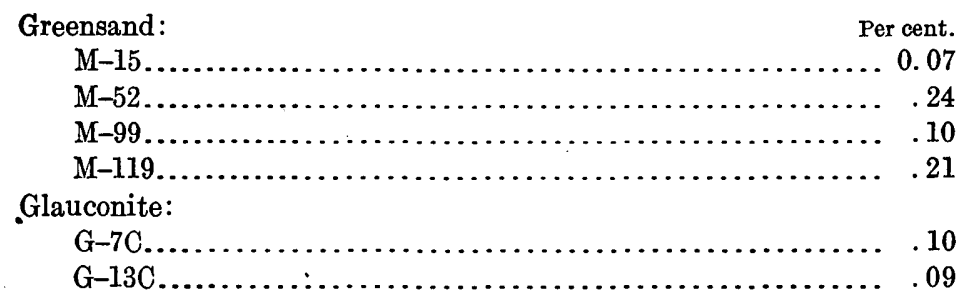

Mr. Erickson states that for stabilized organic matter-that is, organic matter not of recent origin-the hydrogen content may be considered as considerably less than the corresponding amounts of carbon and very likely not over one-fifth of that of the organic carbon. The total organic matter for each sample is therefore, roughly, not much greater than the quantity of carbon indicated for it-probably not more than one-fifth greater.

It is worthy of note that for two of the greensand samples the quantity of organic matter present is practically identical with that of the two samples of pure glauconite and that for the other two samples of greensand the quantity of organic matter is still very small.

The bearing of organic matter upon the formation of glauconite is discussed on pages $140-141$.

\section{PHOSPHORIC ACHD AND ITME.}

As the investigation dealt chiefly with potash, little attention was devoted to phosphoric acid and lime, but some analyses were made as a check on earlier determinations and because of the agricultural 
importance of these substances in the marl. Cook $^{71}$ emphasized the importance of the phosphoric acid in these words:

Phosphoric acid is the most valuable constituent of the whole. Indeed, it may be asserted as a general truth, that the greensand marls may be valued just in proportion to the percentage of this acid they contain.

In that day the effect of potash on plant growth was just beginning to be realized. In the light of the experiments of True and Geise it now seems probable that the potash in the marl is sufficiently available to have agricultural importance at least equal to that of the phosphoric acid.

The average phosphoric acid content of New Jersey greensand marls as shown by 130 analyses given by Cook $^{72}$ is 1.78 per cent. Similarly the average lime content derived from 105 of Cook's analyses is 2.25 per cent. The highest individual percentage of phosphoric acid cited by him was 6.87 in a sample from the upper marl (Manasquan) from Poplar. The highest percentage of lime (not counting that reported as carbonate) was $\mathbf{1 5 . 1 9}$ in a sample from the lower bed (Navesink) from Holmdel.

Fairly recent analyses cited on pages 95,96 , and 98 give 0.907 per cent of phosphoric acid as the average of ten samples of Navesink marl from the Marlboro district, 0.96 per cent as the average of three samples of Hornerstown marl from Freehold, and 1.16 per cent as the average of seven samples of Manasquan marl from Farmingdale.

Analyses of three composite samples of Manasquan marl from the Birmingham-Pemberton district, made in connection with the present investigation and given on page 88 , show from 1.37 to 3.58 per cent of phosphoric acid and from 1.53 to 3.86 per cent of lime. Additional analyses of selected individual or composite samples from the Hornerstown and Navesink marls are given in the following table:

Lime and phosphoric acid in selected samples of marl.

[R. K. Bailey and E. T. Erickson, analysts.]

\begin{tabular}{|c|c|c|c|c|}
\hline Sample No. & Locality. & Formation. & $\mathrm{CaO}$ & $\mathrm{P}_{2} \mathrm{O}_{6}$ \\
\hline $\begin{array}{l}M-7 \ldots \ldots \ldots \\
M-15-16-17 a \ldots \\
M-43 . \ldots \ldots \ldots \ldots \\
M-52 \ldots \ldots \ldots \ldots \\
M-62 \ldots \ldots \ldots \ldots\end{array}$ & \multirow{3}{*}{ 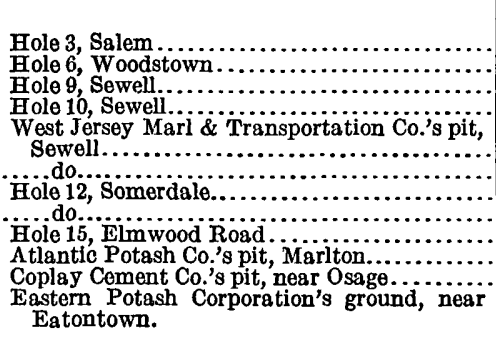 } & \multirow{3}{*}{ 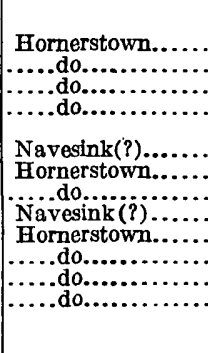 } & \multirow{2}{*}{$\begin{array}{r}\text { Per cent. } \\
2.97 \\
.60 \\
.07 \\
.52 \\
.20 \\
1.49 \\
.17 \\
.08 \\
2.86 \\
1.84 \\
\text { None. } \\
\text { None. }\end{array}$} & \multirow{2}{*}{$\begin{array}{r}\text { Per cent. } \\
0.68 \\
.25 \\
\text { Trace. } \\
.31 \\
\text { Trace. } \\
.38 \\
.17 \\
.15 \\
1.79 \\
1.24 \\
.33 \\
.26 \\
\end{array}$} \\
\hline $\begin{array}{l}\mathrm{M}-63 \ldots \ldots \ldots \\
\mathrm{M}-75 \ldots \ldots \ldots \\
\mathrm{M}-78-796 \ldots \ldots \\
\mathrm{M}-99 \ldots \ldots \ldots \\
\mathrm{K} . \ldots \ldots \ldots \\
\mathrm{M}-126 \ldots \ldots \ldots \\
\mathrm{M}-127 \ldots \ldots \ldots\end{array}$ & & & & \\
\hline & & & 1.08 & .56 \\
\hline
\end{tabular}

a Compasite sample of one-third each of M-15, M-16, and M-17.

$b$ Composite sample of one-half each of M-78 and M-79. 
The phosphoric acid and lime content of the three principal marl beds in New Jersey is relatively low, but the Manasquan marl has a greater proportion of these substances than the other two beds. On the other hand, as previously noted, it is poorer in potash.

\section{ACCOMPANYING WATER.}

At many localities the marl beds contain water, especially in the southwestern part of the State, where the elevations are generally lower than in the northeastern part. Much of the water has an unpleasant taste of iron or is slightly sulphureted and is unsuited for drinking. One sample of about 2 quarts was collected for analysis at Woodstown. A number of samples of marl collected wet were thought to contain sufficient water, singly or as composites, for analysis. The waters, however, proved insufficient for this purpose. Probably a gallon of each sample would be required for complete analyses.

By combining the supernatant water from 11 samples (M-98 to M-108 inclusive) from hole 15 and similarly the water from 10 samples (M-109 to M-118 inclusive) from hole 16, both at Elmwood Road, sufficient liquid was obtained for partial analyses, which represent the waters from these holes. The analyses of these composite samples and of sample 24 from hole 7 , at Woodstown, are given in the following table. Only four of the more important substances were determined in each sample.

Partial analyses of water samples from New Jersey greensand.

[R. K. Bailey, analyst.]

\begin{tabular}{|c|c|c|c|}
\hline - & $\begin{array}{l}\text { Hole 15, } \\
\text { Elm- } \\
\text { wood } \\
\text { Road. }\end{array}$ & $\begin{array}{l}\text { Hole 16, } \\
\text { Elm- } \\
\text { wood } \\
\text { Road. }\end{array}$ & $\begin{array}{l}\text { Hole 7, } \\
\text { Woods- } \\
\text { town. }\end{array}$ \\
\hline Soluble salts.... & $\begin{array}{r}\text { Per cent. } \\
0.029\end{array}$ & $\begin{array}{r}\text { Per cent. } \\
0.0265\end{array}$ & $\begin{array}{r}\text { Per cent. } \\
0.0088\end{array}$ \\
\hline \multirow{2}{*}{$\begin{array}{l}\mathrm{SiO} \\
\mathrm{Cg} \\
\mathrm{Na} \\
\mathrm{K} \\
\mathrm{U} \\
\mathrm{U}\end{array}$} & $\begin{array}{r}19.10 \\
21.40 \\
8.23 \\
3.33 \\
47.94\end{array}$ & $\begin{array}{r}11.37 \\
21.07 \\
9.35 \\
3.80 \\
54.41\end{array}$ & $\begin{array}{r}8.32 \\
38.10 \\
13.20 \\
5.97 \\
34.41\end{array}$ \\
\hline & 100.00 & 100.00 & 100.00 \\
\hline
\end{tabular}

The percentages of soluble salts in these waters are so small that the apparently substantial amounts of potassium correspond respectively to $9.6,10$, and 5.2 parts per million. This is probably far below the saturation point for potassium, for in the table showing percentages of water-soluble potash (p. 129) the content of potash, so far as given, ranges from 0.02 to 0.06 per cent $\mathrm{K}_{2} \mathrm{O}$, equivalent to about 0.018 to 0.05 per cent potassium. These percentages correspond respectively to 180 and 500 parts per million. 
In laboratory determinations of water-soluble potash it is customary to boil the material in water for perhaps half an hour to produce the solution, whereas in the ground solution takes place at a much lower temperature and hence much more slowly. On the other hand, the water which percolates slowly through the beds has the advantage of long-continued contact with the greensand.

The disparity between the amount of potassium present and the amount required for saturation suggests that potassium is being withdrawn from solution. The silica, lime, and soda and the relatively large percentage of undetermined substances suggest that the other constituents of glauconite may be present in sufficient quantity to unite with potassium to form glauconite and that this action may be the cause of the withdrawal of potassium from solution.

That other substances are formed as well is shown by the occurrence here and there of vivianite, marcasite, iron carbonate, and phosphatic nodules.

Solution and deposition are processes that have doubtless been going on within the marl beds at different places at the same time or at the same place at different times. The present composition of the waters represents the balance between the two sets of conditions at the time of sampling.

\section{ENRICHMENT.}

POTASH.

- Cook ${ }^{73}$ states that "the best marls will always be found below the natural drainage of the country, or at least where they have never drained out to dryness." This statement does not seem to be borne out by the present investigation. In the table summarizing the field data obtained in the borings (p. 104) the thickness and potash content of each of the principal marl beds are given for each locality. The green and chocolate marl beds were in large part or entirely below the water table in four of the five localities. At the Somerdale borings, however, all the marl beds were above the water table and were practically dry, yet the potash content of each of the two beds represented (the uppermost bed had been eroded) was comparable to that of the corresponding beds at the other localities. For example, the green marl at Somerdale contained slightly less potash than that at Sewell and Woodstown but more than that at Salem and Elmwood Road.

The borings show that the green marl averages 1.1 to 1.28 per cent more in potash content than the other two beds. This difference appears to be due, in part at least, to its relatively less admixture of quartz. This is shown on the table on page 119, where the results 
of the magnetic separation of residues are given. Thus it is probably in the main a feature of original bedding rather than of subsequent enrichment. The green marl is usually distinct lithologically from the overlying or underlying bed. This again is probably a feature of original bedding.

At some localities, however, notably at Sewell (see pp. 47-52), there is clear evidence of leaching and oxidation of the upper part of the marl and consequent impoverishment in potash. Although the marl beneath has a distinctly higher potash content it is not clear that this is due to enrichment rather than to original deposition. At the Somerdale borings (pp. 7,61-64) the Hornerstown marl has been in part eroded and is overlain by reworked marl of Quaternary age. This reworked material is distinctly oxidized and contains less potash than the uneroded marl beneath, but this uneroded marl, which is part of the green bed, is not unduly high in potash.

Without doubt potash is locally being leached from the marl and is passing into solution. With little doubt, too, as suggested above, it is being abstracted from solution, but there seems to be no readily distinguishable zone of enrichment unless the green marl bed may be so considered. With regard to what becomes of this potash the following tentative suggestions are worthy of attention:

1. Clay, which is believed to have an important share in the formation of glauconite (see section on nature and origin of glauconite, pp. 138-142), was probably abundant in the original muds from which the glauconite was formed-witness the alumina present in all the analyses of glauconite and greensand cited above. It was probably more abundant in some beds than others. Thus the green marl bed with less quartz probably had a larger proportion of clay.

2. When the marl beds became part of the land area and were subjected to the action of meteoric waters the processes of oxidation and leaching of certain layers began. Some potash with other constituents went into solution and circulated through the marl beds. The potash-bearing solutions reacted with the clay to form new glauconite, and the action was more pronounced in the more clayey layers-for example, the green marl bed. Some of the new glauconite formed additions to existing grains, but some of it formed amorphous or colloidal glauconite such as that which now constitutes so marked a feature of certain beds.

3. The difference in potash content between the recent glauconites and older glauconites shown in the tables on pages 127-128 has significance in this connection, as does the remark of Collet cited with those tables. It seems quite possible that the development of glauconite begun in muds offshore may have continued by the process outlined above and may thus have enriched the undisturbed marl beds, through which the waters circulated. 
U. S. GEOLGGTCAL SURVEY

BULLETLN 727 PLATE $X$

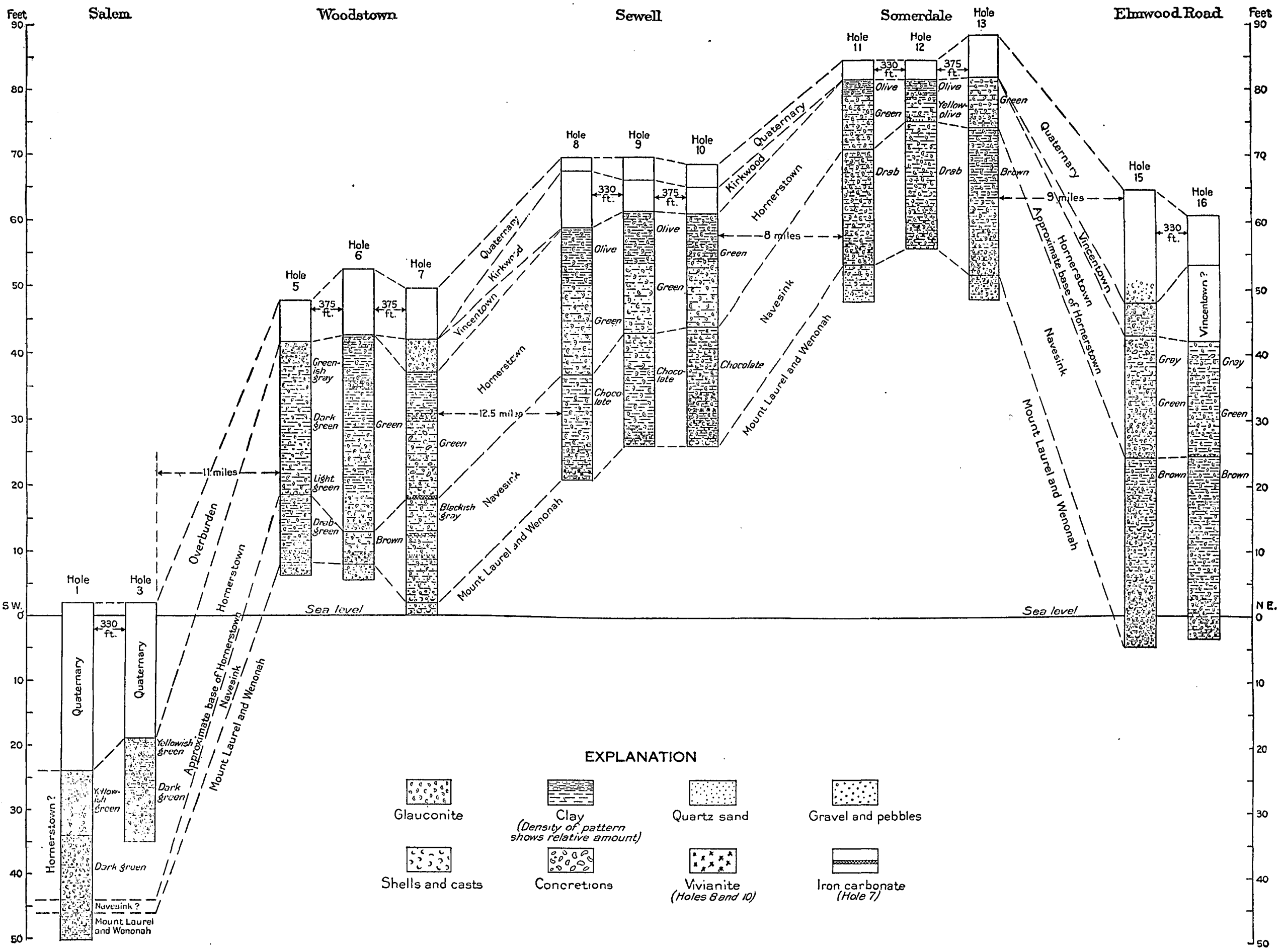

STRATIGRAPHIC COMPARISONS OF BORINGS AT SALEM, WOODSTOWN, SEWELL, SOMERDALE, AND ELMWOOD ROAD, N. J. 
4. The changes of level to which the marl beds, together with the entire Coastal Plain, have been subjected have permitted all the marl beds, even those that now lie above the water table, to be subjected to the action of ground water for protracted periods.

\section{OTHER SUBSTANCES.}

Iron carbonate, somewhat phosphatic, forms the hard, stony layer at the base of the Hornerstown marl at hole 7, at Woodstown, and probably also forms part of certain nodules and casts that are strongly phosphatic. The stony layer is localized at a horizon that is thought to mark the boundary between two formations. The nodules and casts are distributed rather irregularly. All bear witness to the activities of solution and deposition in the circulating waters.

Ironstone, or sedimentary material cemented by oxide of iron, occurs at many places and at a number of horizons-for example, at the pit of the R. S. Ryan Co. near Medford. Here it occurs along the contact between the Hornerstown marl and the overlying Quaternary gravels. (See p. 80.) This material also bears witness to the activities of ground water. It is locally of sufficient abundance to be quarried as stone.

\section{STRATIGRAPHIC NOTES.}

Southwest of Sykesville, in Burlington County, two broad lithologic units are present-an upper formation, predominately green to greenish black, and a lower formation, brown to brownish black, the so-called chocolate marl. The contact between the two formations is well defined and usually marked by the presence of sand or gravel grains near the base of the green formation. Locally a water-bearing gravel bed, shells, or an indurated layer occur at the contact. This contact would be a convenient lithologic boundary for the Navesink and Hornerstown marls and is tentatively so considered in this paper. A single cast thought by T. W. Stanton to be that of Cucullaea vulgaris, a wide-ranging form but common in the Hornerstown, was taken from a gravel bed at this contact at Elmwood Road. (See Pl. X, hole 16.) It suggests that the Hornerstown includes all of the green formation at that locality.

This gravel bed and the sand and gravel grains elsewhere at the contact may represent the southwestern continuation of the Redbank sand. The stratigraphic features of the combined Hornerstown and Navesink marls at the different borings are shown in Plate $X$.

The Navesink grades downward into the Mount Laurel but appears to rest on a fairly uniform surface at each of the localities drilled, except at Woodstown and Sewell, where variations of about 4 and 5 feet, respectively, in distances of 330 and 375 feet down the 
dip were observed. These figures would indicate a dip of 64 and 80 feet to the mile, respectively, at these localities, whereas the average calculated by Knapp, as previously stated, is only 33 feet. This apparently greater local dip may prove to be more widespread, or it may indicate local current scour in the Mount Laurel sands prior to the deposition of the Navesink.

The thickness of the Navesink is about 28 feet at Elmwood Road, 23 feet at Somerdale, $17 \frac{1}{2}$ feet at Sewell, 14 feet at Woodstown, and 2 feet (?) at Salem. At Salem there is no very clear basis for distinction between the Navesink and Hornerstown. The shell bed with rice gravel at the base appears to be Navesink, but the marl above in quality and appearance suggests Hornerstown rather than Navesink. At Sewell a depression in the top of the formation corresponding to that in which the base lies was observed. At Woodstown a depression of 5 feet was found in a distance of 375 feet along the strike, together with a total observed variation of 9 feet in thickness at the three holes. These features, together with the scant representation of the formation at Salem, may indicate local erosion of the upper beds by current scour or otherwise. On the other hand, at several of the holes the upper beds of the formation show a transition interval of 6 inches to several feet in which streaks of green material are intermingled with the brown.

In general the Navesink marl is more clayey at the top, less clayey and correspondingly more glauconitic in the middle, and more sandy near the base. The less clayey portions slump easily and tend to run like quicksand. At Woodstown a water-bearing gravelly layer was encountered at hole 7, which was not represented at holes 5 and 6 . At Sewell a hard sandy layer with vivianite was found in hole 10 which did not occur at corresponding depth in holes 8 and 9, though in these an increasing proportion of quartz sand was noticed. At Somerdale the intermingling of brown and green material was present throughout the formation.

The basal features of the Hornerstown marl have been mentioned in connection with the description of the Navesink. The top of the formation, as represented by the Terebratula-bearing bed, was found in only one of the holes. Elsewhere portions of the Hornerstown had been eroded. Nevertheless the measurements show that this formation maintains or even increases its thickness toward the southwest. For example, at Elmwood Road, where the Terebratulabearing bed is present, the thickness is 17 feet 7 inches. At Somerdale the formation is considerably eroded, but from 6 to 11 feet remains. At Sewell the maximum thickness measured is nearly 22 feet, at Woodstown 27 feet, and at Salem 21 feet.

In general, the Hornerstown marl as observed in these borings is more clayey and lighter in color in the upper part and more glauco- 
nitic and darker below. Near the base sand and gravel grains and, locally even tiny pebbles appear. Local variations may be noted. -For example, at Woodstown a stony layer about 6 inches thick, somewhat phosphatic and containing much iron carbonate, occurs at the base in hole 7 but is not found in holes 5 and 6 . Similarly, at Woodstown shells were present at the base in holes 5 and 7 but absent in hole 6. At Sewell a light-green clayey bed 4 feet thick at hole 8 is only 6 inches thick 375 feet away at hole 10 . Other variations in color and texture were noted at different localities and at different holes in the same locality.

The three holes bored in the Manasquan marl near Pemberton were not deep enough to pass through the formation, but they showed some variations in character and thickness of the marl. The uppermost member, a relatively light colored sandy clay with comparatively little glauconite, was 3 feet thick at the first hole and more than 14 feet thick at the second, only 330 feet distant. The lower, darkgreen glauconitic nember was more than 9 feet thick at the first hole and less than 3 feet thick at the second. At the third hole, which was nearly a mile and a half away, only the dark-greenish member was exposed, more than 15 feet thick.

These irregularities in the greensand beds suggest that their accumulation did not take place entirely beyond the range of wave and current action.

\section{CONDITIONS OF SEDIMENTATION.}

The bedding of the greensand, as previously noted, is generally regular, so far as observed. Some beds show a fine lamination. There is more or less alternation of clayey layers with more glauconitic beds. Quartz grains, generally angular or subangular rather than rounded, are distributed somewhat unevenly throughout the glauconite beds. The sizes of the quartz grains agree in a general way with those of the glauconite, but the preponderance of the 40 and 60-mesh grains is less marked. The specific gravity of glauconite is slightly less than that of quartz, so that under the same conditions of sedimentation the glauconite grains might be expected to have a somewhat greater average size.

The distribution of the quartz grains indicates a generally steady but slow influx of land-derived material from which the more soluble rock fragments had largely been removed. The presence of the clay and glauconitic mud included with the greensand indicates generally quiet waters. The maintenance of these conditions long enough to build up such an extensive and relatively thick deposit suggests a slow subsidence of the bottom on which the deposits were accumulating or a gradual transgression of the sea upon the land. The $88625^{\circ}-22-10$ 
Vincentown and Redbank sands indicate that the glauconite-forming agencies were at times interrupted or impeded by reversal of conditions, the sea retreating or becoming shallower during the epoch of their formation. Minor reversals or oscillations of conditions during the deposition of the greensand are indicated by the presence of the sandy or gravelly layers described above.

The local variations in the thickness of the supposed Navesink marl previously mentioned suggest that from time to time the generally quiet bottom conditions were disturbed by oceanic currents or by waves.

A rather abundant and varied life inhabited the waters in which the greensand beds were being deposited, as shown by the shells and other types of fossils that have been recovered from the marl beds. Lists of these fossils are given by Clark ${ }^{74}$ and Weller. ${ }^{75}$ These animals furnished by their decay the organic matter generally supposed to be necessary for the formation of glauconite.

According to Murray and Renard, ${ }^{78}$ glauconite forms most abundantly at about the lower limits of wave, tide and current action, in the neighborhood of what may be called the mud line-that is, at about 200 to 300 fathoms. The temperature of the ocean at these depths off Sandy Hook is between $40^{\circ}$ and $45^{\circ} \mathrm{F}$. If, as seems probable, the conditions of the formation of glauconite in Cretaceous time were similar to those of to-day the depth of the sea water over New Jersey in the Navesink and Hornerstown epochs was 1,200 to 1,800 feet.

\section{NATURE AND ORIGIN OF GLAUCONITE.}

Glauconite is a constituent of various marine sediments now forming along the shores of the continents, usually at depths greater than 600 feet, but ranging from about 300 feet to somewhat more than 2 miles. It is not formed in the deeper parts of the ocean, except from accidental causes, nor along coasts where great rivers, such as the Amazon, bring large quantities of sediment into the sea. It is associated chiefly with greensands and green muds, though present in blue muds, volcanic muds, and some of the oozes; and it is widely distributed in the Atlantic, Pacific, and Indian oceans and the Mediterranean Sea. Glauconite is also widely distributed in time, having been formed in all the great geologic periods.

The chemical and mineral composition of glauconite is variable, though part of the apparent variation may be due to the difficulty of procuring pure material for examination and analysis. There is

\footnotetext{
${ }^{74}$ Clark, W. B., A preliminary report on the Cretaceous and Tertiary formations of New Jersey: New Jersey Geol. Survey Ann. Rept. for 1892, pp. 169-239, 1893.

${ }^{75}$ Weller, Stuart, Upper Cretaceousformationsand faunas of New Jersey: New Jersey Geol. Survey: Ann. Rept. for 1904, pp. 145-160, 1905.

70 Murray, John, and Renard, A. F., Challenger Rept., Deep-sea deposits, p. 383, diagram 2, 1891.
} 
some doubt whether the mineral is really a definite substance. It is also thought that glauconite may include members of a series of minerals, in the same manner as the chlorites and micas. ${ }^{77}$ Glauconite is essentially a hydrous silicate of iron and potassium and, according to Clarke ${ }^{78}$ probably has when pure the composition represented by the formula $\mathrm{Fe}^{\prime \prime}{ }^{\prime} \mathrm{KSi}_{2} \mathrm{O}_{8}$.aq., in which some iron is replaced by aluminum, and other bases partly replace $K$. Thus it should contain about 13 per cent of potash..$^{7}$ The analyses show, however, that the potash is practically always partly replaced so that it rarely exceeds 7.50 to 8 per cent. Dana ${ }^{80}$ gives the hardness of glauconite as 2 and its specific gravity as $2.29-2.35$. It is usually amorphous and has a granular texture.

Glauconite occurs chiefly in tiny irregular botryoidal or rounded grains, some of which appear to be casts of foraminiferal or other calcareous shells. The greater number, however, show no direct relation to foraminiferal form. Many of the grains are worn and have evidently been transported and redeposited. Cayeux ${ }^{81}$ describes and figures a type of grain relatively rare, in which a thin superficial coating with radial structure, visible only in thin sections with strong magnification, was observed. Collet ${ }^{82}$ suggests that these coatings may represent glauconitic pseudomorphs after the calcite of foraminiferal shells. Another type of grain described by Lacroix ${ }^{83}$ and relatively rare is thought to be crystalline and monoclinic. It is strongly pleochroic, has a well-recognized cleavage, and under crossed nicols in polarized light extinguishes parallel to the cleavage. Still another type, called by Cayeux pigmentary glauconite, stains the cement of consolidated sediments and forms coatings on grains of other minerals or fillings in the cracks of minerals such as feldspar.

A number of microscope slides were made showing thin sections of glauconite and of some of the associated mineral grains of different sizes from the New Jersey borings of the present investigation. The noteworthy features of the glauconite, as shown in these sections, are (1) the absence of concentric or radio-fibrous structure; (2) the absence of any skeleton or core of other mineral matter; and (3) a uniform or nearly uniform aggregate structure of tiny crystalline

\footnotetext{
77 Goldman, M. I., General character, mode of occurrence, and origin of glauconite: Washington Acad. Scl. Jour., vol. 9, pp. 501-502, 1919 (abstract); The petrography and genesis of the sediments of the Upper Cretaceous of Maryland: Maryland Geol. Survey, Upper Cretaceous, p. 179, 1916.

${ }^{78}$ Clarke, F. W., The data of geochemistry, 4th ed.: U. S. Geol. Survey Bull. 695, p. 513, 1920.

${ }^{79}$ Ashley, G.H., Notes on the greensand deposits of the eastern United States: U.S. Geol. Survey Bull. 660, p. 34, 1918.

Bo Dana,J. D., System of mineralogy: Descriptive mineralogy by E.S. Dana,6th ed., p. 683, New York, 1914.

81 Cayeux, Lucien, Contribution à l'étude micrographique des terrains sédimentaires: Soc. géol. Nord Mém., vol. 4, No. 2, p. 164, 1897.

${ }^{82}$ Collet, L. W., Les dépots marins: Encyclopédie scientifique, p. 141, Paris, 1908.

as Cited by Cayeux, Lucien, op. cit., p. 165.
} 
flakes, which, in polarized light, show an aggregate polarization without general extinction. (See Pl. IV, p. 6.)

The absence of skeleton or core is in distinct contradiction to the idea of Hart" that glauconite "consists of a core, which is apparently pure silica, and a covering layer of glauconite containing apparently no, or very little, silica."

Some grains, presumably those described on page 122 as having a platy structure or cleavage, show these features with parallel extinction in thin sections and are pleochroic. These may prove to be crystalline glauconite like that described by Lacroix. A grain of feldspar, in which flakes of glauconite had evidently been formed in cracks, was observed in one of the sections. The glauconite was apparently fresh and relatively pure and free from alteration. A few grains, however, showed encroachment of iron sulphide. The seedlike or capsule-shaped grains are isotropic. They are phosphatic and contain numerous tiny black particles that may be magnetite. Some of them contain grains of green glauconite.

The origin of glauconite is still imperfectly understood. According to Murray and Renard ${ }^{85}$ organic matter inclosed in the shells and present in the mud itself transforms the iron in the mud into sulphide, which may be oxidized into hydrate, sulphur being at the same time liberated. The sulphur becomes oxidized into sulphuric acid, which decomposes the fine clay, setting free colloid silica, alumina being removed in solution. The colloid silica and hydroxide of iron are in a condition most favorable for their combination, and in the presence of potash salts in sea water these substances form glauconite. Collet $^{86}$ suggests in modification of these views three stages for which hecites evidence-(1) the formation of gray casts composed exclusively of clay; (2) the formation of brown casts of different shades representing different stages in the replacement of clay by peroxide of iron, no potash being present; (3) "glauconitization," the introduction of potash and probably also of the water of constitution.

Murray and Renard ${ }^{87}$ regard it as improbable that any minute grains of glauconite are formed in a free state in the mud. They think that this mineral is formed in the cavities of calcareous organisms, though they admit that some grains appear to be highly altered fragments of ancient rocks or coatings of glauconite on these rock fragments. They state that shells are broken by the swelling out or growth of the glauconite and that subsequently the isolated cast becomes the center upon which new additions of the same substance take place, the grain enlarging and becoming more rounded in a

84 Hart, Edward, Glauconite or greensand: Am. Chem. Soc. Jour., vol. 39, p. 1919, September, 1917.

${ }_{83}$ Murray, John, and Renard, A. F., Challenger Rept., Deep-sea deposits, p. 389, 1891.

${ }^{86}$ Collet, L. W., op. cit., pp. 176-178.

87 Murray, John and Renard, A. F., op. cit., pp. 387-388. 
more or less irregular manner, as in the formation of concretionary substances. Although the irregularities of shape and the general scarcity of grains with definite foraminiferal form may perhaps be explained in this way, the coatings and accretionary layers noted suggest that other modes of origin besides that within calcareous shells may be important.

Cayeux ${ }^{88}$ cites a variety of evidence to show that organic matter is not essential to the origin of glauconite grains. He ascribes an important share in their genesis to the so-called pigmentary glauconite, and shows that grains of glauconite have originated or have continued to increase in size after all the elements of the accompanying sediments were in place as in a consolidated deposit. He concludes that organic matter may be more of ten the primordial condition of the production of glauconite, but that it is very certain in many places that organic matter has had no part in the genesis of this mineral.

Collet ${ }^{89}$ also recognizes the important part that pigmentary glauconite may play in the origin of glauconite grains and adds that the absence of cement in microscopic sections of glauconite may be explained by the fact that both the glauconite grains and the glauconitic cement are cryptocrystalline and composed of particles differently oriented so that suture lines would be masked.

On page 126 the fine material washed from composite samples of New Jersey greensand beds is shown to contain approximately 3 to 7 per cent of potash. It consists largely of greenish to yellowish colloidal matter that may be classed as pigmentary glauconite. It may be part of the original deposit, in which for some reason grains of glauconite did not develop, or it may have originated by mechanical wear or disintegration of previously existing grains. It may, however, have been formed by the chemical action of the circulating waters upon clay in the marl. Possibly grains of glauconite may be forming in it to-day, but of this no direct evidence was observed.

With reference to celadonite, a mineral closely related in composition to glauconite, Clarke ${ }^{80}$ remarks:

If, now, we assume that celadonite and glauconite are at bottom the same ferripotassic silicate, differing only in their impurities, we may begin to see that the several modes of its formation are not absolutely different after all. Probably, in all their occurrences, the final reaction is the same, namely, the absorption of potassium and soluble silica by colloidal ferric hydroxide. In the ocean these materials are prepared by the action of decaying animal matter upon ferruginous clays and fragments of potassium-bearing silicates. In the sedimentary rocks, where glauconite appears as a late

88 Cayeux, Lucien, op. cit., pp. 176-184.

collet, L. W., op. cit., pp. 154, 155.

0 Clarke, F. W., The data of geochemistry: 4th ed.: U. S. Geol. Survey Bull. 685, pp. 514-515, 1920. 
product, the action of percolating waters upon the hydroxide would account for its formation. In igneous rocks the hydroxide is derived from augite, or perhaps from olivine, and percolating waters again come into play. Thus the various productions of glauconite and celadonite become the results of a single process, which is exactly equivalent to that in which potassium compounds are taken up by clays. The observation of L. Cayeux that glauconite is frequently present in arable soils, in all conditions from perfect freshness to complete alteration into limonite, suggests that perhaps the formation of the species is one of the modes by which potassium is withdrawn from its solution in the ground waters.

This statement tends to confirm the suggestions presented above in the discussion of enrichment.

Fuller discussions of the nature and origin of glauconite are given in some of the papers cited, notably those of Cayeux and Collet, which contain bibliographies of the subject. 


\section{INDEX.}

A.

\begin{tabular}{lr} 
A. & \multicolumn{1}{c}{$\begin{array}{c}\text { Page. } \\
\text { Abstract of the report.................. VII-VIII }\end{array}$} \\
Acids, solubility of greensand in........... & 129 \\
Acknowledgments for aid.................. & $2-3$ \\
Age of glauconite beds................... & 7
\end{tabular}

Agriculture, value of greensand in, earlier views on.................. 115-116

Department of, experimental use of marl by.

Alkali lakes, cost of producing potash from. 111-112 Allen, Joseph, record of well of............. 34 Alloway, record of two wells near.......... 26-27 Alunite, cost of producing potash from...... 112 American Potash Corporation. See Kaolin Products Corporation.

Analyses of greensand, chemical, character and number of............... 122-123

chemical, results of................ 123-133 mechanical, processes and results of.... 116-122 Anspach, F. J., record of well of ........... 52-53 Asbury Park, record of well at........... 100-101 "Ash marl." See Manasquan marl.

Atlantic City, record of deep well at........ 103 Atlantic Potash Co., experimental work by. 108-109 marl pit of.......................... 76-77

Auburn, record of well near............... 38

Availability of potash in greensand.... 113-115, 129

B.

Bank marl, use of term

Barnsboro, records of wells near........... 42-45

Barr, J. W., record of well of.............. 75

Bateman, S. R., record of well of.......... 59-60

Beach House, Sea Girt, record of well at... 101-102

Bedding of greensand..

6
55

Behl, Felix, record of well of.............. 55

Birmingham, deposits of marl near ... 85-88, 90, 105 record of well near.................... 83

Blackley, Edward, record of well of.......... 83

Blackwood, exposures near............... 58-59 record of well at ..................... 59 section in marl pits near.............. 58

Borings, stratigraphic comparisons of, plate showing.

Borton, J. Gilbert, record of well of...........

Bradevelt, location of..

Brown, Frank, record of well of.

Bury I., record of well of............

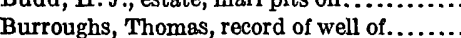

c.

Camden, section southeast of, plate showing . Celedonite, similarity in formation of, to that of glauconite.
Chalfont, Dr. W. P., record of well of.... Page.

Challenger expedition, analyses of glauconite collected by .................. 127

Character of the deposits................. $\quad 5-6$

Cheesman, Benjamin, record of well of....... 38

Chocolate marl, use of term................ 6

Clarke, F. W., cited................... 141-142

Clay, nature of .......................... 5

"Clay-marl series"...................... 8-9

Coastal Plain, glauconite deposits in....... 6-7

Cole, William, record of well of............. 35

"Columbus sand"'....................... 9

Composition, chemical, of glauconite...... 127-128

chemical, of greensand............. 123-125

Composting of greensand, results obtained from....................... 114-115

Cook, G. H., cited.............. 58, 115-116, 131 Coplay Cement Manufacturing Co., production of potash by ............ 109-110

Cosgrove, Peter, record of well at creamery of. $\quad 89$

Cost of producing potash in Americ\&....... 111-113

Craven, Stewart, record of well of........... 24

Cream Ridge, marl pit near............... 94

Cretaceous and later formations in Coastal Plain region, table and descrip. tions of...................... 7-13

"Crosswicks clay"....................... \& 8-9

Crosswicks Creek, exposures of marl on...... 93-94

Crowshsw, Ellis, record of well of.......... $\quad 91$

D.

Davis, Howard, section in marl pit of...... 56-57

Davis, J. Q., record of well of.............. 24

Davis, marl pit at..................... 94

Deposits, conditions during formation of... 137-138

location of......................... 4

Development, commercial, efforts toward.. 107-110

Dilks Bros., record of wells of.............. 43

Dilks, Charles, record of well of............ 44

Dip of greensand beds.................... $\quad 6$

Dobbins, J. W., analyses of marl from pit of. $\quad 86$

Drilling, method of....................... 15

selection of sites for ................. 14-15

Dunphey, H. B., record of well of ......... 73

E.

Eastern Potash Corporation, analyses of marl from property of............... $96-97$ process developed by .................. 108

Eatontown, marl at and near............. 96-97 transportation from.................. 98

12 Eayrestown School, record of well at........ 80

Edwards Run, exposures of marl on....... 42-43

Elberon, marl at and near............... 99-100 
Page.

Eldridge, Joseph, record of well of......... 65-66

Elmwood Road. See Marlton district.

Englishtown sand, description of.

Enrichment of potash.................. 133-135

Evans, Joseph, record of well of............ 75

Exposures, nature of .................... 14

\section{F.}

Fairview, record of well at

Farmingdale, marl at and near............ 97-99 marl pit at, plate showing.............. 80

Fertilizer, quantity of greensand marl used as........................... 1 suitability of greensand as...... 113-115, 128-129

Field work, methods employed in......... 14-20

Flue dust, cost of producing potash from... 112 use of greensand with, in producing potash...................... 109-110

Fogg, Louis, drilling on farm of.......... 22 Forage crops, value of greensand for....... 113

Formations, commercially important....... 12-13

Fossils, occurrence of ................ $11,22,24,37,42,43,44,47,49,55,60,70$, $71,74,79,83,91,92,94,100,101,102,138$

Freehold, marl at...................... 95-96 Fusco, Alphonso, drilling on farm of....... 70-73

\section{G.}

Gale, H. S., and Hicks, W. B., cited...... 111-112 Gardiner, S. C., record of well of

Geologic map of greensand beds, Imlaystown to Sandy Hook..............In pocket. Laurel Springs to Cream Ridge...... In pocket. Salem to Blackwood............. In pocket.

Glauconite, chemical composition of ....... 127-128 distribution of........................ 138 mode of occurrence of .................. 5 nature and origin of $. \ldots \ldots \ldots \ldots \ldots \ldots, 138-142$ photomicrographs of size and shape of grains of......... $5,110-122$

Gray marl, use of term.................... 6

Green marl, use of term................... 6

Greenloch, record of well near............ 59-60

\section{H.}

Hagerville, record of well near.

Haines, J. Clifford, marl pit of ....... $83-84$

Harper, - , record of well of................ $85-86$

Harris, Howard, overburden penetrated by well of.

"Hazlet sands" . . .........................

Heinz, H. J., Co., record of well of..........

Hicks, W. B., cited.................... 110-111

Higgins, Charles, record of well of........... 94

Hires, Lucius, drilling in meadow of........ 23

Hoffman, William, marl pit of............. 85 marl pit of, plates showing............. 14, 80

Hope Creek, well near, thickness of marl in.. 26

Horner, Ivins, marl pits of.................. 89-90

Hornerstown, marl at and near............ 93-94

Hornerstown marl, description of........... 11

Huggins marl pit, section at............. 93

Hummel, Dr., overburden penetrated by well of..

Hurfiville, record of well near.
I.

Page.

Imlaystown to Sandy Hook, geologic map of area.................... In pocket.

Irick, William J., record of well of........ 81-82 Iron carbonate, occurrence of............. 135 Ironstone, occurrence of ................. 135

\section{J.}

Jacobstown, marl near.................... . 92

Jessup, James, records of well of .......... 44, 45 Jobstown, marl at and near............... 90-91 Johnson, J. H., marl pits of................ 98

\section{K.}

Kaolin Products Corporation, experimental work on potash by............ 107-108

Kern pits near Sewell, features of........... $\quad 56$

Kirkwood, record of well near.............. $\quad 65$

section in marl pit near. ................ 66

Kümmel, Henry B., cited................. . 93

L.

Lakewood, record of two wells at.........., 102

Laurel Springs, record of well near.......... $65-66$

Laurel Springs to Cream Ridge, geologic map of area................ In pocket.

Lime, content of, in marl............. 130-132 Lime sand, analyses and localities of....... 27 $28,39-40,57,60,67,77,81$

estimated quantity of................ 107

Lippincott, Isaac K., drilling in field of. ..... 31-34 Lloyd, Parvin, record of well of............ 26-27 Locke, David T., record of well of .......... 53

"Lower marl" ............................ 10

\section{M.}

McAllister, Thomas, record of well of ......... McCall, A. G., and Smith, A. M., experiments of, on composts containing greensand....................... 114-115

McMichael, Thomas, drilling on farm of..... 61-65 Magothy formation, description of.......... 8 Mahoney, D., marl pit of................ 97-98 Manasquan marl, description of........... 12 Manasquan River, section on.............. 99 Mannington Creek, exposures of marl on..... 27

Map, geologic, features of .................. 20

Marl, enrichment of potash content of..... 133-135

kinds of............................. 5

red, constituents of .................... 6

test of, by U. S. Department of Agriculture..................... 95, 115 thickness and quality of, averages of... 103-106 Marlboro, marl at and near................ 94-95 test of marl from................... 95, 114 Marlton, pit of Atlantic Potash Corporation near, plate showing............. 76

Marlton district, exposures of marl in........ $76-77$

limesand in .......................... 77 records of holes in . .................... $70-73$ records of wells in................. 73-76 sampling trough in use in, plate showing. $\quad 16$ selection of area in.................. 68-69 thickmess and potash content of marl beds in ...................... 104 tonnage and value of marl in.......... 77 utilization of deposits in.............. $\quad 78$ 


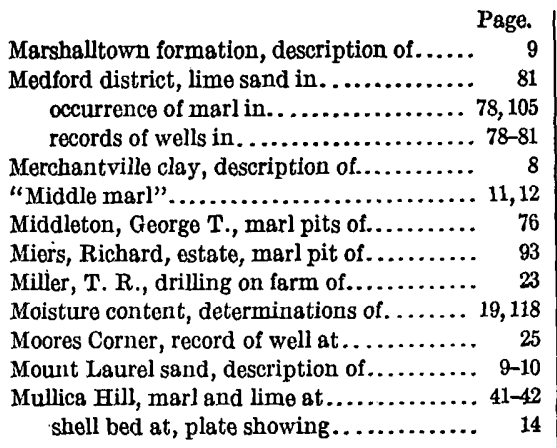

N.

Names, local, of marls.................... 6

Nature of greensand and marl............ $5-6$

Navesink marl, description of............. 10

New Egypt, marl at and near............. 92-93

New Jersey Department of Conservation and Development, cooperation by...

Noncross \& Edmunds Co., marl under sand pits of...................... 86-88

North, J. L , record of well of.............. 53

\section{o.}

Occurrence of greensand marl, mode of...... Ocean Grove, record of well at.

Organic matter in greensand, determinations of .......................... 130

Osage station, exposure in marl pit near.... 66-67

$$
\text { P. • }
$$

Pemberton, deposits of marl near. $88-90,105$

Pettit, James, record of well of.

Phosphoric acid, content of, in marl........ 41, $88,90,95,96,98,130-132$

Pine, F; record of well of. $88,00,05,90,88,130-132$

Pitman, records of well at............... $55-56$

Pits, condition of..

14

Plants, assimilation of potash from greensand by.

Poplar, marl near

Potash, commercial production of......... 107-110 content of, in fines from washing...... 125-126 in marl.

$57,66,67,76,77,80,84,85$,

$88,90,95,96,97,98,99,104$

See also Analyses, chemical,; and records of holes.

- method of determining............ 18

German, prices of............ 110-111,112-113

in greensand, conversion of, into soluble form....................... 114-115 quantity of, estimated................. 106-107 water-soluble, in greensand............ 129 wholesale price of, $1915-1918 \ldots \ldots \ldots \ldots . .111$

Potatoes, value of greensand for......... 115-116 Powell, Jerry, overburden in well of......... Preparation of samples for mechanical analysis.
Q.

Page.

Quantity of greensand, estimated.......... 106-107 Quartz, in washed greensand, content of... 118-119 in washed greensand, shapes of grains of.. 122 size of grains of................. 119-122 Quinton, records of wells near............26,27

\section{R.}

Raritan formation, description of.......... $\quad 8$

"Red sand".............................. 11

Redbank sand, description of............. 10-11

Reduction \& Concentration Corporation experimental work by.......... 109

Reeve, Samuel C., record of well of......... 26-27 Reeves station, potash plant of the R. S. Ryan Co. at, plate showing..... 80 Richman, William, record of well of........ 38 Ridgway, Richard, record of well of........ 82 Ryan, R. S., Co., marl pit of............. 80-81 marl pit of, exposure at, plate showing. . $\quad 80$ potash plant of, at Reeves station, plate showing...................... 80 process developed by ................. 109

$\mathrm{s}$.

Salem to Blackwood, geologic map of area

In pocket.

Salem district, exposures of marl in......... 27

lime and lime sand in................ 28

records of holes in. ..................... 21-23

records of wells in.................... 24-27

selection of sites in.................... 21

thickness and potash content of marl beds in .......................... 104

tonnage and value of marl in............ 29

utilization of deposits in............... $\quad 29$

Salem Water Co., record of well of........... 27

Salina, record of well near............... $\quad 54$

Samples, for mechanical analysis, preparation of....................... 106

methods of taking, in drill holes........ 16-18 "Sand-marl".......................... 10 Schmidt, John, record of well of........... 54 Scope of the investigation. ................ 1-2 Sea Girt, record of well at............. 101-102 Sedimentation, conditions of .............. 137-138 Separation, magnetic, of greensand....... 118-119 wet, of greensand ................... 116-118 of greensand, composition of products of $\ldots . . . . .125$

Sewell district, lime sand in............... 57,60 records of holes in . . . . . . . . . . . . . . . . records of wells in................... 52-56 sites included in .................... 42 thickness and potash content of marl beds in......................... 104 tonnage and value of marl in........... $57-58$ utilization of deposits in............... 58 "Sewell marl"......................... 11 Sewell marl pit. See West Jersey Marl \& Transportation Co.

Shark River marl, features of............. 12 Sharptown, records of wells at.............. 38,39 Shreve, R. Morris, cited............... 108 Shutes, John, record of well of ............. 43 Sites for drilling, selection of.............. 14-15 
Size of grains in greensand ............... 119-122

Soil, sandy, improvement in texture of, by adding clayey greensand......... 115

Somerdale district, exposures in marl pits in. 66-67

lime sand in.

records of holes in.

67

records of wells in

$60-65$

selection of site in

$65-66$

thickness and potash content of marl

beds in ...............

104

utilization of deposits.................. $\quad 67$

Squankum marl pits, location of........... $\quad 98$

Stokes, J. W., record of well of.............. 79

Stratford House, record of well at........... 65

Stratigraphic comparisons of borings, plate showing....................... 134

Stratigraphic features of the greensand beds 135-137 Streams, quality of marl along.............. 13-14

Strike of greensand beds................... 6

Structure of the deposits.................. 13-14

Sykesville, marl near.

T.

Taylor, Samuel J., drilling contract made with..........................

Thickness of greensand beds............... 6

Transportation, facilities for............... 4-5

Trenton, section of formations southeast of, plate showing. ................ 12

True, R. H., and Geise, F. W., experiments of, with greensand as a fertilizer 113-114

Twitchell, M. W., cited. $35-36,36-37$

\section{V.}

Vincentown, lime sand near. $84-85$

marl pits near....................... 83-84

records of wells near............... 81-83,105

Vincentown Marl Co., pits of................ 84

Vincentown sand, description of. w.

Page.

Washing of greensand, method and results

of........................... 116-118

Water, in marl, partial analyses of........ 132-133

Waverly Chemical Co., hydrated carbonate of potash produced by.......... 107

Weight, determination of................ 19-20

Well data, collection of ................... 20

Wenonah sand, description of............ 9-10

West Jersey Marl \& Transportation Co., pit of, plate showing............... 76

records of borings made by........... 51

records of holes on property of .......... 47-50

pit of, section in ..................... 51-52

White, Barclay, record of well of. . ......... 90

Wills, J. S., record of well of............... 79

Wills, T. R., record of well of.............. $\quad 74$

Winslow, record of well at.................. 68

Woodbury, location of wells of............. 54

record of test well drilled for............ 54

Woodbury clay, description of............ 8 8-9

Woodstown, wells for public water supply of. 35-36

Woodstown district, drilling operations in, plate showing................. 16

exposures of marl in .................. 39

lime sand in ......................... 39-40

records of holes in . ................... 31-34

records of wells in ...................... $34-39$

selection of site in.................... 30

thickness and potash content of marl beds in.......................... 104

tonnage and value of marl in.......... 40

utilization of deposits in............... 41

Woodstown Ice \& Cold Storage Co., record of well of......................... 37

Wrightstown, $\operatorname{marl}$ at................... 91-92

Y.

Young's pier, Atlantic City, record of deep well at. 